UNIVERSIDADE DE SĀO PAULO

INSTITUTO DE GEOCIENCIAS

\title{
AVALIAÇÃO HIDROGEOLÓGICA E HIDROGEOQUÍMICA DAS ÁGUAS SUBTERRÂNEAS DE CUBA CENTRO-ORIENTAL COM ÊNFASE NAS ÁGUAS MINERAIS
}

\author{
José Antonio Valdés González
}

\author{
Orientador: Prof. Dr. Uriel Duarte
}

TESE DE DOUTORAMENTO

Programa de Pós-Graduação em Recursos Minerais e Hidrogeologia

\author{
SÃO PAULO \\ 2001
}




\section{UNIVERSIDADE DE SÃO PAULO \\ INSTITUTO DE GEOCIÊNCIAS}

\section{AVALIAÇÃO HIDROGEOLÓGICA E HIDROGEOQUIIMICA DAS ÁGUAS SUBTERRÂNEAS DE CUBA CENTRO-ORIENTAL COM ÊNFASE NAS ÁGUAS MINERAIS}

JOSÉ ANTONIO VALDÉS GONZÁLEZ

Orientador: Prof. Dr. Uriel Duarte

TESE DE DOUTORAMENTO

COMISSÃO JULGADORA

Nome

Presidente: Prof. Dr. Uriel Duarte

Examinadores: Prof. Dr. Aldo da Cunha Rebouças

Prof. Dr. André Celligoi

Prof. Dr. Chang Hung Kiang

Dr. Hélio Nóbile Diniz

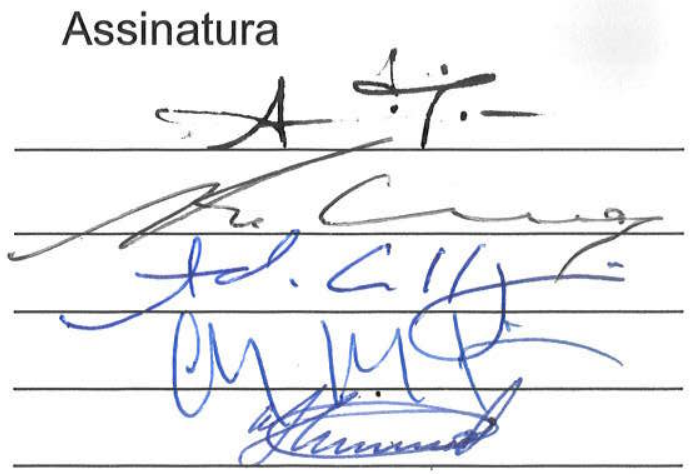

SÃO PAULO

2001 


\section{UNIVERSIDADE DE SÃO PAULO \\ INSTITUTO DE GEOCIÊNCIAS}

\section{AVALIAÇÃO HIDROGEOLÓGICA E HIDROGEOQUIIMICA DAS ÁGUAS SUBTERRÂNEAS DE CUBA CENTRO-ORIENTAL COM ÊNFASE NAS ÁGUAS MINERAIS}

José Antonio Valdés González

Orientador: Prof. Dr. Uriel Duarte

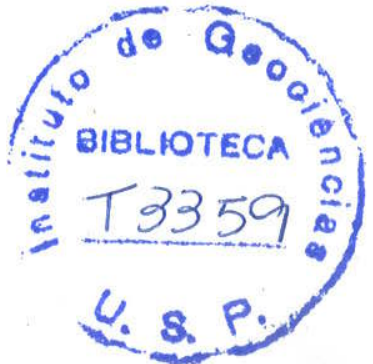

TESE DE DOUTORAMENTO

Programa de Pós-graduação em Recursos Minerais e Hidrogeologia

São Paulo

2001

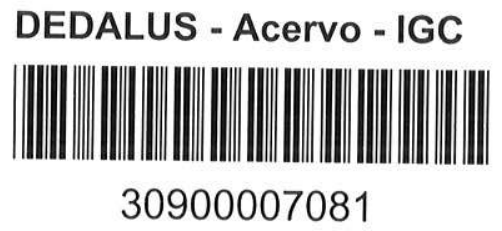


Esta Tese de Doutorado foi realizada com o apoio e financiamento da FAPESP

Processo 94/03224-4 
A minha esposa, Alejandra Torrens Girón e nossos filhos, Tais e Tarik. 


\section{AGRADECIMENTOS}

Resulta impossível, após de transcorrido cinco anos longe do país de origem, acabar uma obra sem considerar a participação ativa, técnica e socialmente, de inúmeras pessoas que proporcionaram o estímulo e fé para chegar à meta final.

Ainda que dificultoso pudesse ser ordenar os agradecimentos àqueles que me ajudaram começar e concluir esta pesquisa, devo, de algum jeito, hierarquizarlos por aspetos fundamentais de participação.

Agradeço chegar à apresentação da minha Tese:

-A Alejandra Torrens Girón que soube, apesar da distância em tempo e espaço, me transmitir à suficiente confiança, compreensão e estimulação que me permitiu a necessária concentração no meu trabalho. Devo a ela, pelas mesmas considerações, qualquer sucesso na minha vida profissional e pessoal.

-A Uriel Duarte, meu orientador, que pese que me acolheu em circunstâncias estressantes, soube me dedicar, com alto profissionalismo e grande simplicidade, seus esforços e conhecimentos para alcançar o fim desta pesquisa.

-A Marcelo da Rocha, a quem tantas vezes auxiliou-me em consultas de toda índole, e cuja atenção para mim foi maior que para um amigo, foi a atenção de um irmão.

-Ao pessoal da pós-graduação do Instituto de Geociências que me suportaram tantas queixas e papos.

-Aos trabalhadores do Instituto de Geociências, em particular os professores Lilian Sant'Agostino e Claudio Riccomini e Ana Paula, da Secretaria de PósGraduação, assim como demais professores, pessoal administrativo e de serviços, que nunca me limitaram a ajuda solicitada.

-Ao povo brasileiro, que me acolheu no seu seio como mais um filho, permitindome reduzir a normal nostalgia de quem mora tanto tempo longe da sua família e amigos, abrindo-me as portas da sua alma.

-Aos colegas cubanos residentes em Brasil, em especial os provenientes do Instituto de Geologia e Paleontologia de Cuba.

-A todos aqueles não mencionados que justamente consideram que contribuíram neste trabalho parcial ou totalmente, pouco ou muito, em Cuba ou Brasil, peço-lhes desculpas por esquece-los no presente momento desta redação. O resultante anonimato de todos os que me ajudaram, mais do que se pode contar, é circunstancial quanto ao documento, mas meu agradecimento será eterno quanto a meu coração. 


\section{RESUMO}

Esta pesquisa foi desenvolvida na llha de Cuba, situada à entrada do Golfo de México, ao sul do Trópico de Câncer. No território cubano, selecionou-se a área Cuba Centro-Oriental, com uma extensão de $27000 \mathrm{Km}^{2}$, que representa $24 \%$ de toda a área do país.

O alvo principal desta pesquisa foi estudar a evolução do quimismo das águas subterrâneas do território selecionado, para conhecimento das condições que contribuiriam na gênese das águas minerais existentes no território e assim poder prognosticar as possibilidades de prospeção e exploração de um ou outro tipo hidrogeoquímico específico, com base em 5000 pontos hidrogeológicos de informação pré-existente e amostras de campo das principais fontes de águas minerais da região de estudo.

O enfoque inicial e a aplicação conseqüente dos aspectos avaliados, permitiram destacar e fundamentar a existência de um processo relacionado com o aumento constante da concentração do cloreto nas águas subterrâneas, que denominamos de Cloretogênese, e de cujo processo foi deduzida uma expressão estatística nova para calcular a idade das águas subterrâneas:

\section{$\mathrm{T}=0,0015[\mathrm{Cl}]$}

\section{Idade das águas subterrâneas $(\mathrm{Ma})=0,0015$ [Concentração do ânion cloreto (mg/L)]}

Os resultados apresentam, do ponto de vista da análise hidrogeoquímica, uma interpretação dos mecanismos da circulação das águas subterrâneas, diferente da tradicional, expressa no Modelo Hidrogeoquímico do fluxo subterrâneo de Cuba Centro-Oriental, podendo ser aplicada no:

-Desenvolvimento de programas e técnicas de pesquisa hidrogeoquímicas para a obtenção de informação sobre as generalidades e particularidades da constituição e distribuição das águas subterrâneas com a finalidade de caracterizar o seu processo de formação, e

-Investigação de associações entre a geologia da área de estudo e os modos de ocorrência das águas tendo em vista o estabelecimento de analogias úteis às áreas de pouca ou nenhuma informação hidrogeológica. 


\section{SUMMARY}

This research was developed on the Island of Cuba, located at the entrance of the Golf of Mexico, south of the Tropic of Cancer. In the Cuban territory, the Cuba Centro-Oriental area was selected, with an extension of $27,000 \mathrm{Km} 2$ and represents $24 \%$ of the entire country.

The main objective of this research was a groundwater chemical evolution study of the selected territory in order to know the conditions that would contribute to the geneses particularities of the existing mineral waters, and in this way, to be able to forecast the prospecting and exploitation possibilities of any hydrogeochemical specific water type. For this purpose, more than 5,000 hydrogeological database points were processed, and the mineral waters main sources in the study area were sampled.

The initial approach and the resulting application of each assessed aspect, pointed out and argued the existence of a natural process related to the constant increase of the chloride concentration in the groundwater, which was named Cloretogenese, and from its process a new statistical expression for estimating the groundwater's age was created:

$$
T=0,0015[\mathrm{Cl}]
$$

\section{Groundwater age $(\mathrm{Ma})=0,0015$ [Chloride anion Concentration $(\mathrm{mg} / \mathrm{L})]$}

From the hydrogeochemical point of view, the results represent an interpretation of the groundwater circulation mechanisms that differs from the traditional one, and reliably expressed in the Center-Oriental Cuba groundwater flow Hydrogeochemical Model proposed, which could be applied in the:

-Development of hydrogeochemical research software and techniques in order to obtain information about, both, generalities and particularities of the groundwater's constitution and distribution to characterize its formation process, and

-Investigation of geological associations with groundwater hydrogeochemical type presentation in the study area, established useful analogies to those areas of both, little or none hydrogeological information. 


\section{INDICE ANALÍTICO}

1 INTRODUÇÃO 1

II OBJETIVOS -.- 4

III PESQUISA BIBLIOGRÁFICA 5

1. Recursos Hidricos Termais e Minerais em geral-_______-_._- 5

2. Águas Termais e Minerais em Cuba em geral--_-_-_------ 8

3. Antecedentes documentais sobre as ocorrências das Águas Termais e Minerais na Área de Estudo. - -

4. Metodologia Hidrogeológica e Hidrogeoquímica--_-_-_-_--- 16

4.1 Generalidades sobre a aplicação do Método Hidrogeoquímico ----------- 17

4.2. Cartografía Hidrogeoquímica--- 18

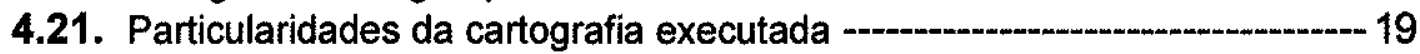

4.3. As técnicas de processamentos---_o

5. Considerações hidrogeológicas e hidrogeoquímicas-_-_-_-_-_-23

5.1 O sistema hidrogeológico das águas minerais-- 24

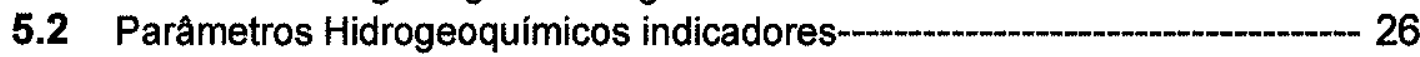

5.3 Consideraç⿸̃es geológicas-n-2

IV ÁREA DE ESTUDO-31

4.1. Area de Estudo Sensu Lato-_-_ 34

4.1.1. Aspectos Geográficos --- 34

4.2. Área de Estudo Sensu Stricto (Cuba Centro-Oriental)--_-_-_-_- 36

4.2.1 Geologia --_-36

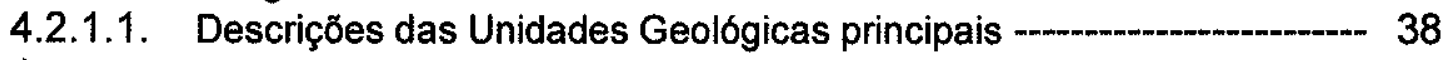

$1 . \quad$ A Faixa Dobrada -- 38

1.1. Unidades Continentais - - 38

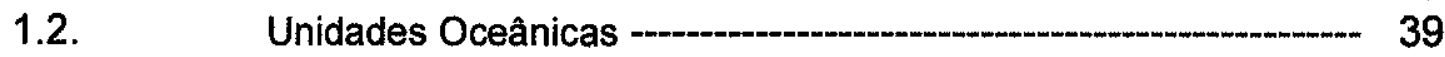

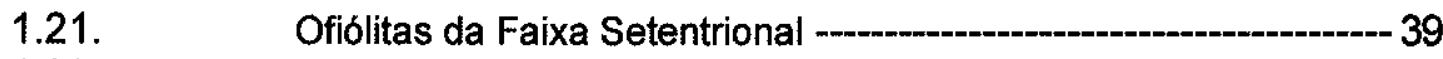

1.22. Arco Vulcânico do Cretáceo -..- 41

1.23. Complexos Plutônicos e Metamórficos -.._-_-_- 41

2. Neoautôctone (Cobertura Cenozoica) - - $\quad 43$

2.1. Paleogêno -

2.2. Neogéno - 21.

2.3. Quaternário - - 44

4.2.2 Aspectos tectônicos -...- 51

4.2.3 Recursos minerais -..._._. 52

4.2.4 Geomorfologia - - 53

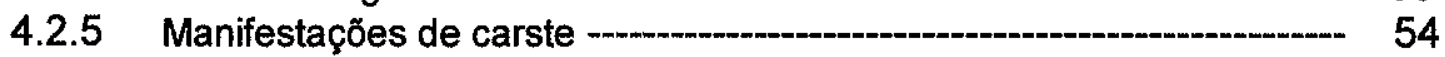

4.2.6 Precipitaçôes --

4.2.7 Escoamento superficial - -

4.2.8 Hidrogeologia -

4.2.8.1. Descriçóes das capacidades aqüiferas dos 63

4.2.8.2. Algumas particularidades da hidrogeologia cubana ---a-a-- 67

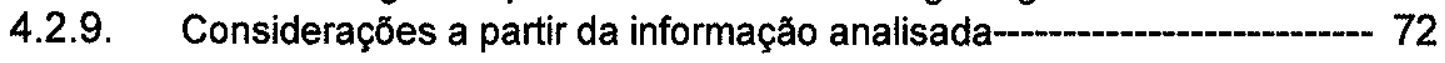


1. Metodologia de Campo. Amostragem --..- 76

2. Procedimento de Análise Utilizados em Laboratório -.-_-_-_-_-_- 78

3. Processamento da informação utilizada -- 78

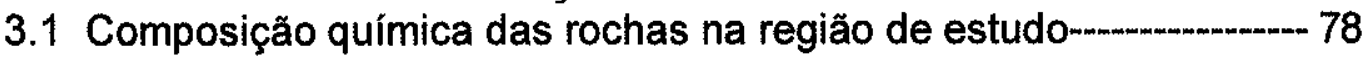

3.2 Cadastramento das águas subterrâneas da região ----.--.--.-- 81

3.3 Considerações sobre a representatividade dos resultados-..--.-- 82

VI. CAMPANHA DE AMOSTRAGEM - 85

1. Amostragem --_o 85

2. Descrição dos pontos amostrados --

VII. RESULTADOS E DISCUSSÃO

1. Identificação das correspondências entre o quimismo das rochas e as águas subterrâneas, aplicando comparativamente os diagramas triangulares e gráficos semilogarítmicos para um universo similar dos componentes químicos

1.1. Caracterização química geral das rochas da região de estudo ---------97

1.2. Caracterização química específica das rochas e as

suas águas subterrâneas

2.Classificação dos tipos hidroquímicos das águas subterrâneas associadas aos conjuntos litológicos da sua circulação

3. Estabelecimento da correspondência da dissociação dos componentes aniônicos principais com a concentração da solução para cada tipo hidrogeoquímico determinado

3.1. Outras considerações da dissociação dos ânions

4. Avaliação dos limites da estabilidade das correspondências avaliadas para o prognóstico do comportamento das águas a concentrações acima das águas subterrâneas comuns

4.1. Conclusóes parciais no que diz ao respeito 140

5.Considerações derivadas do processo da cloretogênese.

Fundamentação de um novo método de datação de idades das águas-143 6.Outras considerações necessárias ao Método da Concentração do Cloreto

6.1. Comparação com o uso de outros componentes

6.2. O processo da Cloretogênese e o Método da Concentração do Cloreto

7.Aplicação do Método da Concentração do Cloreto à Interpretação hidrogeológica da região de estudo $-156$

7.1. Interpretação da análise às manifestações na superfície 163

8. Considerações sobre as águas minerais cubanas, em particular de Cuba Centro-Oriental, $e$ as relacionadas com as jazidas de petróleo na região de estudo

9. Modelo hidrogeoquímico de fluxo $-186$ 
10. Conclusões e Recomendações

1. Relação rocha/água subterrânea

2. Correlação das condutividades com as concentrações aniônicas das águas subterrâneas

3. Derivações gerais a partir das análises químicos na literatura internacional especializada da evolução dos cloretos nas águas subterrâneas quando alcançam valores extremos da concentração

4. Hidrogeoquímica da região de estudo--_-_-199

5. Recomendações ---o---201

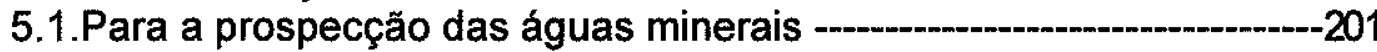

5.2. Para a avaliação da exploração das águas minerais----_-_---202

VIII. REFERÊNCIAS BIBLIOGRÁFICAS - 


\section{INDICE DE FIGURAS}

Figura 1 Localização geográfica da República de Cuba.---_-_-_-_-_----31

Figura 2 Divisão Política da República de Cuba --_-32

Figura 3 Distribuição das Zonas de Plataformas pertencentes às unidades continentais relacionadas com Cuba …-...- 34

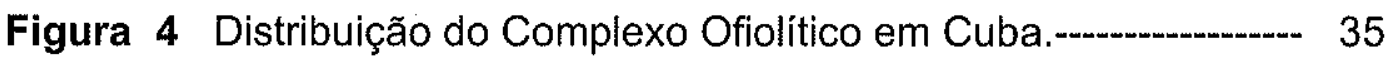

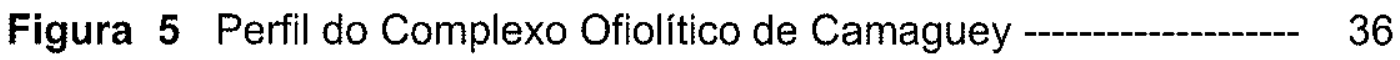

Figura 6 Esquema da distribuição dos complexos intrusivos na área de estudo (Cuba Centro-Oriental) -....-...-...-...- 38

Figura 7 Mapa geológico da área de estudo, Cuba Centro-Oriental--- 41

Figura 8 Apresentação dos grupos estruturais segundo a distribuição das idades dos conjuntos de formações geológicas ---------43

Figura 9 Mapa Geológico da Província Ciego de Ávila -ב-_-_-_-_-_- 44

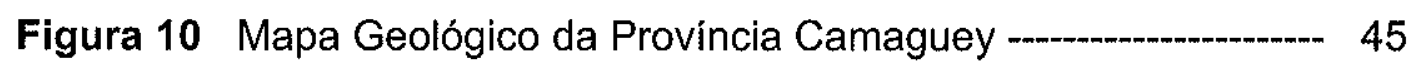

Figura 11 Mapa Geológico da Província Las Tunas -.._-_._._. 46

Figura 12 Esquema das principais configurações tectônicas da área de estudo -

Figura 13 Mapa dos tipos de jazidas existentes na Área de Estudo ----49

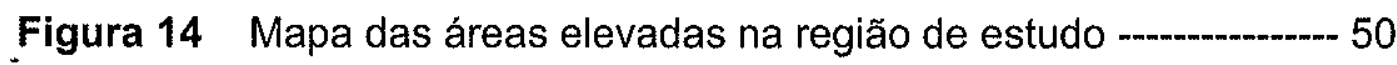

Figura 15 Mapas das diferentes manifestações cársticas na área de estudo

Figura 16 Distribuição das precipitações médias anuais em Cuba com ênfase para a Área de Estudo - 52

Figura 17 Distribuição dos rios existentes na área de estudo -..--..-- 53

Figura 18 Barragens construídas na província de Ciego de Ávila--_-_-_-56

Figura 19 Barragens construídas na província de Camaguey.----------56

Figura 20 Barragens construídas na província de Las Tunas. ---------- 57 
Figura 21 Mapa Hidrogeológico da área de estudo, apresentando as suas principais características

Figura 22 Perfil hidrogeológico esquemático da área de estudo -------- 63

Figura 23 Esquema construtivo típico de um poço em um aqüífero cárstico

Figura 24 Exemplo esquematizado da construção de o poço de exploração de Peña Azul, Camaguey $-65$

Figura 25 Esquema representativo das condicionantes hidrogeológicas da região de estudo, com base nas informações gerais existentes.

Figura 26 Esquema generalizando um possível limite à exploração das águas minerais na região de estudo que, se ultrapassado, pode influir negativamente na qualidade da sua composição química.

Figura 27 Localização das fontes de águas minerais amostradas---.---- 71

Figura 28 Localização das fontes pertencentes à província de Ciego de Ávila

Figura 29 Localização das fontes pertencentes à província de Camaguey

Figura 30 Localização das fontes pertencentes à província de Las Tunas

Figura 31 Gráficos apresentando as características gerais da composição química das rochas representadas na região de estudo

Figura 32 Gráficos que comparam a composição química das rochas origem e das águas subterrâneas que circulam pelos serpentinitos e peridotitos de Camaguey

Figura 33 Gráficos relacionados com as características da composição química das rochas ígneas intrusivas representadas na região de estudo

Figura 34 Gráficos que comparam a composição química das rochas origem e das águas subterrâneas que circulam pelos granitos de Camaguey.

Figura 35 Gráficos que comparam a composição química das rochas origem e das águas subterrâneas que circulam pelos granodioritos de Camaguey e Las Tunas 
Figura 36 Gráficos relacionados com as características da composição química das rochas vulcânicas representadas na região de estudo

Figura 37 Gráficos que comparam a composição química das rochas origem e das águas subterrâneas que circulam pelas formações geológicas Contramaestre e Caobillas

Figura 38 Gráficos que comparam a composição química das rochas origem e das águas subterrâneas que circulam pela Formação Guines de Ciego de Avila e os calcários de Camaguey --- 104

Figura 39 Gráficos que comparam a composição química das rochas origem e das águas subterrâneas que circulam pela Formação Vertientes e Vila Roja

Figura 40 Apresentação nos diagramas de Piper das classificações características representativas das águas subterrâneas que circulam pelos diferentes conjuntos litológicos analisados

Figura 41 Resumo das classificações dos tipos de águas que circulam pelos diferentes meios litológicos a partir da esquematização do conjunto de linhas do Diagrama Semilogarítmico de Schoeller.

Figura 42 Correlação gráfica dos componentes aniônicos principais em meq $/ \mathrm{L} \mathrm{com}$ respeito à Condutividade em $\mu \mathrm{S} / \mathrm{cm}$ nas águas subterrâneas que circulam através dos serpentinitos e peridotitos

Figura 43 Correlação gráfica dos componentes aniônicos principais $\mathrm{em} \mathrm{meq} / \mathrm{L}$ com respeito à Condutividade $\mathrm{em} \mu \mathrm{S} / \mathrm{cm}$ nas águas subterrâneas que circulam através dos granitos de Camaguey

Figura 44 Correlação gráfica dos componentes aniónicos principais $\mathrm{em} \mathrm{meq} / \mathrm{L} \mathrm{com}$ respeito à Condutividade $\mathrm{em} \mu \mathrm{S} / \mathrm{cm}$ nas águas subterrâneas que circulam através dos granodioritos de Camaguey.------ 116

Figura 45 Correlação gráfica dos componentes aniônicos principais $\mathrm{em} \mathrm{meq} / \mathrm{L}$ com respeito à Condutividade $\mathrm{em} \mu \mathrm{S} / \mathrm{cm}^{2}$ nas águas subterrâneas que circulam através dos granodioritos de Las Tunas

Figura 46 Correlação gráfica dos componentes aniônicos principais $\mathrm{em} \mathrm{meq} / \mathrm{L} \mathrm{com}$ respeito à Condutividade em $\mu \mathrm{S} / \mathrm{cm}$ nas águas subterrâneas que circulam através da Formação Contramaestre

Figura 47 Correlação gráfica dos componentes aniônicos principais $\mathrm{em} \mathrm{meq} / \mathrm{L}$ com respeito à Condutividade em $\mu \mathrm{S} / \mathrm{cm}$ nas águas subterrâneas que circulam através da Formação Caobillas 
Figura 48 Correlação gráfica dos componentes aniónicos principais $\mathrm{em}$ meq/L com respeito a Condutividade em $\mu \mathrm{S} / \mathrm{cm}$ nas águas subterrâneas que circulam através da Formação Vertientes 120

Figura 49 Correlação gráfica dos componentes aniónicos principais em $\mathrm{meq} / \mathrm{L}$ com respeito à Condutividade em $\mu \mathrm{S} / \mathrm{cm}$ nas águas subterrâneas que circulam através da Formação Guines de Ciego de Ávila -122

Figura 50 Comparação das similaridades das tendências lineares da correspondência Condutividade $(\mu \mathrm{S} / \mathrm{cm}) /$ Cloretos (meq/L) para os conjuntos litológicos analisados

Figura 51 Gráficos que apresentam o comportamento dos componentes principais de uma seleção das águas subterrâneas salgadas de Israel. Relacionam-se neles a concentração das precipitações particulares do território

Figura 52. Gráficos que apresentam o comportamento dos componentes principais de uma seleção das águas subterrâneas de alta salinidade

Figura 53 Gráficos que apresentam o comportamento dos componentes principais de uma seleção das águas de salmouras relacionadas com depósitos de petróleo

Figura 54 Gráficos que apresentam o comportamento dos componentes principais de uma seleção das águas vinculadas com jazidas de petróleo

Figura 55 Gráficos que resumem a análise do comportamento dos ânions nas águas de alta salinidade

Figura 56 Relação das concentrações de cloretos em águas vinculadas com litologias de idades estratigráficas conhecidas

Figura 57 Gráficos que relacionam a concentração do ânion cloreto $(\mathrm{mg} / \mathrm{L})$ das águas subterrâneas com os valores das idade estratigráficas (em milhões de anos) das litologias pelas quais circulam ----

Figura 58 Correlação calculada pelo Programa EXCEL entre o Tempo Geológico em milhões de anos (eixo y) e a concentração do ânion Cloreto em $\mathrm{mg} / \mathrm{L}$ (eixo $\mathrm{x}$ ) nas águas altamente salinizadas e estratigraficamente datadas

Figura 59 Gráficos comparativos das tendências dos erros entre os Métodos de ${ }^{36} \mathrm{Cl}$ e Hidrodinâmico com o Método da Concentração do Cloreto (MCC) onde se aprecia que os erros diminuem para as idades superiores aos milhões de anos 
Figura 60 Valores do ânion cloreto nos correspondentes histogramas-----149

Figura 61 Histogramas do conteúdo de cloreto das águas subterrâneas provenientes dos principais conjuntos litológicos analisados na região de estudo

Figura 62 Representação gráfica da distribuição das idades das águas subterrâneas que circulam pelos diferentes conjuntos litológicos da região de estudo

Figura 63 Distribuição territorial das formações geológicas selecionadas na área de estudo

Figura 64 Argumentação dos limites de cloretos utilizados na análise da sua distribuição espacial nas águas subterrâneas que circulam pelas formações geológicas selecionadas

Figura 65 Distribuição dos cloretos nas águas subterrâneas que circulam pelo Complexo Ofiolitico na região de estudo

Figura 66 Distribuição dos cloretos nas águas subterrâneas que circulam pela Formação Caobillas na região de estudo

Figura 67 Detalhe da distribuição dos cloretos nas águas subterrâneas que circulam pela Formação Guines na região de estudo $\quad---160$

Figura 68 Interpretação das configurações apresentadas pela distribuição das concentrações dos cloretos nas formações geológicas processadas

Figura 69 Diagrama de Piper e Correlação gráfica da concentração dos cloretos com os Sólidos Totais Dissolvidos (STD) das águas minerais medicinais de Cuba e das águas salinizadas provenientes das jazidas de petróleo da região de estudo

Figura 70 Gráfico de correlação CI/STD especificamente para os tipos de águas minerais reportados na região de estudo

Figura 71 Representação gráfica da relação de idades dos mananciais de águas minerais com as idades das águas subterrâneas que circulam pelas litologias correspondente reportadas nos respectivos estudos hidrogeológicos

Figura 72 Distribuição no território dos poços de águas minerais medicinais e dos poços de petróleo relacionados com a jazida petrolífera Pina da parte ocidental da região de estudo 
Figura 73 Mapas comparando as diferentes distribuições das concentrações do cloreto para os casos de: A (os valores para os pontos medidos na superfície do terreno) e B (os valores para os pontos medidos nas profundidades nos poços das jazidas de petróleo) ------173

Figura 74 Representação em relevo da distribuição das concentrações dos cloretos separados nos dois diferentes níveis de profundidades processados

Figura 75 Comparação da distribuição das concentrações dos cloretos das águas subterrâneas das formações dos ofiolitos, Caobillas e Guines no mapa geológico utilizado com o esquema tectônico de blocos estruturais da região de estudo

Figura 76 Montagem em perspectiva da generalização do mapa geológico $\left(10^{\circ}\right.$ na horizontal) e o seu perfil correspondente NE - SE da região de estudo

Figura 77 Esquema da interpretação no perfil NE - SW da distribuição dos tipos aniônicos das águas subterrâneas, atendendo a seus teores de cloretos.

Figura 78 Mapa da distribuição aniônica das águas subterrâneas de Cuba Centro Oriental

Figura 79 Perfil da distribuição das idades em milhões de anos e referenciadas com as idades estratigráficas

Figura 80 Mapa da distribuição das idades das águas subterrâneas de Cuba Centro Oriental

Figura 81 Representação do modelo hidrogeoquímico de fluxo subterrâneo, do ponto de vista da distribuição aniônica e da distribuição das idades das águas subterrâneas da região Cuba Centro Oriental 


\section{INDICE DE TABELAS}

TABELA 1. COMPARAÇÃO ENTRE OS REQUERIMENTOS

PARA AS ÁGUAS MINERAIS EM 1987 E EM 1995

TABELA 2. RELAÇÃO DAS TEMPERATURAS DAS AGUAS MINERAIS DE CUBA.

TABELA 3 . RELAÇÃO DA DENSIDADE DE TRABALHO CONSEGUIDAS EM PESQUISAS HIDROGEOQUIIMICAS

TABELA 4. DADOS TÉCNICOS DAS BARRAGENS CONSTRUIIDAS NA REGIÃO DE ESTUDO. $-58$

TABELA 5. EXEMPLOS DA VARIAÇÃO DOS VALORES DA VAZÃO ESPECÍFICA (q) EM DIFERENTES FORMAÇÕES GEOLÓGICAS DA ÁREA DE ESTUDO

TABELA 6 . RESUMO DA ANÁLISE DA COMPOSIÇÃO QUIMICA DOS TIPOS LITOLÓGICOS SELECIONADOS NA REGIÃO DE ESTUDO E DA CLASSIFICAÇÃO DAS ÁGUAS SUBTERRÂNEAS NELES CONTIDAS

TABELA 7 RESULTADOS DAS CORRELAÇÕES ENTRE A CONDUTIVIDADE ELÉTRICA E CL', $\mathrm{SO}_{4}{ }^{2}, \mathrm{HCO}_{3}{ }^{-} \mathrm{E}$ STD DAS ÁGUAS SUBTERRÂNEAS NA ÁREA DE ESTUDO, CUBA CENTRO-ORIENTAL

TABELA 8 REFERENCIAS BIBLIOGRÁFICAS DAS FONTES DOS DADOS UTILIZADOS NAS FIGURAS CORRESPONDENTES 134

TABELA 9 COMPARAÇÃO DAS IDADES DAS ÁGUAS ATRAVÉS DOS MÉTODOS ATUAIS COM O MÉTODO DA CONCENTRAÇÃO DE CLORETO 151

TABELA 10 COMPARAÇÃO DAS IDADES DAS AGUAS ATRAVÉS DE MÉTODOS ATUAIS COM O MÉTODO DA CONCENTRAÇÃO DE CLORETO 154

TABELA 11 IDADES DAS ÁGUAS SUBTERRÂNEAS QUE CIRCULAM NOS CONJUNTOS LITOLÓGICOS DA REGIÃO DE ESTUDO CUBA CENTRO ORIENTAL (MÉTODO DA CONCENTRAÇÃO DE CLORETO) 161 
TABELA 12 IDADES DAS ÁGUAS MINERAIS MEDICINAIS CUBANAS CALCULADAS PELO MÉTODO DE CONCENTRAÇÃO DE CLORETO EM MILHÕES DE ANOS COM A SUA EQUIVALEENCIA NAS IDADES ESTRATIGRÁFICAS

TABELA 13 IDADES DAS ÁGUAS SUBTERRÂNEAS

ALTAMENTE SALINIZADAS RELACIONADAS COM AS JAZIDAS

CUBANAS DE PETRÓLEO, CALCULADAS PELO MÉTODO

DE CONCENTRAÇÃO DE CLORETO EM MILHÕES DE ANOS COM A

SUA EQUIVALÊNCIA NAS IDADES ESTRATIGRÁFICAS

\section{INDICE DE ANEXOS}

ANEXO I. NORMAS CUBANAS DE ÁGUAS MINERAIS

ANEXO II. GENERALIDADES SOBRE A MEDICINALIDADE DAS ÁGUAS MINERAIS 


\section{INTRODUÇÃO}

As águas minerais e termais são águas subterrâneas cuja composição físicoquímica e bacteriológica outorgam-lhe propriedades especificas favoráveis, principalmente à saúde humana, e para outros usos relacionados com a indústria, seja pela sua temperatura ou pela concentração particular dos seus componentes úteis. A contribuição que a exploração das águas minerais aportam à economia dos países, unido à dependência das suas benéficas composições às particularidades da geologia dos territórios onde se apresentam, deram-lhe o caracter de recurso nacional, similar ao caracter que tem para as economias nacionais, os minerais sólidos e petróleo. Esta consideração de recurso hidromineral, assim chamado para destacar a sua dupla condicionalidade de ser água e ter uma composição mineral útil, fundamenta a legalização, exploração e controle das suas jazidas por entidades geológicas governamentais. Contraditoriamente, o grau de conhecimento das riquezas e potencialidades dos recursos hidrominerais não é tão similar quanto os demais recursos minerais. Nos países de maior tradição e cultura de exploração das águas minerais, como são os países europeus, o grau de estudo nacional das águas minerais é inferior se comparado com o grau de estudo nacional dos restantes recursos minerais, em especial, metais, carvão e petróleo. As atuais discussões hidrogeológicas sobre o uso dos termos reservas ou recursos para as quantidades exploráveis das águas subterrâneas não tem chegado às águas minerais. Ao contrário, o conhecimento das propriedades medicinais, o aproveitamento, aplicação e controle sanitário das águas minerais supera o conhecimento hidrogeológico das águas minerais dos referidos países.

O conhecimento das particularidades de algumas jazidas de águas minerais em regiões específicas, fundamentou o grau de complexidade máxima que possuem estas águas em pesquisas sobre a sua gênese e circulação. A complexidade hidrogeológica evidenciou a necessidade de maiores investimentos nestas pesquisas e de diferenciá-las das economias das explorações das restantes águas subterrâneas. A maioria dos estudos regionais dedicado para esse fim partiu de contornar o seu quimismo "especial" dentro do contexto hidrogeológico, mas não analisar a evolução particular das águas minerais dentro o processo geral do quimismo das águas subterrâneas. Os resultados de tais estudos apenas podiam concluir na existência de áreas com diferentes tipos de águas, explicadas a partir da distribuição dos tipos litológicos, mas não completadas nas explicações das transformações possiveis entre uns e outros tipos hidrominerais.

Algumas concentrações anômalas foram justificadas em alguns estudos regionais através da possível existência de águas conatas (envelhecidas e concentradas junto à formação dos sedimentos) ou juvenis (mineralizadas a partir das emanações magmáticas), desprezando para interpretar tais anomalias, a argumentação que as relacionam com a insuficiência de informação existente utilizada. 
A Hipótese geral que guiou o presente trabalho se deu a partir das seguintes concepções: 1) As águas minerais são águas subterrâneas que respondem às particularidades dos mesmos processos que enriquecem as mesmas águas do sob solo. Não existe água particular, existem particularidades dos mesmos processos. 2) Os resultados do tratamento hidrogeoquímico conjunto das águas subterrâneas destacará a existência, comportamento e distribuição das águas minerais como anomalias da região.

Por isso, o alvo principal desta pesquisa foi estudar a evolução do quimismo das águas subterrâneas do território selecionado para precisar as condições que contribuiriam às particularidades das gêneses das águas minerais existentes no território e assim poder prognosticar as possibilidades de prospeção e exploração de um ou outro tipo específico.

Os resultados obtidos neste estudo, nos permitiram:

\section{a)-Do ponto de vista científico}

1. Elevar o nivel de estudo da região sob análise

2. Estabelecer as associações águas subterrâneas/rochas existentes.

3. Contribuir ao esclarecimento dos mecanismos de constituição das águas subterrâneas em geral e das águas minerais em particular.

4. Conhecer as potencialidades existentes no território para conseguir um tipo determinado de água subterrânea.

5. Estabelecer os aspetos mais relevantes que permitam identificar a existência de um determinado tipo de água mineral.

6. Obter um mapa que apresente a distribuição das potencialidades dos recursos hidrominerais da região.

7. Estabelecer uma metodologia de análise hidrogeoquimica que possibilite aplicá-las às restantes regiões do país e de outros paises com condições similares.

\section{b)-Do ponto de vista econômico}

1. Eliminar investimentos em áreas poucos promissoras.

2. Reduzir investimentos nas áreas promissoras.

3. Indicar investimentos segundo as particularidades da prospeção nas áreas selecionadas.

4. Avaliar as potencialidades hidrominerais existentes para os fins do planejamento e exploração relacionados com a saúde pública, a industria e o turismo nacional e internacional.

5. Argumentar as possibilidades e factibilidades de estender estudos similares às restantes regiões do país para equilibrar nacionalmente o grau do conhecimento dos recursos hidrominerais.

Para abordar este assunto, foi selecionada a llha de Cuba, situada à entrada do Golfo de México, ao sul do Trópico de Câncer, entre a América do Norte e América do Sul. Cuba é um território que começa a sua história geológica a partir dos finais do período Jurássico e, durante a sua evolução foi submetida a atividades magmáticas (intrusivas e extrusivas), metamórficas relacionadas 
com forte tectonismo até finais do período Cretáceo e atividades sedimentáres (clásticas e quimicas) relacionadas com os periodos de calma que continuaram até o presente. No território cubano, selecionou-se a área Cuba CentroOriental, com uma extensão de $27000 \mathrm{Km}^{2}$, que representa $24 \%$ de toda a área do país. O resultado dos processos geológicos acontecidos, as intensidades e distribuição regular das precipitações, assim como os demais parâmetros climáticos e a configuração comprida e estreita na direção NO-SE, que condiciona uma drenagem das águas em duas vertentes opostas, asseguram na área de estudo selecionada, as bases para um modelo hidrogeoquímico interpretativo, aliás de uma representatividade extensiva ao resto do país e regiōes similares existentes na faixa do Trópico Úmido em outras partes do Mundo.

Para as características regionais da área de estudo e sobre a hipótese considerada, estabeleceu-se um modelo conceitual regional com a finalidade de poder utilizar os resultados sob considerações equivalentes. Este modelo considera para toda a região, os elementos de contorno a seguir: 1) As precipitações e demais fatores climáticos (temperatura e evaporação) constantes 2) A drenagem superficial e subterrânea, constante 3) Duas direções principais, ao norte e sul, das drenagens, superficial e subterrânea , desprezando as possibilidades das comunicações hidráulicas com os territórios lindeiros. 4) Carga hidráulica principal equivalente à altura do relevo sobre o nível médio do mar. Estas condicionantes permitem conceber o modelo como um sistema fechado e poder destacar as influencias particulares da participação da litologia no fluxo subterrâneo, interpretado através dos resultados do processamento hidrogeoquímico. Neste sentido foram selecionados os dados hidrogeológicos das formações representativas de distintas litologias nas distintas etapas geológicas, pois não se desconsiderou a possibilidade de destacar algum relacionamento entre a idade geológica e a idade relativa das águas.

Estas considerações aplicadas contribuíram com os resultados dos processamentos e interpretações. O enfoque inicial e a aplicação conseqüente dos aspetos avaliados, permitiram destacar e fundamentar a existência de um processo relacionado com o aumento constante da concentração do cloreto nas águas subterrâneas, chamado de Cloretogênese pelo autor, e de cujo processo foi deduzida uma expressão estatística nova para calcular a idade das águas subterrâneas. Por isso, considera-se que os objetivos principais foram conseguidos.

As particularidades do desenvolvimento da Tese, como a argumentação detalhada dos enfoques que fundamentaram a estruturação do processamento e análise da pesquisa, estão contidas nos capítulos específicos. 


\section{OBJETIVOS}

\section{Objetivos principais da pesquisa:}

-Pesquisa da experiência internacional sobre o uso da metodologia hidrogeoquímica na prospeção e nos estudos regionais hidrogeológicos.

-Aplicação e desenvolvimento de programas e técnicas de pesquisa hidrogeoquímicas para a obtenção de informação sobre as generalidades e particularidades da constituição e distribuição das águas subterrâneas com o fim de caracterizar o seu processo de formação.

-Investigação de associações entre a geologia da área de estudo e os modos de apresentação das águas com vistas de estabelecer analogias úteis às áreas de pouca ou nenhuma informação hidrogeológica.

-Planejamento do programa de coleta de amostras em Cuba com base em resultados do processamento já feito, que permita o rendimento máximo de cada ponto avaliado. 


\section{PESQUISA BIBLIOGRÁFICA}

A pesquisa bibliográfica foi feita tomando em conta os aspetos mais importantes do presente estudo:

\section{Recursos Hídricos Termais e Minerais.}

\section{2. Águas Termais e Minerais em Cuba.}

\section{Antecedentes documentais sobre as ocorrências das Águas Termais e Minerais na Área de Estudo.}

\section{Metodologia Hidrogeológica e Hidrogeoquímica}

\section{Recursos Hídricos Termais e Minerais}

A água mineral é um dos recursos naturais de nosso planeta. Diferencia-se das outras águas existentes pelas suas propriedades favoráveis à saúde humana, embora sejam utilizadas também para o bem-estar social como matéria prima energética ou fonte de determinados sais, devido a sua alta temperatura ou concentração específica, respectivamente.

O uso medicinal das águas minerais remonta-se à própria história da humanidade e fica registrado desde a época dos romanos e gregos na Europa e na civilização maya e tribos como os sioux, creeks e chippewas na América pré-colombiana (Armijo e San Martín , 1984).

No entanto, Mourão, 1998, estende, através dos descobrimentos arqueológicos na França, a história do uso das águas minerais muitos séculos antes da invasão romana ao país gálio, sublinhando também, pelos ossos encontrados ao redor destas fontes, o uso dos animais pré-históricos para os mesmos fines curativos.

Por isso, pode-se se atribuir aos romanos e gregos a cultura da exploração das águas minerais medicinais, mas não a origem do seu uso. Comparada com outros recursos da Terra como o Sol, o patrimônio do uso das águas minerais pertence a todos os seres viventes do planeta.

A fundamentação científica da aplicação medicinal das águas minerais na cultura ocidental centra-se em Hipócrates (460-377 a .C.) com o método Homeopático, indireto, no uso dos recursos naturais gerais (Bomtempo, 1994), ainda que Galeno (131-200) aplicava águas minerais específicas para determinadas curas com o seu método Alopático, direto (Mourão, 1998). Do ponto de vista geral não pode se desconsiderar a participação neste desenvolvimento da cultura oriental (China, Índia e Japão) através dos seus métodos curativos baseados na exploração das potencialidades do corpo humano. É agora neste século, graças à universalização das comunicações, quando estas culturas vão encontrando os seus pontos comuns. 
O fato de que estas águas emergidas da terra diferenciavam-se das restantes águas subterrâneas pela sua relação com alivios e curas de padecimentos humanos, mais eficientes quanto mais quentes, originou a associação nominal, de águas quentes com águas medicinais e, à vez, com águas minerais. Aquele uso curativo inicial, totalmente empírico, virou na atualidade, uso medicinal cientificamente avaliado sob as mesmas exigências de outras terapêuticas médicas. Estes estudos clínicos permitiram especificar que as propriedades curativas dependem principalmente das particularidades da sua composição físico-química e bacteriológica para grupos de doenças, com independência da sua temperatura (Armijo,1992). Tais especificações médicas fundamentam conceber o poder curativo como um atributo particular das águas minerais, mas não o único.

O uso da água mineral não esta restrito à medicina. Também é utilizada como calefação direta nas vivendas, fonte para produção de energia pela sua elevada temperatura, e como fonte de sais ( $\mathrm{NaCl}, \mathrm{K}, \mathrm{Br}$, etc.) pela sua alta concentração. É muito conhecido o seu uso atual como água de beber engarrafada não medicinal, mas com alguma contribuição para a saúde humana. As águas minerais engarrafadas, devido à poluição geral das águas que afetam os países, têm perdido o caracter de benefício específico para formarem-se em consumo seguro para a população. Por isso, na atualidade, o volume de consumo deste tipo de água engarrafada, é uma das medidas da qualidade de vida dos países.

Uma revisão das classificações das águas minerais permite afirmar que estão referidas principalmente, ao seu uso medicinal, porquanto a sua primeira condição é uma salinidade maior de $1000 \mathrm{mg} / \mathrm{L}$, exprimida através dos seus Sólidos Totais Dissolvidos (STD), e assim descritas nas respectivas legislações de Alemanha, Bélgica, Espanha, França, Grã Bretanha, Hungria, Japão, România, Suiça, USA e Antiga URSS (Sziksay, 1993). O recente desenvolvimento das águas minerais engarrafadas, ou águas minerais naturais, não considera limite enquanto ao conteúdo total de sais dissolvidas, de acordo com o documento Codex Alimantarius, da FAO (Organização das Nações Unidas para a Agricultura e a Alimentação). Os condicionantes mais restritivos estão relacionados com as exigências dos fatores que afetam as suas potabilidades.

A possibilidade do uso como bebida ou banho (tópico) das águas minerais medicinais the permite faixas de concentrações de alguns componentes, proibitivos aos requisitos diretos ao consumo humano das águas minerais naturais. Os chamados componentes bioativos que nas águas minerais medicinais consideram-se essenciais até em alta concentração $\left(\mathrm{H}_{2} \mathrm{~S}, \mathrm{Li}, \mathrm{Sr}\right.$, $\mathrm{Ba}, \mathrm{Br}$, As, etc.), nas águas minerais naturais são admitidos apenas na dose mínima da potabilidade.

O ponto comum entre as particularidades destas águas minerais medicinais e naturais é a ausência absoluta nas águas de microrganismos patogênicos. 
Outros aspetos comuns das águas minerais são aqueles relacionados com a consideração de recurso mineral para a legislação da sua exploração, ainda que os aspetos relacionados com os controles da sua qualidade durante a explotação não sejam totalmente assegurados (Valdés, 1998).

As águas minerais na atualidade, são diferenciadas segundo a aplicação específica em: 1.medicinais ou mineiro-medicinais, se são utilizadas no campo da Medicina; 2. Minerais naturais, se são engarrafadas para benefício da saúde, no campo de Alimentação; 3 . Industriais, se são utilizadas no campo da Indústria, para obter sais minerais ou aproveitar a sua energia térmica. Cada aplicação exige determinadas especificações para suas respectivas águas minerais. Cada uma delas tem exigências dos requisitos das suas qualidades físicas, físico-químicas e bacteriológicas para serem admitidas dentro do grupo considerado. As legislações de cada pais abordam esses requisitos de modo particular para aprovar as suas explorações. Nesta atividade, a classificação, assim como os requisitos de cada classificação, ainda são um tema controvertido entre os países que exploram as águas minerais. $\mathrm{Na}$ atualidade, o chamado Codex Alimentarius, da FAO (Organização das Nações Unidas para a Agricultura e a Alimentação) resulta em um documento internacionalmente admitido para as considerações das águas minerais naturais, ou de mesa, engarrafadas. Nestes aspetos, faz-se necessário especificar que dentro da denominação comercial geral de águas engarrafadas, estão as águas minerais naturais, cujos requisitos de qualidade da sua composição de sais específicos, higiene no ponto de engarrafamento, ausência de tratamentos para manter a sua qualidade para o consumo humano, as diferenciam daquelas que apenas Ihes exigem a qualidade da sua potabilidade e que são chamadas de águas de mesa ou de manancial. Concebe-se também a possibilidade de águas minerais medicinais engarrafas sob os requisitos particulares derivados da aplicação da água medicinal específica engarrafada. No caso da presente pesquisa, o autor acolhe-se à Norma Cubana das águas Minerais, NC 93-01-218, 1995 (Anexo I).

Em qualquer uma das suas aplicações, as águas minerais diferenciam-se entre elas mesmas pela sua composição físico-química e bacteriológica. Por isso, existem diferentes classificações, atendendo a determinada particularidade sob análise comparativa: $\mathrm{pH}$, temperatura, concentração ou mineralização total (determinadas como condutividade, sólidos totais dissolvidos ou resíduo seco), radioatividade, conteúdo e tipos de gases $\left(\mathrm{CO}_{2}, \mathrm{H}_{2} \mathrm{~S}, \mathrm{NH}_{4}, \mathrm{CH}_{4}, \mathrm{~N}_{2}\right)$, proporção da concentração na solução dos íons principais ou majoritários $\left(\mathrm{HCO}_{3}, \mathrm{SO}_{4}, \mathrm{Cl}\right.$, $\mathrm{Ca}, \mathrm{Mg}, \mathrm{Na}$ e $\mathrm{K}$ ), expressas geralmente em $\mathrm{mg} / \mathrm{L}$ ou $\mathrm{meq} / \mathrm{L}$, e na relativamente alta concentração na água de algum elemento metálico ou não. Neste último aspeto, faz-se necessário especificar que não é qualquer elemento minoritário existente que valoriza a água. São apenas os que a prática médica avalia como componentes bioativos: $\mathrm{Li}, \mathrm{Sr}, \mathrm{Ba}, \mathrm{Fe}, \mathrm{Br}, \mathrm{I}, \mathrm{As}, \mathrm{F}, \mathrm{H}_{3} \mathrm{BO}_{3}, \mathrm{H}_{2} \mathrm{SiO}_{3}$ e Rn. São assim nomeados porque são as sustâncias elementares que a Medicina reconhece hoje como de ação benéfica à saúde humana e aceitos sob determinada faixa de concentração. 
Os restantes não indicados estão ainda como não suficientemente avaliados para esse fim, ou como comprovadamente tóxicos à saúde, contaminantes, onde se distinguem o $\mathrm{Pb}, \mathrm{Hg}, \mathrm{Mn}, \mathrm{Cd}$ e metais radioativos pela sua freqüência no ambiente natural, geralmente estendidos através dos residuais vertidos pelos processos de mineração de minerais úteis.

Cada aspeto indicado no parágrafo anterior é quantitativamente agrupado nos seus valores mínimos, médios e máximos para estabelecer os limites das suas respectivas classificações. Infelizmente, não existe acordo geral nenhum e cada pais adota as classificações da sua conveniência nacional ou regional. Estas, às vezes, estão subordinadas até a critérios comerciais, muito evidenciados nas águas minerais engarrafadas, ou à relativa abundância ou escassez de determinados componentes nas águas minerais desses territórios.

Existem outras classificações muito específicas, principalmente na área da Medicina, segundo: 1) função terapêutica das águas medicinais, subdivididas pela forma da sua aplicação: tópica (banhos), pinicas (bebidas), atmiátricas (inalações) ou colutórios; 2) a concentração relacionada com o equivalente sanguíneo (hipo, iso e hipertônicas) e, 3) o benefício que pode reportar à saúde por médio das suas propriedades e composição físico-químicas : cloretadas, bicarbonatadas, sulfatadas, sulfurosas, ferruginosas, etc (Anexo II) Para qualquer uma das classificações que seja adotada, distingue-se a necessidade da existência de uma condição básica e comum a todas águas minerais: a constância das suas propriedades, cujo não cumprimento repercutiria no desaparecimento do seu valor de uso medicinal, bebida ou industrial. É, precisamente, esta exigência o requisito básico que a avaliação hidrogeológica deve garantir em qualquer um estudo para águas minerais. O campo unívoco da Hidrogeologia para ás águas minerais é a avaliação fundamentada da existência ou não do tipo de água mineral solicitada para o ritmo de explotação planejado. O campo das aplicações das águas minerais não pertence à Hidrogeologia.

\section{2. Águas Termais e Minerais em Cuba}

As águas minerais em Cuba tiveram um desenvolvimento similar ao resto do continente latino-americano, com as particularidades devido à sua condição insular. Os assentamentos cubanos conhecidos estão diretamente relacionados a presença de água. A cidade de La Habana, por exemplo, situada na etapa colonial na costa sul, mudou-se para a atual posição setentrional, perto do rio Almendares, uns dos rios maiores dessa província, por ser o único capaz de sustentar o crescimento populacional da época.

O pouco desenvolvimento econômico e social dos indígenas de Cuba no inicio da conquista pelos espanhóis não deixou rastros relacionados com águas minerais, diferente das civilizações indígenas da América continental, citados anteriormente. As histórias e lendas ao respeito remontam-se às descobertas pelos escravos fugidos, índios ou negros, que conseguiram sobreviver graças a estes tipos de águas, entre outros fatores. 
Descobrimentos similares foram gerando paulatinamente crescimentos de comunidades ao redor destas fontes, originando povoados quase sempre longe das cidades principais existentes, como San Diego de los Baños, na província de Pinar del Rio, Santa Maria del Rosario e Madruga, na província de La Habana, San Miguel de los Baños e Elguea, na província de Matanzas, Ciego Montero, na província de Cienfuegos e Camujiro, na província de Camaguey. Das províncias mais orientais (Santiago de Cuba, Bayamo, Holguin e Guantánamo) não se tem referencias indicadas de povoados originados destas causas, mas não podem ser descartadas tais possibilidades, devido as similitudes de condições sociais e geográficas com as restantes províncias ocidentais. Todo parece indicar alguma correspondência dos assentamentos ao redor dos mananciais minerais com o desenvolvimento socioeconômico da colônia, muito mais forte na parte ocidental cubana. As províncias com as maiores quantidades de fontes registradas da época são La Habana, Matanzas e Las Villas (Santa Clara, Cienfuegos e Sancti Spíritus na vigente divisão política). A geologia e clima são comuns para todo o território e não podem ser argumentadas considerações de índole natural para justificar a reduzida existência de águas minerais reportadas nas províncias mais orientais de Cuba.

O desenvolvimento econômico continuado desde a colônia Cuba até a República Cuba, trouxe o deterioração das fontes por contaminação e o seu correspondente abandono, sobretudo para aquelas mais relacionadas com o crescimento populacional ao seu redor. Comunidades surgidas na periferia da cidade de La Habana devido às fontes minerais, (hoje municípios) como Arroyo Naranjo, La Lisa e Guanabacoa, existem na atualidade, mas os mananciais que deram a sua origem, não (Valdés González ,1991).

A cultura balneária não alcançou o seu clímax na etapa republicana. Os esforços dos profissionais do Instituto Nacional de Hidrología y Climatología Médicas (primeiro desta natureza no país, e que existiu durante a etapa republicana até a chamada de etapa revolucionária), publicados através dos seus boletins periódicos, não lograram a procurada consideração dentro da estrutura econômica e científica do país.

Com exceção das águas minerais naturais engarrafadas, muitas das jazidas de águas minerais medicinais, foram poluídas, e portanto, abandonadas durante o desenvolvimento social da etapa pré-socialista.

O inicio da etapa revolucionaria com o estabelecimento do sistema social socialista a partir de 1959, acelera o desaparecimento das fontes de águas minerais, incluindo também às águas minerais engarrafadas, amplamente desenvolvidas desde finais do século XIX. Apenas sobreviveram algumas nas províncias ocidentais (San Diego de los Baños, Santa Maria del Rosario, Ciego Montero e Elguea). 
Deve-se considerar que os critérios da contaminação das águas subterrâneas por causa dos esgotos e demais vertimentos poluídos superficiais infiltrados no subsolo começaram se desenvolver amplamente a partir dos anos cinqüenta nos países desenvolvidos. Até então, o desconhecimento certo e confirmado dessas causas, contribuiu em alto grau para não consideração da contradição criada entre desenvolvimento social e a contaminação das fontes de águas subterrâneas. Por isso, quando descoberta a situação de deterioração da qualidade das águas das fontes, poucas vezes pode-se ter uma solução melhor que abandonar as suas explotações. Estas circunstâncias para as águas minerais estenderam-se em Cuba até a década de oitenta.

Em meado da década do 80 marca-se o ressurgimento da atenção às fontes de águas minerais e a reconsideração da sua cultura de uso. Os profissionais do ramo lançam-se aos estudos hidrogeológicos destas fontes (existentes e novas), aos estudos clínicos da sua utilização e aos estudos econômicos da sua explotação. Começa o Termalismo cubano.

Com o desenvolvimento dos estudos das jazidas de águas minerais começa o reconhecimento profissional dos problemas hidrogeológicos particulares destes recursos. As bases técnicas são muito reduzidas, dentro das quais pode-se citar acertadas obras hidrogeológicas generalizadoras, como as de Jorge Brodermann, J. (1948), Ratislav Melioris (1968) e Rafael Lavandero et al (1987).

Entre as mesmas pode-se dizer que, do ponto de vista cartográfico, Lavandero et al (1987), é a mais completa e pode se considerar como uns dos melhores esforços geológicos naquele ambiente nacional de desconhecimento dos requerimentos e possibilidades deste recurso hidromineral. No caso de Brodermann, J. (1948) resulta uma obra pioneira na Hidrogeologia cubana, pois na época, esta especialidade ainda não estava desenvolvida no país. Melioris, R. (1968) fez uma generalização das águas minerais cubanas que, devido à falta de cultura cubana sobre esta parte especializada da Hidrogeologia e ao desinteresse nacional pela exploração destes recursos, infelizmente resultou um simples antecedente, sem nenhuma outra contribuição. $O$ desenvolvimento dos estudos hidrogeológicos das águas minerais teve como as suas bases à experiência européia.

As bases técnicas e de legislações européias para este fim não resultaram individualmente na melhor aplicação. As diferentes considerações utilizadas nos diferentes países, fizeram evidenciar a inutilidade de adotar as de um pais em particular, mas também evidenciaram a conveniência de adequar e adotar as experiências daqueles mais desenvolvidos neste ramo. Selecionaram-se critérios de Espanha, França, Alemanha e Rússia para a consideração e aplicação dos diferentes requisitos por eles utilizados, nas jazidas cubanas de águas minerais. 
Devido as águas minerais terem uma componente comercial, mesmo medicinal ou engarrafada, apenas subordinada ao seu caracter de mineral, permite dizer que é a classificação da água mineral existente quem decide o valor comercial ou não. Por isso, os países ou regiões de países, tem adequado as classificações das águas minerais às suas próprias conveniências de acordo às suas próprias características territoriais. Importar uma classificação, sem a devida consideração das características técnicas, sociais e comerciais particulares e gerais existentes destes recursos, pode causar mais danos que benefícios ao país importador. Esta situação foi corrigida com a aprovação nacional em 1995 da Norma Cubana de Águas Minerais (NC 93-01-218:95), em diferentes reuniões com especialistas dos principais ramos relacionados com o tema (Ministérios da Saúde, Alimentação, Turismo e Industria Básica) a partir de uma proposta feita pelo autor. Para a fundamentação da referida proposta, o autor consultou as normas cubanas, estrangeiras, internacionais e outros documentos (incluindo leis e decretos) da França, Espanha, EUA, Japão e Itália.

A diferença entre os valores de requisitos para as águas minerais tomadas da antiga URSS no mapa de Lavandero et al (1987) e os requisitos vigentes na Norma Cubana pode ser apreciada na Tabela No. 1. Foram associados com a norma cubana nesta tabela apenas os componentes apresentados no mapa de 1987.

\section{TABELA 1. COMPARAÇÃO ENTRE OS REQUERIMENTOS PARA AS ÁGUAS MINERAIS EM 1987 E EM 1995}

\begin{tabular}{|c|c|c|}
\hline \multirow{2}{*}{$\begin{array}{c}\text { COMPONENTES } \\
\text { CONSIDERADOS } \\
\text { (mg/L) }\end{array}$} & \multicolumn{2}{|c|}{ DOCUMENTOS COMPARADOS } \\
\cline { 2 - 3 } & $\begin{array}{c}\text { Mapa de Lavandero et al } \\
(\mathbf{1 9 8 7})\end{array}$ & $\begin{array}{c}\text { Normas em vigor } \\
(\mathbf{1 9 9 5 )}\end{array}$ \\
\hline $\mathrm{H}_{2} \mathrm{SiO}_{3}$ & $>50,0$ & $>50,0$ \\
\hline $\mathrm{F}$ & $5,0----8,0$ & $1,0-\cdots-2,0$ \\
\hline $\mathrm{Br}$ & $>25,0$ & $>4,0$ \\
\hline $\mathrm{Fe}$ & $>20,0$ & $>5,0$ \\
\hline $\mathrm{As}$ & $>0,7$ & $0,2---1,0$ \\
\hline $\mathrm{H}{ }_{2} \mathrm{~S}$ & $>20,0$ & $>1,0$ \\
\hline $\begin{array}{c}\text { Mineralização (STD) } \\
(\mathrm{g} / \mathrm{L})\end{array}$ & $>2,0$ & $<0,2 \quad \mathrm{e} \quad>1,0$ \\
\hline
\end{tabular}

Evidentemente, um novo mapa na atualidade, apresentaria uma outra quantidade e distribuição de possíveis fontes hidrominerais. 
Uma norma como a que foi estabelecida criou uma linguagem comum entre todos os profissionais relacionados com a exploração das águas minerais. No caso particular da pesquisa hidrogeológica, as avaliações tiveram resultados locais, segundo as diferentes jazidas, mas não solucionavam as regularidades de apresentação e gêneses no território.

As condições insulares com uma geologia complexa num trópico úmido não davam muitas possibilidades de analogia com os países de mais experiências nas pesquisas hidrogeológicas de águas minerais, como são os países europeus, devido às suas condições originais continentais e clima temperado. O Japão apresenta condições insulares e geologia tão complexa como Cuba, e com uma cultura termalista ancestral que pudesse bem ser utilizado como exemplo de referência, mas sua analogia seria muito limitada, devido sua ampla distribuição de vulcanismo e sismicidade, pouco comum com Cuba.

Em 1995, Cuba tinha avaliado 40 fontes de água mineral, 21 medicinal e 19 natural, com diferentes níveis de estudo hidrogeológico, prontas para sua explotação. A avaliação de todas as fontes de águas minerais medicinais permite concluir, enquanto às temperaturas das suas águas, que não ultrapassam os $51^{\circ} \mathrm{C}$, registrados na jazida de Elguea, na província de Villa Clara. No existem registradas águas medicinais com temperaturas superiores. As temperaturas mais freqüentes encontradas em fontes de águas minerais, flutuam em volta dos $30-32^{\circ} \mathrm{C}$. A ausência de vulcanismo ativo em Cuba, fundamenta a impossibilidade de esperar altas temperaturas. As principais causas das temperaturas superiores ao meio ambiente estão no gradiente geotérmico e as derivadas da desintegração de componentes radioativos e dos processos exotérmicos da decomposição da pirita.

A Tabela 2 apresenta um resumo das temperaturas registradas nas fontes de Cuba. Nela as águas minerais naturais, para bebida engarrafada, não ultrapassam os valores de temperatura entre os 20 e $30^{\circ} \mathrm{C}$, que são também os valores médios da temperatura do ar em Cuba. É visivel que estas águas estão diretamente relacionadas com as condições superficiais do território do lugar das respectivas jazidas. No caso das águas minerais medicinais faz-se evidente temperaturas superiores ao meio ambiental e cuja constância dos seus valores, além das suas particulares composições químicas, permitem-lhe o uso terapêutico nos seus respectivos balneários.

O nome repetido de La Cotorra em duas províncias diferentes não é erro, senão que foram duas fontes que se comercializaram independentemente com esses nomes e hoje, tal vez devido a problemas históricos regionais, não há concordância entre as empresas de mudar para outro nome.

O fato evidente na Tabela 2 de ter quase todas as provincias uma ou duas fontes de águas engarrafadas responde ao cumprimento da programação inicial do desenvolvimento da exploração das águas minerais no país, para o qual se investiu nas respectivas pesquisas com o fim de que cada província tivesse sua respectiva indústria de venda de água para beber e assim evitar o transporte a longa distância entre províncias. 
TABELA 2. RELAÇÃO DAS TEMPERATURAS DAS ÁGUAS MINERAIS DE CUBA.

\begin{tabular}{|c|c|c|c|c|}
\hline Província & $\begin{array}{c}\text { Água Mineral } \\
\text { Natural } \\
\text { (engarrafada) }\end{array}$ & $\begin{array}{c}\text { Temp } \\
\left(20-30^{\circ} \mathrm{C}\right) \\
\text { (Frias) }\end{array}$ & $\begin{array}{l}\text { Água Mineral } \\
\text { Medicinal }\end{array}$ & Temp. $\left({ }^{0} \mathrm{C}\right)$ \\
\hline \multirow{4}{*}{ Pinar Del Rio } & Aguas Claras & - & San Diego & $30-40$ \\
\hline & & & Bermejales & $30-40$ \\
\hline & & & San Vicente & 32 \\
\hline & & & Soroa & 28 \\
\hline \multirow{3}{*}{$\begin{array}{l}\text { Isla de la } \\
\text { Juventud }\end{array}$} & La Cotorra & 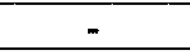 & La Fe & 32 \\
\hline & & & Delita & 28-32 \\
\hline & & & La Magnesia & 32 \\
\hline \multirow[t]{2}{*}{$\begin{array}{c}\text { Ciudad de La } \\
\text { Habana }\end{array}$} & La Cotorra & - & $\begin{array}{c}\text { Santa Maria del } \\
\text { Rosario }\end{array}$ & 28 \\
\hline & San Agustin & $=$ & EI Sulfuroso & 28 \\
\hline Habana & El Copey & - & La Paila & 28 \\
\hline \multirow[t]{2}{*}{ Matanzas } & Mayabe & - & $\begin{array}{c}\text { San Miguel de } \\
\text { Ios Baños }\end{array}$ & 28 \\
\hline & & & Menendez & 40 \\
\hline Villa Clara & Amaro & - & Elguea & 51 \\
\hline Sancti Spíritu & $\begin{array}{c}\text { San José de los } \\
\text { Lagos } \\
\end{array}$ & - & $\begin{array}{c}\begin{array}{c}\text { San José de los } \\
\text { Lagos }\end{array} \\
\end{array}$ & 33 \\
\hline \multirow[t]{2}{*}{ Cienfuegos } & Ciego Montero & - & Ciego Montero & 43 \\
\hline & $\begin{array}{l}\text { Topes de } \\
\text { Collantes }\end{array}$ & - & & \\
\hline \multirow[t]{2}{*}{ Ciego de Avila } & La Palma & - & Veracruz & 26 \\
\hline & & & El Azufre & 29 \\
\hline \multirow[t]{3}{*}{ Camaguey } & Tínima & - & Camujiro & 35 \\
\hline & Paso de Lesca & - & & \\
\hline & Peña Azul & - & & \\
\hline Las Tunas & Chaparra & - & & \\
\hline \multirow[t]{2}{*}{ Holguin } & El Fraile & - & & \\
\hline & Guardalavaca & - & & \\
\hline Granma & Monte Alto & - & $\begin{array}{c}\text { Marea del } \\
\text { Portillo } \\
\end{array}$ & 34 \\
\hline \multirow{2}{*}{$\begin{array}{l}\text { Santiago de } \\
\text { Cuba }\end{array}$} & El Caney & - & EI Cedrón & 41 \\
\hline & & & La Cuquita & 36 \\
\hline Guantánamo & - & & - & \\
\hline
\end{tabular}

Fonte : Valdés, 1990. Controles de trabalho, registro pessoal. 


\section{Antecedentes documentais sobre as ocorrências das Águas Termais e Minerais na Área de Estudo.}

Entre os trabalhos generalizadores das ocorrências das águas minerais no território sob estudo estão os de Melioris, R (1968), Águas Minerais de Cuba, e Lavandero et al (1987), Mapa das Jazidas de Minerais Metálicos e Águas Minerais de Cuba, escala 1:250000. Outras publicações cubanas abrangem apenas limitadas manifestações, embora mais detalhadas (Archivos del Instituto de Hidrologia y Climatologia Médicas, del Ministerio de Salubridad y Asistencia Social e explorações hidrogeológicas das jazidas Veracruz, El Azufre, Tamarindo, Tínima, Peña Azul, Paso de Lesca, Chaparra e Camujiro da Unión Geólogo-Minera del Ministerio de la Industria Básica ). O último trabalho realizado por esta empresa é a Regionalização das Águas Minerais das províncias Ciego de Ávila, Camaguey e Lãs Tunas (Rodriguez et al, 1996).

A obra de Lavandero et al (1987), que abrange o país completo, apresenta apenas os pontos hidrominerais atendendo a suas composições aniônicas com indicações isoladas sobre alguns valores catiônicos.

O estudo de Rodriguez et al (1996) a pesar de desenvolver-se dentro das províncias específicas da região centro-oriental e de operar com muitos mais pontos que Lavandero et al, apenas consegue demarcar 13 zonas nas quais predomina um tipo hidroquímico de água mineral de interesse, mas não generaliza as suas distribuições e apresentações com o resto do território.

Este trabalho de Rodriguez et al, do qual o autor utilizou os seus dados primários para desenvolver a presente tese, não ultrapassam os esquemas clássicos da agrupação hidrogeológica. O uso de índices de descriminação absoluta, como o Índice Geoquímico (IGQ) para determinar a origem das águas (recém infiltradas, de zonas de recarga e profundas) faz concluir como águas de infiltração recente algumas com STD> $2 \mathrm{~g} / \mathrm{L}$. Exemplos como o anterior, associados a uma fraca apreciação dos possíveis movimentos das águas subterrâneas dentro do contexto geológico, dá lugar a concluir como água proveniente da zona de recarga, águas cloretadas sódicas com STD = 4,22 g/L (zona No. 6). Por outro lado, o uso da Fórmula de Kurlov para zonificar o quimismo das águas subterrâneas na escala regional, resulta ilustrativo e até conclusivo em regiões de geologia uniforme, mas não ajuda muito para avaliar a gênese das águas numa geologia insular complexa, como é particularmente a região de estudo.

Com independência dos esquemas hidrogeológicos assumidos, o autor abordará no item III.4, sobre os problemas existentes nas metodologias hidrogeológicas regionais, com ênfase na metodologia hidrogeoquímica, que permitirão compreender que as atuais limitações da metodologia hidrogeoquímica regional, não permitem ainda conseguir uma avaliação mais completa e abrangente para o contexto geral das relações águas/rochas em escala regional. 
Ainda que a apresentação de mananciais hidromineral esteja associada á existência de falhas, zonas de gretamentos e contatos derivados das atividades tectônicas, o valor principal da composição deste recurso é atributo do modo e permanência da sua circulação através dos diferentes meios rochosos. A experiência internacional (Schoeller, 1955; Davis e Dewiest, 1966; Vuillemenot e Toulhoat, 1992; Speiran e Aucott, 1994 ) fundamenta cada tipo hidrogeoquímico sem o concurso do tectonismo como seu ente formador. Isso não despreza sua devida participação dentro dos processos modificadores

Uma interpretação preliminar ao começo do processamento da informação coletada até 1994 de Cuba Centro-Oriental permitiu obter algumas considerações úteis como guia aos enfoques do processamento da documentação de 1996 para a avaliação e confecção da presente pesquisa. Com este fim, sob a base da discussão precedente, foram agrupados os dois aspetos a seguir :

\section{a. Sobre o quimismo das águas minerais}

1-É necessário discernir primeiro as generalidades do quimismo das águas subterrâneas para poder abordar o quimismo das águas minerais como uma parte desse processo geral.

2-A análise do processo que origina o quimismo das águas subterrâneas será desenvolvida a partir do processamento e interpretação do comportamento dos seus ânions diluídos.

3-A origem das águas cloretadas pode estar relacionada com águas marinhas antigas (conatas), com alguma outra origem causada pela circulação em profundidade ou com águas associada ás existências de petróleo, o que obriga precisar sua gênese por meio de exaustivo processamento deste tipo aniônico.

4-A origem das águas bicarbonatadas parece associada á circulação superficial, mas a influência ainda desconhecida da profundidade da ação do $\mathrm{CO}_{2}$ neste clima tropical úmido deixa dúvidas sobre as profundidades de circulação destas águas, questão a solucionar com o concurso das técnicas isotópicas ou das técnicas de processamento hidrogeoquímico, em especial com respeito ás variações das profundidades.

5-O quimismo misturado destes tipos aniónicos parecem representar, os estados intermediários entre cada um deles, de modo similar a interface água doce/água de mar, pelo que a sua propagação e valores da mistura serão úteis para procurar a posição vertical ou horizontal dos tipos aniônicos originais. Este fato poderá contribuir, além disso, para outras considerações sobre a estabilidade das composições químicas das águas subterrâneas e minerais.

\section{b. Sobre a geologia associada ás águas subterrâneas e minerais.}

1-Existe uma continuidade comum da associação água/rocha entre as regiões estudadas, o que permite o uso de métodos análogos para formações geológicas similares. 
2-Os aqüiferos das rochas com maiores possibilidades hidrominerais são aqueles de gênese pré-neogênica.

3-A distribuição de quantidades similares dos tipos cloretados e bicarbonatados nas diferentes formações geológicas não permite estabelecer uma melhor diferenciação entre elas e as rochas, o que alerta sobre a necessidade de precisar bem este aspecto.

4-Os tipos misturados têm mais freqüência nas proximidades das mudanças litológicas que dentro dos mesmos tipos litológicos. Isso, e o tectonismo existente, indicam a necessidade da segurança da locação dos pontos cartografados para a devida certeza da interpretação e avaliação destes tipos hidrominerais.

5-No caso dos maciços ofiolíticos presentes na região, deve-se ter especial atenção quanto ao quimismo das águas no seu interior e na sua periferia, pelo valor decisivo que pode representar para a interpretação dos mecanismos da recarga e formação das águas subterrâneas e minerais no território cubano.

Nesta análise preliminar utilizou-se como fundamentação e guia às considerações mais importantes para o cumprimento dos objetivos da Tese. Daí, que o procedimento para conseguir os objetivos, dividiu-se em:

- Estabelecer com a utilização das técnicas de processamento hidrogeoquímico as relações da associação hidroquímico/tipo rocha e a sua distribuição na área de estudo.

-Estabelecer as distintas dependências da evolução e apresentação dos tipos hidrogeoquímicos no contexto geológico da região.

-Avaliar as condições hidrogeológicas existentes a partir dos resultados da análise hidrogeoquímica.

-Estabelecer os condicionantes hidrogeológicos para o prognóstico e prospeção das jazidas de águas minerais no território.

-Recomendar enfoques e demais considerações para pesquisas posteriores no território, outras regiões de Cuba ou de outros países de condições similares..

\section{Metodologia Hidrogeológica e Hidrogeoquímica}

Método hidrogeoquímico, como a metodologia principal a desenvolver dentro as metodologias hidrogeológicas, foi o selecionado devido a que o atributo essencial das águas minerais é a sua composição, obtida através do meio geológico de circulação. Da sua entrada no subsolo até a sua saída na superfície, a composição química da água subterrânea é a resultante dos processos físico-químicos e bacteriológicos que desenvolvem-se, tais como: regime climático, composição e distribuição petrográfica e regularidades e heterogeneidade dos caminhos de circulação. Por isso a análise para a 
avaliação hidrogeológica das águas minerais precisa da gênese e variações hidrogeoquímicas das águas minerais e das demais águas subterrâneas não mineralizadas.

O Método Hidrogeoquímico, no qual o autor pensou explorar ao máximo a sua aplicação nas águas minerais, encontrou nele partes inacabadas ou não totalmente concluídas para a sua utilização completa nos objetivos da Tese.

\subsection{Generalidades sobre a aplicação do Método Hidrogeoquímico}

A especialidade de maior afinidade com a Hidrogeoquímica, e provavelmente a que contribuiu a fundamentar esse termo, a Geoquímica, parece preferir os termos: reconhecimento da drenagem geoquímica ("geochemical drainage reconnaissance")(Webb, 1994), mapeamento geoquímico de correntes de sedimentos ("stream sediments geochemical mapping") (Simpson, 1991), ou mais recentemente, geoquímica ambiental ("environmental geochemistry") (Duvenport,1993; Darnley, Bjorklund et al, 1995; Andrews, Brimblecombe et al, 1996) para qualificar a intervenção dos procedimentos da analise dos comportamentos da composição química das águas naturais para os fins da prospeção para a mineração e a contaminação ambiental. Não podemos desconsiderar aqueles que nas suas pesquisas ainda empregam justamente 0 termo hidrogeoquímica (Benneth e Wagner, 1983; Lovell, Meyer e Atkinson, 1983; Rose, Wesolovski e Smith, 1983; Fisher e Mullican, 1997) sem tentar modificá-lo.

Neste sentido, é interessante observar que no livro de Rosler e Lange, Geochemical Tables, 1972, aparece entre aspas Biogeoquímica ("Biogeochemistry") para representar num só termo a Geoquímica da matéria vivente ("geochemistry of living matter"), enquanto que nos incisos anteriores cita, sem termo algum específico: geoquímica das águas de mares profundos, distribuição dos elementos nas águas doces e geoquímica das águas minerais (geochemistry of deep sea waters, distribuition of elements in fresh waters $e$ geochemistry of mineral waters), respectivamente. Evidentemente, não se reconheceu o termo Hidrogeoquímica (Hydrogeochemistry) que podesse conciliá-los.

Todos os hidrogeólogos reconhecidos internacionalmente através das suas obras concordam na importância dos métodos hidrogeoquímicos nos estudos desse campo especializado. Desde Schoeller, 1962, para começar com uns dos pioneiros deles, até Plotnikov, 1962; Mandel e Shiftan, 1981; Matthess, 1982; Milnes, 1985; Erdélyc e Galfi 1988; Szikszay, 1993 e Mestrinho, 1994, para agrupar autores com diferentes tendências no mesmo alvo.

Mas, aprofundando nestas obras especializadas citadas, com a vontade de encontrar uma definição metodológica da Hidrogeoquímica aplicada à pesquisa hidrogeológica, com níveis similares à aplicação dos métodos Hidrodinámicos ou Geofísicos, encontram-se outras considerações, como por exemplo :

Schoeller (1962), indiscutivel promotor dos métodos hidrogeoquímicos, no seu capítulo VII, enfoca a prospeção hidrogeológica através dos mapas geológicos, 
hidrogeológicos especializados, sem especificar o mapa hidrogeoquímico, apesar de ser ele, uns dos que fundamentou o uso e interpretação destes tipos de mapas. Quando ele refere-se à avaliação da exploração das capas aqüíferas, apenas emprega o formulário hidrodinámico já conhecido para estas situações.

Plotnikov (1962), no seu capitulo IX sobre as observações hidrogeológicas, em "Resources in eaux souterraines: clasification et methods d'evaluation", não menciona o quimismo das águas nem dos aspetos que devem valorarizar a precisão das suas medidas e erros. No seu capítulo XI, Qualidade das águas subterrâneas, menciona sua importância para avaliar a sua origem, mas não para a avaliação inicial de estudo. Em geral, é mencionada a necessidade de avaliar a qualidade das águas, mas não com o peso de um método a ser aplicado.

Mandel e Shifton (1981), no seu capítulo IX, Geochemical methods (observar: não Hydrogeochemical methods) em Groundwater Resources, expõe uma ordem lógica para a interpretação dos dados químicos, mas no capítulo XIII, na exploração regional, o único problema para o "sustained yield" (rendimento sustentável) parece ser a intrusão marinha, único problema hidrogeoquímico. Mesmo assim, no cap. XIV, o problema nas redes de observação é apenas monitorar a qualidade das águas. Avaliar o comportamento do sistema hidrogeológico através da distribuição das diferentes composições hidroquímicas não é objetivo das redes de observação.

Os outros autores apresentam observações similares, a excepção de Erdélyc e Galfi (1988), que no seu Surface and Subsurface Mapping in Hydrogeology, detalha os aspetos hidrogeoquímicos com o mesmo peso que os restantes métodos hidrogeológicos.

É reconhecida a importância dos modelos na economia das explorações (Jensen Hogh, 1987), embora o desenvolvimento teórico seja mais forte nos fatores físicos (Silva, 1995) que no campo das variáveis hidrogeoquímicas, onde ainda os processamentos e resultados melhores ficam para os casos da intrusão marinha e das duas fases da contaminação (Morales-Jubeira et al, 1987 ;Wanfung, Wheater e Johnson, 1997).

Os trabalhos práticos mais recentes nesta especialidade (Afsin, 1997; Atwia et al,1997; Awad et al, 1997; Dazy et al, 1997; Deering et al , 1983; Dunm, 1990; Kumer et al, 1997; Lalonde, 1983; Lovell et al, 1983; Scheytt, 1997; Srivinoso et al, 1997) não ultrapassam estes limites indicados ao método hidrogeoquímico .

\subsection{Cartografía Hidrogeoquímica}

A consulta na bibliografia especializada indica que a cartografia hidrogeológica ainda não é um aspecto definitivamente acabado dentre os componentes desta atividade, segundo os critérios comuns como sustentam os especialistas (Struckmeier e Margat, 1989; Collins, 1991 ). Apesar do emprego de técnicas 
de ponta, como o sensoriamento remoto (Berard, 1990 ; Kruck, 1992), mantémse como critério comum a participação imprescindivel do hidrogeólogo na interpretação e conformação dos dados levantados, sejam diretos do campo ou por registro documental (Castany, 1968; Custodio, 1976; Sabine, 1985; Erdélyc, 1988; Struckmeier e Krampe, 1992).

Os citados autores concordam na totalidade que o mapa hidrogeológico é o objetivo máximo a cumprir, como documento representativo dos fatores que operam no desenvolvimento e avaliação das águas subterrâneas e suas interdependências com o meio circulante, segundo a sua futura utilização na economia nacional ou local.

Uma revisão dos autores sobre a temática cartografia hidrogeológica (Castany, 1968; Custodio, 1976 e Erdélyc, 1988) permite afirmar que as águas minerais não estão tacitamente compreendidas nesta temática. Pode-se observar tal afirmação na Legenda Internacional dos Mapas Hidrogeológicos da UNESCO, contida na já referida obra de Emilio Custodio. Nela evidencia-se a ausência de simbologia para algumas especificações cartográficas necessárias para as águas minerais como, por exemplo, associações tipo hidroquímico/ tipo litológico, zoneamentos verticais ou horizontais, gêneses, etc.

A expressão generalizadora e útil da distribuição do conjunto das águas minerais, exigida nos mapas hidrogeológicos regionais de pequena escala, ainda não supera, no mundo ocidental, a apresentação apenas de uma relação de pontos hidrogeoquímicos sobre a geologia territorial, ou a zoneamento de regiões dos diferentes tipos hidrominerais pela sua exposição na superfície (Pomerol e Ricour, 1992; Pinagua Espejel, 1992)

No entanto, existem mapas especializados de alcance regional em determinados aspectos da temática das águas minerais como, por exemplo, da sua temperatura (Hamza e Eston, 1981; Edwards,1982). Também, mas no âmbito local, os mapas emanados de estudos de um fator mineralizante (Powell, 1985; Kimmelmann et al, 1990), um fator hidráulico (Chevalier-Lenire, 1989), e , ultimamente aqueles confeccionados pelo método de investigação isotópico (Dray, 1989; Aranyossy, 1989; Kimmmelman et al, 1989; Fontes, 1989; Bison, 1989; Fouillec, 1989; Sorrot, 1989). O Mapa Hidrogeológico de América do Sul, escala 1:5000000, (PHI, UNESCO, 1996) quase não faz utilização do aspeto químico das águas nos países compreendidos, muito menos menção às águas minerais.

Como uma conclusão sobre este tópico, consideramos que, no caso das águas minerais, a cartografia específica para os propósitos investigativos regionais e para sua devida interpretação conveniente aos fins da economia do país, não estar totalmente conjugada.

\subsection{Particularidades da cartografia executada}

Apesar das singularidades demostradas para a cartografia hidrogeoquímica, não devemos desconsiderar a existência generalizada de padrões internacionais que regulam quantidade de pontos utilizados por unidade de 
área ou densidade $\left(\mathrm{N}^{\circ}\right.$. de pontos $\left./ \mathrm{Km}^{2}\right)$, escala a utilizar para o mapa em execução e finalidades que devem ou admitissem ser conseguidas, segundo o cumprimento da relação densidade/escala.

Estes padrões para a Hidrogeologia estão relacionados com os trabalhos e volumes de trabalho e regulam a quantidade de trabalho especializado e objetivos mínimos para cada escala (Rebouças,1996). Como o volume principal de dados é de caracter hidroquímico, analisou-se esta situação referenciando-a a quantidade de Análises Química padrão na "Orientação para Programação e Avaliação de Estudos Hidrogeológicos" (Rebouças, 1996). Tal requerimento é o mesmo que para Inventários de Pontos de Águas no documento citado, permitindo abordar a mesma análise por ambos aspetos.

Para a extensão da área estudada, $27000 \mathrm{Km}^{2}$, as densidades requeridas foram: (No. de pontos requeridos $=$ densidade requerida $\mathrm{x}$ área utilizada) de : 270 pontos para 1:500 000 e 1080 pontos para 1:250 000, de acordo com o sugerido por Rebouças (1996).

No caso das exigências para o aspeto de Análises Químicas, esse volume apenas infere "determinações de condutividade elétrica e cálculo total de sais", a excepção de "20-30\% das amostras " que devem ser enviadas para laboratório". Este por cento exigido trata de compensar os custos mínimos de laboratório para o resultado requerido. Evidentemente, $100 \%$ seria ótimo para os resultados, mas não para a economia dos investimentos aplicados. Sobre este ponto de vista, $30 \%$ exigido seria de 81 pontos para a escala 1:500 000 e 324 para a escala 1:250000.

O volume final exato obtido, que foi o utilizado para as interpretações da Tese, foi de 736 pontos. Este volume total refere-se ao valor correspondente aos pontos com o conjunto completo das determinações das concentrações dos sais principais. Pelo objetivo do processamento efetuado, não se considerou os pontos com menor informação. A quantidade 736 representa o requerido $30 \%$ da documentação máxima das amostras, mas neste trabalho significa ter utilizado o $100 \%$ dos pontos com determinações de laboratório, o que permite admitir a otimização da documentação processada.

Assim concluímos que o Nível de Estudo alcançado, sob o padrão tabelado nos Estudos Hidrogeológicos, pode ser considerado como de Estudo de Reconhecimento, por representar os resultados na faixa de escalas entre $1: 250000$ e 1:500000. Mas, para chegar à justa consideração do possível nivel que a presente pesquisa pudesse alcançar, deve-se mencionar que o objetivo relaciona-se principalmente com resultados hidrogeoquímicos. Por isso, do ponto de vista iminentemente hidrogeoquímico, comparou-se o volume de dados utilizados com similares publicados, de teses do Instituto de Geociências principalmente, confeccionando-se a Tabela No. 3. 


\section{TABELA 3 . RELAÇÃO DA DENSIDADE DE TRABALHO CONSEGUIDAS EM PESQUISAS HIDROGEOQUÍMICAS (1-10, Trabalhos da USP)}

\begin{tabular}{|c|c|c|c|c|}
\hline No. & Ptos. Totais & Area $\left(\mathrm{Km}^{2}\right)$ & $\begin{array}{l}\text { Densidade } \\
\left(\text { Pto } / \mathrm{Km}^{2}\right)\end{array}$ & Autores/Ano \\
\hline 1 & 7 & 0.8 & 8.75 & Blat, Kimmelmann, Pacheco(1994) \\
\hline 2 & 1364 & 2200 & 0.62 & Cavalheiro, H. e Navajas Sampaio, C. (1994) \\
\hline 3 & 33 & Não indicada & & Celligoi, A . e Duarte, U. (1994) \\
\hline 4 & 44 & 40 & 1.1 & Barbagallo, Vizcaino,González Campos (1994) \\
\hline 5 & 336 & 104000 & 0.0032 & Campos, H.C. (1995) \\
\hline 6 & 1364 & 247898 & 0.0055 & Campos, H.C. (a) (1995) \\
\hline 7 & 108 & 25000 & 0.0043 & Diniz, J.A. (1996) \\
\hline 8 & No indicado & 4000 & & Moura, F. A. (1996) \\
\hline 9 & 510 & 4870 & 0.104 & Santos, A.C. (1996) \\
\hline 10 & 113 & 15000 & 0.0075 & Hendry, M.J. e Schwartz, F.W. (1988) \\
\hline 11 & 36 & 14 & 2.57 & Nativ, Halleran, Hunley (1997) \\
\hline 12 & 736 & 27000 & 0.027 & Autor (2001) \\
\hline
\end{tabular}

Os valores das áreas permitem estimar o caracter local ou regional das pesquisas relacionadas. Comparando os valores das densidades alcançadas nas pesquisas selecionadas em áreas maiores de $15000 \mathrm{~km}^{2}$, pode-se notar que o autor conseguiu aumentar a densidade para estes trabalhos de grandes áreas, regionais.

\subsection{As técnicas de processamentos}

O volume de dados com que contou este trabalho foi da ordem de 5000 pontos, obtidos de um trabalho de recopilação da informação hidrogeológica preexistente na região sob estudo (as províncias de Ciego de Avila, Camaguey e Las Tunas), feito pela Empresa Geologo-Minera de Camaguey (Rodriguez et al, 1996).

Estes dados do trabalho citado foram documentados em distintos trabalhos existentes, semi-regionais e locais principalmente, executados pelas diferentes entidades produtivas das províncias, empresas provinciais do Instituto de Recursos Hidráulicos e do Ministério da Industria Básica, entre as principais. A diversidade de objetivos dos trabalhos documentados, os diferentes tipos de documentação e qualidade dos registros efetuados dos pontos coletados, fizeram com que a documentação final registrada fosse incompleta quanto a informação total por pontos.

Para este estudo foram resgatados o máximo dos volumes registrados e informações existentes que pudessem servir de experiências na correção e aproveitamentos de dados em outros trabalhos regionais similares. Por outro lado, a revalidação de dados anteriores e a segurança para o seu uso atual, permite a redução dos custos investidos nas prospeções hidrogeológicas, ao reduzir o volume de novas amostragens nas áreas sob estudo. Não são poucos os trabalhos que desconsideram a informação antecedente, sobre tudo as informações hidroquímicas, por suspeitá-la de baixa qualidade. 
O campo do processamento hidrogeoquímico é tão amplo como complexo. As múltiplas interações água-rocha dos processos que acontecem no meio subterrâneo para formar os diferentes tipos de águas estão ainda longe de ser entendidas na sua totalidade. Por isso, o exame das ferramentas existentes, faz concluir que elas apenas permitem descobrir possibilidades para soluções parciais às condicionantes apresentadas no meio natural. Tais circunstâncias fundamentam a necessidade procurar linhas de pesquisas de processamentos hidrogeoquímicos para grandes extensões, que facilitem o melhor desenvolvimento desta metodologia de investigação hidrogeológica.

Sobre a base das considerações iniciais explicadas na item 4.21 foram analisadas algumas dependências entre a condutividade (meq/L) e os anions $\mathrm{Cl}, \mathrm{HCO}_{3}$ e $\mathrm{SO}_{4}$ numa área selecionada de um mesmo tipo de rocha (granodioritos). O processamento foi feito com os métodos computacionais EXCEL e SURFER. Os resultados positivos desta primeira avaliação (Valdés González e Kimmelman e Silva, (a)1998) reforçaram a necessidade na procura de métodos computacionais mais especializados nesta área temática, úteis à revisão individual da qualidade do dado químico e à análise comparativa do conjunto de dados agrupados.

Foram analisados sob este enfoque os programas (softwares) a seguir: CHROMM, SAMA, SAPHIQ, WATEQF, WATSPEC, BALANCE, SIMUL, PHREEQE , HYDROWIN $~ A$ AQUACHEM.

Entre as dificuldades encontradas no conjunto dos primeiros sete programas estão:1) confecção da ficha exigida; 2) diferenças nos comandos para a mesma função; 3) nenhuma possibilidade de corrigir erros, obrigando repetir tudo desde o começo; 4) escassas possibilidades de melhorar a apresentação da impressão; 5) demora exagerada para o começo da impressão; 6) demora na execução dos comandos aplicados ou tanta rapidez que origina dúvidas sobre a certeza da execução do comando utilizado; 7) obtenção de resultados individualizados por pontos que obriga a sua comparação manualmente ponto por ponto e não permite a apresentação da sua distribuição espacial.

Estes detalhes no funcionamento dos programas citados (CHROMM, SAMA, SAPHIQ, WATEQF, WATSPEC, BALANCE e SIMUL) resultaram improcedentes para manobrar com grandes quantidades de dados, ainda que excelentes para quantidades muito reduzidas, em áreas de poucos quilômetros quadrados. Ótimos para estudos locais de contaminação.

O programa PHREEQE opera com o máximo possível das informações hidroquímicas existentes e por isso permite a modelação para diferentes alternativas espaciais e temporais a prognosticar, mas tem os defeitos indicados no parágrafo anterior, além da abundância de dados que pede para só avaliar um ponto. Os programas HYDROWIN e AQUACHEM (Calmbach, 1998) resultaram os mais indicados para o objetivo proposto. Na realidade, AQUACHEM é o programa HYDROWIN, melhor desenvolvido. 
Esta análise levou a utilização do programa AQUACHEM para o processamento global da documentação existente e PHREEQE para a modelagem particular naquelas áreas ou naqueles pontos que a informação obtida o permitisse. Sobre este último aspeto estava concebida a modelagem geral para áreas parciais utilizando o programa Ground Water Vistas (Rumbaugh, 1998). A utilização deste programa obedeceria às possibilidades de avaliar, a grandesamplitude, o sistema hidráulico deduzido a partir dos processamentos anteriores.

O principio utilizado para a confiança nos resultados dos processamentos dos dados com os referidos programas, foi a obtenção das estabilidades estatísticas dos valores avaliados, a partir da volumosa quantidade de dados preexistentes e a sua corroboração com a lógica do comportamento comparativo dos resultados e com os obtidos diretamente no campo. As esperanças da veracidade dos resultados sobre os quais fazer as conseqüentes interpretações, teve como principio matemático que "as correlações e suposições certas esperadas são dominadas pelas condicionantes das hipóteses estatísticas e a sua verificação" (Spiridonov e Lopatin,1973). O processamento preliminar fundamentou como hipótese estatística a existência de alguma lei de distribuição ou correspondência entre os parâmetros condutividade elétrica em $\mu$ icro-Siemens/centímetro $(\mu S / \mathrm{cm})$ e a concentração dos componentes em solução, se medidos em miliequivalentes/Litro (meq/L), com independência da sua procedência litológica. As condicionantes básicas seriam a regularidade estabelecida da procedência do tipo litológico das águas analisadas e a generalização de um equilíbrio estatístico na distribuição da composição química avaliada para as águas subterrâneas de cada um dos conjuntos litológicos analisados. Primeiramente encontrou-se alguns comportamentos característicos e mediveis entre as águas subterrâneas nos granodioritos da região de estudo (Valdés González e Kimmelmann e Silva, (a1998). Mesmo assim, devido a seu caracter ambiental destes componentes, foi também demonstrado que as águas com estas particularidades apresentavam-se concordantes com os lineamentos estruturais do terreno (Valdés González e Kimmelmann e Silva,(b1998).

Por estas razões, a estratégia do processamento encaminhou-se por caracterizar as águas subterrâneas amostradas nas formações geológicas documentadas. As formações geológicas a processar foram agrupadas atendendo as idades e representatividades dos eventos geológicos transcorridos na sua história.

\section{Considerações hidrogeológicas e hidrogeoquímicas}

As explicações anteriores conduzem a reconhecer que se devem conceber critérios e considerações particulares para a análise a desenvolver e que, pelas argumentações antecedentes, são ainda inexistentes no caso das águas minerais. É evidente que para as necessárias interpretações das identificações e manifestações do recurso hidromineral, a partir das águas subterrâneas comuns, exige-se manter as devidas especificações entre uma e outras. Qualquer uma das condições consideradas para a diferenciação expressa, e 
credibilidade hidrogeológica, deve obedecer e cumprir as leis físicas e químicas das águas no meio subterrâneo.

\subsection{O sistema hidrogeológico das águas minerais}

A água mineral é uma água subterrânea que obtêm as propriedades que a caracterizam através de processos físico-químicos e bacteriológicos no meio geológico pelo qual circula (Llamas, 1992). Extrapolar as considerações de "especiais", outorgadas pelos seus benefícios á saúde, ao campo do conhecimento hidrogeológico, ajuda pouco no estabelecimento das causas e associações particulares, não especiais, que dão origem a uma água diferente dentro das que estão ao seu redor. Com o fim de evitar confusões nas referências de um ou outro tipo de água, será considerado o termo de água comum ou subterrânea para todas as águas subterrâneas que não sejam águas minerais.

As águas minerais chegam à sua composição útil devido às particularidades encontradas no seu caminho até a sua aparição final (sejam poços ou mananciais). Mas não existe entrada nem recarga particular para águas minerais. A recarga é tão comum como das restantes águas subterrâneas. Pode se considerar que apenas uma parte da vazão total de recarga torna-se água mineral útil. Assim, apenas uma parte das águas comuns infiltradas, aparecerá no seu retorno à superfície (artificial ou naturalmente) como água mineral. Qual é a diferença entre a vazão de entrada e saída? Até hoje, a literatura especializada parece não ter resolvido esse importante parâmetro para a estimativa dos valores das reservas das jazidas de águas minerais. Por isso, qualitativamente pode se conceituar que uma parte da vazão total de água comum infiltrada $\left(Q_{\mathrm{CE}}\right)$, será transformada em vazão de água mineral. Será uma vazão parcializada $\left(Q_{M E}\right)$. Resulta evidente que $Q_{C E}-Q_{M E}=Q_{C S}$ (vazão de saída da água comum que pode se igualar à $Q_{C E}$ nos casos de estimativas de reservas, quando a água mineral não é o alvo da avaliação. $\left(Q_{M E}=0\right)$. Esta vazão $Q_{M E}$ circulará pelos caminhos mais dificultosos condicionando a intensificação das interações água/rocha, originando aquela composição mineral singular, útil. A água infiltrada, agora já mineral, e dentro de um caminho de circulação especializado (pode ser mais profundo, ou mais vagaroso que as águas comuns acompanhantes), alcançará a superfície como vazão de saída, $\left(Q_{M S}\right)$, apoiado pelas facilidades que nessa trajetória podem oferecer-lhe as intercepções com maiores permeabilidades (falhas, gretamentos, contatos litológicos ou tectônicos) ao potencial acumulado no líquido até esse intercepto (temperatura, densidade, concentração de sais, concentração de gases e pressão hidráulica elevada). Que parte de $Q_{M E}$ é $Q_{M S}$ ? Resulta mais uma interrogante necessária para a avaliação quantitativa destes recursos. Mas, pode se conceituar, para os fins avaliativos iniciais, $Q_{M E}$ $=Q_{M S}$, onde $Q_{M E}$ e $Q_{M S}$, indicam os valores totais das vazões de formação e drenagem do tipo de água mineral sob estudo. É um princípio conceptual que reforça os critérios hidrogeológicos para a avaliação dos recursos hidrominerais, a seguir: 
-A vazão total de recarga na área total de recarga das águas subterrâneas é maior que a vazão das águas minerais, $Q_{M E}\left(Q_{C E}>Q_{M E}\right)$. Será igual apenas para condições muito bem conhecidas.

-A vazão total de drenagem na área total de drenagem das águas subterrâneas é maior que a vazão de drenagem das águas minerais, $Q_{M S}\left(Q_{C S}>Q_{M S}\right)$. Mesma observação que para o ponto anterior.

-Como as águas minerais avaliam-se a partir de fontes ou poços, deve-se considerar que a sua vazão, $Q_{M S}$, mantém todas as qualidades da água mineral invariáveis. Conhecendo o possível valor , $Q_{M E}$, podem reajustar-se os valores do necessário equilíbrio, onde $Q_{S M}$ deve ser menor ou igual de $Q_{M E}$.

A igualdade anterior implica considerar a formação da água mineral, relacionado com as águas subterrâneas comuns acompanhantes, como um sistema fechado enquanto às particularidades dos seus processos de formação, devido terem outros valores de cumprimento das leis físico-químicas operantes no meio geológico subterrâneo. A consideração de separar às águas minerais como um sistema de formação independente das águas comuns, não assume a existência de leis diferentes para elas. Assume intensidades diferentes às mesmas leis operantes no subsolo, a partir que a trajetória faz-se diferente às águas comuns infiltradas, sob as mesmas condições de recarga.

O fato que uma jazida de água mineral ser captada através de poços não modifica nada estas conceições aqui enunciadas, apenas altera as condições naturais da sua saída. A explotação não cumprindo que $Q_{M E}=Q_{M S}$, condicionara a perda da alguma das suas propriedades características (Valdés González \& Kimmelmann e Silva, (c) (1998).

Como estes caminhos especializados não são condutos fechados na trajetória subterrânea, existem diferentes gradações entre a mineralização das águas comuns e das águas minerais que podem se manifestar mesmo na superfície como na profundidade (Valdés González \& Kimmelmann e Silva, .(b),1998).

A consideração do que a vazão de recarga de água mineral, $Q_{M E}$, iguala-se à vazão de saída das águas minerais, $Q_{M S}$, a partir de uma infiltração comum total, $Q_{C E}$, implica que também existe uma igualdade equivalente da vazão de saída da água subterrânea comum, muito utilizadas nas estimativas de reservas. A diferença básica nestas igualdades está em que entram ao mesmo tempo os dois tipos de vazões, mas as saídas entre as águas comuns e minerais, tem um retardo com respeito à entrada original. Isso significa que os fatores que afetam a zona de recarga (quantidade e qualidade da água superficial recarregada) apresentam os seus resultados primeiro nas águas subterrâneas comuns e logo nas águas minerais, pudendo esse "logo" ser equivalente à faixa entre algumas unidades e milhares de anos.

Tais diferenças na repercussão das variações das condições de recarga entre a água comum e a mineral exigem considerações diferentes entre uma e outra para avaliar a gênese, estabilidade da qualidade da água e a vazão de exploração, mesmo assim, problemas relacionados com qualquer contaminação, sobre tudo de poluentes não biodegradáveis, cuja permanência pode durar o mesmo tempo da água mineral mais antiga. 
Todo o argumentado permite fundamentar que a abordagem particularizada das águas minerais num estudo regional hidrogeoquímico, precisa distinguir as suas apresentações diferenciadas entre as águas subterrâneas comuns, ainda que coincidam ambas águas na mesma área e no mesmo tempo de coleta das amostras, para assim analisar as possibilidades das suas procedências e interpretar as causas da sua distribuição no território avaliado. Estudar e interpretar o desenvolvimento e manifestação das águas minerais como um sistema hidrogeológico diferente e particularizado das águas subterrâneas comuns é mais um dos critérios assumidos.

\subsection{Parâmetros Hidrogeoquímicos indicadores}

A consideração de um sistema hidrogeológico particular das águas minerais permite também analisar os processos físico-químicos e bacteriológicos que as originam como resultados especializados dentro do conjunto total dos processos que operam com as águas comuns.

Uns dos resultados do processamento preliminar dos dados preexistentes, foi o uso das relações entre Condutividade $(\mu \mathrm{S} / \mathrm{cm})$ e concentração de Cloretos (meq/L) para a identificação de águas mais velhas ou provenientes de formações geológicas mais antigas (Valdés González e Kimmelman e Silva, (a), 1998)

Outros autores têm utilizados caminhos similares para obter alguma outra identificação das águas. Entre autores anteriores que utilizaram esse enfoque podem ser mencionados: Fagundo (1990) ; (1996); Fagundo, Valdés e Rodriguez (1996) que utilizam as relações entre concentração iônica (Ci) (meq/L) e condutividade $(\mathrm{Ce})(\mu \mathrm{S} / \mathrm{cm})$ na procura de parâmetros hidroquímicos nas águas kársticas. Examinando as suas argumentações e exemplos não podemos afirmar que foram obtidas as mesmas conclusões que o autor, apesar de partir de considerações similares.

Fagundo, Valdés e Rodriguez, 1996, estabelecem uma correspondência linear entre $\mathrm{Ci} / \mathrm{Ce}$ para $\mathrm{HCO}_{3}, \mathrm{Ca}$ e $\mathrm{Mg}$ e outra correspondência quase parabólica entre os $\mathrm{Ci} / \mathrm{Ce}$ de $\mathrm{HCO}_{3}, \mathrm{Ca}$ e $\mathrm{Mg}$ com o tempo, para um calcário e um dolomito, respectivamente, todas obtidas em experimentos de simulação no laboratório. Fagundo (1996) apresenta um gráfico de $\mathrm{Ci} / \mathrm{Ce}$ para $\mathrm{HCO}_{3}, \mathrm{Cl}$, $\mathrm{SO}_{4}, \mathrm{Ca}, \mathrm{Mg}$ e $\mathrm{Na}+\mathrm{K}$ das águas que circulam pelos calcários da formação geológica Guaijabón, Cuba, que aparentam correspondências lineares significativas, onde são agrupados todos os pontos num só gráfico, mas quando se observam detalhadamente os diferentes pontos grafados, pode se apreciar também alguma dispersão entre os pontos de um mesmo elemento.

Particularmente, no processamento da presente pesquisa utilizaram-se também os dados preexistentes das águas dos calcários do Neogeno (Formação Guines) em similar quantidade de análises das correspondências, surpreendeu que a correlação com respeito à condutividade do $\mathrm{Cl}$ fosse maior que do $\mathrm{HCO}_{3}$, pois se supunha que devia se manifestar ao contrário. No capítulo Resultados serão estabelecidas as causas destas diferenças com os resultados do autor. 
Tal correspondência maior da condutividade com o cloreto que com o bicarbonato não significa que as águas que circulam por esta formação calcária não sejam bicarbonatadas, como certo é seu conteúdo superior de carbonatos de cálcio. Também não obrigam que tenham que ser cloretadas pela sua correlação maior. O que esta correspondência constata é que a diluição do cloreto é maior, ainda que a sua quantidade total no líquido seja menor. O cloreto tem um grau de dissociação muito maior que o bicarbonato (Jrupalo, Bucreev, 1965; pp 24-25).

As afirmações desses citados autores e o uso dos resultados dessas pesquisas tenham foram aplicadas especificamente nas águas de baixas salinidades dos calcários. As diferenças entre as conclusões daqueles autores e as conclusões obtidas nesta pesquisa é que os resultados deste projeto foram tirados dos enfoques e interpretações dos seus próprios processamentos. Um outro aspeto a considerar é que esta pesquisa processou dados provenientes das águas em circulação por diferentes meios litológicos (ígneos, metamórficos e sedimentares) onde a homogeneidade é pouca. Os resultados de correspondências tenderam a certa regularidade com respeito às correlações entre cloretos e a condutividade.. Tais tendências ainda não podem ser consideradas leis da Natureza se não fossem estruturadas dentro do seu sistema hidrogeoquímico correspondente, e devem ser adequadas segundo outras correspondências do processo hidrogeológico. É muito provável, e está dentro dos propósitos da pesquisa definir, que o grau de correspondência entre o cloreto e condutividade relaciona-se com o tempo da circulação subterrânea, que pode associar-se às mais duradouras condições de diluição.

Entre outros aspetos ou fatores que os hidrogeológos procuram associar para obter algo pelo qual dominar as generalizações do comportamento das águas subterrâneas estão o $\mathrm{pH}$ e o Redox ,ou potencial de oxidação (Eh). O primeiro da valores a acidez e alcalinidade das águas e, segundo o valor do $\mathrm{pH}$, as substâncias diluem-se ou precipitam-se. Mas, tal concentração de uma ou outra substância não só depende do $\mathrm{pH}$, senão também do valor do Eh. Para confirmar um ou outro ion em solução ou não, utilizam-se os gráficos de $\mathrm{Eh} / \mathrm{pH}$, muito abundantes na literatura especializada. Estes gráficos têm sido muito úteis para as análises de contaminação, sobre tudo, devidas às atividades da mineração e outros efluentes poluidores das águas superficiais e subterrâneas (Mackay and Cherry, 1989; Srasek, 1998; Shinobe and Srasek, 1997).

Outros autores utilizam o Redox como uns dos parâmetros de caracterização das águas subterrâneas (Allen, Perdue and Brown, 1993; Fagundo, Valdés y Rodriguez, 1996; Matthess, 1982; Gascoyne, 1997; Schuartz, 1994).

Todos coincidem que o parâmetro Eh não está entre os mais medidos nos trabalhos hidrogeológicos de campo. Apesar disso, Allen et al, 1993, aponta que as águas subterrâneas podiam ter nas características do Redox e Ph uma avaliação similar à caracterização das águas do perfil do solo. Mas, de outra parte, Schuartz, 1994, considera "A dificuldade para generalizar a condição Redox em águas subterrâneas é que os fatores variam de um lugar para outro". 
Entre estas duas opiniões extremas, o autor considera que o Redox caracteriza a variação de fatores de um lugar a outro, pois caracteriza as condições gerais do ambiente da procedência ou circulação das águas subterrâneas. As dificuldades podem surgir pelo modo como se analisa ou considera-se o valor recebido com respeitos à hidrogeologia da área de estudo. O Redox não é um valor matemático invariável, é um valor que caracteriza o valor resultante das energias em evolução das sustâncias em solução, por dissolver ou precipitar. Evidentemente, a literatura especializada individualiza os valores dos potenciais (em + ou - milivolts ou volts) de duplas de Redox (as diferentes formas de dissolução dos elementos com a água) e os apresenta em tabelas (Mason, 1960; Jrupalo and Bucreev, 1965) e gráficas relacionadas, principalmente, com o valor de $\mathrm{Ph}$ (Brookins, 1988). Todos explicam que estes valores são para umas determinadas condições de $\mathrm{pH}$ e grau de solubilidade, e que representam valores guias de correspondências com o ambiente da formação e composição das águas numa condição específica de dissolução. Allen et al, 1993, apresenta um gráfico que relaciona os valores teóricos das duplas Redox com os valores Eh medidos no campo em águas naturais. No referido gráfico pode ser constatado a existência de uma média entre os valores calculados teoricamente das duplas Redox e os resultados obtidos no campo. Daí a existência de tabelas e gráficos relacionando Eh/pH para algumas reações (Mason, 1960, Fig. 32, pp 183) e para cada reação individual (Brookins, 1988). Neste aspecto, pela sua importância nas águas aparecem individualizados estes gráficos para as águas naturais (Mason, 1960, Fig. 33, pp 185; Allen et al, 1993, Fig. 1, pp 77; Brookins, 1988, Fig. 1, pp 11). Nestes gráficos indicam-se as zonas que correspondem aos ambientes de oxidação, redução e intermédios ou transicionais em dependência com os valores resultantes $\mathrm{Eh} / \mathrm{pH}$ de cada uma dupla Redox. Estes gráficos padronizados são de grande utilidade quando se quer conhecer quais podem ser as condições do ambiente subterrâneo onde se formaram as águas captadas na superfície, sejam por poços ou mananciais. Tal informação, unida à geologia e petrografia da jazida e a sua composição química total da água, permitem agrupar elementos favoráveis de análises para a interpretação da gênese das águas subterrâneas e minerais.

Ainda que autores como Gascoyne, 1997, tenham sido muito exigentes para a caracterização e medição do Eh no campo para evitar variação entre o valor original e o valor representativo da profundidade de procedência da água estudada, tudo parece indicar que estas variações podem acontecer nas águas ao transitar de um méio de oxidação ao outro. Pode acontecer que as águas de profundidade repitam ainda as características do seu meio de oxidação á sua saída em superfície.

Se não fosse por isso, todas as águas medidas deveriam ter o valor de Redox representativo das águas do ambiente de oxidação superficial, resultado que não acontece, pois pode se afirmar que poucas águas subterrâneas são medidas nas suas profundidades de formação. No trabalho de campo efetuado mediram-se os Eh nos pontos de coleta de amostras e os seus valores não corresponderam apenas às zonas de oxidação. 
O uso dos valores do Redox das águas minerais para a interpretação do seu meio de formação, o relacionamento destes valores com a composição química dessas águas e a possibilidade de utilizar estes valores para uma análise mais detalhada, podem resultar em contribuição à interpretação dos processos hidrogeoquímico que acontecem em determinadas zonas da circulação subterrânea. Infelizmente a quantidade conseguida de valores do REDOX não foi suficiente para a possibilidade de comparação com os demais valores hidrogeoquímicos.

\subsection{Considerações geológicas}

No item 4.3 estabeleceumse que o fundamento do processamento dos dados precisava regularizar alguns aspetos dos processos a interpretar. Neste sentido argumentou-se as considerações hidrogeológicas e hidrogeoquímicas a utilizar para os objetivos da Tese.

A geologia cubana, geral e particular, da região de estudo será abordada no próximo capitulo. Neste item analisaram-se aqueles aspetos fundamentais utilizados para manter a unidade e regularidade interpretativa da informação total. Conseqüente com as considerações apresentadas, é apenas o meio geológico o que estabelecera as particularidades do fluxo circulante.

A historia geológica cubana começa nos finais do período Jurássico com intrusões magmáticas dentro a plataforma existente na bacia caribenha (Iturralde Vinent, 1994). Manifestações de diferentes intrusões, sedimentos vulcânicos, clásticos e químicos estão presentes refletindo os processos de características ígneas, metamórficas e sedimentares ocorridas, através das estruturas e distribuição atual das diferentes formações geológicas presentes.

No Neógeno (Mioceno) cujas formações iminentemente carbonatadas ocupam quase o $60 \%$ do território atual cubano, estavam sob o mar, não aparecendo uma nítida afirmação sobre até onde existiam os terrenos emergidos. Por isso, considerou-se a existência total da área cubana emergida a partir do Pleistoceno. Esta inferência é feita para estabelecer um tempo comum onde as precipitações começaram a se infiltrar no sobsolo cubano. Ainda que possa ser precisado mais para frente, a idade geral para ás águas subterrâneas, pela potencialidade do tempo da circulação, será considerada, como máximo, menor que 2000000 anos, quando termina o Terciário. Isso significa que as condições favoráveis para dar origem às águas minerais por infiltração das águas das precipitações não devem ter existido para a totalidade do território emergido sob estudo, antes desse tempo. Também pode se conceber a possibilidade da existência de águas ainda mais velhas a partir da infiltração das águas marinhas nas partes submergidas, já consolidadas, antes do período indicado. Mas, como tal probabilidade não permite um limite certo sobre o começo do período e podesse se misturar conceitualmente com as águas conatas, o autor prefere assumir o primeiro limite e reservar tais probabilidades até que os resultados e interpretações admitam-no ou fundamentem outra possibilidade. 
As águas circulam por terrenos formados em diferentes tempos e condições ou período suficiente como para que o fluxo geral de entrada para a formação de águas minerais $\left(Q_{M E}\right)$ pudesse se equilibrar com o fluxo correspondente de saída $\left(Q_{M S}\right)$. Nesse mesmo sentido, os indicadores hidrogeoquímicos utilizados, se analisados nas águas subterrâneas circulando pelas formações geológicas representativas das diferentes idades da história geológica cubana, devem estar equilibrados com a ação continuada dos múltiplos processos físico-químicos e bacteriológicos operando no sistema hidrogeológico das águas minerais.

O conjunto das considerações argumentadas visou estabelecer critérios básicos, regularizados para o nivel da informação existente que permitisse analisar uma hipótese de trabalho comum aos resultados da região estudada.

A hipótese com a qual estabeleceu-se o processamento efetuado da informação existente foi que: se os dados das águas subterrâneas que foram obtidas nos aqüiferos medidos, ordenados pelas idades e grupos litológicos da sua história geológica, são analisados similarmente na sua tipologia hidrogeoquimica e nos seus comportamentos com respeito ao cloreto, devem refletir algumas particularidades devidas ao maior tempo de circulação, apesar das suas diferenças ou similitudes litológicas. Tais particularidades devem também ser refletidas, se analisada a sua distribuição espacial na superfície do território, nas estruturas ou contatos tectônicos existentes.

Deve-se esclarecer que a hipótese é derivada dos resultados dos processamentos e interpretações iniciais, mesmo cartográficos como dos granodioritos, que foram explicados neste capitulo. 


\section{IV ÁREA DE ESTUDO}

\section{1. Área de Estudo Sensu Lato}

A área de estudo encontra-se no território da República de Cuba, o maior arquipélago do Mar do Caribe, com uma área total $110922 \mathrm{~km}^{2}$, constituídas seguintes ilhas: 1) Ilha de Cuba com $105007 \mathrm{~km}^{2}$; 2) Ilha da Juventude (antiga Ilha de Pinhos), $2200 \mathrm{~km}^{2} \mathrm{e}, 3$ ) rochedos adjacentes, $3715 \mathrm{~km}^{2}$. Na Figura 1 esta representada a localização geográfica da República de Cuba.

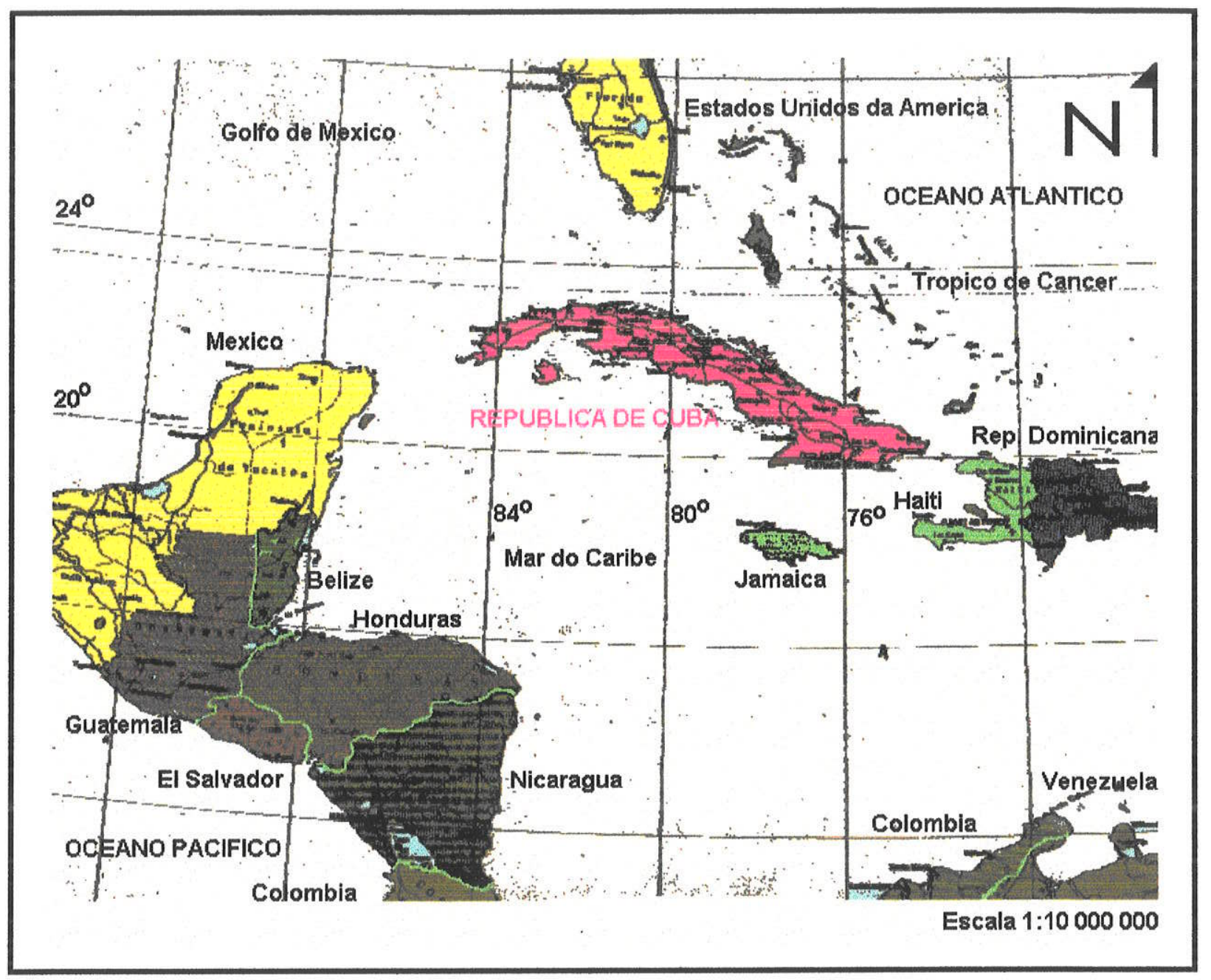

Figura 1. Localização geográfica da República de Cuba.

(Fonte: Núñez Jiménez et al, 1970)

\subsubsection{Aspectos Geográficos:}

Cuba esta localizada entre os meridianos:

-Extremo setentrional:

Cayo Cruz del Padre $\left(23^{\circ} 17^{\prime} 09^{\prime \prime}\right.$ latitude N e $80^{\circ} 53^{\prime} 55^{\prime \prime}$ longitude O de Greenwich) 
-Extremo meridional:

Punta del Inglés $\left(19^{\circ} 49^{\prime} 36^{\prime \prime}\right.$ latitude N e $77^{\circ} 40^{\prime} 36^{\prime \prime}$ longitude $\mathrm{O}$ de Greenwich)

-Extremo oriental:

Punta del Quemado $\left(20^{\circ} 12^{\prime} 36^{\prime \prime}\right.$ latitude $\mathrm{N}$ e $74^{\circ} 07^{\prime} 52^{\prime \prime}$ longitude $\mathrm{O}$ de Greenwich)

-Extremo ocidental:

Cabo de San Antonio $\left(21^{\circ} 51^{\prime} 40^{\prime \prime}\right.$ latitude N e $84^{\circ} 57^{\prime} 54^{\prime \prime}$ longitude O de Greenwich)

Os países de América, mais perto de Cuba são: Estados Unidos de América do Norte, $180 \mathrm{~km}$ a norte; Jamaica, $140 \mathrm{~km}$ a sul; Haiti, $77 \mathrm{~km}$ a este, e México, $180 \mathrm{~km}$ a oeste.

O território cubano é dividido politicamente em 14 províncias mais o Município Especial da llha da Juventude ( Figura 2 ).

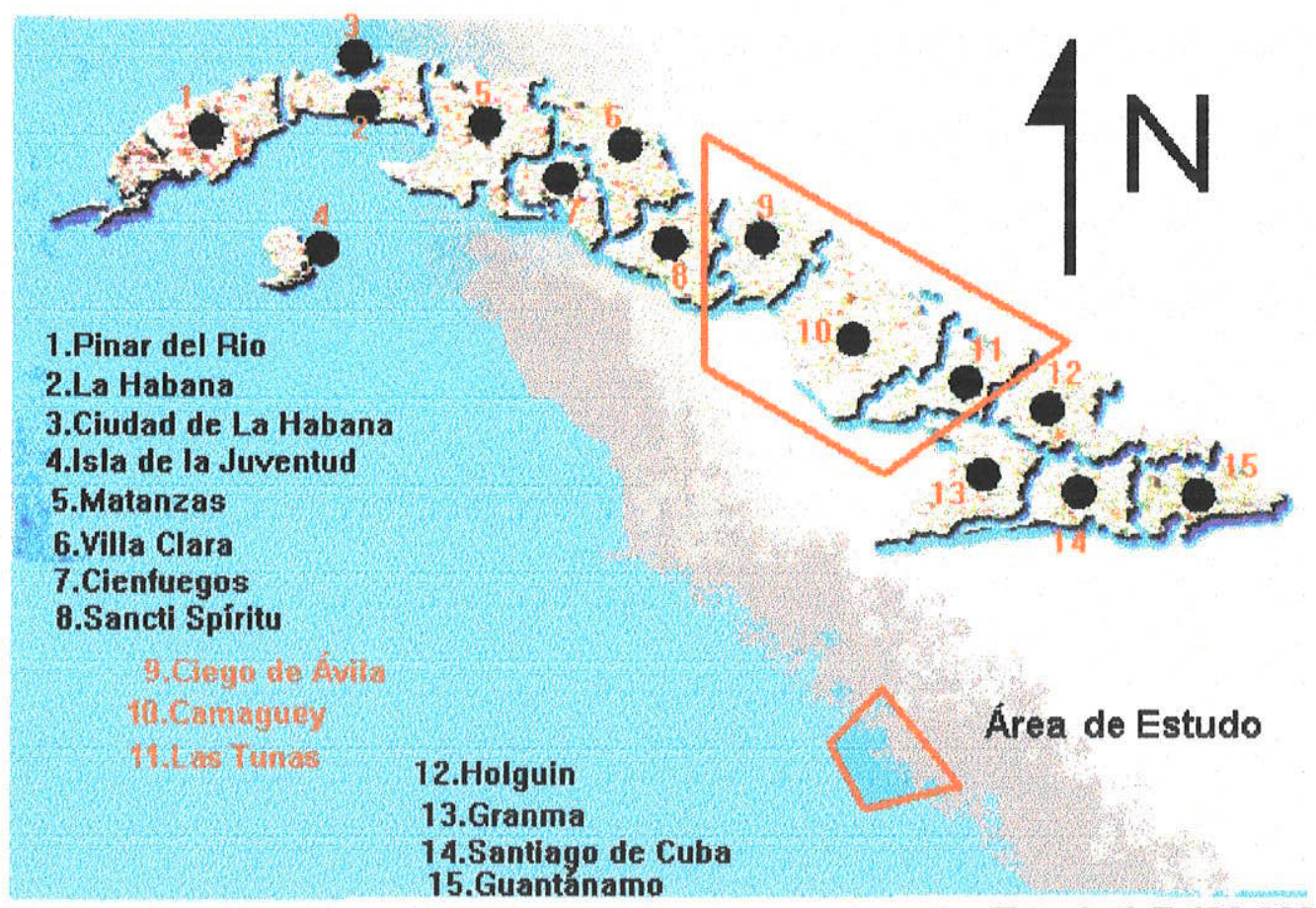

Escala 1:7 400000

Figura. 2 Divisão Política da República de Cuba. (Fonte : Jané Martin, 1998)

A ilha de Cuba, onde se encontra a área de estudo, tem $3209 \mathrm{~km}$ de costa norte e $2537 \mathrm{~km}$ de costa sul. 
A maior cadeia montanhosa é a Sierra Maestra, na província de Santiago de Cuba, com o Pico Turquino de $1974 \mathrm{~m}$. sobre o nível médio do mar.

O clima é tropical úmido. A precipitação média anual é de $1384 \mathrm{~mm}$ com mínimas de $276 \mathrm{~mm}$ no período de estiagem (novembro-abril) e $1104 \mathrm{~mm}$ no período chuvoso (maio-outubro). A temperatura média anual do ar é de 25,5 ${ }^{\circ} \mathrm{C}$ com mínimas de $22,5^{\circ} \mathrm{C}$ no mês mais frio (janeiro) e máximas de $27,8^{\circ} \mathrm{C}$ no mês mais quente (agosto).

Do ponto de vista geológico, Cuba conforma o modelo tectônico de placas para o Caribe Ocidental, fundamentado por Iturralde-Vinent et al, 1994, e constituida por dois elementos estruturais principais: a Faixa Dobrada e o Neoautóctono .

A primeira subdivide-se em Unidades Continentais e Unidades Oceânicas, enquanto ao Neoautóctono pertencem os sedimentos pouco dobrados do Eoceno Superior até hoje. As Unidades Oceânicas estão constituídas pela Faixa Ofiolítica do Norte e o Arco Vulcânico do Cretáceo, bem representadas na região Centro-Oriental. As rochas ígneas, gabros e peridotitos, e metamórficas, serpentinitos, do Complexo Ofiolítico são as mais antigas, de idade Triásico-Tardía ao Cretácico inferior. Ao fim do Cretácico superior, Maestrichtiano, ocorreram as atividades geológicas que levaram à formação de sedimentos clásticos, químicos e vulcânicos com atividades intrusivas ácidas até pouco ácidas, granitos, granodioritos, andesitos e gabros, e que determinam as estruturas conhecidas do Arco Vulcânico. Após a atividade vulcânica seguiu a deposição de sedimentos terrígenos e químicos, como principais, calcários, até o Quaternário.

\section{2. Área de Estudo Sensu Stricto (Cuba Centro-Oriental)}

A área de estudo, propriamente dita, a região de Cuba Centro-Oriental, compreende as províncias de Ciego de Ávila, Camaguey e Las Tunas, abrangendo uma superfície de $27000 \mathrm{~km}^{2}$ (Figura 2).

\subsubsection{Geologia}

Para uma melhor compreensão do desenvolvimento geológico cubano particularizado na área de estudo, é conveniente detalhar mais um pouco os aspectos relacionados com as unidades estruturais mencionadas e a suas manifestações e relações espaciais, litológicas e estratigráficas dentro da região sob análise. Neste sentido, serão detalhadas apenas as formações geológicas que formarão parte básica do processamento e análises efetuado no presente documento, e das quais o autor faz referências específicas nos mapas das figuras apresentadas. 


\subsubsection{Descrições das Unidades Geológicas principais}

\section{A Faixa Dobrada}

\subsection{Unidades Continentais}

Ao norte de Cuba encontram-se elementos geológicos reconhecidos como o Bloco estreito de La Florida. Estas rochas representam o embasamento com sedimentos do Jurássico até Cretáceo Inferior (Aptiano). O referido embasamento aflora parcialmente entre as províncias de Matanzas (Playa Menéndez, Socorro e Sierra Morena). Esta representado por mármores e metasilisiclásticos de idade Neoproterozoico, atravessados por pequenos corpos de granitos do Jurássico Médio. Esta coberto por materiais terrígenos e carbonatados do Jurássico Tithoniano.

Sobre esse embasamento, na área Cuba Norte-Bahamas se desenvolveu inicialmente em condições epicontinentais uma seção constituída por rochas silici-clásticas do Triássico Tardio? ao Oxfordiano? Estas rochas afloram como fragmentos nas brechas dos diapiros sulinos de Turiguanó, Punta Alegre(Ciego de Ávila) e San Adrián. Nestas mesmas localidades afloram a seção suprajacente representadas por evaporitas (anhidritos, halitos, calcitos e dolomitos) do Jurássico Superior, provavelmente do Oxfordiano ao Kimmeridgiano. Sobre estes evaporitos sobejasem dolomitos, anhidritos, gessos e halitos dos depósitos platafórmicos do Kimmeridgiano ao Aptiano.

Mais para o sul, dispõe-se a seqüência chamada Zona de Remedios, constituída por mais de $2000 \mathrm{~m}$ de calcários e dolomitos de águas pouco profundas de idade Aptiano-Maestrichtiano. As rochas estão intensamente deformadas, com falhas trans-correntes e dobramentos apertados.

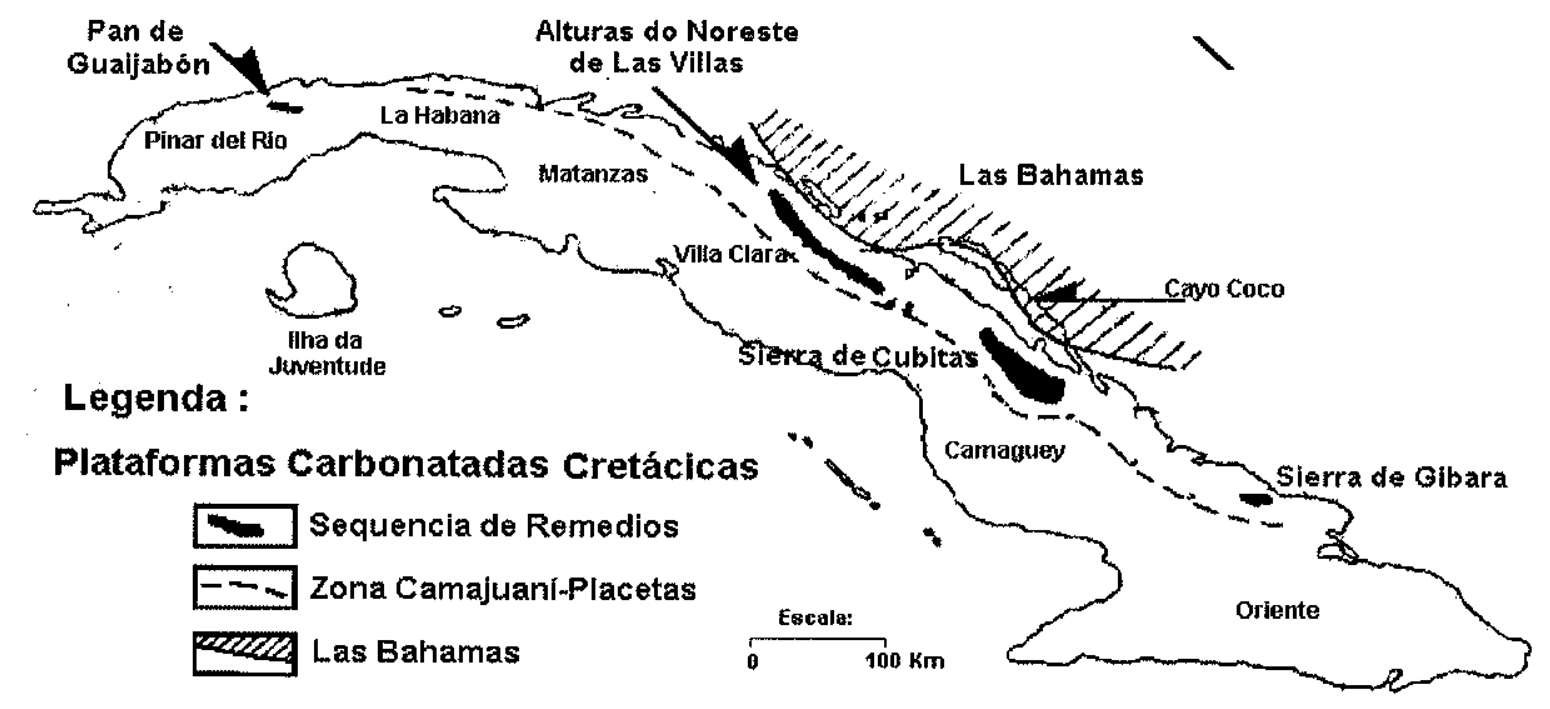

Figura 3 . Distribuição das Zonas de Plataformas pertencentes às Unidades Continentais relacionadas com Cuba.

(Fonte: Iturralde-Vinente, 1994) 
No território cubano as rochas correspondentes à Zona Remedios, afloram nos maciços carbonatados localizados nas alturas do noreste de Las Villas, na Sierra de Cubitas (Camaguey) e na Sierra de Gibara, assim como nos seus possiveis equivalentes de Pinar del Rio (Pan de Guajaibón) e Província de Guantánamo (Figura 3 ).

\subsection{Unidades Oceânicas}

Os ofiolitos, as associações do Arco Vulcânico e os sedimentos superpostos a eles podem se agrupar como unidades geológicas de natureza oceánica. Elas são muito comuns no território de Cuba e estão representados pelos ofiolitos da faixa setentrional, 0 arco vulcânico cretácico, a costra oceánica infra-arco vulcânico, o arco vulcânico paleogénico e as bacias sedimentárias superpostas. A costra oceánica infra-arco vulcânico e o arco vulcânico paleogénico não tem representação na área de estudo.

\subsection{Ofiolitos da Faixa Setentrional}

Estas rochas afloram como uma série de corpos alongados na metade setentrional da llha de Cuba, entre Cajálbana e ao oeste e Baracoa ao este. Formam mantos tabulares muito desmembrados, onde as rochas estão intensamente deformadas e alcançam até $6 \mathrm{Km}$ de espessura. Os corpos dos ofiolitos durante 0 seu estabelecimento misturaram-se com escamas tectônicas do Arco Vulcânico do Cretáceo (Figura 4).

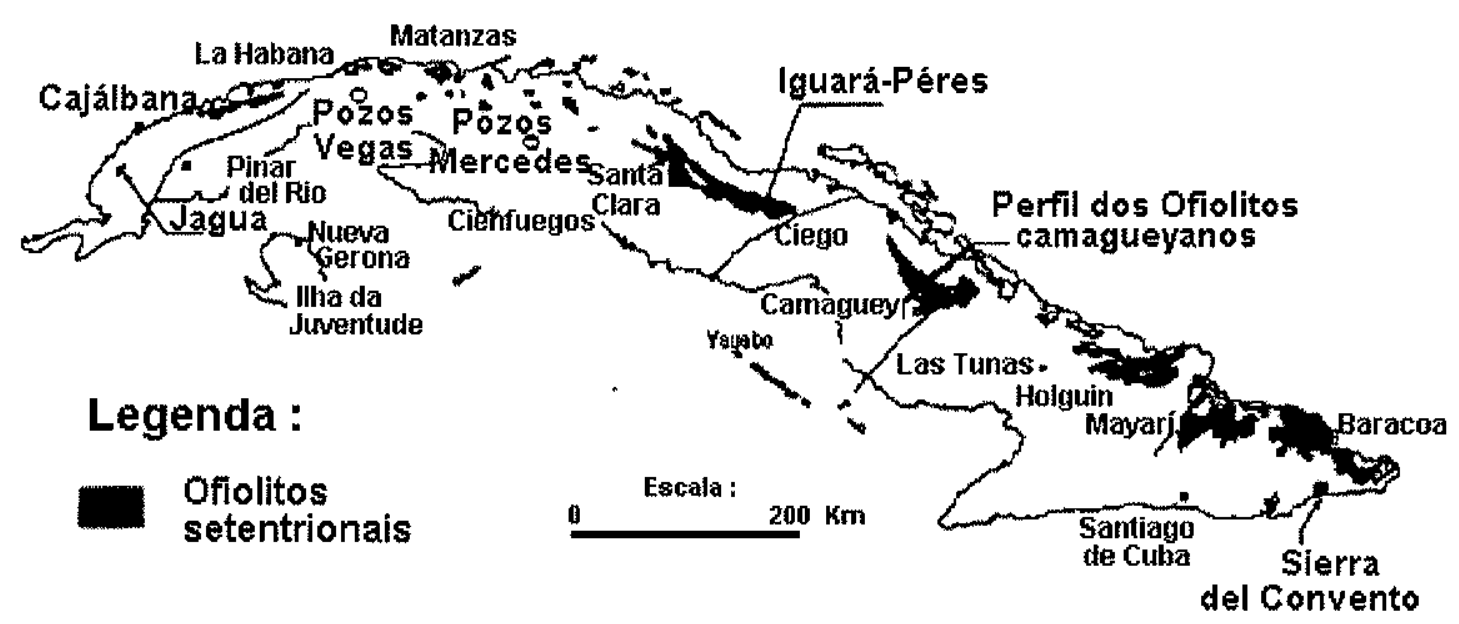

\section{Figura 4. Distribuição do Complexo Ofiolítico em Cuba.} (Fonte : Iturralde-Vinente, 1994)

Os ofiolitos que se estendem entre La Habana e Holguin jazem sobre a Plataforma das Bahamas e são cobertos pelo Arco Vulcânico, vide Figura 5. Neste perfil, como em outras partes da faixa setentrional, o alóctone ofiolítico setentrional esta duplicada. 
Horte

Profundidade

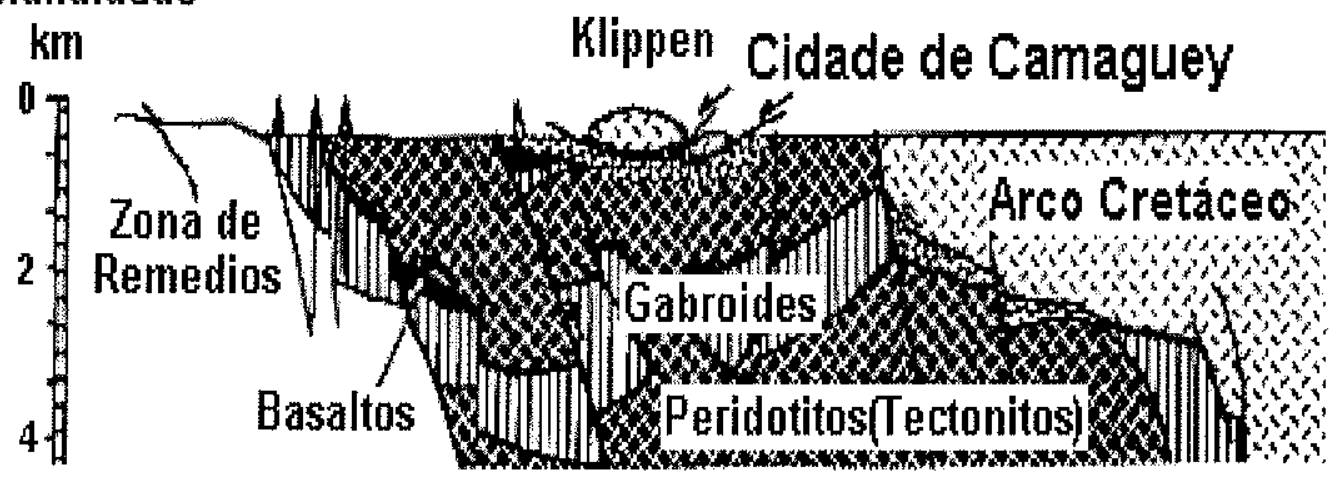

Legenda :

\section{Figura 5 . Perfil do Complexo Ofíolítico de Camaguey.}

(Fonte : Iturralde-Vinente, 1994)

Os ofiolitos setentrionais apresentam um corte completo, com representantes dos complexos peridotíticos, transicionais e cumulativos de idades Triássico tardio até Cretáceo Inferior.

$\mathrm{Na}$ composição dos ofiolitos entram rochas que apresentam diferenças genéticas e petroquímicas que permitem agrupá-las em três complexos com as suas composições petrográficas particulares:

1) Complexo Peridotítico (Tectonitos): harzburgitos, em menor grau, websteritos e herzolitos, com bolsões isolados de dunitos, todos serpentinizados. Raras vezes diques de Gabro.

2) Complexo Transicional: harzburgitos, websteritos e herzolitos, com bolsões e bandas duníticos, todos serpentinizados; gabroides e pegmatitos.

3) Complexo Cumulativo: grupos máficos (gabros, olivinos, noritos, troctolitos e anortositos) e ultramáficos, harzburgitos, websteritos e herzolitos e raros dunitos, todos serpentinizados. 


\subsection{Arco Vulcânico do Cretáceo}

Varias unidades litoestratigráficas pertencem às seqüências do Arco Vulcânico do Cretáceo. A idade pode se restringir ao Aptiano-Campaniano Médio, e jazem discordantes sobre os depósitos das formações Durán e Presa Jimaguayú, do Campaniano Tardio ao Maestrichtiano. O quimismo do conjunto é calcoalcalino.

A seguir serão descritas as formações do Arco Vulcânico analisadas para o processamento hidrogeoquímico:

\section{Formação Caobilla}

Esta distribuída principalmente ao norte das formações Camujiro e Piragua. Constitui uma fácies análoga à da Formação Camujiro, só que mais ácida, provavelmente da mesma idade da Formação Piragua.

A Formação Caobilla são tufas e lavas de composição ácida e média ácida, de origem submarina e subaérea. Nos cortes raramente podem se estabelecer os elementos do depósito, pois as lavas e tufas, com poucas exceções, formam corpos maciços. A espessura desta formação não pode ser determinada diretamente, devido ao seu caracter maciço, com transformações metasomáticas e presença de intrusivos na sua base, quando não esta alóctone sobre os ofiolitos. Supõe-se uma espessura da ordem dos $500 \mathrm{~m}$.

Estabele-se a sua idade, tentativamente, como Coniaciano (?)-Santoniano ao Campaniano. Pode se supor uma idade mais antiga do Aptiano-Albiano.

\section{Formação Contramaestre}

A sua área abrange a parte suloriental da província Camaguey, entre Vertientes-Cuatro Compañeros e Jobabo. Esta formada por uma série de rochas sedimentárias, homogêneas, piroclásticas, organôgenas e vulcânicas. Caracteriza-se pela sua variabilidade lateral, diferenças na composição dos pacotes de rochas e em parte pelo seu grande volume estratigráfico. A espessura, sobre a base dos diferentes membros, alcança o valor dos 8000 $\mathrm{m}$. ao NE e entre 10500 e $13250 \mathrm{~m}$ ao SO.

A idade tem sido muito difícil de determinar devido a sua grande difusão. Estima-se por dados faunísticos do Coniaciano-Santoniano? e pela sua posição estratigráfica $e$ as suas relações laterais, que deva ser do Turoniano?-Coniaciano? ao Campaniano Inferior.

\subsection{Complexos Plutônicos e Metamórficos}

As rochas efusivas-sedimentáres do arquipélago vulcânico Cretácico estão amiúde atravessadas por plutonitos de composição muito variada. A estas intrusões associam-se distintas rochas metamórficas originadas por alterações de contacto e hidrotermal metasomáticas tardias. 
Os afloramentos mais extensos de plutonitos cretácicos apresentam-se por $400 \mathrm{Km}$ entre Cumanayagua (sudoeste de Santa Clara) e Buenaventura ao sudoeste de Holguin. $O$ fato de que na atualidade aflorem como exposições isoladas, aparentemente sem relação direta, deve-se a que o seu teto esta distintamente erosionado e em parte, coberto por sedimentos mais jovens. Neste complexo estão os granitos e granodioritos.

Estas rochas plutônicas dividem-se em:

-Série calcoalcalina sódica.

Tem um desenvolvimento areal limitado, em Villa Clara e em Camaguey.

-Série alcalina.

Apenas é conhecida na área de Camaguey. Esta composta por um conjunto de rochas gabro-sieníticas, onde se caracterizam os sienitos biotitohornebléndicos de granulação grossa, associados a corpos pequenos e diques de sienitos quartzíferos.

-Série calcoalcalina normal.

Ocupa a maior área de pesquisa. Estas são rochas do conjunto tonaliticogranodiorítico, representado por uma fase inicial de dioritos quartzíferos, monzodioritos e raramente gabro-dioritos; uma fase principal de tonalitos, granodioritos, e em grau menor, monzonitos quartzíferos e granitos biotíticoshornbléndicos, e a fase final, pequenos corpos e diques de granitos biotíticos leucocráticos.

As rochas intrusivas granitoideas na área de estudo formam uma faixa descontínua que estende-se de este a oeste com um rumo paralelo ao eixo da ilha, chamada direção Cuba $\left(120^{\circ}\right)$.

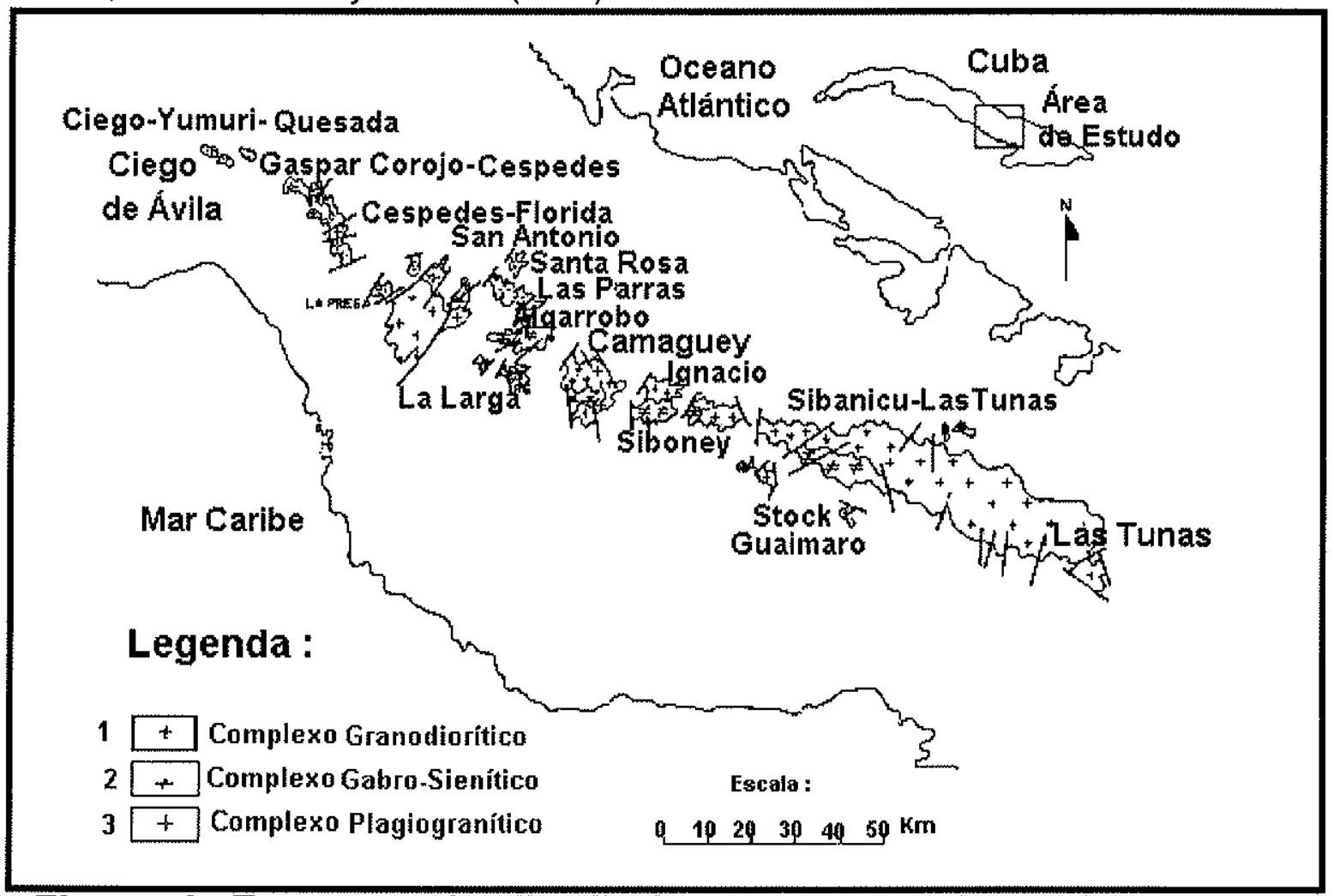

Figura 6. Esquema da distribuição dos complexos intrusivos na área de estudo (Cuba Centro-Oriental).

(Fonte : Iturralde-Vinente. 1994) 
Os granitoides dividiram-se em três complexos bem diferenciados, tanto pelas suas tendências petroquímicas como pelas suas características petroquímicas, mineralógicas, estruturais e a sua localização geológica e geográfica. Estes complexos são: o granodiorítico, o gabrosienítico e o plagiogranítico (Figura 6).

Todos os granitoides estão associados em espaço e tempo a rochas vulcânicas de composição equivalente. Uns e outros representam membros dos mesmos complexos vulcânico-plutônicos em niveis estruturais variáveis, e apresentam uma relação genética estreita, se derivando dos mesmos magmas, só que os granitoides representam uma cristalização mais profunda com uma evolução petrológica mais complexa, proporcionando uma composição química não totalmente igual; nos granitoides, predominam os membros ácidos finais, enquanto nos vulcanitos predominam generalmente os membros intermediários.

$\mathrm{Na}$ área de estudo considera-se que uma última fase do magmatismo é representada fundamentalmente por granitos leucocráticos e granitos feldspáticos alcalinos e, em menores proporções, por lamprófidos e porfiritos dioríticos.

Nas províncias estudadas, paralela ao eixo magmático da ilha, aparece uma grande zona de alteração que se estende por mais de $200 \mathrm{Km}$ entre as formações vulcanogénicas e os granitóides. As principais alterações associadas aos granitóides são as zonas argilíticas, illíticas, de propilitização e de anfibolitização. Outras alterações pós-magmáticas tardias e hidrotermais de caracter local são epidotização, cloritização, carbonatização e zeolitização.

\section{Neoautôctone (Cobertura Cenozoica)}

\subsection{Paleógeno}

\section{Formação Vertientes}

Os sedimentos do Paleogêno jazem sobre as estruturas cretácicas do Arco Vulcânico, Complexo Ofiolítico, Margem Continental e da Plataforma.

A Formação Vertientes desenha uma faixa no terreno nas partes central e sul central da região entre Ciego de Avila e Camaguey. A sua composição é variada; margas, arenitos, radiolaritos, gravelitos, conglomerados, calcários e tufitos. É característica da formação a variação nos conteudos de argila, carbonatos e material terrígeno, o que provoca transições entre uma litologia e outra na vertical, mesmo que na horizontal. Esta coberta transgresivamente pela Formação Guines e Paso Real. A espessura varia entre $30-60 \mathrm{~m}$ em alguns perfis até $430 \mathrm{~m}$ em outros. A idade determinada por associações fossiliferas é Eoceno Inferior alto a Eoceno Médio. 


\subsection{Neogêno}

\section{Formação Guines}

Os depósitos neogênicos de Cuba encontram-se amplamente representados e difundidos, alcançando um magnífico grau de afloramentos em quase todos os casos. Das unidades do Mioceno é a Formação Guines a de maior distribuição no território nacional desde o ocidente do país até Ciego de Ávila, principalmente.

Os depósitos estão representados por calcários detríticos de graõ fino a médio, fossiliferos, biohérmicos, calcários, dolomitos, calcários sacaroidais e, as vezes, lentes de margas calcárias e calcarenitos. Entre outras, jaze transgresivamente sobre a Formação Caobillas. É coberta discordantemente pela Formação Vila Roja, do Quaternário. A idade atribuída é Mioceno Inferior parte alta até Mioceno Médio parte baixa. A espessura oscila entre 60 e $390 \mathrm{~m}$.

\subsection{Quaternário}

\section{Formação Vila Roja}

Os depósitos estão representados pelas seqüências a seguir:

-areias de granulação variada, com cascalhose argilas.

-argila e argilas com intercalações de cascalhose areias.

-formações de pântanos de turfas.

-aluviões de rios e correntes temporais.

-calcários recifais.

A Formação Vila Roja desenvolve-se em forma de manto pouco espesso nas zonas planas das províncias de La Habana, Matanzas, Cienfuegos, Sancti Spíritus, Ciego de Ávila e Camaguey. Esta formada por argilas areno-limosas, areia argilosa e areia quartzosa de variada granulometria, colorida por hidróxido de ferro (goethita). Jaze discordantemente sobre as formações Cantabria, Cojimar, Colón, Crucero, Contramaestre.

A idade é Pleistoceno Médio e a espessura dos seus sedimentos oscila entre 2 e $40 \mathrm{~m}$. A Figura 7 apresenta a distribuição geral dos componentes mais representativos dos elementos estruturais descritos na área de estudo

Na Figura 7 podem diferenciar-se os dois niveis estruturais diferentes citados: a Faixa Dobrada, formada na nomeada Orogênia Norte-Caribenha (Campaniano Médio até Eoceno Médio) e o Neoautôctono (Eoceno Superior Quaternário). A essa faixa são agregados diferentes terrenos formados em diferentes ambientes geotectônicos. Ao norte estendem-se porções da margem continental norte-americana (Plataforma da Bahamas) e no sul são conhecidas amplas exposições de rochas provenientes de um provável continente sulino, cuja idade considera-se também Pré-Mesozoico, mas que 


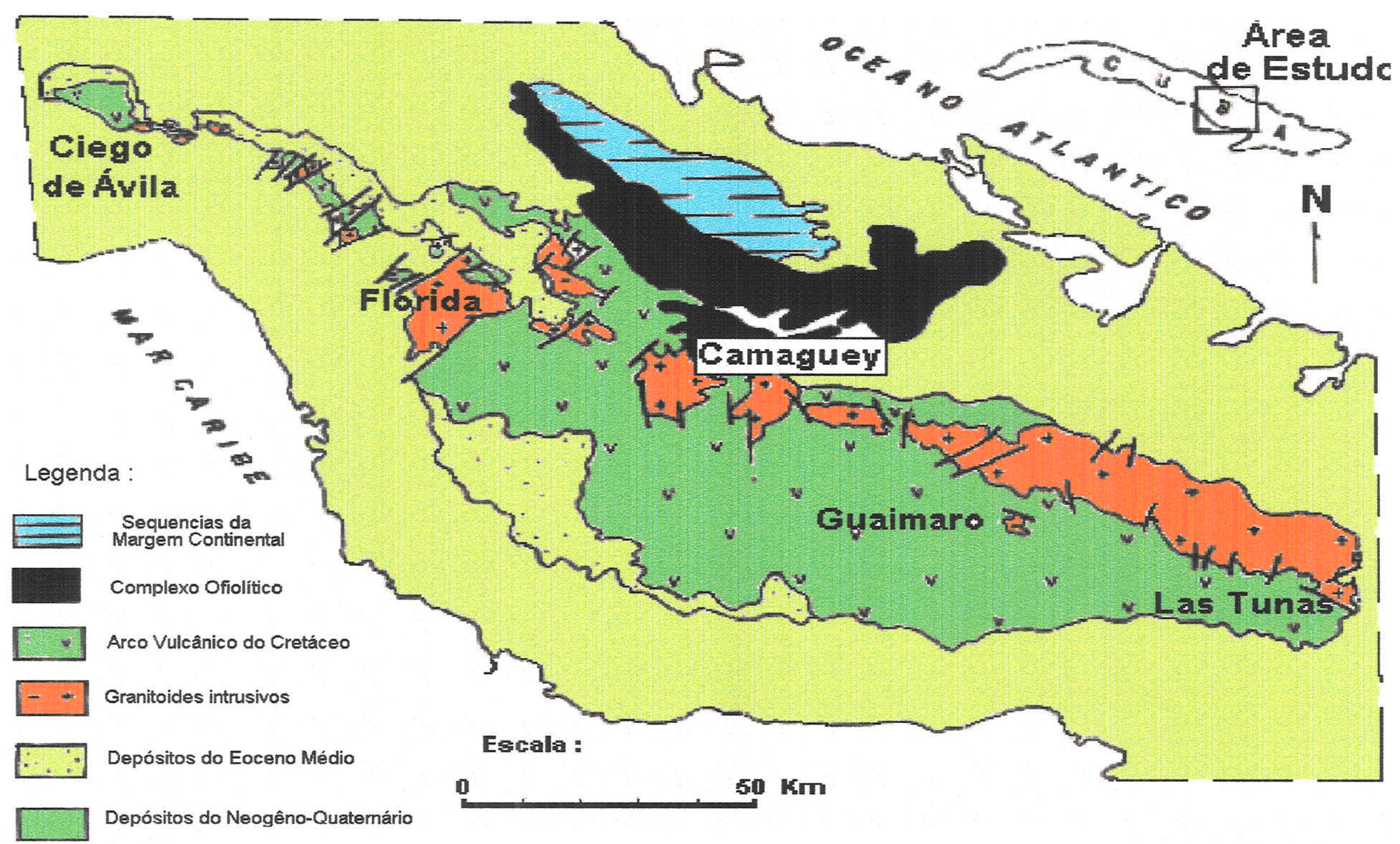

Figura 7 .Mapa geológico da área de estudo, Cuba Centro-Oriental.

(Fonte : Iturralde-Vinent, 1994) 
não estão presentes na área de estudo. O Complexo Ofiolítico do Mesozóico Tardio sobrepõe-se tectonicamente à margem continental norte-americana, e é comumente coberto pelo arco de ilha cretáceo, caracterizado pelas atividades ígneas intrusiva (granitos-granodioritos) e extrusiva (gabros, e tufitos). Bacias superpostas e depressões de avanço (Maestrichtiano-Eoceno Médio) constituem o fim do arco e da ação da Orogenia.

A área de estudo abrange a margem continental Norte-americana (JsupKsup), os ofiolitos do Mesozóico, amplos setores do arco vulcânico de itha Cretácico (Aptiano-Campaniano Médio), as bacias superpostas das depressões de avanço (Maestrichtiano-Eoceno Médio) e a cobertura sedimentar Cenozóica, que, na atualidade, constitui principalmente o calcário carstificado, de ampla difusão na área de estudo e na parte ocidental do país. $\mathrm{Na}$ Figura 8 apresentam-se as manifestações atuais dos processos que deram origem à configuração da região de estudo, assim como a distribuição das diferentes formações geológicas agrupadas pelas idades.

Nesta figura indica-se um sistema de falhas, La Trocha, relacionado com os processos geológicos, para ilustrar a influência e participação que podem exercer no desenvolvimento da hidrogeologia regional. O sistema de falhas e fissuras existentes não é só o apresentado na Figura 9, pois também existem outros sistemas com direções perpendiculares, NE-SO, que não foram representadas no mapa. Algumas hipóteses relacionam diferentes tipos de falhas com a idade da sua gêneses(Capote Marrero,1997), que podem constituir mais um critério de prospeção hidrogeoquímica das águas minerais, podendo destacar alguma diferença entre o quimismo das águas do território e estes diferentes tipos de falhas, devido aos caminhos que as falhas abrem nas profundidades, à circulação das águas subterrâneas.

Neste sentido constatou-se, na zona dos granodioritos de Las Tunas, uma estreita relação entre a emergência das águas subterrâneas cloretadas, num dos sistemas de fisuramento paralelos às falhas regionais.

Demonstrou-se, ao generalizar na superfície dos granodioritos de Las Tunas sobre os distintos tipos de águas existentes, que estes distribuiam-se com determinada regularidade, sendo os tipos cloretados com STD> $1000 \mathrm{mg} / \mathrm{L}$, os que conformavam-se melhor alinhados. Os tipo hidrocarbonatados distribuiam-se de forma mais irregular, contornando os cloretados e, os sulfatados, distribuídos entre ambos. Comparou-se os alinhamentos do tipo cloretado com os alinhamentos dos sistemas de falhas no território e deram correspondência com os sistemas existentes de direção NE-SO, da Falha Regional Camaguey (Valdés González e Kimmelmann e Silva, 1998).

Da análise da distribuição das formações geológicas existentes na região de Cuba Centro-Oriental constatou-se que as sub-regiões Camaguey e Las Tunas compreendem as mais representativas da faixa mais antiga dos complexos citados. A província de Ciego de Ávila possui uma ampla distribuição das formações mais recentes, a cobertura cenozóica, representadas pelas rochas carbonatadas do Neogeno que interrompem em 


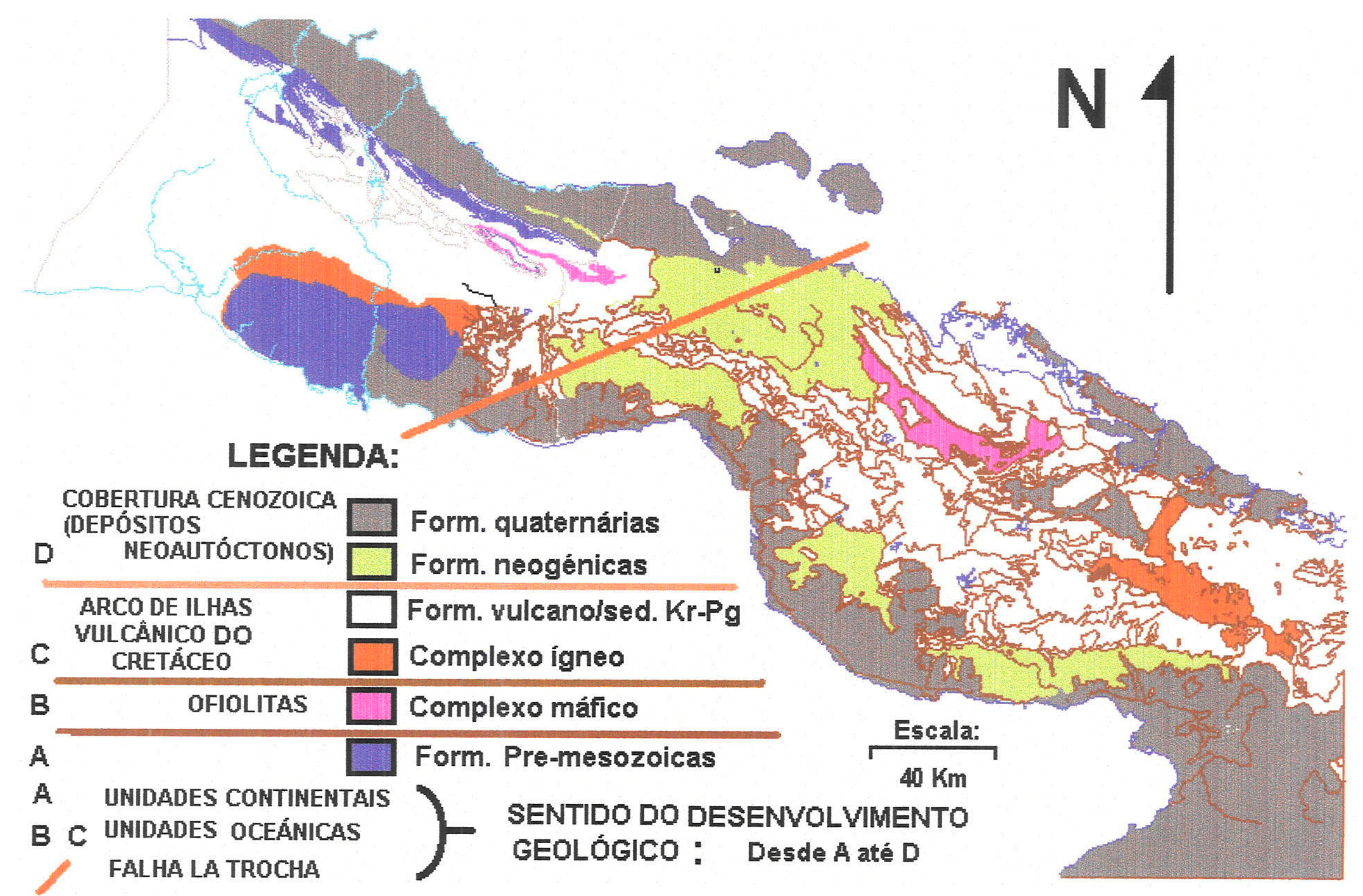

Figura 8. Apresentação dos grupos estruturais segundo a distribuição das idades dos conjuntos das formações geológicas.

(Fonte : Capote Marrero, 1998) 

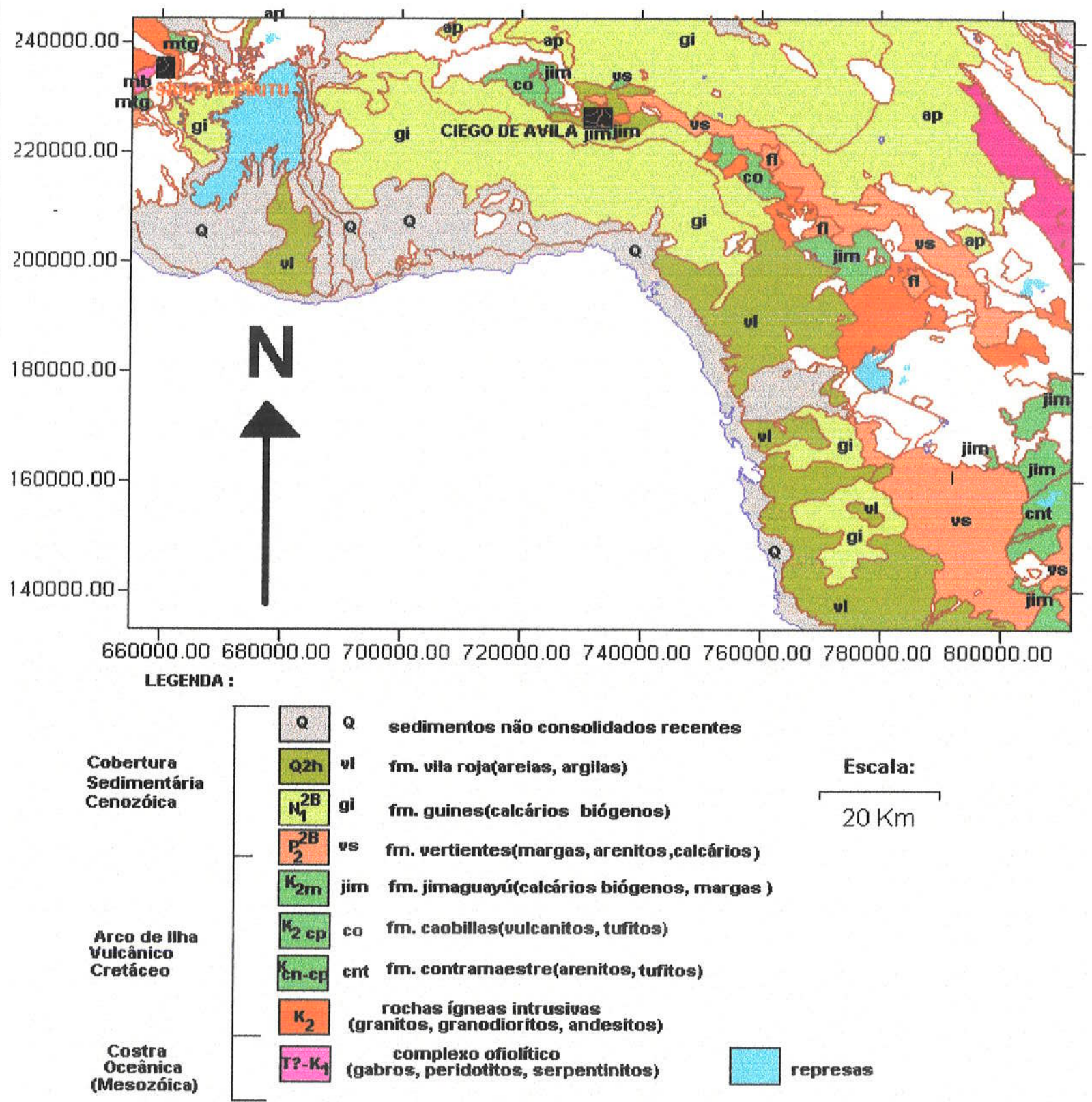

NOTA: Coordenadas Lambert, Cuba Norte

Figura 9. Mapa Geológico da Província Ciego de Ávila. (Fonte : Mapa Geológico de Cuba, 1988.) 


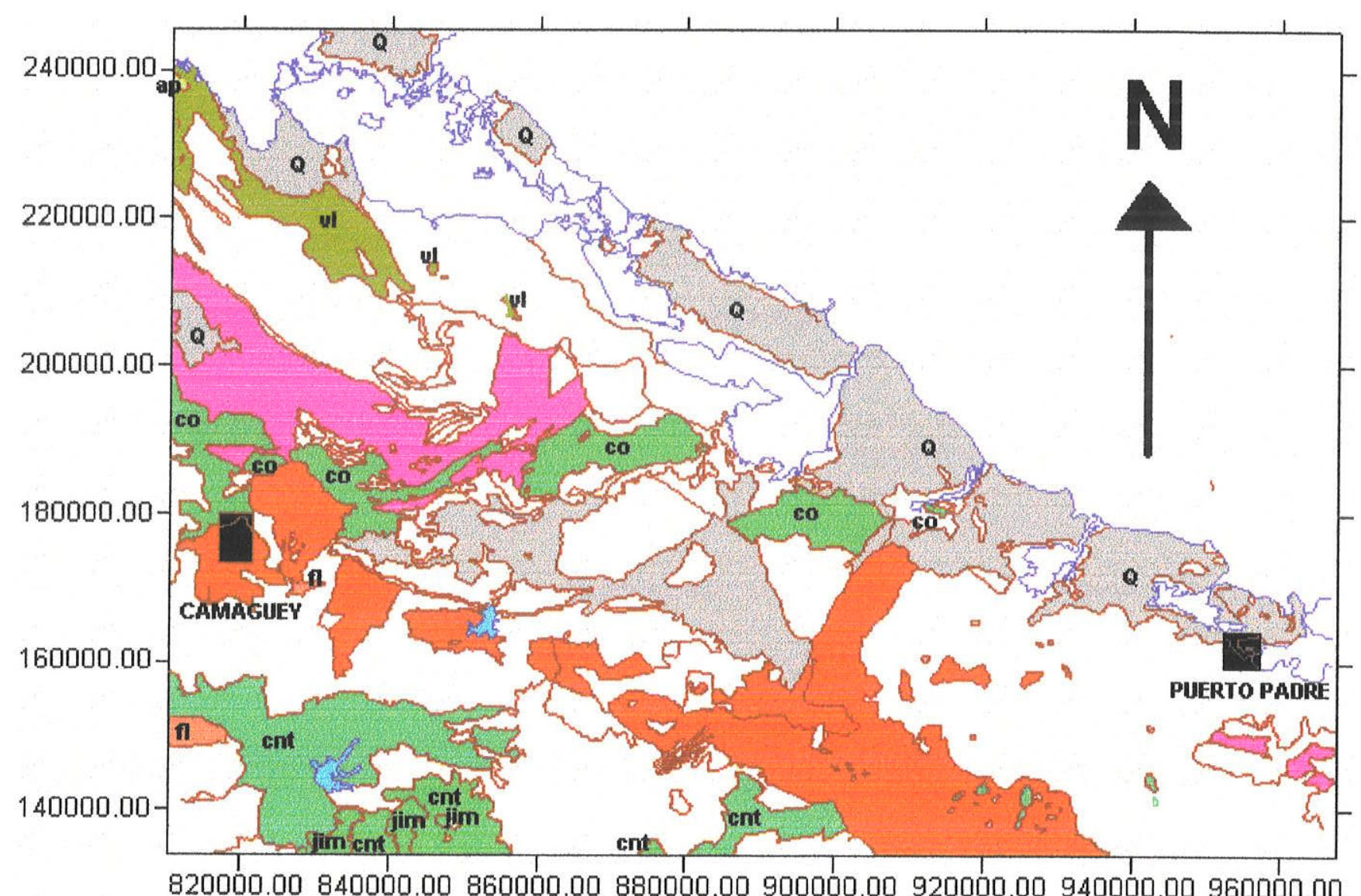

LEGENDA :

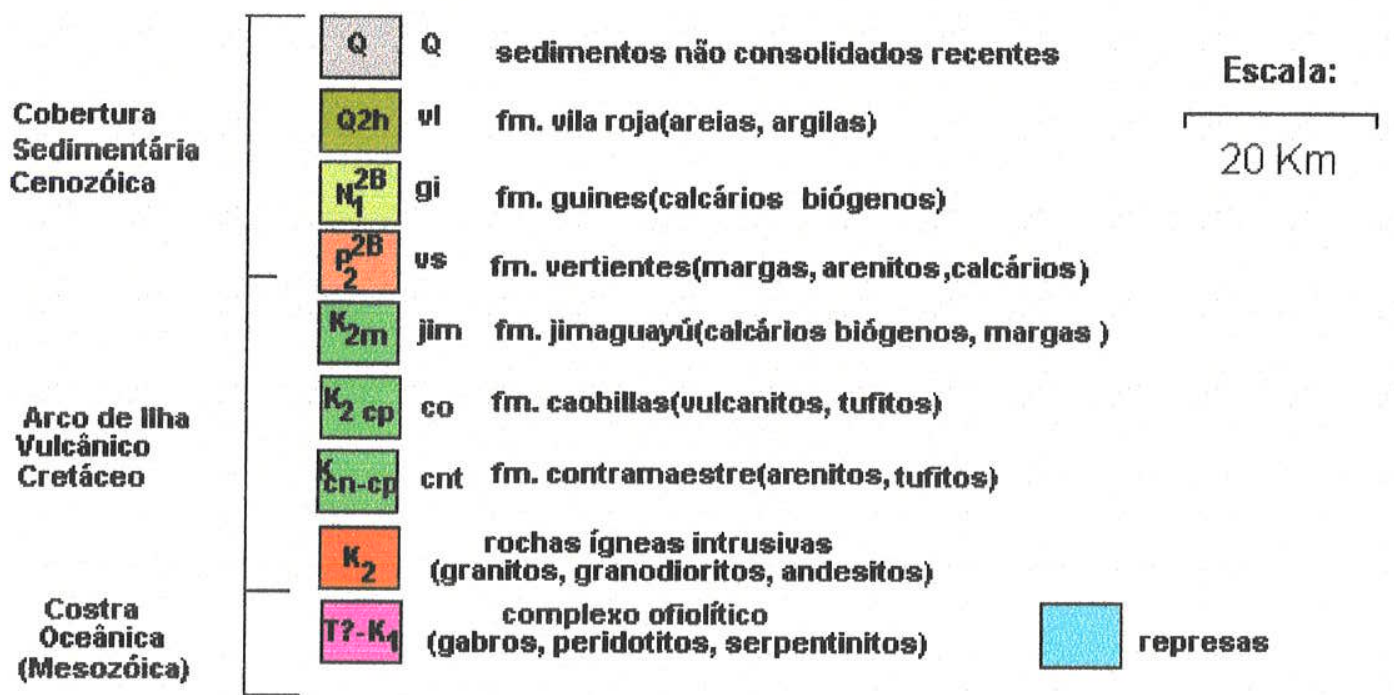

NOTA: Coordenadas Lambert, Cuba Morte

Figura 10. Mapa Geológico da Província Camaguey. (Fonte : Mapa Geológico de Cuba, 1988.) 


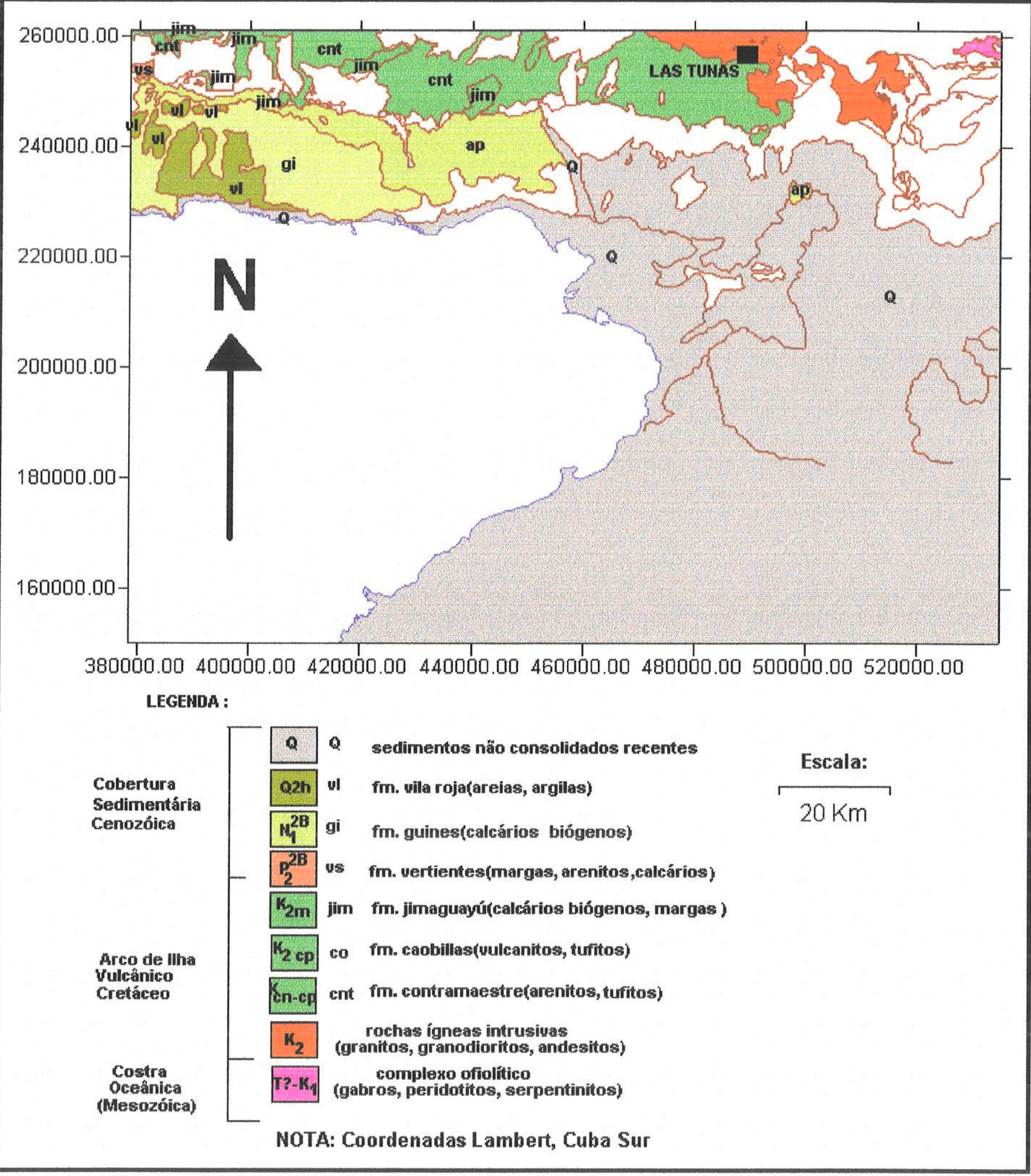

Figura 11. Mapa Geológico da Província Las Tunas. (Fonte : Mapa Geológico de Cuba, 1988.) 
superfície as continuidades territoriais destas formações geológicas mais velhas até Cuba Central. Estas continuidades são desplazadas entre si pela Falha La Trocha (Figuras 9, 10 e 11).

No caso de Camaguey, esta possui uma boa área exposta do complexo ofiolítico, considerado na Geologia Cubana o mais antigo, Triássico TardíoCretácico inferior (Iturralde Vinent et al, 1994) .

O aspecto relevante das referidas distribuições destas formações geológicas na região de estudo é a possibilidade de assumir o território como um sistema particular do resto do pais para os fins de análise hidrogeológica das águas minerais. Daí que as interpretações tem também a finalidade de argumentar até onde e sob que condicionantes pode se considerar este sistema fechado ou aberto.

\subsubsection{Aspectos tectônicos}

A história geológica refletida nas estruturas existente é mostrada na Figura 12. Nela pode ser apreciada uma área elevada composta pelas formações mais velhas até as compreendidas pelo Arco Vulcânico. As formações geológicas mais jovens, do Neogeno até o Recente, a Cobertura Cenozóica, conformam uma área circundante de menor elevação.

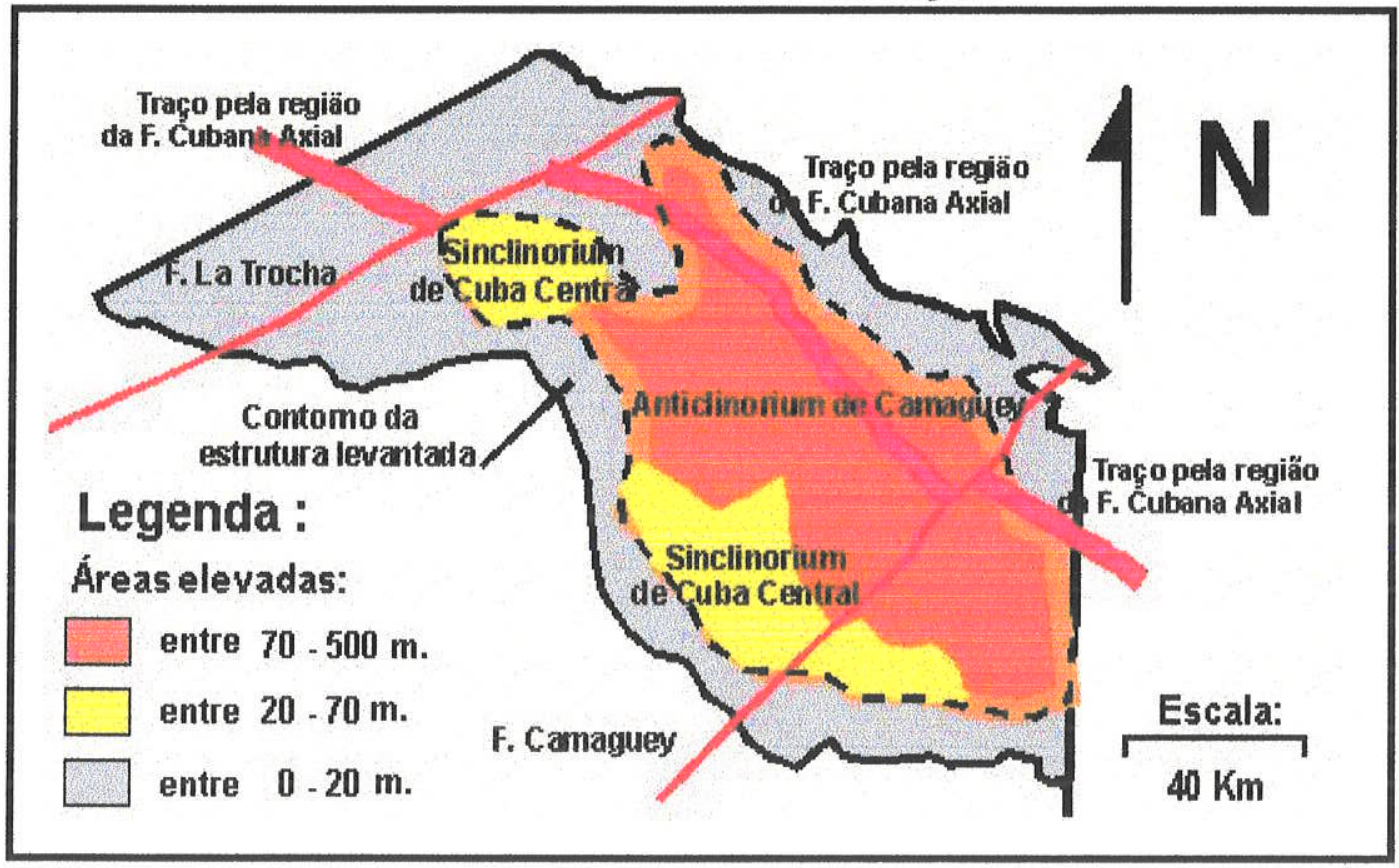

Figura 12. Esquema das principais configurações tectônicas da área de estudo.

(Fonte : Adaptado de Iturralde-Vinente, 1994.)

Deve se notar ainda que a área elevada alonga-se na direção da Falha Cubana Axial (NO-SE), constituindo as suas bordas elevadas, direções quase paralelas à mencionada direção. Estes alinhamentos são interrompidos transversalmente, na direção NE-SO, pelos sistemas das falhas La Trocha e Camaguey. 
Outra consideração é a extensão e situação da área que constitui o anticlinorium de Camaguey, rodeado ao sul pelas áreas do sinclinorium de Cuba Central. Estas apreciações serão úteis quando da análise dos fatores da entrada, circulação e saída, das águas minerais.

\subsubsection{Recursos minerais}

A concentração dos minerais útil é reflexa da história geológica do território estudado. A Figura 13 apresenta em base geológica, as atuais jazidas em exploração. Existe petróleo no extremo centro-ocidental, província de Ciego de Ávila, relacionado aparentemente com os lineamentos tectônicos. Gesso e sal gema relacionam-se com os domos salinos, ao extremo norte-ocidental desta província.

Os minerais metálicos relacionam-se com as manifestações ígneas e os seus contatos com o complexo ofiolítico e o Arco Vulcânico das províncias de Camaguey e Las Tunas, e os não metálicos, calcários, magnesitos e argilas, com os sedimentos do Neogeno-Recente das três províncias.

Preliminarmente pode-se supor que estes sejam os grandes condicionantes que favorecem os extremos centro e norte-ocidental de Ciego de Ávila a possível apresentação de águas sulfurosas e cloretadas-sulfatadas, de mediana a alta mineralização, respectivamente.

É possível esperar também águas predominantemente bicarbonatadas de baixa mineralização, particularmente com sílica e componentes ferruginosos, ou outro metal específico, naquelas áreas das formações ígneas, ofiolitos e os seus contatos.

Nas áreas do Neogeno, menos elevadas, constituídas por calcários com diferentes graus de alteração, pode se estimar a presença de águas bicarbonatadas cálcicas principalmente. Estas águas devem ser estimadas de apresentar mediana a baixa mineralização devido a receberem todo 0 escoamento das áreas mais elevadas. Deve-se considerar sempre a possivel variação deste quimismo a cloretadas sódicas nas áreas costeiras, pela influença da intrusão marinha.

As considerações assumidas, a partir das manifestações minerais, conjuntamente com as formações e estruturas geológicas, permitem estabelecer um patamar hidrogeoquímico qualitativo, no qual destacam-se os quimismos anômalos e as suas procedências.

Deve se destacar que o mapa base das jazidas não tem indicadas águas minerais devido as suas jazidas predominaram na metade ocidental do país. Apenas uma jazida na parte centro-oriental, Camujiro, foi explorada, e, como na época da confecção do mapa, esta fonte estava já abandonada (Lavandero et al, 1987), não foi considerada. 


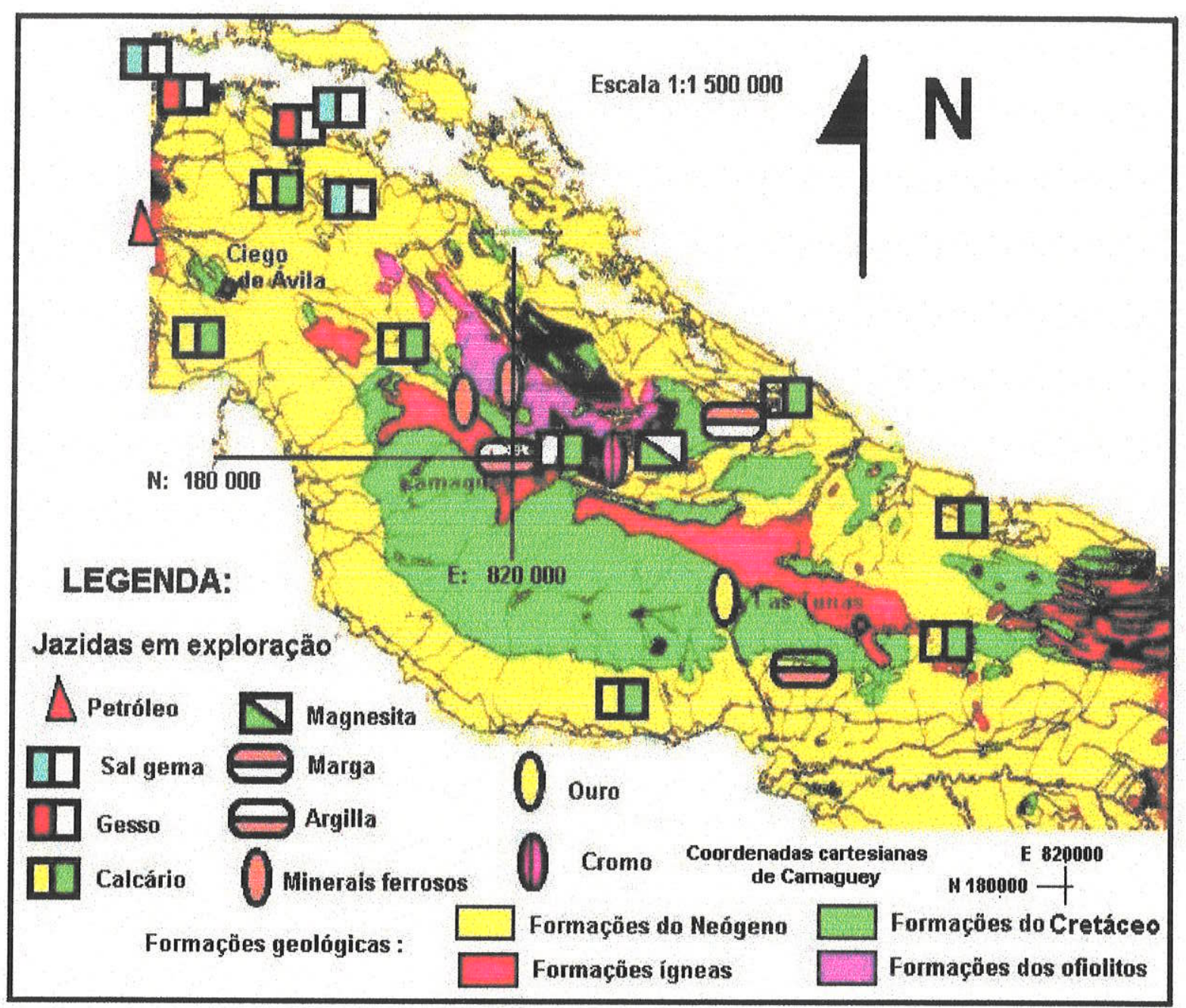

Figura 13. Mapa dos tipos de jazidas existentes na Área de Estudo. (Fonte : Núñez Jiménez et al, 1970.)

\subsubsection{Geomorfologia}

As elevações estruturais indicadas nos aspectos tectônicos são apresentadas no mapa do relevo da Figura 14. Observa-se que as áreas relacionadas com os ofiolitos e com o Arco Vulcânico têm altitudes entre 50 e 200 metros acima do nível médio do mar. As áreas pertencentes à Cobertura Cenozóica são mais baixas que $50 \mathrm{~m}$.

A distribuição do relevo sugere que a Cobertura Cenozóica, com altitudes abaixo dos $50 \mathrm{~m}$, possa funcionar como o principal receptor das águas que circulam acima e abaixo dos ofiolitos e do Arco Vulcânico, mais antigos, o que leva à pergunta sobre o que podia acontecer se, a profundidade máxima do nível dinâmico de exploração das águas minerais fosse superior a 50 nasregiões mais elevadas, especialmente se a surgência aflorasse nos calcários do Neogeno. 
LEGENDA :

Altitudes :

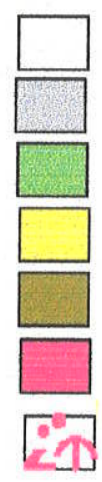

Nivel do mar

$0-20 \mathrm{~m}$.

$20-40 \mathrm{~m}$.

$40-70 \mathrm{~m}$.

$70-120 \mathrm{~m}$.

Relevo de alturas residuais e montanhas pequenas

$<500 \mathrm{~m}$.

Diferentes tipos de manifestacōes de carste Escala 1:1500 000

Figura 14. Mapa das áreas elevadas na região de estudo.

(Fonte : Adaptado de Nuñez Jimenez et al, 1970.)

\subsubsection{Manifestações de carste}

A Figura 15 apresenta a distribuição das manifestações cársticas na área de estudo. A área de rochas não carbonatadas corresponde ao Complexo Ofiolítico (considerado entre as formações mais antigas da história geológica cubana), e às formações do Complexo Plutônico e Metamórfico.

Observa-se que somente o centro do anticlínio, na parte mais elevada não possui manifestações cársticas.

Nota-se que as demais formações pre-neogénicas têm componentes carbonatados que condicionam as diferentes manifestações cársticas até os calcários do Neogeno onde se manifesta o carste clássico. Particular atenção deve ter-se nas áreas ao norte, em contato com o complexo ofiolítico, que pertencem à Margem Continental Norte-Americana (Figura 3), constituída por sedimentos carbonatados e não carbonatados com idade de Cretáceo Inferior, que condicionam fenômenos cársticos de alto grau de desenvolvimento, segundo o predomínio dos calcários na formação. 


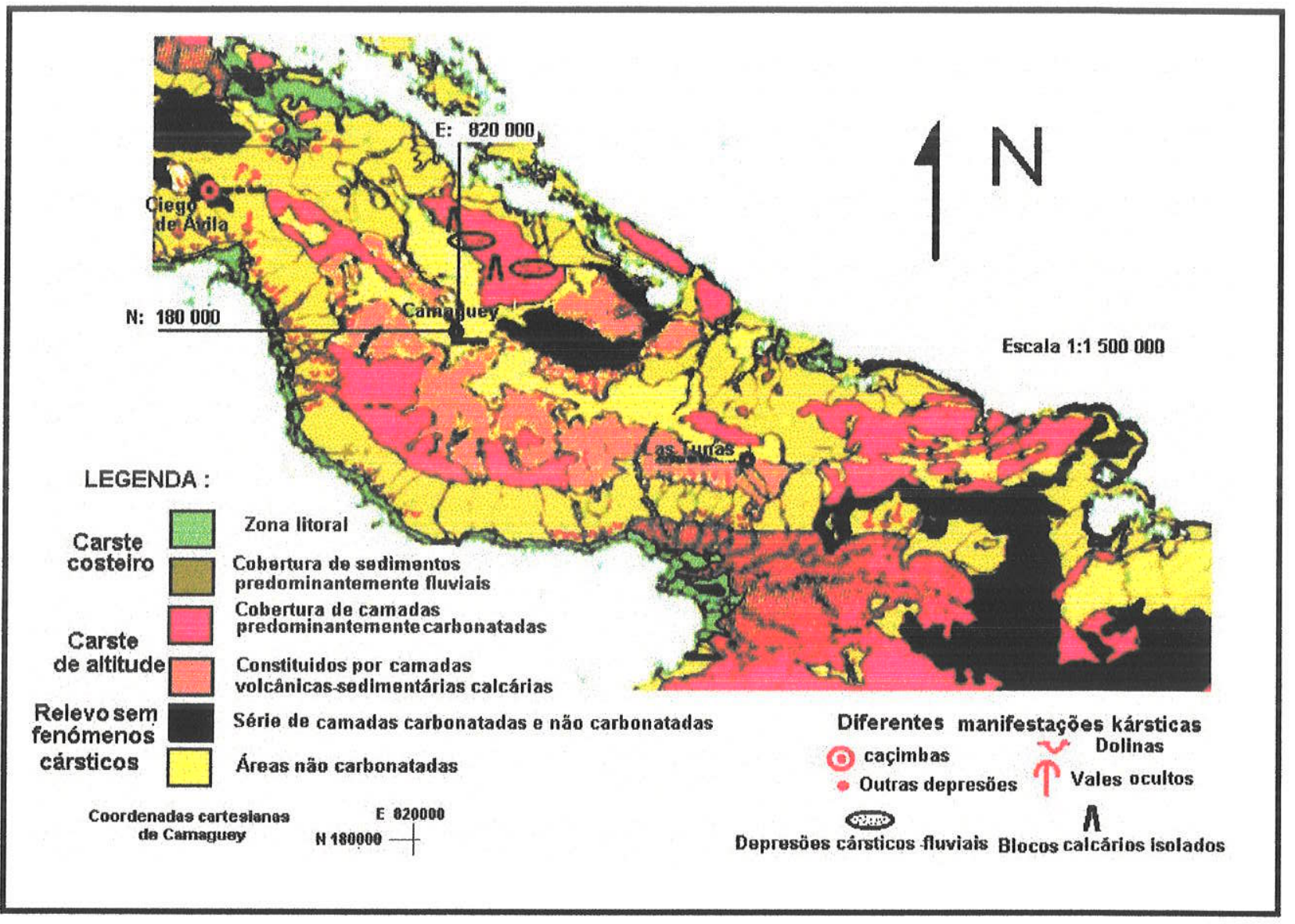

\section{Figura 15. Mapas das diferentes manifestações cársticas na área de estudo.}

\section{(Fonte : Nuñez Jimenez et al, 1970.)}

Do ponto de vista das procuradas condicionalidade hidrogeológica, para a sua aplicação ao sistema hidrogeológico das águas minerais, este carstismo pode criar nessa parte do território, a mínima infiltração da água na zona central, com exceções nos terrenos altamente castificados da margem continental, onde a vazão de recarga pode ser localmente elevada.

A recarga mais elevada será nas partes mais baixas dos calcários que constituem a Cobertura Cenozóica, mas que pouco contribuirá às futuras vazões de águas minerais como água de infiltração. A área intermédia na estrutura elevada permite supor vazões de infiltração de moderada a alta, segundo a localidade específica, mas que si permitirão contribuir à alimentação das águas minerais.

Isso permite deduzir, em sentido geral, que as possibilidades de vazões de recarga notáveis de águas minerais ficam mais para os limites entre a Cobertura Cenozóica e o Arco Vulcânico que para os ofiolitos, onde, se aparecem vazões desta natureza, devem estar relacionadas com circulação profunda ou mais superficial, ligados a entradas locais. Desde outro ponto de vista, esta zona intermédia resulta mais perspectiva pela possibilidade também que as suas vazões sejam mais estáveis e, por enquanto, supor os processos de recarga e quimismo mais constante. 


\subsubsection{Precipitações}

As precipitações constituem fator primário da alimentação das águas subterrâneas e, por isso, das águas minerais. A Figura 16 mostra a distribuição média anual de precipitações, tanto em Cuba como da área de estudo. Devido a sua posição entre os Trópicos e sem elevações maiores que $2000 \mathrm{~m}$, não existem precipitações nem acumulações de neves. O valor meio anual é de $1300 \mathrm{~mm}$. Pode se apreciar na figura os valores médios anuais das províncias: Ciego de Ávila $(1264 \mathrm{~mm})$, Camaguey $(1326 \mathrm{~mm})$ e Las Tunas (1126 mm).

Relacionando estes fatos com o mapa tectônico da Figura 13, pode-se estabelecer uma possibilidade de circulação subterrânea intensa em direção NO-SE, se não for interceptada pelos sistemas principais de falhas NE-SO, influindo nas suas permeabilidades.

Considerando o valor médio das precipitações que recebe a região (1300 $\mathrm{mm} / \mathrm{ano}$ ) pode se estimar uma recarga suficiente para as vazões resultantes das águas subterrâneas.

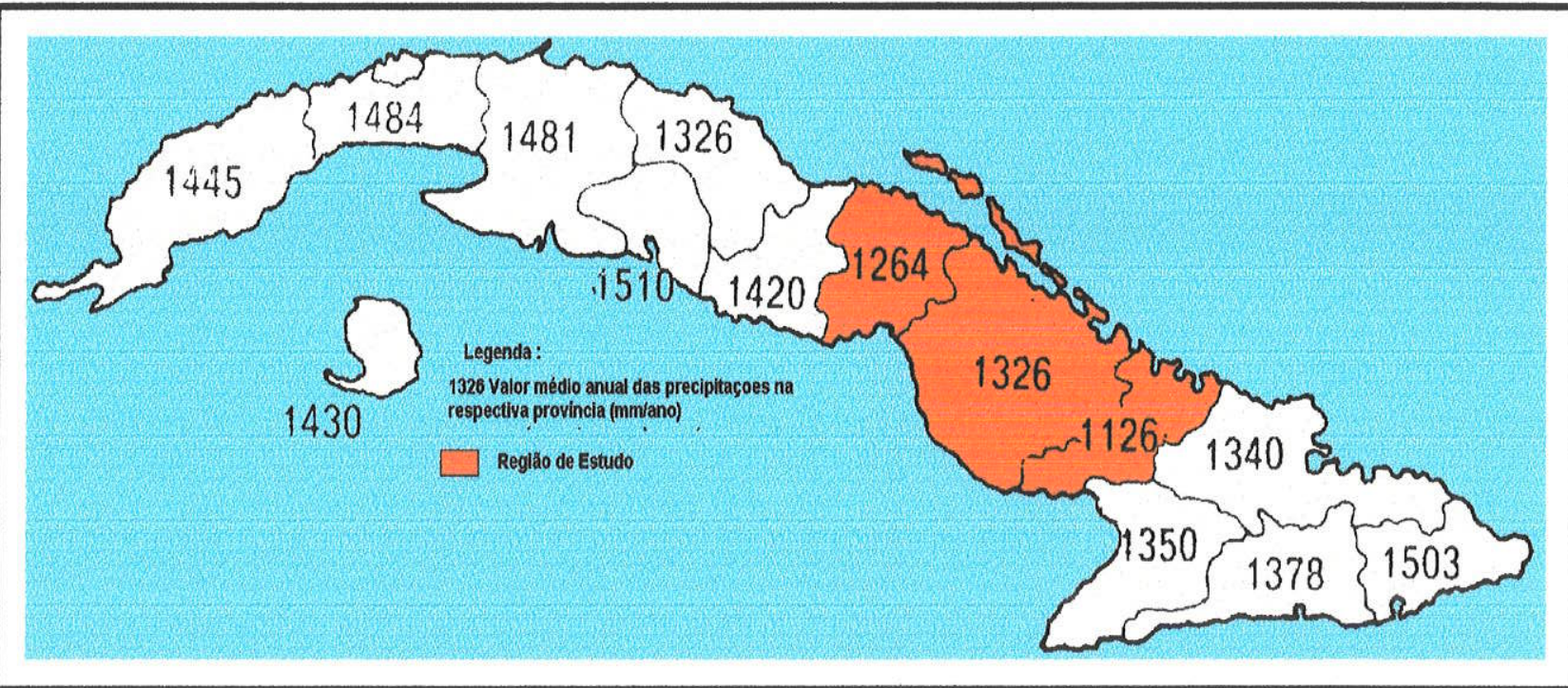

\section{Figura 16. Distribuição das precipitações médias anuais em Cuba com enfâse para a Área de Estudo.}

(Fonte : Adaptado de Núñez Jiménez et al,, 1970.)

\subsubsection{Escoamento superficial}

O escoamento superficial é o resultado da ação das águas das precipitações no relevo superficial, mantidas até que alcançarem o nível de base mínimo, seja o mar ou outra grande receptora de águas. O escoamento superficial, agindo nas rochas sobre as quais escoa, torna-se um dos agentes de erosão mais enérgicos da Natureza e os seus rastros no relevo permitem compreender e tirar considerações sobre o que acontece abaixo da superfície. 
A maioria dos rios de Cuba não tem grandes vazões e os seus níveis da águas dependem muito das estações climáticas, chegando os níveis mais baixos durante o período de estiagem. Existem muitos cursos curtos que são ativos apenas durante o período de precipitações. $\mathrm{O}$ escoamento médio anual de todos os rios de Cuba é estimado em $30 \mathrm{~km}^{3}$.

A Figura 17 apresenta a distribuição dos rios na área de estudo. Nela pode se ver que a divisória principal é estabelecida na área elevada estruturalmente e através das rochas não carbonatadas (ofiolitos e granodioritos) até chegar à zona da Cobertura Cenozóica.

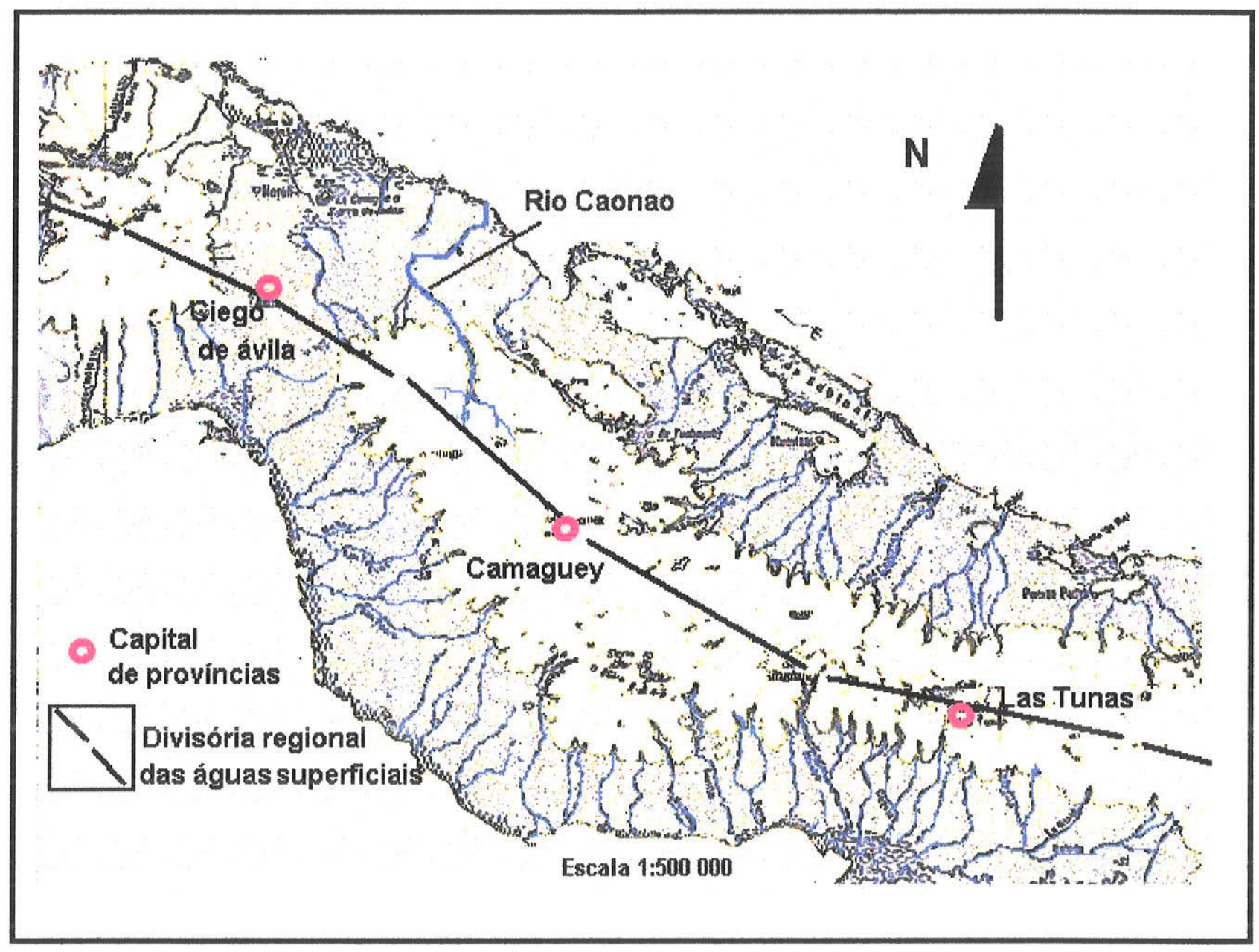

Figura 17. Distribuição dos rios existentes na área de estudo. (Fonte: Nuñez Jimenez, 1970)

Todos os rios descem à costa diretamente a partir desta divisória central, a exceção do rio Caonao. Este rio é o maior das províncias centro-orientais, com $133 \mathrm{~km}$ de comprimento e desce com um curso torto que pode representar as irregularidades particulares da geologia e da drenagem subterrânea, o qual aparece destacado no mapa da Figura 17. 
O escoamento médio anual dos rios na região de estudo está entre um mínimo de $6.10^{6} \mathrm{~m}^{3}$ e um máximo de $1270.10^{6} \mathrm{~m}^{3}$. Estas vazões têm sido aproveitadas com o fim do uso na agricultura principalmente, através de barragens nos seus leitos. A Tabela 4 apresenta os valores para cada uma delas e as figuras 18,19 e 20 apresentam as respectivas distribuições das barragens nas suas províncias.

Do ponto de vista do balanço hídrico, a informação conseguida calcula valores anuais de $2162.10^{6} \mathrm{~m}^{3}$ para as águas superficiais e de $1230.10^{6} \mathrm{~m}^{3}$ para as águas subterrâneas (ATANASOV et al, 1969).

Deve se considerar que os valores são de água explotada no momento e não da existência total nas províncias.

\subsubsection{Hidrogeologia}

Do ponto de vista hidrogeológico, as informações generalizadoras são escassas, mantendo-se o Mapa Hidrogeológico de Cuba 1:1 000000 (Lueges et al, 1977) ainda vigente. Devido a que as formações cársticas, as mais aqüíferas de Cuba, constituem o alvo básico das pesquisas e explorações das águas subterrâneas, as informações mais completas e generalizadoras estão nas formações dos calcários, principalmente do Neógeno. A Figura 21 apresenta a parte do mencionado mapa correspondente à área de estudo, destacando os elementos mais relevantes.

As descrições das aquosidades das formações geológicas também não são muito detalhadas no seu sentido geral, excetuando as formações cársticas(Fagundo et al, 1998) e localidades de algum interesse de exploração, devido à presencia de água subterrânea por fraturas e agretamentos.

Neste sentido, as descrições mais generalizadas estão agrupadas estratigráficamente pelos componentes litológicos mais representativos das formações pertencentes à evolução geológica já descrita.

\subsubsection{Descrições das capacidades aqüíferas dos depósitos estratrigráficos}

As seguintes descrições das caracteristicas hidrogeológicas são de Guzmán et al, 1982.

\section{Rochas Ultrabásicas}

Estão distribuídas em todas as províncias e representadas pelos peridotitos. $\mathrm{Na}$ parte superior do perfil estas rochas têm-se transformado em serpentinitos, manifestando-se nas elevações anticlinais. Observam-se nelas agretamentos em direções variáveis. 


\section{TABELA 4. DADOS TÉCNICOS DAS BARRAGENS CONSTRUÍDAS NA REGIÃO DE ESTUDO. (VIDE DISTRIBUIÇÃO NO TERRITÓRIO NAS RESPECTIVAS FIGURAS)}

\begin{tabular}{|c|c|c|c|c|c|c|}
\hline Província & $\begin{array}{l}\text { Nome da } \\
\text { Barragem }\end{array}$ & $\begin{array}{c}\text { Capacidade } \\
\text { Útil } \\
\left(10^{6} \mathrm{~m}^{3}\right)\end{array}$ & $\begin{array}{l}\text { Objetivo da } \\
\text { Exploração }\end{array}$ & $\begin{array}{l}\text { Nome do } \\
\text { rio }\end{array}$ & $\begin{array}{c}\text { Area da } \\
\text { bacia } \\
\left(\mathrm{km}^{2}\right)\end{array}$ & $\begin{array}{l}\text { Escoamento } \\
\text { médio anual } \\
\left(10^{6} \mathrm{~m}^{3}\right)\end{array}$ \\
\hline $\begin{array}{l}\text { Ciego de } \\
\text { Avila }\end{array}$ & Chambas I & 31 & $\begin{array}{l}\text { Abastecimen } \\
\text { to para } \\
\text { irrigação }\end{array}$ & Chambas & 40 & 15 \\
\hline “ & Chambas II & 33 & & Chambas & 128 & 69 \\
\hline Camaguey & Porvenir & 169 & $"$ & Caonao & 656 & 216 \\
\hline “ & Máximo & 69 & $"$ & Duran & 243 & 90 \\
\hline " & $\begin{array}{l}\text { Amistad } \\
\text { Cubano- } \\
\text { Búlgara }\end{array}$ & 135 & $\begin{array}{c}\text { Abastecimen } \\
\text { to para } \\
\text { consumo }\end{array}$ & $\begin{array}{c}\text { Saramagua } \\
\text { can }\end{array}$ & 280 & 95 \\
\hline " & Muñoz & 114 & $\begin{array}{l}\text { Abastecimen } \\
\text { to para } \\
\text { irrigação }\end{array}$ & Muñoz & 342 & 104 \\
\hline " & Jimaguayú & 197 & & San Pedro & 592 & 164 \\
\hline$"$ & Najasa I & 72 & " & Najasa & 267 & 88 \\
\hline " & Najasa II & 86 & " & Najasa & 808 & 250 \\
\hline Las Tunas & Juan Saez & 102 & " & Chaparra & 41 & 90 \\
\hline $\begin{array}{l}\text { Totais da } \\
\text { região }\end{array}$ & - & 1006 & - & - & 3397 & 1183 \\
\hline
\end{tabular}

(Fonte: Arquivos do Inst. de Recursos Hidráulicos, 1999) 


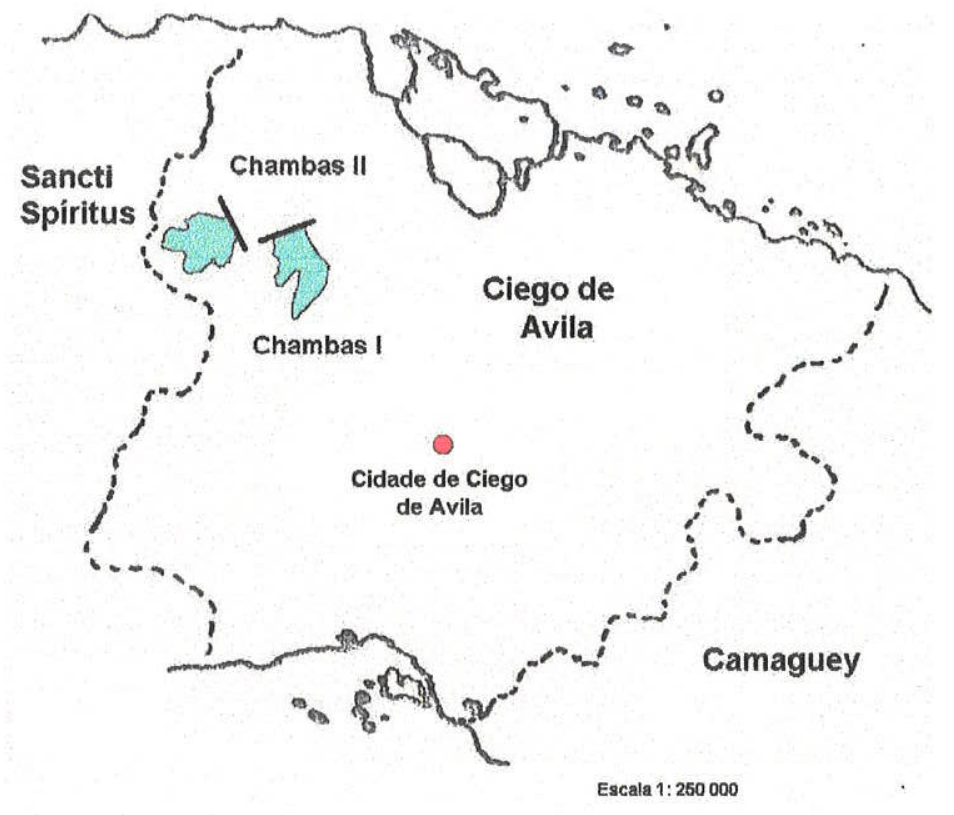

Figura 18. Barragens construídas na província de Ciego de Avila. Dados em Tabela 4 .

(Fonte : Arquivos do Inst. Nac. Recursos Hidráulicos, 1999)

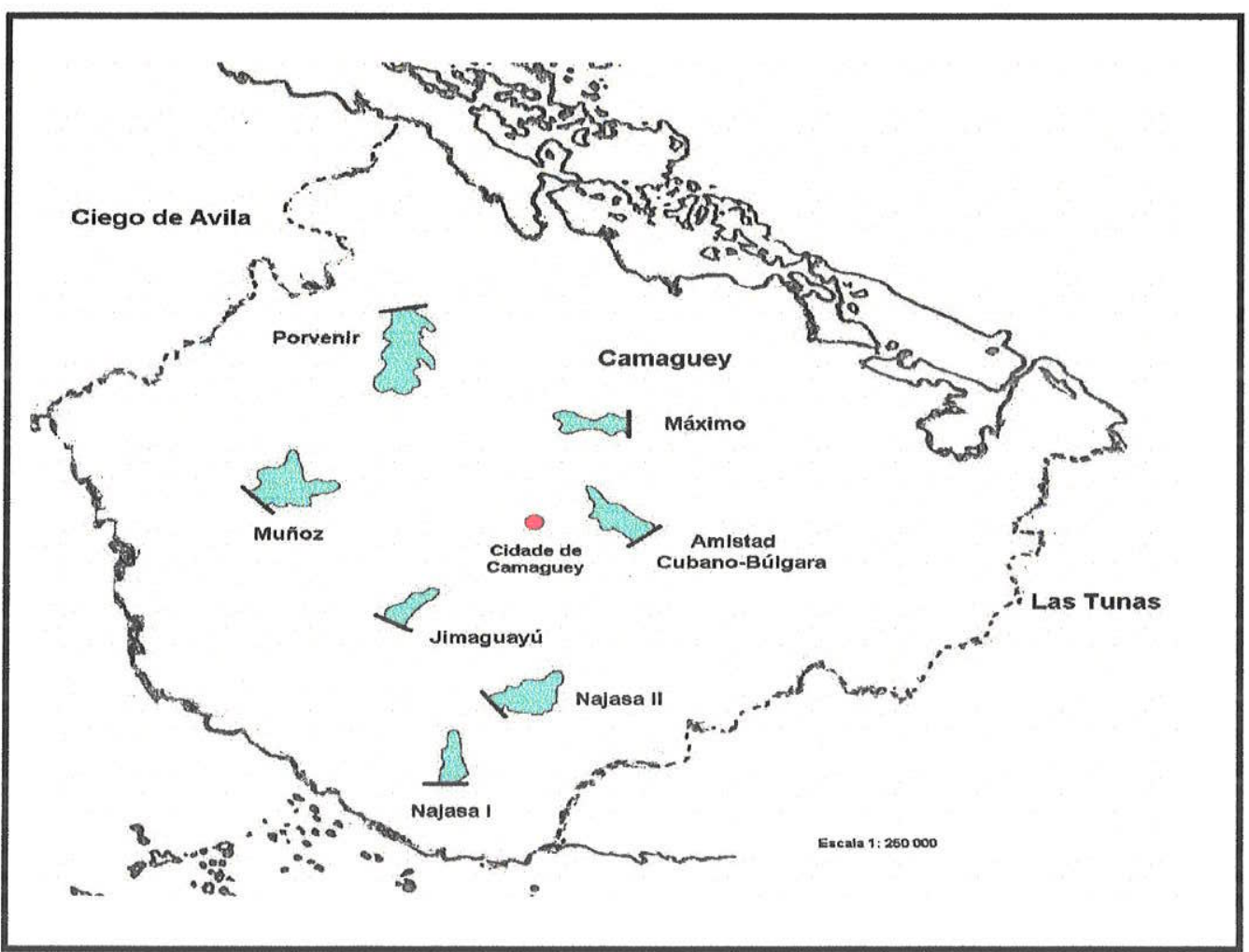

Figura 19. Barragens construídas na província de Camaguey. Dados em Tabela 4

(Fonte : Arquivos do Inst. Nac. Recursos Hidráulicos, 1999) 


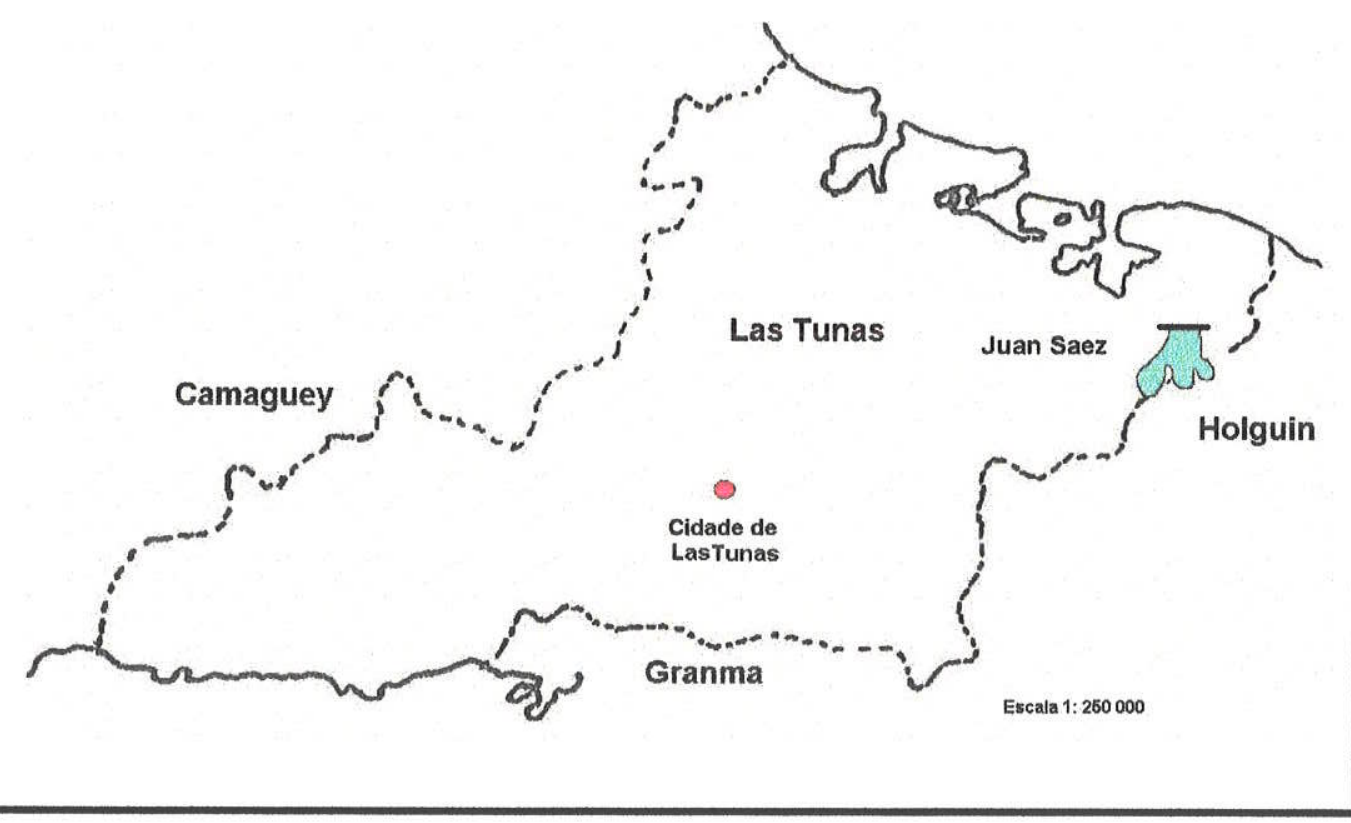

Figura 20. Barragens construídas na província de Las Tunas. Dados em Tabela 4.

(Fonte : Arquivos do Inst. Nac. Recursos Hidráulicos, 1999)

Estas são pequenas em geral e recheias de mineral serpentina. Às vezes, quando maiores, estão relacionados com atividade tectônica. Por isso, as águas estão associadas ao tipo de águas de fissuras.

Nas províncias de La Habana e Matanzas (ao ocidente da área de estudo), registram-se mananciais de águas doces e salinizadas com vazões até $1 \mathrm{~L} / \mathrm{s}$. $\mathrm{Na}$ jazida de cromito de Camaguey, tem-se avaliado a maior saturação de água entre os 30 e $50 \mathrm{~m}$. de profundidade, com vazões entre 0,2 e $0,3 \mathrm{~L} / \mathrm{s}$. Nas zonas de deslocamentos tectônicos, como por exemplo, a $10 \mathrm{Km}$ ao Este da cidade de Camaguey, existem perfurações com vazões de até $20 \mathrm{~L} / \mathrm{s}$.

\section{Granitóides e gabros}

Constituem uma faixa de intrusões, alongadas em forma de cadeias entre as elevações de Guamuhaya, na província de Cienfuegos, ao oeste da área de estudo, e a cidade de Las Tunas. A rocha representativa mais comum é o granodiorito. O gabro ocupa uma extensão relativamente limitada e a sua capacidade aqüífera não esta estudada.

As águas subterrâneas nos granitóides estão associadas a fendas de intemperismo e deslocamentos tectônicos, com vazões menores de $1 \mathrm{~L} / \mathrm{s}$ até alguns L/s, respectivamente. As salinidades destas águas estão entre 1000$3000 \mathrm{mg} / \mathrm{L}$ de STD para o primeiro caso e até menos de $1000 \mathrm{mg} / \mathrm{L}$ de STD para o segundo caso. Consideram-se águas de fissuras. 


\section{Jurássico Inferior e Médio}

Estão amplamente distribuídos na parte ocidental do país, representados nos maciços de Pinar del Rio, llha da Juventude e Guamuhaya. A posição estratigráfica mais baixa corresponde aos mármores e acima deles, os xistos (quarzíticos, micáceos, grafíticos carbonatados e argilosos).

As águas subterrâneas estão associadas a fendas de distintas origens (intemperismo, litogénica e tectônica). As capacidades aqüíferas destes depósitos têm sido pouco estudadas. A vazão nestes grupos é de frações de litros por segundo.

Quando estudados, estes materiais apresentavam vazões de até 1-5 L/s nos xistos quartzíferos em zonas entre a cobertura argilosa e a rocha dura, e superior a $20 \mathrm{~L} / \mathrm{s}$ nos mármores (Valdés González, 1976). São águas de fissuras.

\section{Jurássico Superior}

Estes depósitos estão muito desenvolvidos na provincia de Pinar del Rio e ao Norte das províncias de Villa Clara, Sancti Spíritu e Camaguey. Estão representados por calcários de cor cinza claro, compactos, com intercalações de rochas silícicas. $\mathrm{Na}$ parte superior existem intercalações de calcários arenosos. Esta composição litológica condiciona a presencia dos fenômenos cársticos. Os processos cársticos desenvolveram-se principalmente na direção dos deslocamentos tectônicos. Suas capacidades aqüiferas têm sido pouco estudadas, mas as vazões altas ou baixas dependem do acerto ou não das perfurações nas zonas carstificadas. Consideram-se águas cársticas de fissuras.

\section{Cretáceo}

Estes componentes existem distribuídos em todo o território nacional, representado pelas rochas carbonatadas, terrígenas e vulcânicas. Os carbonatos estão representados pelos calcários e menos freqüentemente pelos dolomitos e margas. Com muita freqüência encontram-se ao Norte das províncias Ciego de Ávila e Camaguey, onde estão deslocados e quebrados por inúmeras falhas grandes e pequenas. As rochas são de baixa capacidade aqüifera e, com freqüência tem uma salinidade elevada.

As rochas vulcanogénicas e vulcanogénicas-sedimentáres estão preferencialmente desenvolvidas ao sul do território. A seqüência vulcanogénica esta representada por diabasos, andesitos, tufitos, lavas, limolitos, intercalações de calcários, limolitos tufíticos e arenitos.

A seqüência vulcanogénica-sedimentar esta constituída pelas alternações de limolitos tufíticos, arenitos, calcários e xistos silícicos. A vazão dos poços é até $1 \mathrm{~L} / \mathrm{s}$. Consideram-se águas cársticas de fissuras e de estratos fissurais. 


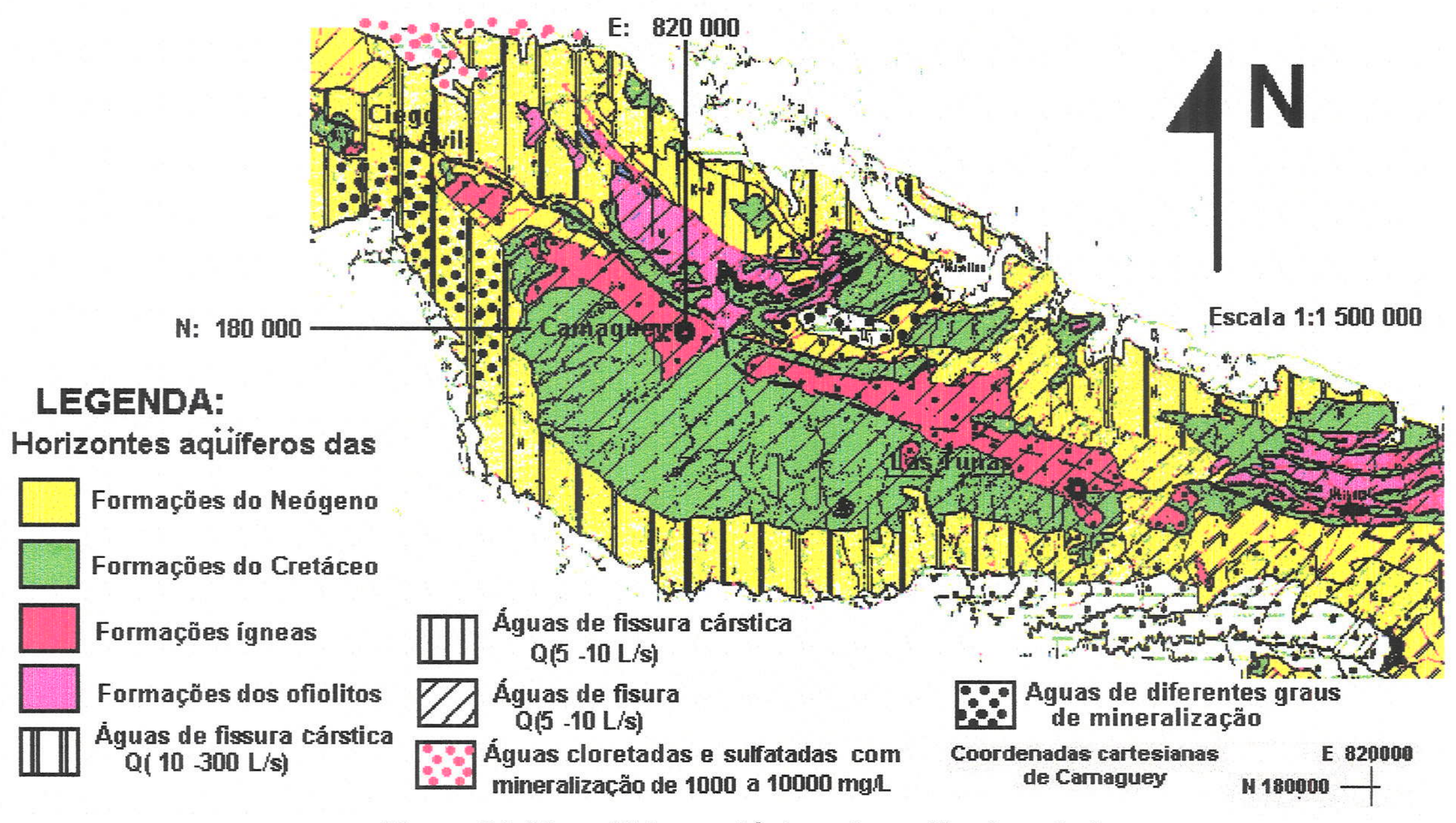

Figura 21. Mapa Hidrogeológico da região de estudo (Fonte : Nuñez Jiménez. 1970. Atlas Nacional de Cuba) 


\section{Paleoceno}

A partir da sua analogia litológica, estes conjuntos estão unificados com os calcários do Cretáceo no Mapa Hidrogeológico da Figura 21, formando um único complexo aqüífero de águas cársticas de fissuras.

\section{Eoceno}

Estão desenvolvidos em todas as províncias e representados por sedimentos terrígenos, vulcanôgenos e carbonatados. Na parte Norte e Noroeste da província Camaguey desenvolvem-se preferencialmente os calcários e ao Sul, as margas. Ao Este da cidade de Camaguey observam-se margas, calcários e rochas carbonatadas magnesianas. As rochas efusivas do Eoceno desenvolvem-se preferencialmente nas partes meridionais da província de Camaguey e províncias mais orientais, representadas por tufas, porfiritos basálticos, calcários tufíticos e xistos tufíticos. Poucas vezes encontram-se intercalações sedimentáres representadas por calcários.

As vazões destes sedimentos são menores que $1 \mathrm{~L} / \mathrm{s}$. Em zonas de deslocamentos tectônicos e tufitos porosos podem se esperar vazões superiores. São consideradas como águas de estrato fissurais.

\section{Oligoceno}

Estão desenvolvidos em todas as províncias, representados por fácies carbonatadas e terrígenas. Nas províncias ocidentais predominam os sedimentos calcários carstificados com vazões entre 30 e $50 \mathrm{~L} / \mathrm{s}$. Nas províncias orientais estão representados por fácies marinha (margas, calcários, dolomitos e anidritos) e continentais (argilas, xistos argilosos e conglomerados). Por isso, nestas últimas províncias, as vazões são pobres, com exceções para os casos onde a espessura do calcário existente permite vazões até os $20 \mathrm{l} / \mathrm{s}$. Consideram-se águas de estrato intersticiais e cársticas de estratos.

\section{Mioceno}

As rochas destes sedimentos estão amplamente representados em todo o território nacional pelas fácies carbonatadas e relacionadas diretamente com os principais recursos de águas subterrâneas do país. Nas províncias mais orientais desenvolvem-se a fácies terrígena.

A fácies carbonatada está representada por calcários brancos e rosas, duros e em algumas partes, muito cavernosos. A espessura dos depósitos varia entre 60 e $300 \mathrm{~m}$. Na província de Matanzas alcança os $600 \mathrm{~m}$.

Ao Norte da província Camaguey os calcários são cavernosos, e, às vezes, argilosos, encontrando-se margas e dolomitos. A estes depósitos estão associados o complexo de águas de estrato fissurais e águas cársticas de estratos, que tem uma ampla extensão e uma grande importância prática como fonte de abastecimento e irrigação, nos limites dos vales das províncias 
de Pinar del Rio, La Habana e Matanzas e na planície das províncias de Villa Clara e Camaguey.

A superfície dos níveis naturais das águas subterrâneas esta inclinada em direção ao mar com cotas entre 4 e 1 metros, e menores, sobre os níveis médios do mar. As vazões dos poços alcançam até $250 \mathrm{~L} / \mathrm{s}$ a mais.

Na parte oeste da província Camaguey, na província Ciego de Ávila, este complexo aqüifero estende-se da costa norte à sul. A linha divisória das águas subterrâneas passa pelas exposições superficiais das rochas anteriores ao Mioceno. Perto da divisória, as alturas do nível das águas têm cotas entre 22 e 24 metros sobre o nível médio do mar, e perto das costas aproximam-se a zero. As vazões variam entre 20 e $200 \mathrm{~L} / \mathrm{s}$ a mais. Freqüentemente tem uma salinidade elevada e distinta composição química. São consideradas como águas cársticas de fissuras.

\section{Quaternário}

Os depósitos estão representados pelas seguintes seqüências :

-areias de grano variado, com cascalhos e argilas.

-argilas e argilas com intercalações de cascalhos e areias.

-formações de pântanos com turfas.

-aluviões de rios e correntes temporais.

-calcários recifais.

Os depósitos da seqüência de areias encontram-se em inúmeros rochedos dos conjuntos de arquipélagos que bordejam a llha de Cuba, o que fazem muito limitado os recursos hídricos nestas reduzidas áreas.

Nas províncias de Villa Clara, Sancti Spíritus, Ciego de Ávila e Camaguey os depósitos de argilas são observados no litoral norte, e menos, no litoral sul. As suas espessuras alcançam entre 10 e $15 \mathrm{~m}$. Provavelmente não contem água subterrânea de importância prática.

Os sedimentos aluviais, representados por cascalhos e fragmentos pouco transportados, estão difundidos nas margens dos rios e pequenos riachos. As espessuras alcançam 5 a $10 \mathrm{~m}$. A importância prática depende da extensão e vazão da corrente superficial sob estudo.

As formações de pântanos com turfas estão distribuídas nas costas norte e sul da llha de Cuba e nas costa de alguns rochedos. Às vezes, estes materiais misturam-se com argilas e carbonatos. Consideram-se águas intersticiais de estratos. 


\subsubsection{Algumas particularidades da hidrogeologia cubana}

Os poços em aqüiferos cársticos apresentam profundidades entre $80-100 \mathrm{me}$ altas vazões. Os poços em rochas fraturadas (cristalinas) são menos profundos, entre $40-80 \mathrm{~m}$, que correspondem à zona de alteração, enquanto o poço perfurado em terrenos arenosos consolidados tem profundidades e vazões baixas.

Devido a esta situação, temos o baixo nível de estudo para um perfil generalizado com poços mais profundo que $100 \mathrm{~m}$ para qualquer formação geológica, embora existam dados locais para profundidades maiores. Por outro lado, devido às heterogeneidades e irregularidades condicionadas pela combinação dos sedimentos calcários e rochas duras fraturadas, à alternação de sedimentos e rochas de diferentes extensões, espessuras e durezas e às suas particulares distribuições e associações locais, fazendo variar os parâmetros hidrogeológicos entre os valores extremos daqueles assumidos para as características petro-físicas particulares das formações analisadas (Tabela 5).

Os perfis mais completos dos aqüíferos estão relacionados com a manifesta intrusão do mar na parte costeira das formações cársticas, os aqüíferos mais produtores que ocupam a maior parte do país.

A Figura 22 adequou o perfil geológico da área de estudo às suposições das características hidrogeológicas gerais. Deve-se notar que as heterogeneidades das formações geológicas não alteram a continuidade do fluxo subterrâneo, o qual drena permanentemente para o mar, segundo permitam as condicionantes regionais específicas. Em sentido geral, a profundidade de estudo hidrogeológico atual não é maior dos $200 \mathrm{~m}$.

Tabela No. 5 . Exemplos da variação dos valores da vazão específica $(q)$ em diferentes formações geológicas da área de estudo.

\begin{tabular}{|c|c|c|}
\hline \multirow{2}{*}{$\begin{array}{c}\text { Formações } \\
\text { Geológicas }\end{array}$} & \multicolumn{2}{|c|}{ Vazão específica, q (L/s/m) } \\
\cline { 2 - 3 } & Valor máximo & Valor mínimo \\
\hline Serpentinitos & 6,67 & 0,44 \\
\hline Granodioritos & 6,8 & 0,01 \\
\hline Andesitos e basaltos & 7,92 & 0,13 \\
\hline Fm. Contramaestre & 8,3 & 7,1 \\
\hline Fm. Guines & 31,5 & 1,3 \\
\hline Fm. Vila Roja & 4,55 & 2,22 \\
\hline
\end{tabular}




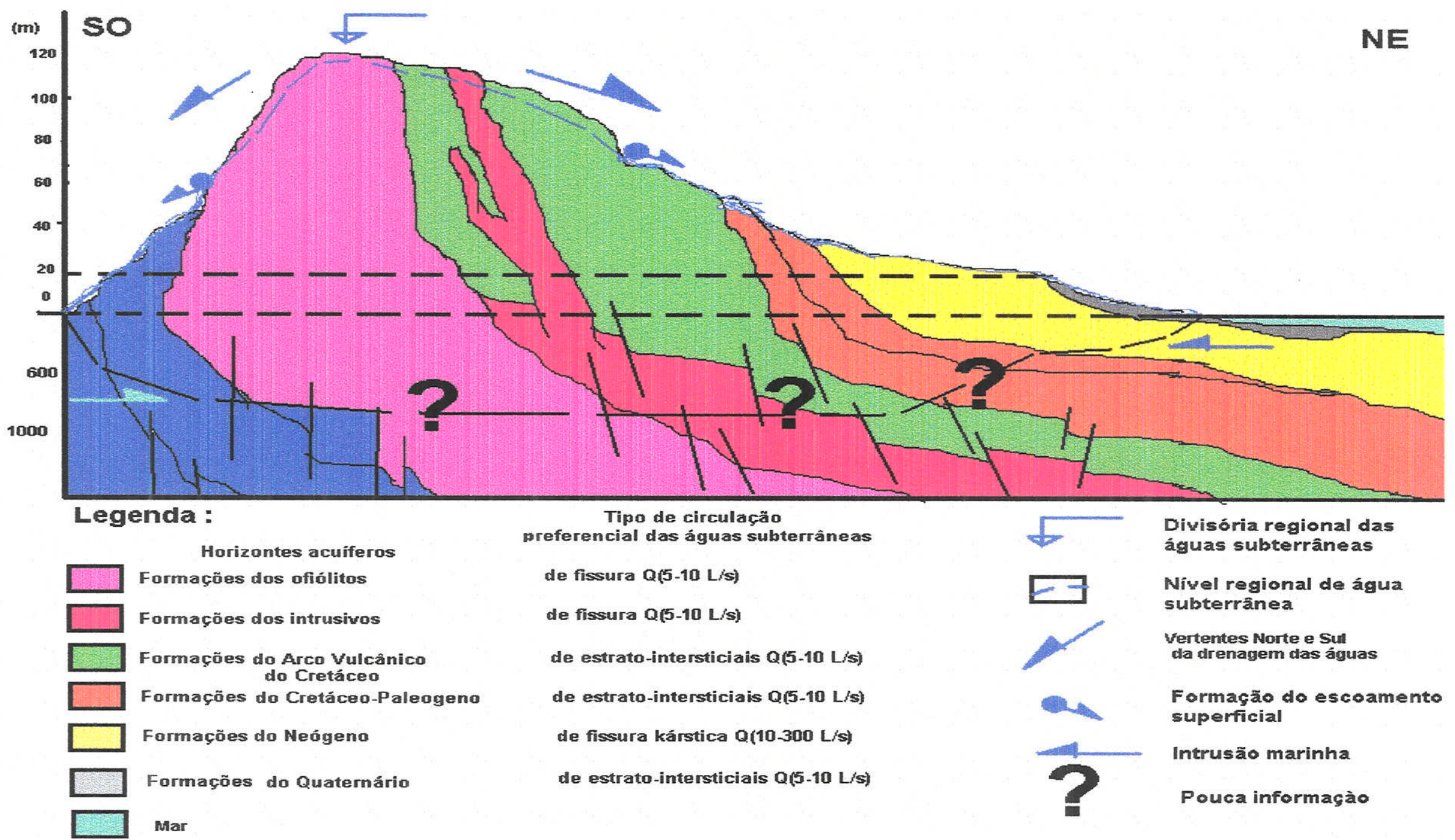

Figura 22. Perfil hidrogeológico esquemático transversal à área de estudo. As escalas vertical e horizontal estão exageradas com 0 fim de destacar os aspectos de maior interesse. 
Pode-se apreciar, muito comum ao resto do país, que o valor particular da vazão específica, mesmo que a Transmisibilidade, não avaliam apenas a aquosidade da rocha, se não, também, as condições das relações estruturais específicas e locais do conjunto rochoso no ponto ou perfuração analisado. A probabilidade maior que dão as rochas cársticas à localização de zonas de alto grau de agretamento, e por isso, maiores aquosidades, tornam-se alvos de melhor e mais econômicas pesquisas hidrogeológicas. Deve considerar-se que as reduzidas extensões que o tamanho geral da Ilha de Cuba permite, mesmo assim, devido à alta pluviosidade e temperatura do clima Tropical Úmido insular, não condicionam a manifestação de similares regularidades hidrogeológicas que podem se apresentar nas litologias continentais equivalentes.

A exceção dos aqüíferos dos sedimentos granulados da bacia do rio Cauto, o maior de Cuba, localizado na província de Bayamo, ao este da área de estudo, a maioria dos aqüíferos em Cuba caracterizam-se por uma composição rochosa dura, agretada ou cavernosa com boa estabilidade das suas paredes nas perfurações feitas. Quando construe-se o poço para a explotação, estas particularidades permitem eliminar o uso dos problemáticos e custosos filtros com cascalho ao seu redor.

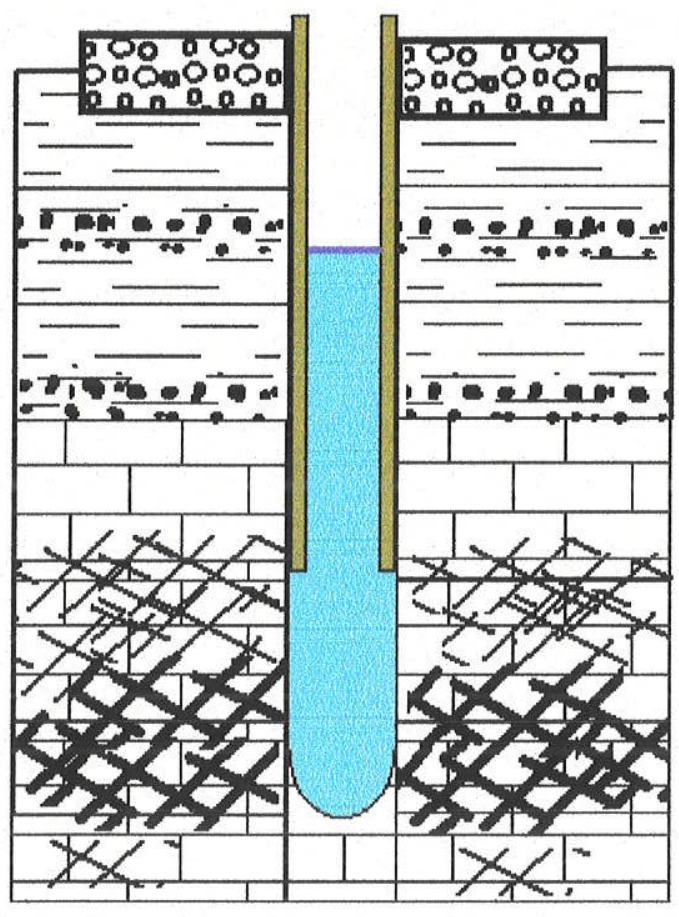

\section{Legenda :}

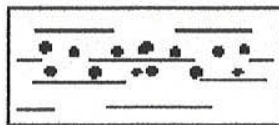

Materiais argilosos

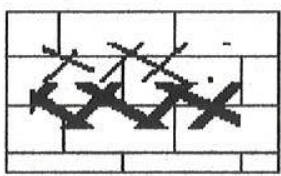

Calcários cársticos

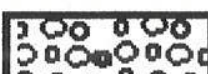

on a on

Base de concreto

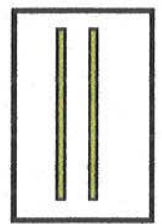

Revestimento

Água dentro do poço

Figura 23. Esquema construtivo típico de um poço em um aqüífero cárstico. Devido à estabilidade das paredes das rochas duras, 0 revestimento apenas emprega-se para evitar a destruição dos materiais mais soltos da cobertura. 
Um exemplo da construção típica nos casos da explotação de água subterrânea em aqüíferos de calcários cársticos ou rochas fissuradas é amostrada na Figura 23.

No caso das águas minerais cuja circulação deve ser mais profunda, evidencia-se que os sistemas de falhas regionais e as suas zonas de agretamentos derivadas, podem ser os melhores contribuintes para as suas localizações e apresentações na superfície, embora possam variar os parâmetros hidrogeológicos, segundo o corte específico no lugar da sua perfuração de explotação.

Tais particularidades induzem a trabalhos de prospeção e avaliações diferentes aos tradicionais métodos hidrogeológicos das outras águas subterrâneas.

O lugar de locação do poço, assim como a sua construção depende da zona específica por onde circula a água mineral sob pesquisa. Tal zona pode ser relativamente estreita com respeito ao corte do horizonte aqüífero restante e, às vezes, pode estar muito mais profunda. A Figura 24 exemplifica a situação.

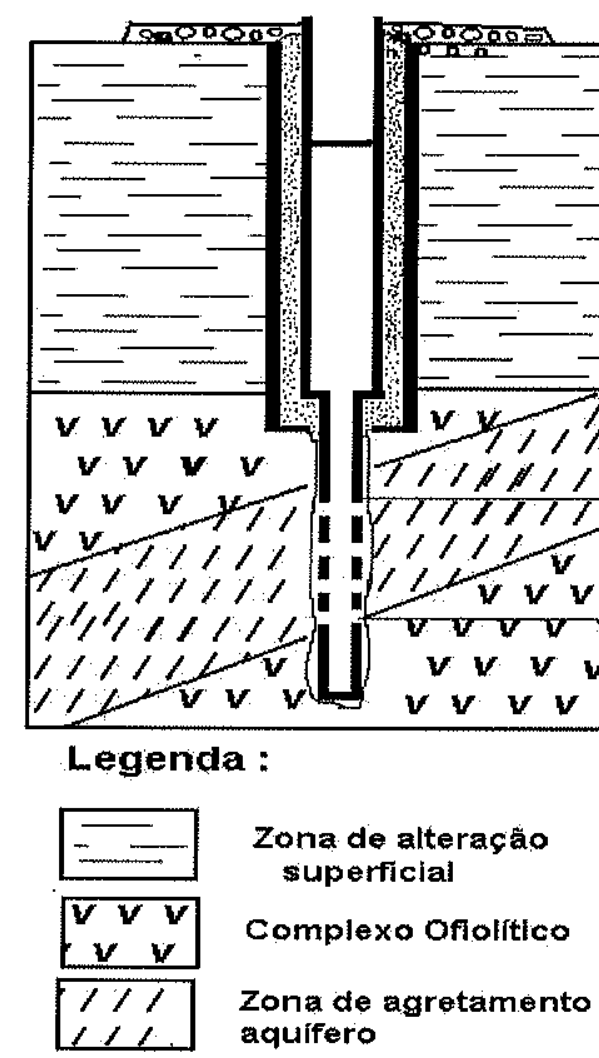

revestimento

20

Espessura do trecho: $40 \mathrm{~m}$.

Diámetro perfuração: $132 \mathrm{~mm}$

Diámetro revestimento: $112 \mathrm{~mm}$

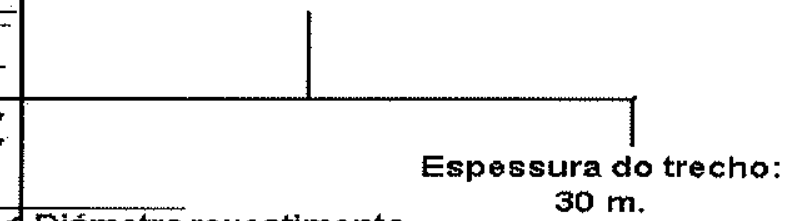

Diámetro revestimento Diámetro perfuração:
filtro: $: 79 \mathrm{~mm}$ Tamanho do trecho: $20 \mathrm{~m}$. $89 \mathrm{~mm}$ Diámetro revestimento: $79 \mathrm{~mm}$

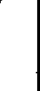

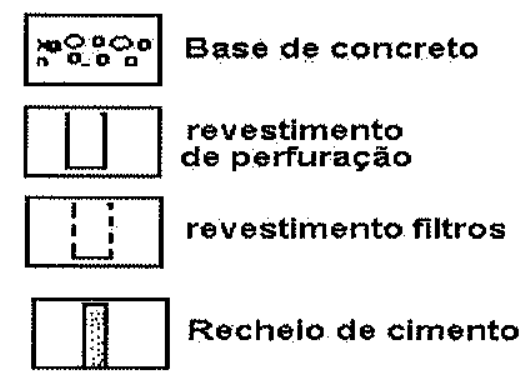

Figura 24. Exemplo esquematizado da construção de o poço de exploração de Peña Azul, Camaguey.

(Fonte : Hipolit et al, 1992) 
O alcance da profundidade planejada (entre mais de $100 \mathrm{~m}$. e na atualidade até os $600 \mathrm{~m}$.) consegue-se com o sistema da perfuração telescópica. O isolamento das águas subterrâneas em contato com as condições ambientais é feito cimentando os trechos superiores e colocando revestimentos "cegos" de perfuração nas partes superiores e inferiores da zona aqüífera. No trecho da zona produtora colocam-se revestimentos que permitem a entrada da água (filtros), que condiciona a entrada controlada apenas das águas minerais, ficando o poço pronto para a avaliação por bombeamento.

Outro aspecto muito particular sobre estas explotações de águas minerais são os poços de prospeção de petróleo, abandonados pelos seus resultados negativos, mas que, pelas suas relações com estes tipos de jazidas, tem apresentado águas de valor medicinal excelente, como são os casos das fontes de águas sulfurosas de El Azufre (Rodriguez, F.,1992) e Veracruz (Rodriguez, F.,1994). Nestes casos, a construção e lugar específico não são controlados pelo hidrogeólogo, favorecendo a pouca e necessária informação hidrogeológica do perfil, aproveitando-se apenas a qualidade avaliada das suas águas minerais.

\subsubsection{Considerações a partir da informação analisada}

As águas minerais têm, entre outras características, singularidades destacadas dentro do entorno das outras águas subterrâneas comuns. $O$ fato de limitar este tipo de jazida às áreas das instalações para sua exploração ou assumir a sua procedência a profundidades desconhecidas, impossibilita descobrir os mecanismos da sua gênesis. Uma generalização dos fatores principais que dominam as águas subterrâneas deve ajudar a precisar as possiveis alternativas que pode condicionar a presencia de um tipo de água mineral dentro os outros tipos comuns de águas subterrâneas.

O alvo do desenvolvimento deste capítulo foi esquematizar esta concepção geral como guia à interpretação dos resultados dos processamentos da documentação existente. A Figura 25 apresenta uma adequação do ambiente hidrogeológico, a partir da informação selecionada dos mapas anteriores, e resumindo, sobre o mapa da região de estudo, o esquema das condicionantes principais que dominam a entrada, circulação e drenagem das águas subterrâneas. Esquematiza também, as possibilidades de apresentação dos tipos hidrogeoquímicos mais característicos, segundo o tipo litológico dominante, a partir da distância à zona de recarga.

A esquematização das condicionantes hidrogeológicas básicas da área de estudo na Figura 25, tem como fim fazer uma concepção dos fatores operantes para melhor interpretar e avaliar os resultados do processamento da informação cadastrada. 


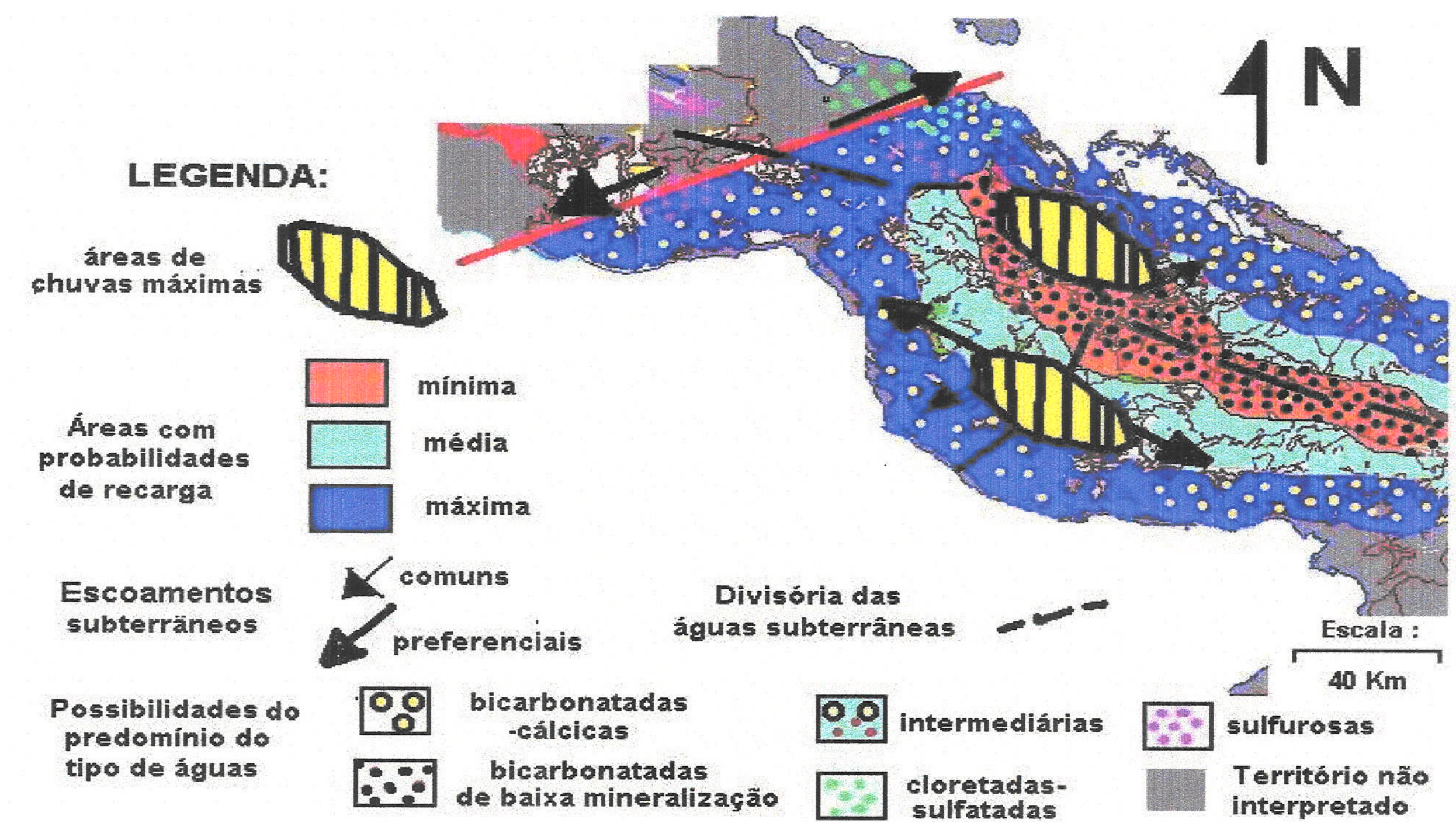

Figura 25. Esquema representativo das condicionantes hidrogeológicas da região de estudo, com base nas informacões qerais existentes. 
Este esquema permite descriminar as condicionantes regionais comuns para determinada fonte mineral, e distinguir as manifestações anômalas dentro do entorno existente. Por outra parte, permite analisar as possibilidades do percurso das águas subterrâneas desde a zona de recarga até a sua zona de drenagem, ou estabelecer as diferentes alternativas para a sua análise posterior.

A imensa maioria das fontes de águas minerais tem uma saída natural como manancial (captada ou não). Isso quer dizer, ainda que não se tenha a certeza documental, que elas são empurradas por algum gradiente hidráulico em equilíbrio com o sistema que as originam. A necessidade de ampliar a exploração devido ao incremento da demanda, seja no próprio manancial ou outras fontes na área, tem acrescentando o uso de poços para estes fins. Quando se explora uma fonte de água mineral mediante poços, a estimativa da vazão depende do rendimento da obra feita, mas o tempo do bombeamento de avaliação, não da margem nenhuma para garantir a estabilidade da qualidade mineral da água a explorar. Precisa-se fundamentar alguns limites úteis para orientar a prospeção e exploração das águas minerais, sobre tudo, se a exploração é mediante poços, pois a drenagem por mananciais, fixa as suas próprias vazões. A explotação de aqüiferos costeiros tem estabelecido não ultrapassar o nível dinâmico de explotação abaixo o nível médio do mar, ou altura zero. Isso nunca significa uma impossibilidade a cumprir, mas significa uma das condicionantes a considerar nas avaliações (Valdés González ,1990).

Outro resultado da análise efetuada é o poder fundamentar preliminarmente uma condicionante hidráulica à exploração das fontes de águas minerais. Aliás do esquema das condicionantes distribuídas no território, foi argumentada uma condicionante aplicável especificamente à explotação. Esta condicionante hidrodinâmica regional permite estabelecer não ultrapassar o nível da explotação das águas minerais, para valores inferiores aos $50 \mathrm{~m}$. de altitude na região de estudo. O cumprimento fiel da condicionante indicada, não exclui a necessária atenção que, às alterações dos fatores hidrogeoquímicos devem ser considerados. Uma conceituação que a tese pretende demonstrar, avaliando a participação de todos os fatores hidrogeológicos, é equilibrar as atenções sobre os limites dos controles estabelecidos, sejam hidrodinâmicos ou hidrogeoquímicos. A Figura 26 apresenta o esquema que ilustra graficamente a fundamentação do limite estimado apenas para a região de estudo. Evidentemente, representa um nível de orientação a ser levado em consideração para a região e que pode se tornar mais perigoso, quanto mais perto da Cobertura Cenozóica encontrar-se a obra de explotação. São poucos os casos na avaliação e explotação das águas minerais que tem podido fundamentar condicionantes de explotação como a apresentada, proveniente da análise dos fatores regionais, sejam como limites ou alternativas.

Os esquemas confeccionados são um ponto de partida para a interpretação das condicionantes que originam as águas minerais, mesmo em qualidade como em quantidade, e, por isso, é pouco útil para discernir fenômenos de influencia muito local. A constatação destes esquemas com os resultados da 
restante informação a processar, permitira precisar melhor as condicionantes de gênese e circulação das águas minerais, dentro do conjunto dos processos que acontecem na circulação geral das águas subterrâneas.
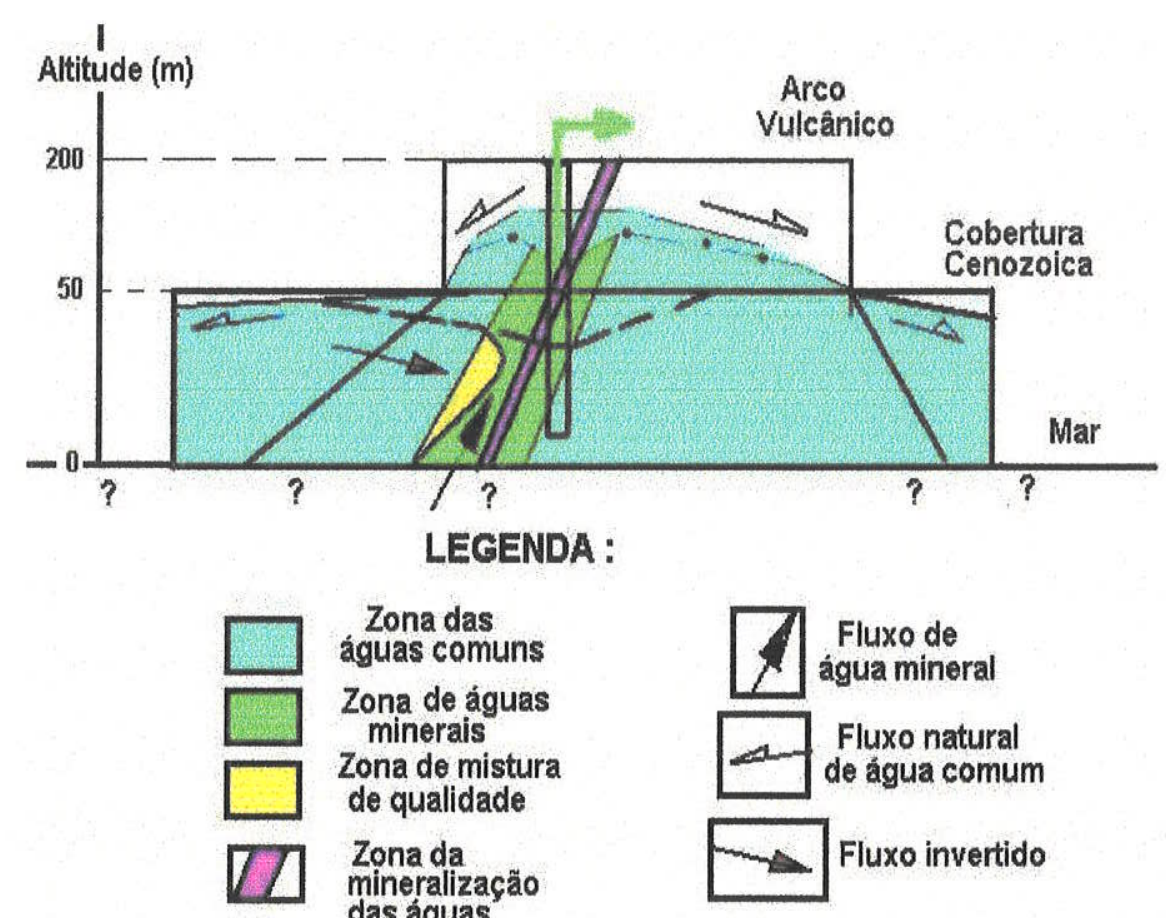

Zona das águas comuns

Zona de águas minerais

Zona de mistura de qualidade

Zona da mineralização das águas

Vazão de água mineral

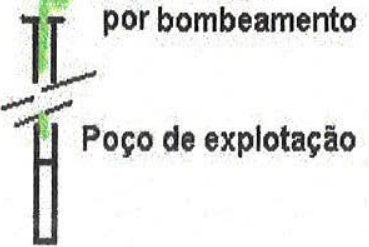

Fluxo de água mineral

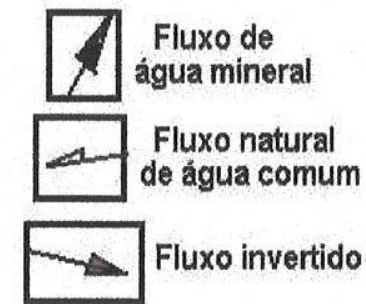

- Nivel natural D. Nivel dinámico

Nivel dinámico inferior aos 50 metros de altitude

Por ser um esquema para ilustrar um aspeto, não da respostas a outras interrogantes geológicas nem hidrogeológicas

Figura 26. Esquema generalizando um possível limite à explotação das águas minerais na região de estudo que, se ultrapassado, pode influir negativamente na qualidade da sua composição química. 


\section{Metodologia}

\section{Metodologia de Campo. Amostragem}

A coleta das amostras utilizadas no trabalho fol feita em 7 poços distribuídos por toda $a$ área de estudo. A escolha destes poços foi feita visando a amostragem de todas as fontes de águas minerais existentes na área de estudo.

A Figura 27 mostra a localização dos poços amostrados.

Diretamente no campo foram medidos os seguintes parâmetros:

.Nível da água (medidor elétrico de nível)

.vazão (recipiente de 3 L e cronômetro)

.Temperatura do ar (termômetro)

.Temperatura da água (termômetro)

.pH (pHmetro portátil)

.Eh (medidor de Eh portátil)

.Condutividade (medidor de condutividade portátil)

STD (medidor de sólidos totais dissolvidos portátil).

Alcalinidade (colorímetro)

$\mathrm{CO}_{2}$ (colorímetro)

Foram coletadas amostras para as seguintes determinações no laboratório s:

Ânions

Cations

$\mathrm{Na}+\mathrm{K}$

$\mathrm{O}^{18}$

Trítio 


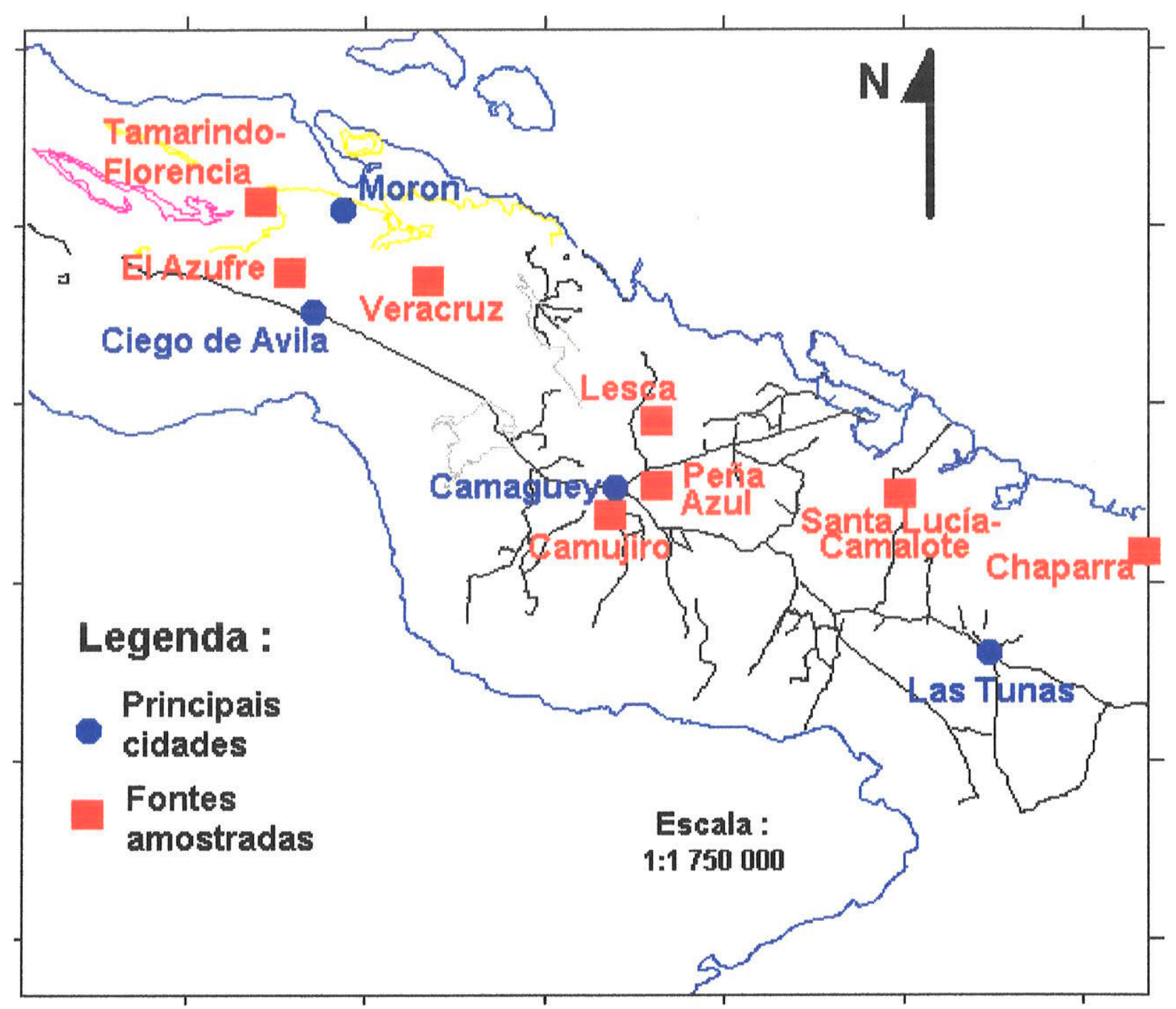

Figura 27 . Localização das fontes de águas minerais amostradas.

Cada amostra coletada foi devidamente acidulada com ácido sulfúrico, para o caso das determinações de $\mathrm{Na}+\mathrm{K}$, e com ácido nítrico, para o caso das determinações dos cátions.

No caso do Trítio, coordenou-se as suas determinações com o o Instituto de Recursos Hidráulicos de La Habana as suas determinações, as quais perderam a sua garantia de qualidade devido a irregularidades nesse instituto e por isso não foram utilizadas no processamento final.

A coleta das amostras para as analises físico-químicas foi feita conforme as normas de CETESB (1988).

A coleta das amostras de água para analises de ${ }^{3} \mathrm{H}$ e ${ }^{18} \mathrm{O}$ foi feita sem adição de qualquer preservativo, utilizando-se apenas frascos de polietileno de $20 \mathrm{ml}$, novos e descartáveis, enxaguados três vezes com a própria água a ser amostrada e cheios ate a boca. A tampa utilizada, também de polietileno, era provida de batoque para a completa vedação do frasco. 


\section{Procedimento de Análise Utilizados em Laboratório}

As análises das amostras de água de poços coletadas durante a campanha realizada em Cuba no mês de dezembro de 1998 foram realizadas nos Laboratórios do Centro de Pesquisa de Águas Subterrâneas do Instituto de Geociências da Universidade de São Paulo (CEPAS, IGc, USP).

As determinações dos ânions $\mathrm{F}^{-}, \mathrm{Cl}^{-}, \mathrm{NO}_{2}, \mathrm{Br}^{-}, \mathrm{NO}_{3}^{-}, \mathrm{PO}_{4}^{-3}$ e $\mathrm{SO}_{4}^{-2}$ foram realizadas pelo processo de cromatografia liquida no aparelho DIONEX 2010i; a análise dos cátions $\mathrm{Na}^{+} \mathrm{e} \mathrm{K}^{+}$foi realizada pelo processo de fotometria de chama, desenvolvido no fotômetro B 262 da Micronal e a análise dos cátions $\mathrm{Cu}^{+2}, \mathrm{~Pb}^{+2}, \mathrm{Zn}^{+2}, \mathrm{Fe}^{\text {total }}, \mathrm{Cr}^{\text {total }}$, $\mathrm{Mn}^{+2}, \mathrm{Ni}^{+2}, \mathrm{Ba}^{+2}, \mathrm{Al}^{+3}, \mathrm{Sr}^{+2}, \mathrm{Ag}^{+}, \mathrm{Cd}^{+2}, \mathrm{Ca}^{+2} \mathrm{e} \mathrm{Mg}^{+2}$ foi realizada pelo processo de espectrofotometria, no Aparelho de Absorção Atômica CG AA7000 BCe.

\section{Processamento da informação utilizada}

\subsection{Composição química das rochas na região de estudo}

Qualquer análise da hidroquímica das águas subterrâneas e os seus resultados derivados não seriam totalmente confiáveis se não fossem comparados com a potencialidade química do conjunto das rochas presentes na região de estudo.

Os materiais utilizados são documentos inéditos que estão em processamento no Instituto de Geologia de Cuba e que foram gentilmente cedidos pelas geólogas Diaz de Villalvilla, L ; Marin, T. e Padrón Martín, M. Por isso, ainda são dados totalmente crús quanto a seu processamento. Estes dados dos conjuntos litológicos das rochas foram determinados apenas para a análise metalogênica da região e agrupados em duas tabelas, uma litológica e a outra, petroquímica. Para poder estabelecer a devida comparação com a informação hidroquímica processada, procurou-se nas tabelas preparadas para a análise metalogênica, o agrupamento específico dos seus dados que homologaram, no tipo de dado e referência geológica, com os registros respectivos das águas, as quais estavam orientadas segundo as formações geológicas de procedência.

Os documentos revisados foram:

A . Tabela Litoquímica com 2519 pontos, organizados respectivamente por número dos pontos, coordenadas, litologia, formação geológica com os resultados das determinações químicas dos microcomponentes metálicos $\mathrm{B}, \mathrm{Be}, \mathrm{Ba}, \mathrm{Co}, \mathrm{Cr}, \mathrm{Cu}$, etc. B . Tabela petroquímica com 1263 pontos, organizados respectivamente por número dos pontos, coordenadas, tipo de rocha (diferenciadas em alteradas ou compactas) com os resultados das determinações químicas dos óxidos seguintes: $\mathrm{SiO}_{2}, \mathrm{TiO}_{2}$, $\mathrm{Al}_{2} \mathrm{O}_{3}, \mathrm{Fe}_{2} \mathrm{O}_{3}, \mathrm{FeO}, \mathrm{MnO}, \mathrm{MgO}, \mathrm{CaO}, \mathrm{Na}_{2} \mathrm{O}$ e $\mathrm{K}_{2} \mathrm{O}$.

C. Tabelas por formações geológicas específicas com o mesmo tipo de informação que a tabela anterior, contendo as seguintes formações:
a. Caobillas (105 pontos)
b. Camujiro (215 pontos)
c. Contramaestre (69 pontos)
d. Piragua (109 pontos)
e. Sierra (79 pontos) 
A revisão de toda a informação apresentada para o objetivo pretendido, concluiu o seguinte:

A tabela nomeada de $\mathrm{A}$, litoquímica, resultava improcedente no que se refere às determinações existentes pois não guardam similitudes com o tipo de informação utilizado para as águas.

A informação da tabela nomeada de $B$, petroquímica, ajustava-se à informação equivalente processada das águas no que se refere aos cátions, em particular, os óxidos de $\mathrm{Ca}, \mathrm{Mg}, \mathrm{Na}$ e $\mathrm{K}$.

A tabela nomeada de $C$, similar à $B$, no que se refere aos cátions, compreendia apenas as formações relacionadas com o Arco Vulcânico. Entre elas, selecionou-se a Formação Caobilla por conter uma amplitude representativa maior de todas as rochas participantes do tipo efusivo.

Foi selecionada definitivamente, para comparar a análise da composição química das rochas com as análises químicas das águas a Tabela $B$, junto à Tabela $C$ (a). Considerou-se que a Tabela $B$, além de conter os elementos essenciais das determinações químicas catiônicas na forma de expressão conveniente, possuía o grupo completo das rochas existentes na região de estudo (metamórficas, ígneas e sedimentárias). Neste sentido, devido à qualidade do dado selecionado, aplicou-se o Enfoque Estatístico (Drever, 1988) para tentar estabelecer uma associação de causa e efeito. Devido que nenhuma destas tabelas não terem as determinações químicas também relacionadas especificamente com os minerais das rochas da região, não houve a possibilidade de se efetuar as análises pelos enfoques do Balance de Massas e Termodinâmicos.

O método de análise estatístico utilizado para as rochas, tem que secombinar, também, com similares critérios e esquemas aos utilizados para o processamento das águas para a sua comparação posterior.

Pode se dizer que são poucos os exemplos existentes na literatura especializada sobre metodologias de processamento da composição química das rochas para a análise específica da gênese dos tipos hidroquímicos das águas que pudessem aplicar-se na região sob estudo. Em geral, na literatura, utilizam-se para tais comparações, tabelas que relacionam as composições de águas que circulam pelos distintos tipos litológicos, com tabelas de valores meios ou porcentos do peso dos componentes químicos das rochas ou minerais principais (Castany,1968; Chebotarev,1955; Custodio,1976; Davis, 1966; Drever,1988; Matthess,1982; Schoeller,1962; Szikszay,1993).

Por outro lado, a abordagem dos gráficos utilizados para a interpretação petroquímica e mineralógica da análise das rochas, não está estendida às águas. O uso de gráficos de similares estruturação ou distribuição para a comparação das correspondências químicas rochas/águas de uma mesma região não é freqüente. Mas, também não existem referencias que argumentem a impossibilidade de preparar-los para o seu uso comparativo. 
A concepção dos princípios da construção dos diagramas triangulares, utilizados para as águas, permite também, sua aplicação aos resultados da composição química das rochas. O uso deste tipo de diagrama triangular "é muito menos restritivo que os de PIPER e DUROV porque podem comparar qualquer combinação de parâmetros utilizando qualquer unidade de concentração" (Waterloo Hydrogeologic Software, 1998). Por outro lado, Matthess, 1982, aborda a possibilidade do uso de gráficos semilogarítmicos para analisar a correspondência entre os valores dos componentes diluídos, em meq/l, com pesos ou fórmulas moleculares das águas. Neste sentido, Schoeller, 1962, compara a relação de pesos e porcentos de pesos de óxidos das rochas, com valores em meq/l dos componentes homólogos das águas.

Com o apoio nas experiências referidas, e como a informação química das rochas apenas tem valores dos óxidos dos cátions, considerou-se apropriado utilizar os diagramas triangulares e os gráficos semilogarítmicos de Schoeller para a sua comparação com os gráficos similares utilizados para as águas. Assim aplicados, a avaliação das relações rochas/águas basear-se-iam em: 1) O uso dos diagramas triangulares para associar a regularidade das proporções do $\mathrm{Ca}, \mathrm{Mg}$ e $\mathrm{Na}$ das rochas com os mesmos componentes das águas. 2) O uso dos gráficos semilogarítmicos, de Schoeller, para associar as variabilidades das proporções e relações entre $\mathrm{K}, \mathrm{Mg}, \mathrm{Ca}$, $\mathrm{Na}, \mathrm{SiO}_{2}$ e $\mathrm{Fe}_{2} \mathrm{O}_{3}$ (usado como $\mathrm{Fe}$ ) das rochas com os mesmos componentes diluidos nas águas. Neste último aspeto, as associações seriam feitas sem tentar estabelecer correspondências diretas com os valores das concentrações das rochas e águas, porem permitindo comparar qualitativamente a proporção de valores dos componentes apresentados nos gráficos entre os distintos tipos de rochas.

O resultado do processamento assim efetuado, totalmente qualitativo, permitiria definir a correspondência e proporcionalidade catiônica existentes entre o tipo litológico e as águas que circulam ou provem dessa litologia na região. A constatação da veracidade deste enfoque seria a comparação das correspondências rochas/águas que a literatura internacional estabelece para os mesmos componentes catiônicos de similares rochas e águas. Se verificado, permitiria fundamentar as interpretações hidrogeoquímicas específicas e argumentar sobre algumas diferenças particulares. Permitiria, ainda, exemplificar uma via de análise regional, com a utilização específica da informação litológica e de águas existentes numa área de estudo.

Para o processamento recorreu-se ao programa HYDROWIN, versão 3,0 e AQUACHEM com a finalidade de conseguir esquemas similares de comparação entre os resultados da composição química das rochas e as águas subterrâneas. A seleção dos tipos litológicos a processar foi estabelecida sob a semelhança dos mesmos tipos litológicos reportados para as águas processadas. Dentro de cada tipo litológico específico, escolheram-se os diferentes resultados tabelados para a faixa da variabilidade das amostras reportadas (compacta e alterada) e discriminaram-se, como não representativos, os valores que saíssem dos resultados do conjunto majoritário.

Assim avaliados, escolheram-se os pontos representativos das determinações químicas dos serpentinitos, granitos, granodioritos, dioritos, basaltos, lavas, tufos, quartzitos, rochas carbonatadas, argilas e a formação geológica Caobillas, que compreendem os mesmos conjuntos selecionados para as águas (Vide 4.2.1.1. Descrições das Unidades Geológicas Principais). 


\subsection{Cadastramento das águas subterrâneas da região}

Utilizou-se a documentação básica levantada das três províncias, contidas no trabalho de generalização hidrogeológica (Rodriguez et al, 1996), referido no capítulo III.

O trabalho contem para as distintas províncias, as quantidades de pontos a seguir:

Ciego de Avila : 1318

Camaguey: 2852

Las Tunas : 1434

Total Geral : $\quad 5604$

O critério seletivo foi agrupar os pontos existentes das águas segundo os conjuntos litológicos e formações geológicas representativos das idades dos processos geológicos. O total dos pontos registrados em cada província, agrupados por litologias e formações geológicas, não tem a totalidade das informações hidrogeológicas requeridas e, em particular, nem todos tinham a informação da composição hidroquímica completa.

As quantidades dos pontos por formações geológicas selecionadas com a totalidade da informação hidroquímica necessária (condutividade, $\mathrm{pH}, \mathrm{STD}, \mathrm{Cl}, \mathrm{HCO}_{3}, \mathrm{SO}_{4}, \mathrm{Ca}$, $\mathrm{Mg}, \mathrm{Na}$ e K) foram:

Formações Geológicas No. de Pontos

\section{Complexo Ofiolítico}

Serpentinitos: .71

Peridotitos :

Gabros:

2. Complexo Î́gneo

Granodioritos de Camaguey: 278

Granitos de Camaguey: .36

Andesitos e basaltos de Camaguey:............................17

Granodioritos de Las Tunas: $\quad$................................260

Andesitos e basaltos de Las Tunas:............................... 31

3. Formações do Arco Vulcânico

Fm. Contramaestre (cnt):

Fm. Caobillas (co): 172

4. Formação da Cobertura Cenozóica

Fm. Vertientes(vs) do Paleógeno 99

Fm. Guines(gi) do Neógeno. Ciego de Avila: 258

Fm. Guines(gi) do Neógeno. Las Tunas: .384

Fm. de Calcários e margas do Neógeno. Camaguey:....44

Fm. Vila Roja(vl) do Quaternário. Ciego de Avila: ...... 80

Total processado: .2040 
Os dados foram revisados no que diz respeito ao erro e a sua qualidade, considerando-se só aqueles com valores abaixo de $10 \%$ da diferença entre a somatória dos meq/L dos cátions e ânions, o que reduziu os pontos de 2040 a 736 .

A associação quimismo rocha/água seria interpretada a partir apenas dos resultados das correspondências dos cátions, que são os únicos elementos comuns entre ambas as partes, ficando os ânions para a interpretação específica das águas. Assim processados os dados petrográficos e hidroquímicos, a interpretação estaria condicionada na apreciação da conjugação ou não das similaridades e diferenças esperadas nas comparações específicas entre cada conjunto litológico e as suas respectivas águas. Para evitar a confusão que pudesse provocar o excesso de informação a comparar, procedeu-se iniciar a análise comparativa com os conjuntos litológicos de maior uniformidade e reconhecida simplicidade da sua composição química (peridotos, granitos e granodioritos,entre as rochas ígneas, e, calcários, entre as sedimentares). O resultado positivo seria a constatação dos resultados obtidos com os exemplos similares reportados na literatura especializada. Se assim constatados, os resultados dos casos mais complexos, pela alta mistura da variações petrográficas, como os relacionados com as formações Contramaestre, Caobilla, Vertientes e Vila Roja, estariam avaliados pela confiabilidade estabelecida pelos conjuntos da litologia simples.

\subsection{Considerações sobre a representatividade dos resultados}

O método científico de análises utilizado foi essencialmente indutivo-empírico para a classificação e interpretação dos resultados dos processamentos, mas houve necessidade também de se recorrer ao método dedutivo para aplicar os resultados à interpretação global dos mecanismos do sistema hidrogeológico das águas minerais. As poucas tentativas existentes de generalizar as particularidades hidrogeológicas das águas minerais na escala regional a partir do contexto das águas subterrâneas comuns (Alvarez et al, 1996 ; Brodermann, 1948) e a pobre estruturação da metodologia hidrogeoquímica para abordar esta situação (itens III. 4 e III. 4.1), obrigou o autor a estabelecer o seu próprio caminho de abordagem e solução aos objetivos propostos. A necessidade de ultrapassar o nível de incerteza existente na metodologia hidrogeoquímica em geral e daquela relacionada com as águas minerais em particular, exigiu esclarecer no capítulo III, que o presente trabalho carecia do apoio metodológico esperado e fundamentar os procedimentos utilizados para as análises e interpretação dos resultados alcançados.

Um outro aspecto importante sobre o qual foi mantida atenção especial refere-se à qualidade e regularidade da procedência dos dados. Os dados utilizados das águas foram aqueles reportados no documento referido ao principio, que indicavam às águas como circulantes pela formação específica, mas que não eliminava a possibilidade de que particularmente, como ponto amostrado, essas águas pudessem provir do centro do referido conjunto ou, das suas bordas ou limites laterais com conjuntos vizinhos. Também não eliminava a possibilidade que essas águas estivessem misturadas no próprio poço com outras águas.

Por isso, é necessário esclarecer que todos os pontos documentados têm em comum que suas amostras foram coletadas na superfície do seu nivel de água e nenhuma a determinada profundidade dentro da coluna de água existente. 
Por outro lado, a localização superficial do ponto em determinada litologia ou formação geológica, não exclui as possibilidades, até a profundidade perfurada, de atravessar completa ou parcialmente a litologia referida, seja no contato superior ou inferior. No caso de atravessar parcialmente, da lugar à possibilidade de circulação de águas de outros tipos litológicos não reportados. Os poços representados em cada ponto documentado, sejam localizados no centro ou na periferia do maciço geológico descrito, são obras cuja construção não isolam água particular da formação geológica ou tipo litológico perfurado reportado, sendo então, sua coluna de água, representativa da mistura geral das águas existentes até a profundidade perfurada. Mas, sempre representando, misturada ou pura, sua referência superficial. Estas regularidades da procedência e coleta das amostras reportadas favorecem as análises porquanto uniformiza a qualidade dos conjuntos dos resultados a interpretar.

A confiabilidade sobre a constatação do tipo hidroquímico representativo do tipo litológico avaliado, sob estas condições indicadas da procedência do dado, viria apoiada pelo meio predominante do tipo hidroquímico resultante no conjunto das águas subterrâneas proveniente dessa litologia processada. É evidente sob este enfoque que, onde foi coletada uma amostra de um determinado tipo litológico reportado, o tipo hidroquímico resultante reflita o tipo litológico se a coluna de água representa a circulação predominante desse meio. No caso contrário, se a circulação predominante refletida na coluna de água do poço está subordinada a outras influencias das condições específicas locais ou de contorno do aqüífero, 0 tipo hidroquímico resultante, não correspondera à litologia reportada.

Estas considerações assumidas para a confiabilidade da representatividade dos pontos na interpretação hidrogeoquímica regional, já foram aplicadas pelo autor em pesquisas anteriores e confirmadas pelos resultados práticos (Valdés González, 1976; 1977; 1985; 1990).

Neste sentido, como é fundamentado no item III.4.3, considerou-se o predomínio do tipo hidrogeoquímico resultante como o representativo do tipo de água de cada conjunto litológico e, os outros tipos hidroquímicos coexistentes como o tipo resultante avaliado, representativo dos tipos hidrogeoquímicos relacionados com os predomínios das misturas com outras águas subterrâneas, causados pelas influencias da circulação das águas nos arredores do poço e nos contornos ou limites da formação ou tipo litológico do ponto reportado.

Por isso, procurou-se ser cuidadoso na precisão da qualidade do dado que podia influir nas interpretações definitivas. Nesse sentido, o volume inicial dos dados das águas reportadas ficou tão reduzido, porém sem dúvida alguma, mais preciso e de melhor qualidade.

A revisão da qualidade, e o processamento hidrogeoquímico foram com os programas HYDROWIN, versão 3,0 e AQUACHEM, para as determinações das suas características paramétricas e o programa SURFER 32 foi utilizado para a localização e distribuição dos dados no território em estudo.

Os fundamentos da utilização destas particularidades e mesmo os critérios e enfoques para as avaliações dos componentes compreendidos estão nos itens III (5.1,5.2 e 5.3). 


\section{Campanha de amostragem}

\section{Amostragem}

$\mathrm{Na}$ campanha de campo foram amostrados aquelas águas consideradas como minerais e/ou termais na região de estudo.

$\mathrm{Na}$ província de Ciego de Avila foram amostrados as seguintes águas: Tamarindo, El Azufre e Veracruz, que são apresentados na Figura 28

$\mathrm{Na}$ província de Camaguey foram amostrados as seguintes águas: Camujiro, Peña Azul, Tínima e Paso de Lesca. A Figura 29 apresenta a sua locação no mapa.

$\mathrm{Na}$ província de Las Tunas foram amostrados as águas dos poços em Chaparra,.A Figura 30 apresenta a sua locação no território.

Diretamente no campo foram medidos os seguintes parâmetros:

.Nível da água ( com medidor de nível elétrico)

.Vazão ( recipiente de 3 L e cronômetro)

.Temperatura do ar (com termômetro)

.Temperatura da água(com termômetro)

.pH (com pHmetro portátil marca Orion)

.Eh (com medidor de de potencial de oxiredução portátil Orion)

.Condutividade elétrica (com medidor de condutividade elétrica portátil marca Orion com resolução até $1999 \mu \mathrm{S} / \mathrm{cm}$ e até $19999 \mu \mathrm{S} / \mathrm{cm}$. )

Solidos Totais Dissolvidos com medidor de STD portátil marca Orion, com resolução até $1000 \mathrm{mg} / \mathrm{L}$ e até $10000 \mathrm{mg} / \mathrm{L}$. Alcalinidade(colorímetro)

Alcalinidade de bicarbonatos e carbonatos, pelo método colorimétrico com titulação.

$\mathrm{CO}_{2}$ dissolvido, através do método colorimétrico titulação.

Em seguida foram coletadas amostras de água para análises laboratoriais (Vide capítulo V) para determinação dos seguintes parâmetros:

Ânions principais

Cátions principais

Metais pesados

Elementos traços e isótopos

${ }^{18} \mathrm{Oe}^{2} \mathrm{H}$

${ }^{3} \mathrm{H}$ 


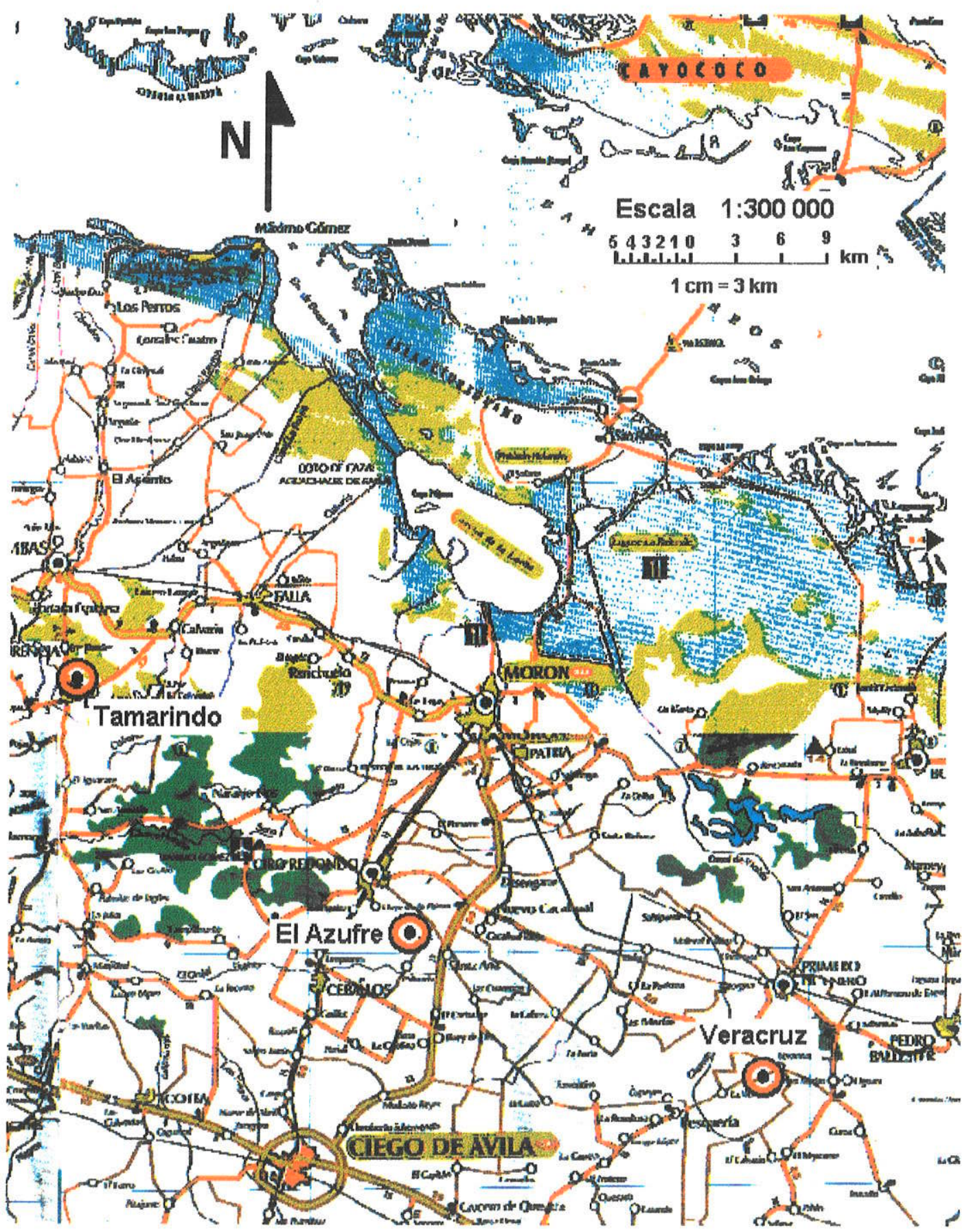

Figura 28 . Localização das fontes pertencentes à província de Ciego de Avila. Adecuado do Diretório Turístico de Cuba

(Fonte: Jane Martin, 1998) 


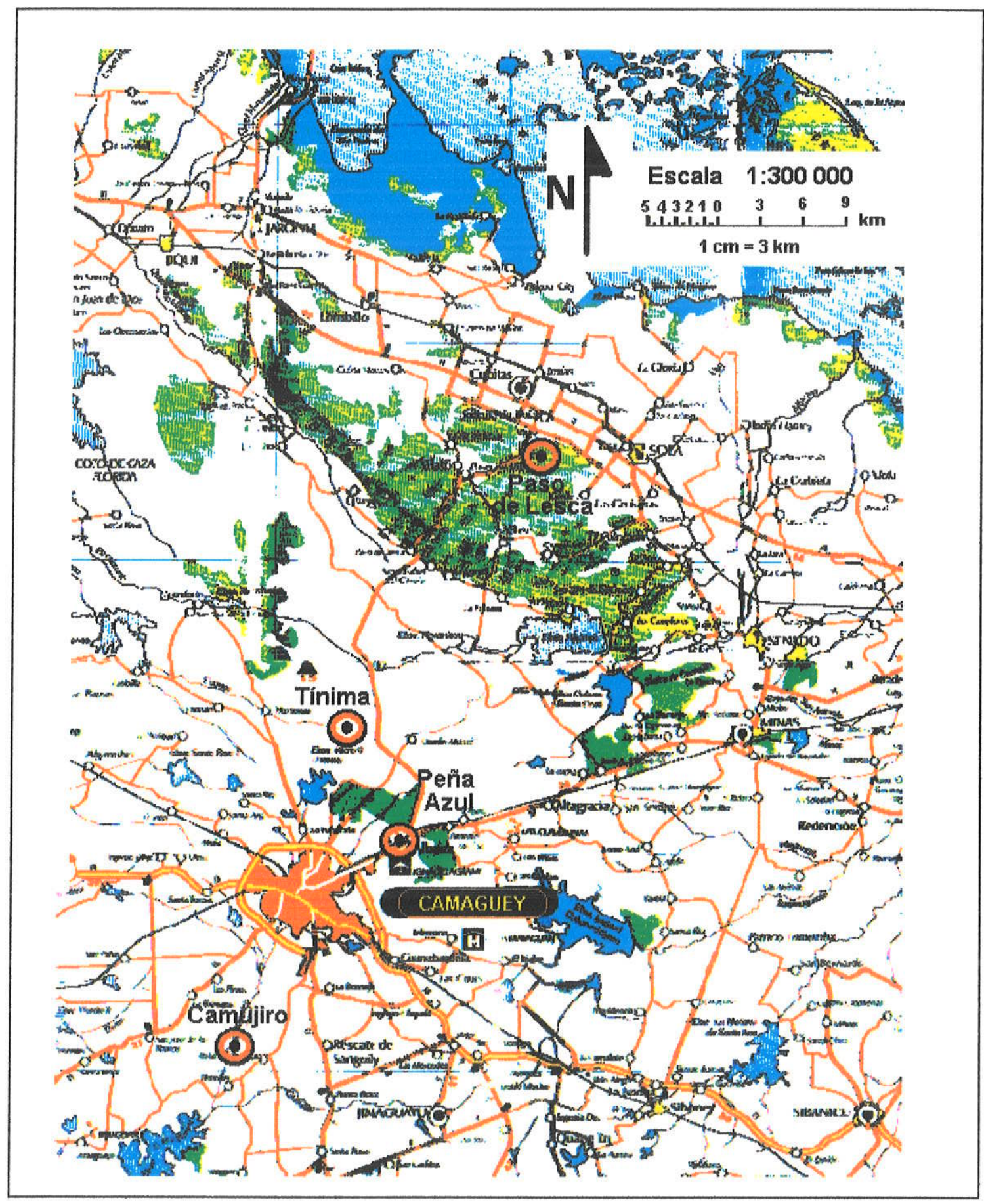

Figura 29. Localização das fontes pertencentes à província de Camaguey. Adecuado do Diretório Turístico de Cuba.

(Fonte: Jane Martin, 1998) 


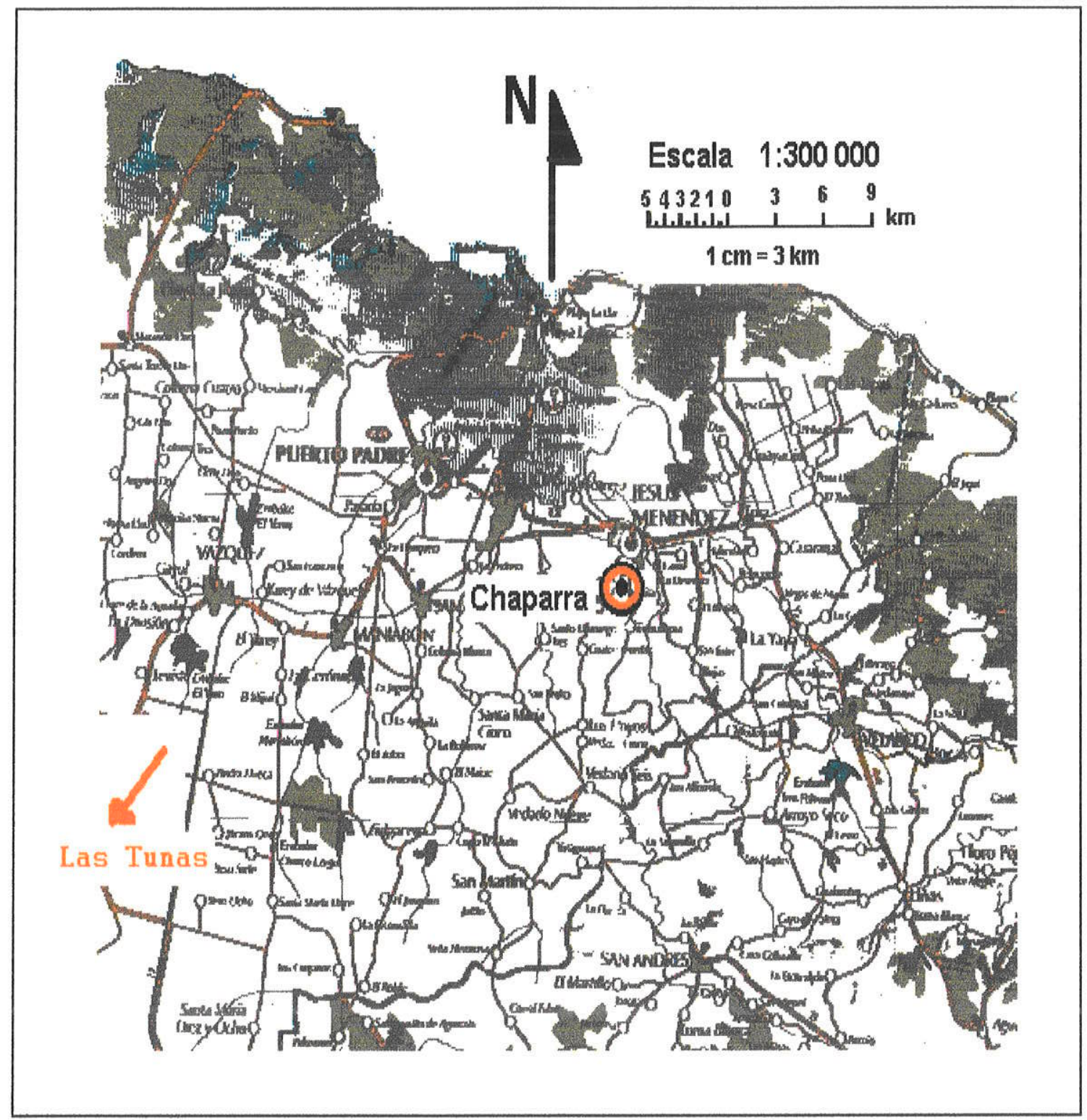

Figura 30. Localização das fontes pertencentes à província de Las Tunas. Adecuado do Diretório Turístico de Cuba.

(Fonte: Jane Martin, 1998) 


\section{Descrição dos pontos amostrados}

\section{Ponto P-1}

Veracruz, província de Ciego de Ávila, Cuba.

Data de amostragem: 7.12 .98

Poço artesiano, com intermitências. Protegido por perímetro sanitário.

Temperatura do ar: $27^{\circ} \mathrm{C}$

Temperatura da água : $26^{\circ} \mathrm{C}$

$\mathrm{pH}: 7,6$

Eh : $-330 \mathrm{mV}$

Condutividade elétrica: $9500 \mu \mathrm{S} / \mathrm{cm}$

Vazão $(Q): 2,68 \mathrm{~L} / \mathrm{min}=0,045 \mathrm{l} / \mathrm{s}$

STD : $6175 \mathrm{mg} / \mathrm{L}$

Alcalinidade:

$\mathrm{HCO}_{3}{ }^{*}=213,5 \mathrm{mg} / \mathrm{L}$

Dados do poço:

Profundidade total : $166 \mathrm{~m}$.

Perfil geológico:

0----145 m. : Formação Guines (calcários do Mioceno). Horizonte aquífero freático com Q 10 L/s. Água de tipo bicarbonatada cálcica com teor de sólidos totais dissolvidos entre $500-1500 \mathrm{mg} / \mathrm{L}$.

145-166 m : Formação Vertientes (argilas e arenitos do Paleogêno). Horizonte impermeável com $Q<<1 \mathrm{~L} / \mathrm{s}$. Água de tipo cloretada sódica com STD entre 1000$1500 \mathrm{mg} / \mathrm{L}$.

$166 \mathrm{~m}$ : Zona de falhas. Entrada de água com elevada mineralização e cheiro de $\mathrm{H}_{2} \mathrm{~S}$. Horizonte aqǘfero artesiano com $\mathrm{Q}=1 \mathrm{~L} / \mathrm{s}$. A água eleva-se até $9 \mathrm{~m}$ acima do nivel do terreno.

A falha encontrada no poço está associada a jazidas de hidrocarbonetos . A sua direção é: SE-NW com uma inclinação $70^{\circ} \mathrm{SW}$ (Rodriguez, 1994).

Esta água foi descoberta em 1980 durante os trabalhos do Levantamento Geológico 1: 50000 realizados na província. O objetivo principal da perfuração foi alcançar as formações ígneas do Arco Vulcânico, atravessando a bacia sobreposta da Cobertura Cenozoica do Neógeno. Não cumprindo os objetivos 
planejados o poço foi abandonado e ficou livremente jorrando até o seu aproveitamento como água medicinal (Rodriguez, 1994).

Durante 4 anos de monitoramento, entre 1990 e 1994, observou-se que tanto a vazão como a mineralização da água se mantiveram bastantes estáveis.

Atualmente, funciona em Veracruz um pequeno balneário para tratamento tópico de doenças da pele, em especial, psoriasis. Tem uma médica permanente que supervisiona a aplicação correta dos tratamentos. O grande problema é que o balneário dispõe somente de duas "pseudobanheiras", cuja água é trocada a cada sete dias.

\section{Ponto P-2}

El Azufre, província de Ciego de Ávila, Cuba.

Data de amostragem : 8.12 .98

Poço artesiano, e, totalmente abandonado em meio a plantações de cana de açúcar.

Temperatura do ar: $33^{\circ} \mathrm{C}$

Temperatura da água : $29^{\circ} \mathrm{C}$

$\mathrm{pH}: 8,6$

Eh : $-175 \mathrm{mV}$

Condutividade elétrica: $4000 \mu \mathrm{S} / \mathrm{cm}$

Vazão (Q) : 4,0 L/s

$\mathrm{STD}: 2600 \mathrm{mg} / \mathrm{L}=2,6 \mathrm{~g} / \mathrm{L}$

Alcalinidade:

$\mathrm{HCO}_{3}{ }^{-}=30,5 \mathrm{mg} / \mathrm{L}$

Dados do poço:

Profundidade total: $931 \mathrm{~m}$.

Perfil geológico:

0-320 m. Formações: Arroyo Palmas(calcários, argilas e areitos do $\mathrm{N}^{1-2}$ ), Ferrer (calcários e clastos biodetríticos do $\mathrm{Pg}_{2}{ }^{3}$ ), Vertientes (margas, calcários e gravelitos do $\mathrm{Pg}_{2}{ }^{2}$ ), Jimaguayú (calcários biogenos e margas do $\mathrm{K}_{2}{ }^{\mathrm{m}}$ ) e Durán (conglomerados e arenitos, margas e calcários do $\mathrm{K}_{2}^{\mathrm{cp}-\mathrm{m}}$ ).

320-931 m. Formação Caobillas (rochas vulcanógenas do Cretácico) 
À profundidade de $336 \mathrm{~m}$. aparece a água sulfurosa e continua surgindo até os $931 \mathrm{~m}$. finais do poço. Isso acontece ao cortar zonas de intenso falhamento.

Considera-se no setor de estudo:

O horizonte aqüifero freático formados pelas formações geológicas: Jimaguayú, Vertientes, Ferrer e Arroyo Palmas.

O horizonte aqüífero artesiano constituído pelas rochas vulcânicas da formação Caobillas. Tem-se determinada relação hidráulica entre ambos horizontes devido às fraturas existentes, pois encontram-se águas com teores notáveis de $\mathrm{H}_{2} \mathrm{~S}$ nas profundidades de 125 e $165 \mathrm{~m}$.

O poço, até os $84,5 \mathrm{~m}$. tem o revestimento protegido com cimento

Este poço foi perfurado em 1969 para prospeção de petróleo, por isso que as descrições litológicas não tiveram definidos os contatos entre as formações perfuradas. A gêneses destas águas é associada às jazidas de hidrocarbonetos existentes na região (Rodriguez, 1992).

Atualmente, o jorro permanente origina um pequeno riacho que serve de bebedero para gado, mas a suas águas são utilizadas também pela vizinhança na cura de doenças da pele, conforme informações orais da população local.

\section{Ponto P-3}

Tamarindo, província de Ciego de Ávila, Cuba.

Data de amostragem : 8.12 .98

Poço localizado no perímetro urbano de Tamarindo. As autoridades estavam fazendo o perímetro de proteção sanitário e construindo uma piscina abastecida com a água do poço. Este poço foi perfurado em 23.02.79 para o uso balneológico da população local.

Temperatura do ar : $24^{\circ} \mathrm{C}$

Temperatura da água : $26,8^{\circ} \mathrm{C}$

$\mathrm{pH}: 8,8$

Eh : $-198 \mathrm{mV}$

Condutividade elétrica: $1200 \mu \mathrm{S} / \mathrm{cm}$

Vazão $(Q)$ : Poço não artesiano e como não tinha bomba, não foi possível medir a vazão.

STD : $780 \mathrm{mg} / \mathrm{L}$ Alcalinidade:

$-\mathrm{HCO}_{3}{ }^{-}=164,7 \mathrm{mg} / \mathrm{L}$ 
Dados do poço:

Profundidade aproximadamente de $30,0 \mathrm{~m}$

Como não encontramos o perfil hidrogeológico do poço, apresentamos um perfil que serviu para o projeto do poço (Marsal, 1986).

A área está representada por:

1.Complexo de zonas aqüíferas por fissuras e fraturas do Cretáceo Superior

2.Complexo aqüífero por fissuras e fraturas do Paleoceno.

O primeiro complexo subdivide-se em: a) zonas aqüíferas do fissuramento principal e b) zonas aqüiferas do fissuramento secundário.

A composição química sulfurosa destas águas é devida a processos bioquímicos relacionados com a ação das bactérias sulfato redutoras.

Estimam-se nestes tipos de aqüíferos vazões entre 5 e $10 \mathrm{~L} / \mathrm{s}$, variação de teores de sólidos totais dissolvidos entre 400 e $1500 \mathrm{mg} / \mathrm{L}$ e, fundamentalmente teores de $\mathrm{H}_{2} \mathrm{~S}$ entre 10 e $24 \mathrm{mg} / \mathrm{L}$.

Atualmente, devido ao deficiente serviço de abastecimento de água na cidade, uma grande parte da população usa a água do poço para consumo humano.

\section{Ponto P-4}

Banhos de Camujiro, provincia de Camaguey, Cuba.

Data de amostragem : 14.12 .98

É uma antiga fonte medicinal conhecida desde o século XVIII. Uma lenda conta que o médico de Napoleón Bonaparte, Dr. Antimarchi, banhava-se nestas águas.

Temperatura do ar : $25^{\circ} \mathrm{C}$

Temperatura da água $: 35^{\circ} \mathrm{C}$

$\mathrm{pH}: 7,2$

Eh : $-210 \mathrm{mV}$

Condutividade elétrica: $1520 \mu \mathrm{S} / \mathrm{cm}$

STD : $820 \mathrm{mg} / \mathrm{L}$

Ao que tudo indica parece que se trata de uma surgência natural com vazão de $1 \mathrm{~L} / \mathrm{s}$, ao redor de qual foi construída uma piscina. A água hoje parece completamente parada, cheia de algas e outras plantas. 
O acesso esta quase inexistente no meio de uma vegetação arbustiva com espinhos chamados de marabú.

A surgência está localizada dentro do Arco Vulcânico, nas formações vulcânicas e ígneas intrusivas. As formações Camujiro, cinzas vulcânicas, calcários e lavas, do Cretáceo Superior, e Piragua, cinzas vulcânicas, lavas e pacotes de rochas alcalinas e calcoalcalinas, cobrem o intrusivo, representado por rochas dos complexos granodioríticos e gabro-sieníticos, encontrados nas profundidades de 76,7 m,poço PE-1; 109,8 m, poço PE-2 e $240 \mathrm{~m}$, poço PE-5.

As águas cloretadas sodicas ascendem por pressão entre os contatos litológicos dos anfibolitos e sienitos do Complexo Ígneo através de macrosgretas $(>20 \mathrm{~mm}$ ) associadas ao tectonismo. Os poços PE-3 e PE-5 registraram níveis estáticos acima da superfície do terreno entre $0,51 \mathrm{~m}$ e $0,61 \mathrm{~m}$, e temperatura de $34^{\circ} \mathrm{C}$ (Cascaret et al, 1991).

Infelizmente, o lugar do manancial está totalmente abandonado. Ficaram os restos das antigas instalações balnearias em meio a uma espessa vegetação silvestre. Um dos elementos mais difíceis de superar para reativar a exploração desta fonte é o rio Hatibonico que passa perto da mesma e drena os esgotos da cidade de Camaguey, produzindo um forte e desagradável cheiro no ambiente.

\section{Ponto P-5}

Chaparra, Chaparrita, província de Las Tunas, Cuba.

Data de amostragem : 16.12.98.

Na localidade de Chaparra, em Chaparrita, encontram-se três poços tubulares profundos perfurados para abastecer com água mineral a futura fábrica de engarrafamento de Chaparrita.

Os poços estão numa área rodeada de plantações de cana de açúcar, mas estão cercados por um perímetro de proteção sanitária e protegidos por construções apropriadas.

Foi somente amostrado um dos poços porque os outros dois não apresentavam condições adequadas de coleta de amostras. P-A é o poço amostrado, P-B e $\mathrm{P}-\mathrm{C}$ os não amostrados.

Temperatura do ar: $26^{\circ} \mathrm{C}$

Temperatura da água : $25^{\circ} \mathrm{C}$

$\mathrm{pH}: 7,6$

Eh : $+40 \mathrm{mV}$

Condutividade elétrica: $1800 \mu \mathrm{S} / \mathrm{cm}$ 
Nível estático : $5,2 \mathrm{~m}$.

STD : $1200 \mathrm{mg} / \mathrm{L}$

Alcalinidade:

$\mathrm{HCO}_{3}{ }^{-}=1033,1 \mathrm{mg} / \mathrm{L}$

$\mathrm{CO}_{2}$ livre $=15,4 \mathrm{mg} / \mathrm{L}$

Dados do poço:

O poço amostrado tem $30 \mathrm{~m}$ de profundidade. Como não conseguimos o perfil hidrogeológico deste poço, apresentamos um semelhante, $\mathrm{PH}-3$, perfurado na mesma região (Rodriguez et al, 1990) a seguir :

0-14 m Formação Vazquez (calcários e argilas do Neogêno)

14-27 m Formação Iberia (argilas provenientes da alteração das rochas vulcanógenicas do Cretáceo Superior)

27-80 m Tobas e cinzas vulcânicas alteradas e agretadas da mesma formação anterior.

As águas destes poços estão associadas à circulação através das rachaduras das formações igneas e metamórficas .As águas são bicarbonatadas sódicas, com teor de sólidos totais dissolvidos de $1800 \mathrm{mg} / \mathrm{L}$. Os poços em exploração tem uma vazão de $71,5 \mathrm{~L} / \mathrm{min}(1,2 \mathrm{~L} / \mathrm{s})$.

\section{Ponto P-6}

Peña Azul, província de Camaguey, Cuba.

Data de amostragem : 17.12 .98

Poço tubular profundo que abastece a fábrica de engarrafar água mineral potável de mesa, de Peña Azul, pertencente á cidade de Camaguey.

Nesta fábrica são engarrafadas principalmente botijões de plástico com capacidade de $60 \mathrm{~L}$, tanto para consumo interno como para exportação.

Temperatura do ar: $27^{\circ} \mathrm{C}$

Temperatura da água : $21^{\circ} \mathrm{C}$

$\mathrm{pH}: 6,2$

Eh : $+45 \mathrm{mV}$

Condutividade elétrica: $790 \mu \mathrm{S} / \mathrm{cm}$

Nível estático : 5,2 m.

STD : $500 \mathrm{mg} / \mathrm{L}$

Alcalinidade:

$\mathrm{HCO}_{3}{ }^{-}=125 \mathrm{mg} / \mathrm{L}$ 
A fábrica tem um só poço com uma vazão entre 180 e $240 \mathrm{~L} / \mathrm{min}(4 \mathrm{~L} / \mathrm{s})$. O poço está perfurado na área do Complexo Ofiolítico até os $40 \mathrm{~m}$ onde aparecem os dunitos e peridotitos serpentinizados deste complexo, cuja vazão entre 60 e 240 $\mathrm{L} / \mathrm{min}$ é devida à circulação das águas através das suas fissuras e gretas. Este horizonte freático não tem relação com outros horizontes aqüiferos. As oscilações do nível estático entre $3,6 \mathrm{~m}$ no período úmido e $9,1 \mathrm{~m}$ no período de estiagem, indicam uma relação com a superfície muito direta. As águas são do tipo bicarbonatado magnesiano, características deste meio (Hipolit et al, 1992).

\section{Ponto P-7}

Lesca, (Município de Serra de Cubitas, província de Camaguey, Cuba.

Data de amostragem : 17.12 .98 .

O poço tubular profundo está situado na Serra de Cubitas, ao Norte da cidade de Camaguey.

Temperatura do ar : $27^{\circ} \mathrm{C}$

Temperatura da água : $20^{\circ} \mathrm{C}$

$\mathrm{pH}: 6,5$

Condutividade elétrica: $600 \mu \mathrm{S} / \mathrm{cm}$

STD : $349 \mathrm{mg} / \mathrm{L}$

O poço tem uma profundidade de $60 \mathrm{~m}$ e atravessa só o complexo dos ofiolitos. Nos primeiros metros, encontram-se os eluvios dos serpentinitos e na profundidade os serpentinitos maciços, fortemente agretados e com gretas recheados por carbonatos e magnesitos. O horizonte é freático, segundo o agretamento existente. A vazão é de $108 \mathrm{~L} / \mathrm{min}(1,8 \mathrm{~L} / \mathrm{s})$..

O tipo de água é bicarbonatado magnésico com STD entre 300 e $350 \mathrm{mg} / \mathrm{L}$ e altos teores de sílica, que condicionam uma excelente água mineral natural (Rodriguez, 1994).

A posição deste poço nas elevações poucos habitadas da Serra Cubitas favorece uma alimentação de águas não poluídas, mas também favorece uma mineralização muito direta com as flutuações das chuvas que alimentam este aqüífero.

O poço encontra-se localizado no quintal de uma familia, abastecendo-a, bem como ao restaurante ali instalado. 


\section{RESULTADOS E DISCUSSÃO}

No Capítulo V, Metodologia, foi fundamentada a ordem de avaliação da informação existente para cumprir com o objetivo central da pesquisa: Investigação de associações entre a geologia da área de estudo e os modos de apresentação das águas com vistas de estabelecer analogias úteis às áreas de pouca o nenhuma informação hidrogeológica.

A ordem de avaliação dos resultados compreende:

1. A identificação das correspondências entre o quimismo das rochas e das águas subterrâneas, aplicando comparativamente os diagramas triangulares e gráficos semilogarítmicos para um universo similar de componentes químicos.

2. Classificar os tipos hidroquímicos das águas subterrâneas associados aos conjuntos litológicos pelos quais elas circulam.

3. Estabelecer a correlação da dissociação dos componentes principais com a concentração da solução para cada tipo hidrogeoquímico determinado.

4. Avaliar os limites da estabilidade destas correlações para o prognóstico do comportamento das águas a concentrações acima das águas subterrâneas comuns.

5. Avaliar a regularidade do processo das apresentações dos tipos hidrogeoquímicos no contexto geológico.

6. Relacionar as gêneses das jazidas de águas minerais amostradas com a interpretação hidrogeoquímica regional.

7. Caracterizar as potencialidades regionais dos tipos de águas minerais existentes.

1. Identificação das correspondências entre o quimismo das rochas e as águas subterrâneas, aplicando comparativamente os diagramas triangulares e gráficos semilogarítmicos para um universo similar dos componentes químicos

\subsection{Caracterização química geral das rochas da região de estudo}

Um conjunto de 1263 determinações químicas de rochas da região de estudo, que compreendem a faixa de todos os tipos litológicos existentes, foram utilizados para a análise da relação química geral rocha/água. A Figura 31 apresenta o resultado do processamento do conjunto completo.

No gráfico ternário $A$ pode se apreciar a distribuição percentual dos cátions com tendência ao predomínio relativo de $\mathrm{Ca}$ e $\mathrm{Na}$ (Vide o contorno em vermelho). 

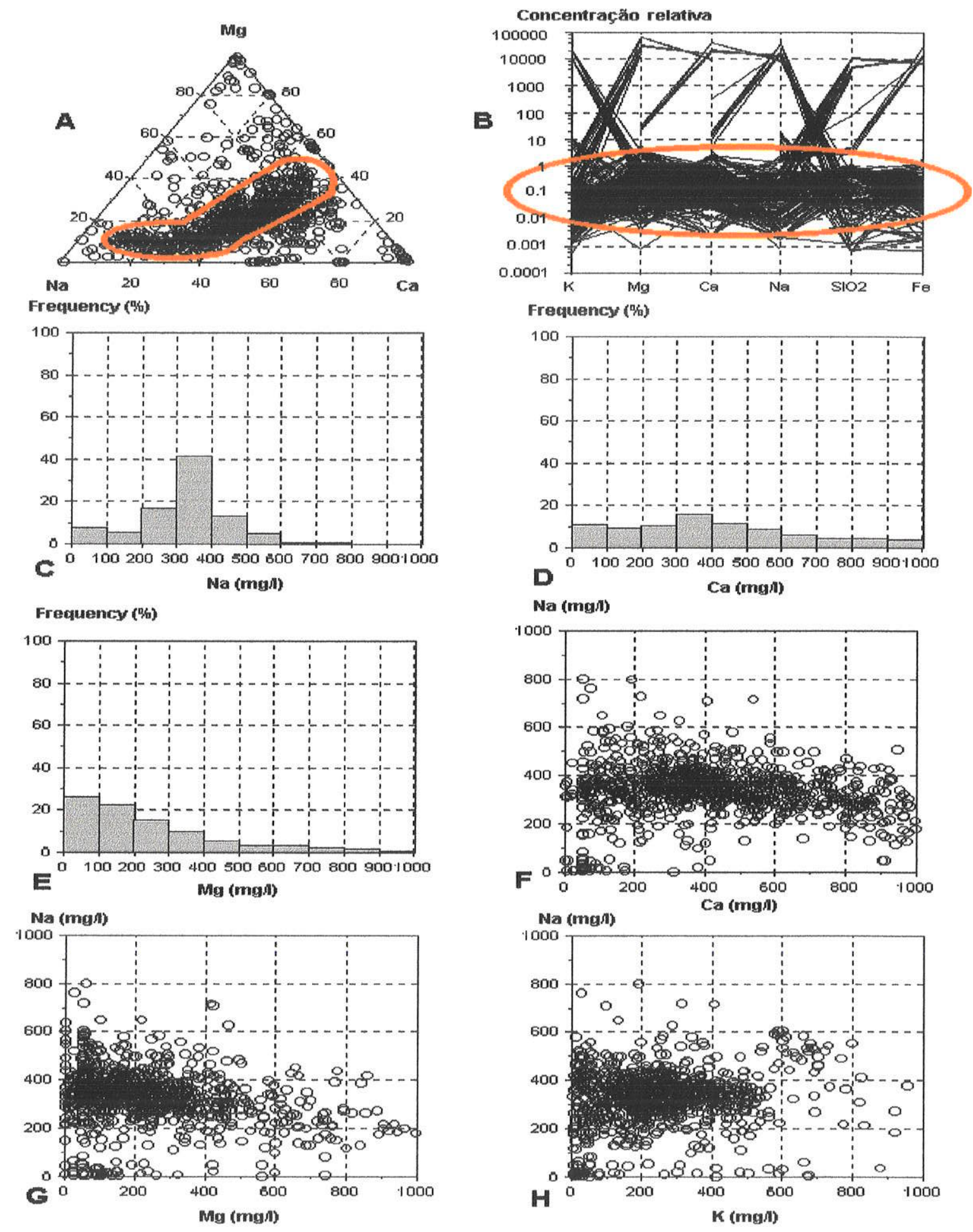

Figura 31. Gráficos apresentando as características gerais da composição química das rochas representadas na região de estudo. (Fonte de dados: Padrón Martín, M.,1998) 
No gráfico semilogarítmico $B$, pode se apreciar uma regularidade das proporções dos componentes $\mathrm{K}, \mathrm{Mg}, \mathrm{Ca}, \mathrm{Na}, \mathrm{SiO}_{2}$ e Fé numa faixa da concentração relativa da composição (determinada pelo peso dos respectivos óxidos) por baixo de $10 \mathrm{e}$ por acima de 0,001, contornada na própria figura por um oval em vermelho. As linhas que excedem o intervalo da referida faixa, representam evidentes valores anômalos, alem de carecer da devida continuidade dos valores grafados.

Os histogramas das figuras $\mathrm{C}, \mathrm{D}$ e $\mathrm{E}$ (Concentrações de $\mathrm{Na}, \mathrm{Ca}$ e $\mathrm{Mg}$, respectivamente) permitem apreciar que, no patamar geral da composição das rochas, a possibilidade da ocorrência de $\mathrm{Na}$ é alta $(40 \%)$ para os valores altos da sua concentração (aparecerá na rocha especifica em altas proporções ou em mínimas concentrações); a possibilidade de ocorrência do Ca é menor do $20 \%$, embora constante para qualquer uma concentração $\mathrm{e}$, o $\mathrm{Mg}$, tem uma possibilidade de ocorrência maior do que $\mathrm{Ca}(25 \%)$ apenas para as concentrações menores existentes nas rochas e quase nula para concentrações maiores. Pode se inferir destes histogramas que os componentes $\mathrm{Na}$ e $\mathrm{Mg}$ serão fundamentais apenas para um entorno litológico limitado a alguns tipos de rochas, como no granito e serpentinita, e que o Ca estará presente em todas as rochas.

As figuras $\mathrm{F}, \mathrm{G}$ e $\mathrm{H}$, que relacionam as concentrações de $\mathrm{Ca}, \mathrm{Mg}$ e $\mathrm{K}$ com as de $\mathrm{Na}$, permitem apreciar que, para o conjunto total litológico, não existem correlações diretas ou inversas entre as concentrações deste conjunto básico de componentes catiônicos analisados. Evidencia-se, também, as possibilidades particulares da coexistência aleatória das concentrações máximas ou mínimas entre estes componentes em algum tipo específico de rocha. Pode se deduzir também que as litologias particulares que se analisarem, devem estar apenas dentro da faixa destas características descritas do conjunto geral, com independência das particularidades das proporções dos componentes que apresentem.

\subsection{Caracterização química específica das rochas e a suas águas subterrâneas}

O patamar geral do quimismo catiônico das rochas existentes na região de estudo e o entorno das possíveis variações, permite analisar as particularidades das relações que possam obter das águas que circulam por cada tipo litológico. $O$ quimismo particular de cada tipo litológico será comparado com o quimismo equivalente das águas subterrâneas reportadas como provenientes da circulação através dessa litologia. A referência principal das comparações rochas/águas será a catiônica, embora em alguns aspetos das respectivas explicações, faça-se alguma referência quanto aos ânions. A função das relações aniônicas é tema de outra parte dos resultados. 


\section{-Serpentinitas e peridotitos (Complexo Ofiolítico)}

A Figura 32 apresenta os gráficos ternários e semilogarítmicos da composição química das rochas, $(A)$, e os gráficos correspondentes de Piper e semilogarítmicos, de Schoeller, (B e C) das águas que circulam pelo mesmo meio.

Pode apreciar-se no diagrama ternário $A$, a proporção majoritária magnésica $e$ calco-magnésica das serpentinitas, podendo se considerar ao $\mathrm{Mg}$ como o componente representativo (CR). No gráfico semilogarítmico é bem manifesta a concentração relativa do magnésio nas águas sobre os demais componentes analisados, onde o $\mathrm{Na}$ e $\mathrm{K}$ distinguem-se pelos seus valores relativos mínimos entre 0.001 e 0.01 . Pode estabelecer-se que a relação das concentrações é $\mathrm{Mg}>\mathrm{Ca}>\mathrm{Na}$, com os valores relativos máximos para o componente representativo principal, $(\mathrm{Mg})$ entre 1-10. $\mathrm{SiO}_{2}$ alcança valores relativos de 1 , enquanto o óxido férrico esta na faixa entre $0,1-1$.

Serpentinitas e peridotitos são os componentes básicos das ofiólitas setentrionais na região de estudo (Vide item 1.21). Do ponto de vista petrográfico, a olivina, silicato magnésio e férrico $(\mathrm{Mg}, \mathrm{Fe})_{2}\left(\mathrm{SiO}_{4}\right)$, é o mineral fundamental da rocha peridotito e a serpentinita é a rocha resultante por metamorfismo sobre o peridotito. A serpentina, silicato magnésico $\left(\mathrm{Mg}_{6}(\mathrm{OH})_{8}\left(\mathrm{Si}_{4} \mathrm{O}_{10}\right)\right.$ é o mineral fundamental da serpentinita associada com outros minerais menos abundantes como granada, augita, horneblenda, talco, etc (Schumann,1974). O processamento dos dados das serpentinitas da região de estudo corresponde com as generalidades destas rochas.

Os esquemas triangulares de Piper e semilogarítmicos de Schoeller do grupo B e $\mathrm{C}$ da figura, processados para as águas que circulam pelos serpentinitas e peridotitos, respectivamente, corroboram o esperado a partir destas rochas: são águas do tipo bicarbonatado magnesiano. Pode se apreciar o predomínio de $\mathrm{Mg}$, em correspondência com as rochas e do $\mathrm{HCO}_{3}$, em correspondência com os resultados do ataque químico do $\mathrm{CO}_{2}$ diluídos nas águas que circulam pelos serpentinitas e peridotitos (Fagundo, 1990).

As figuras $\mathrm{B}$ e $\mathrm{C}$ destacam em vermelho os pontos para os quais as águas provenientes destas rochas tem uma concentração total dos seus componentes dissolvidos em valores acima dos $1000 \mu \mathrm{S} / \mathrm{cm}$ da condutividade, ou aproximadamente igual a $1000 \mathrm{mg} / \mathrm{L}$ de Sólidos Totais Dissolvidos (STD). Ainda que a anterior igualdade não seja exatamente similar, a prática comum assim iguala ambos os parâmetros para fins de associar a comparação dos seus valores. A manifesta correspondência verificada permite destacar que as águas bicarbonatadas magnesianas $\left[\mathrm{Mg}\left(\mathrm{HCO}_{3}\right)\right]$ podem ter também uma concentração superior aos $1000 \mathrm{mg} / \mathrm{L}$ de STD, o que acrescenta mais um pouco ao limite existente ate o presente, em volta dos $300 \mathrm{mg} / \mathrm{L}$ de STD, para as águas das rochas ígneas, generalizado na literatura especializada (Matthess, 1982; 

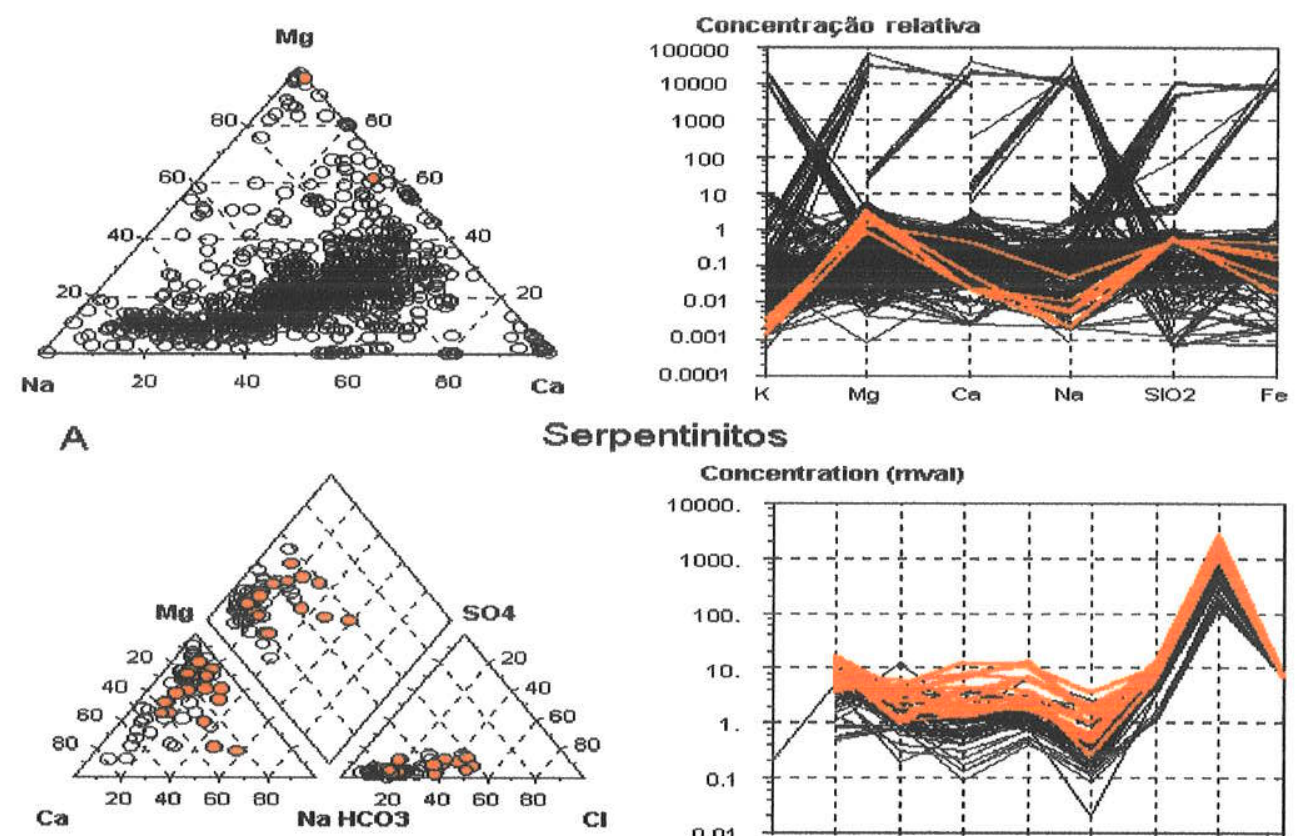

Serpentinitos

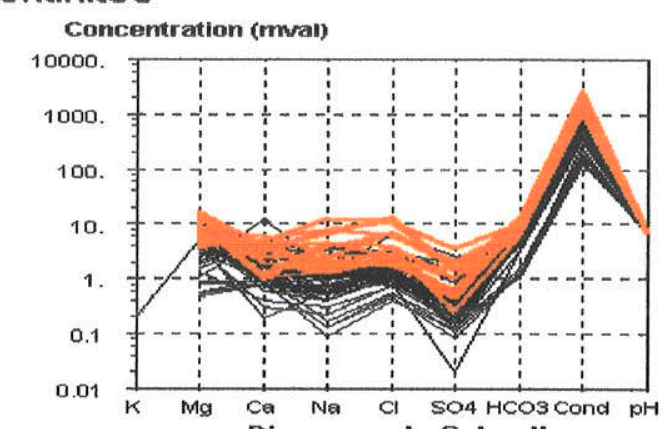

$\mathrm{B}$

Aguas dos serpentinitos Diagrama de Schoeller
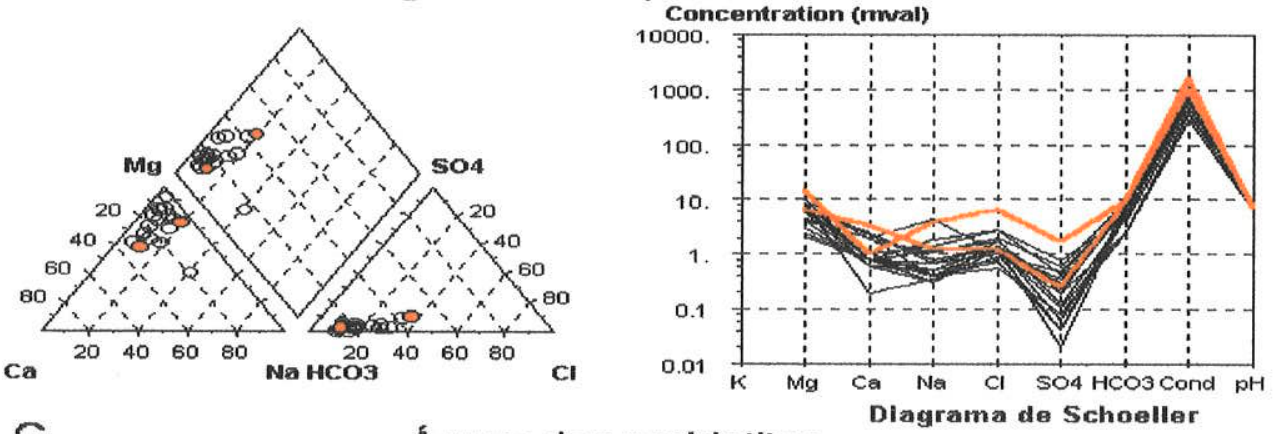

$\mathrm{C}$

Águas dos peridotitos

Legenda:

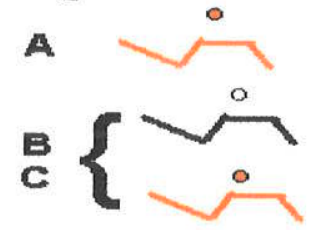

Pontos representativos do tipo litológico sob análise dentro do campo total do quimismos das rochas da regiäo de estudo Análises representativos das águas subterrâneas que circulam nas litologias em referencia

Idem para as condiçóes de : Condutividade $>1000 \mu \mathrm{S} / \mathrm{cm}$

I.S. $\mathrm{HCO} 3<0$

Figura 32. Gráficos que comparam a composição química das rochas origem $e$ as águas subterrâneas que circulam pelos serpentinitos e peridotitos de Camaguey.

(Fonte de dados: Rodriguez, F., 1996 e Pdrón Martín, M.,1998) 
Schoeller,1962; Szikszay ,1993). Os Índices de Saturação (I.S.) menor de zero (agressivo) para o bicarbonato nas concentrações superiores aos $1000 \mathrm{mg} / \mathrm{L}$ de STD, mantendo a composição bicarbonatada magnesiana, parecem indicar o poder de dissolução apesar de sua maior concentração. Para o grau de informação ate aqui alcançado, pode se inferir que a ação agressiva do $\mathrm{CO}_{2}$ é mais intenso ou chega mais profundo nas condições ambientais, tropicais, da região de estudo. O clima tropical úmido, com a influencia direta do mar devido a sua condição insular, pode tornar mais enérgica a atividade do $\mathrm{CO}_{2}$ à mesma profundidade, ou alcançar maiores profundidades à mesma intensidade do que para as condições continentais. Contribui argumentar mais um pouco a ocorrência destas possibilidades, as diferenças evidenciadas entre os resultados ambientais da ação dos processos cársticos no continente e no meio insular tropical (Fagundo et al, 1996). Como o sentido da interpretação deste capítulo é abordar as correspondências rochas/águas mediante as comparações dos tipos químicos e suas proporções relativas entre si, os aspectos relacionados com os processos e comportamentos dos componentes dissolvidos nas águas é objetivo do próximo capítulo

\section{-Rochas ígneas intrusivas (granitos, dioritos e granodioritos)}

A Figura 33 apresenta os resultados dos processamentos atraves dos diagramas ternários e semilogarítmicos dos granitos $(A)$, granodioritos $(B)$ e dioritos $(C)$. No presente caso, não relacionam-se com as águas para apreciar as diferenças $\mathrm{e}$ similariedades entre eles e assim poder conceber melhor a interpretação quando sejam relacionadas com suas águas.

$\mathrm{Na}$ figura podemos notar a alta proporção que os granitos tem de $\mathrm{Na}$, permitindo considerar este cátion como seu componente representativo (CR), assim como seu valor relativo mais alto $(0,1-1)$, superado apenas pelo $\mathrm{SiO}_{2}(1)$. A relação das suas concentrações é: $\mathrm{Na}>\mathrm{Ca}=\mathrm{Mg}$.

Os granodioritos tem como componente representativo o Ca no gráfico ternário (ainda que pode se considerar como uma representatividade compartida junto ao $\mathrm{Mg} \mathrm{e} \mathrm{Na).} \mathrm{Apreciam-se} \mathrm{concentrações} \mathrm{relativas} \mathrm{similares} \mathrm{entre} \mathrm{estes} \mathrm{cátions} \mathrm{(0,1-}$ 1) superados também apenas pelo $\mathrm{SiO}_{2}(1)$. A relação das suas concentrações é : $\mathrm{Ca}=\mathrm{Mg}=\mathrm{Na}$.

Os dioritos tem também como componente representativo o Ca no gráfico ternário, mas nota-se que os valores relativos são similares ao do $\mathrm{Mg}(0,1-1)$, superados também apenas pelo $\mathrm{SiO}_{2}(1)$. $\mathrm{O} \mathrm{Na}$ diminui para $<0,1$. A relação das suas concentrações é: $\mathrm{Ca}=\mathrm{Mg}>\mathrm{Na}$.

A diferença entre o granito e o diorito deve-se a que o primeiro tem quantidades maiores de feldspato sódico-cálcico, feldspato potássico e quartzo (minerais claros) em relação ao segundo (Schumann, 1974). O granodiorito é uma rocha de transição entre ambos. 

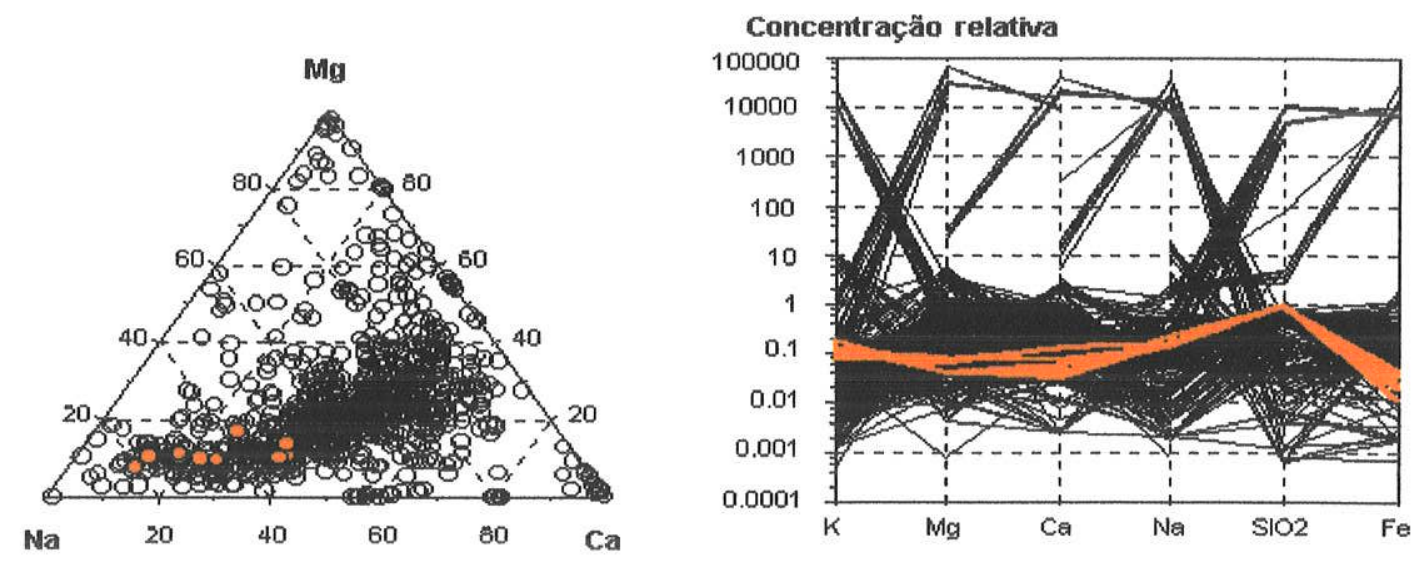

A

\section{Granitos}
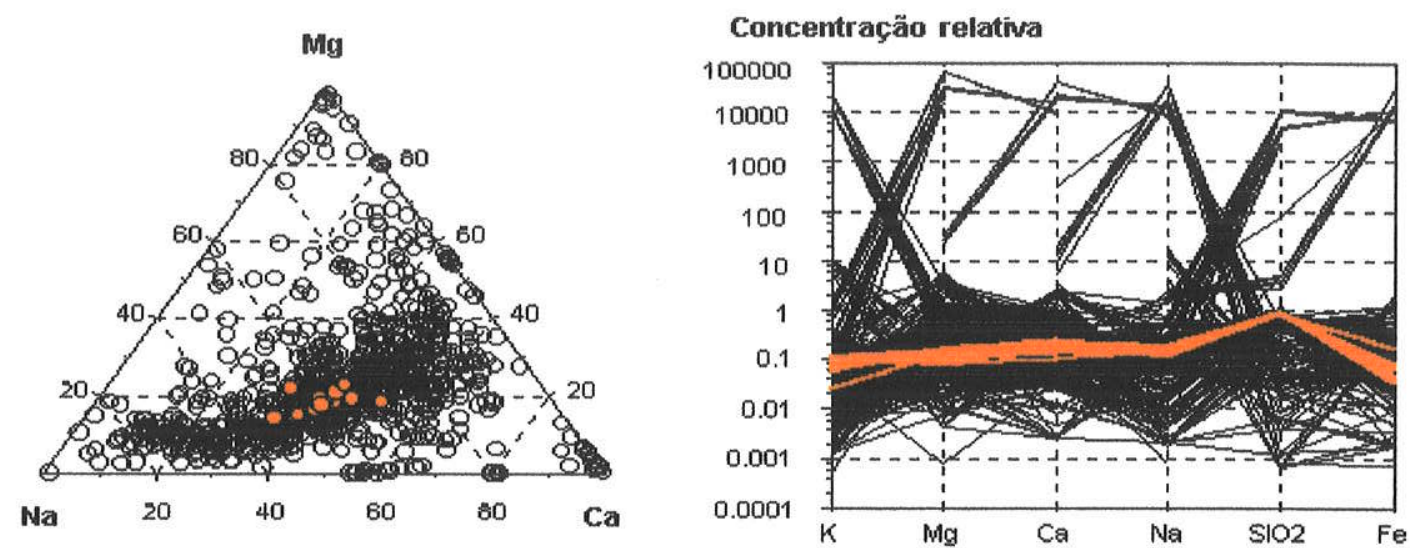

$\mathbf{B}$

\section{Granodioritos}

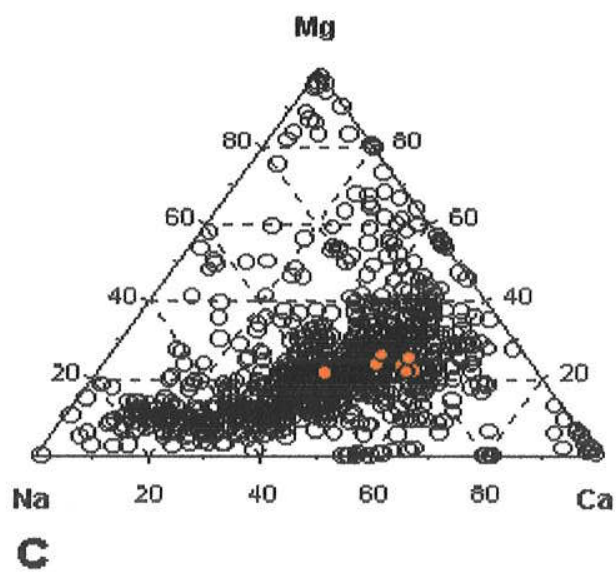

Concentração relativa

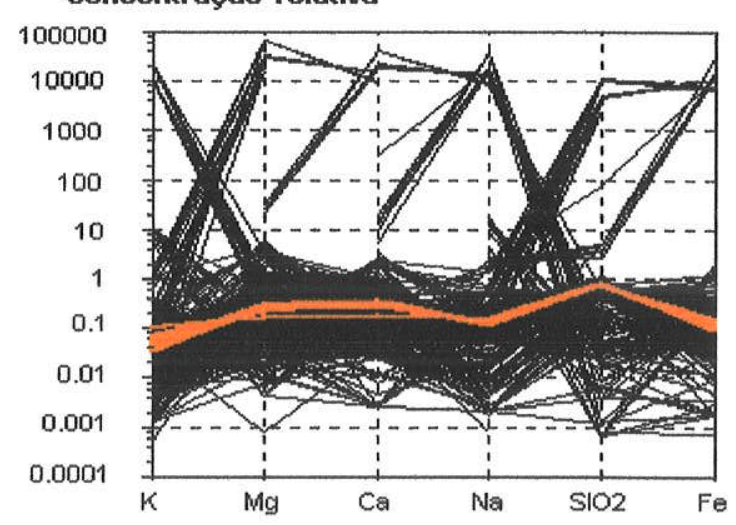

Dioritos

\section{Legenda :}

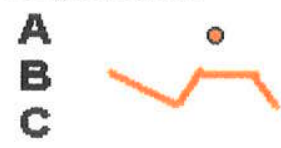

Pontos representativos do tipo litológico sob análise dentro do campo total do quimismos das rochas da região de estudo

Figura 33. Gráficos relacionados com as características da composição química das rochas ígneas intrusivas representadas na região de estudo.

(Fonte de dados: Padrón Martín, M.,1998) 
Os diagramas apresentados organizaram-se nessa ordem para constatar a posição intermédiaria do granodiorito, analisado pelos diagramas ternários, como semilogarítmicos, o que permite conferir a certeza do processamento e a qualidade da representatividade dos dados das determinações químicas utilizadas.

\section{-Granitos de Camaguey}

O processamento das águas subterrâneas provenientes da circulação nos granitos de Camaguey, apresentam-se na Figura 34 , junto aos diagramas do granito, já analisado, com o fim de uma melhor compreensão das interpretações.

Nota-se correspondência quanto a presencia abundante do $\mathrm{Na}$, com forte tendência ao incremento do $\mathrm{Ca}$, num ambiente aniónico do predomínio do $\mathrm{HCO}_{3}$. Podem caracterizar-se como águas bicarbonatadas sódicas, com presencia do $\mathrm{Ca}$. Tanto o $\mathrm{Na}$ como o $\mathrm{Ca}$ estão justificados devido à erosão dos minerais feldspatos sódicos-cálcicos, não assim sendo o Mg, que foi componente justificado dos peridotitos e serpentinitas.

Cabe destacar que a rocha sob análise, o granito de Camaguey, não é um bloco monolítico homogêneo nem extenso em superfície, senão um corpo ígneo irregular e heterogêneo constituído de granitos, dioritos e demais proporções minerais da diferenciação magmática, que aflora em áreas dispersas. Este destaque para o granito permite considerar a possibilidade que as águas reportadas para esta litologia podem corresponder também com granodioritos ou dioritos, segundo a abundância local do ponto, mas nunca fora da faixa química esperada. O fato de conseguir uma boa correspondência das águas com esta rocha sob estas condições péssimas da continuidade do maciço, ratifica a representatividade certa da informação processada (Vide Capítulo V, Metodologia)

Pode ser visto na figura analisada que também se repete a composição bicarbonatada sódica, mantendo-se mesmo com a concentração de STD aumentada para valores superiores de $1000 \mathrm{mg} / \mathrm{L}$. Em semelhança com as águas das serpentinitas e peridotitos, existem águas da composição proveniente do granito com mineralização superior à referida na literatura especializada, e, com valores dos Índices de Saturação que as caracterizam como incrustantes. A diferença do evidenciado nas águas das serpentinitas, aqui se faz visível nos gráficos de Piper e Schoeller, uma transformação aparentemente gradual ao tipo cloretado sódico.

\section{-Granodioritos de Las Tunas e Camaguey}

Mesmo que no caso anterior, o processamento das águas subterrâneas provenientes da circulação nos granodioritos das províncias de Camaguey e Las Tunas, são mostrados na Figura 35 , junto aos diagramas do granodiorito, já analisado, com a finalidade de uma melhor compreensão das interpretações. 

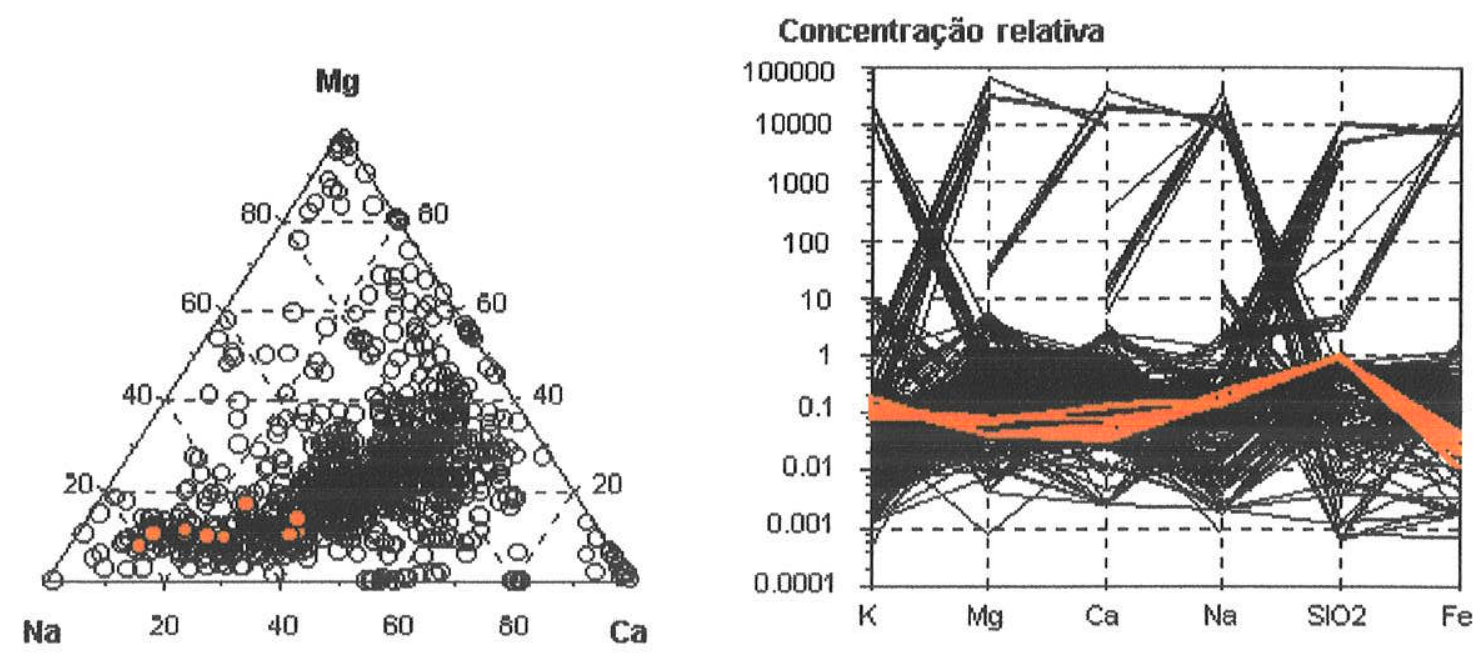

A

\section{Granitos}
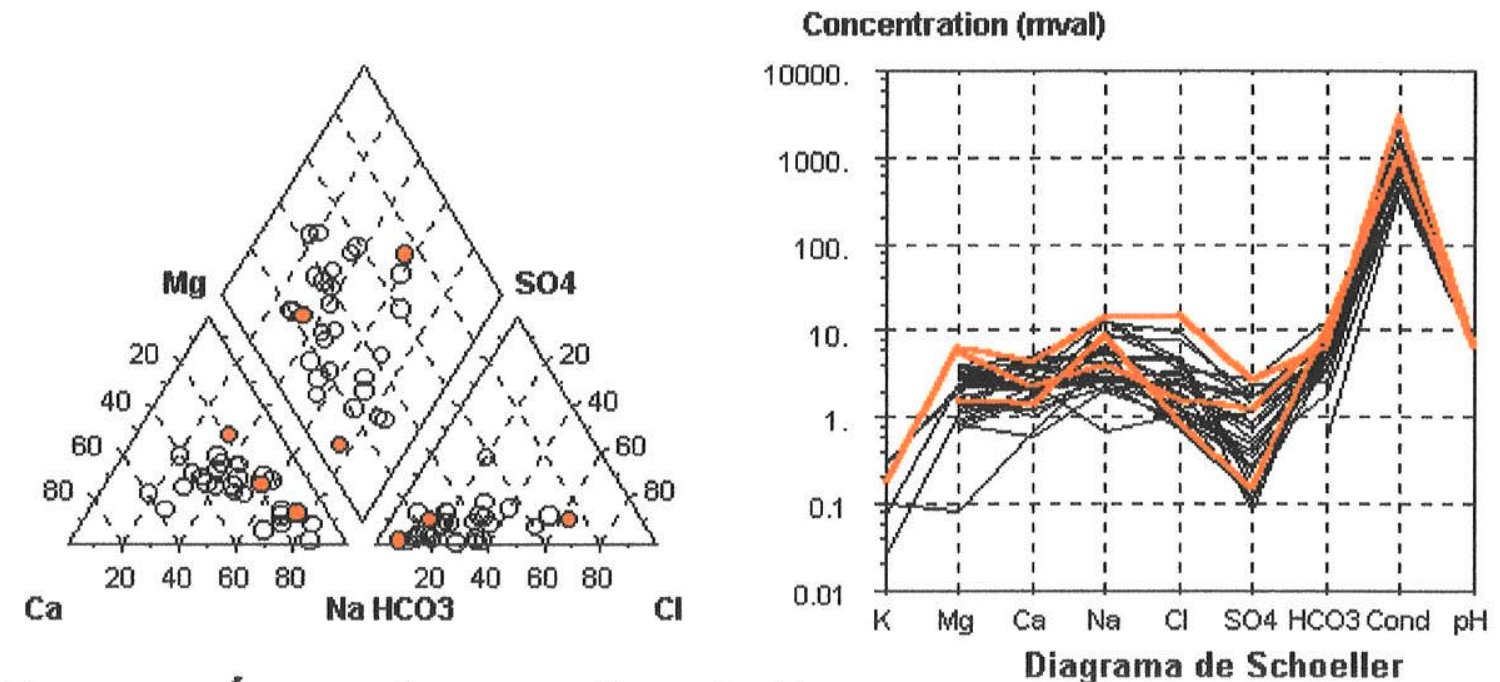

\section{B Águas dos granitos de Camaguey}

\section{Legenda :}

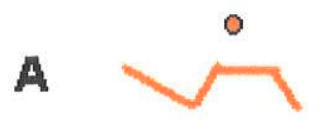

Pontos representativos do tipo litológico sob análise dentro do campo total do quimismos das rochas da região de estudo

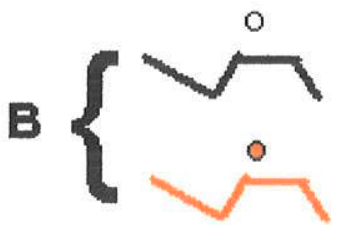
Análises representativos das águas subterrâneas que circulam nas litologias em referência Idem para as condições de :

Condutividade $>1000 \mu$ Sicm I.S. $\mathrm{HCO} 3>1$ I.S. $\mathrm{H} 4 \mathrm{SiO} 4>1$

Figura 34. Gráficos que comparam a composição química das rochas origem e das águas subterrâneas que circulam pelos granitos de Camaguey.

(Fonte de dados: Rodriguez, 1996 e Padrón Martín, 1998) 
Nota-se no diagrama de Piper que as águas subterrâneas que circulam nos granodioritos são bicarbonatadas sódicas cálcicas, podendo o Mg existir em proporções consideráveis, correspondentes com as possibilidades locais da entrega catiônica dos granodioritos. Neste caso particular, a correspondência rocha/água é avaliada através dos mesmos resultados para águas reportadas da mesma litologia em duas províncias diferentes, devido a que o corpo dos granodioritos estende-se longitudinalmente de uma província à outra por mais de $200 \mathrm{~km}$ na direção NE-SO, com contínuos afloramentos em Las Tunas e dispersos em Camaguey. Estes fatos apóiam mais a representatividade certa alcançada para a informação processada.

Reconhecem-se para os granodioritos varias unidades litoestratigráficas, cujo quimismo do conjunto é calcoalcalino, com tendência alcalina que varia desde potássica na base ate sódica na parte superior (Iturralde-Vinent, 1994). O enriquecimento de $\mathrm{K}$ nas águas podia dar elementos sobre a procedência inferior ou superior do maciço granodiorítico, mas, lamentavelmente, devido às irregularidades dos relatórios dos laboratórios de análise, que poucas vezes especificam os diferentes teores de $\mathrm{K} \mathrm{e} \mathrm{Na}$, determinando, as vezes como $\mathrm{K}+\mathrm{Na}$ e outras apenas como $\mathrm{Na}$, não considerou-se o processamento específico dos teores de $\mathrm{K}$ nas águas.

Destaca-se que enquanto nas águas bicarbonatadas sódicas cálcicas dos granodioritos de Camaguey tem algumas com valores dos STD $>1000 \mathrm{mg} / \mathrm{L}$ e também incrustantes, como as águas dos serpentinitos e granitos, as águas bicarbonatadas sódicas cálcicas dos granodioritos de Las Tunas com TDS $>1000$ $\mathrm{mg} / \mathrm{L}$ são as mais abundantes e, com o Índice de Saturação $<0$ para o $\mathrm{HCO}_{3}$, incrustante, em apenas uma amostra entre as processadas, o que significa, contrario aos casos anteriores, onde a maioria destas águas dos granodioritos de Las Tunas são sub saturadas com respeito ao bicarbonato e agressivas.

Mais uma vez, tem-se águas provenientes de rochas ígneas cujas salinidades são maiores que as referidas na literatura especializada e repete-se, com as mesmas condicionalidades dos casos precedentes, a tendência à presencia das águas do tipo cloretado sódico coexistindo com as bicarbonatadas.

\section{-Basaltos, lavas e tufos}

No caso das rochas extrusivas que formam parte do Arco Vulcânico do Cretáceo também se procedeu a seu processamento específico para os basaltos, lavas e tufos com o mesmo fim comparativo quanto às águas. A particularidade destea análise baseia-se em que na região de estudo, nem no resto de Cuba, existem águas que circulam individualmente através de um ou outro destes meios indicados. O resultado da evolução geológica configurou diferentes formações geológicas, como Contramaestre e Caobillas, constituídas principalmente por alternações de basaltos, lavas e tufos junto a outros produtos sedimentares dos pequenos períodos de descansos da atividade magmática até o seu fim, no começo do Cenozóico. 

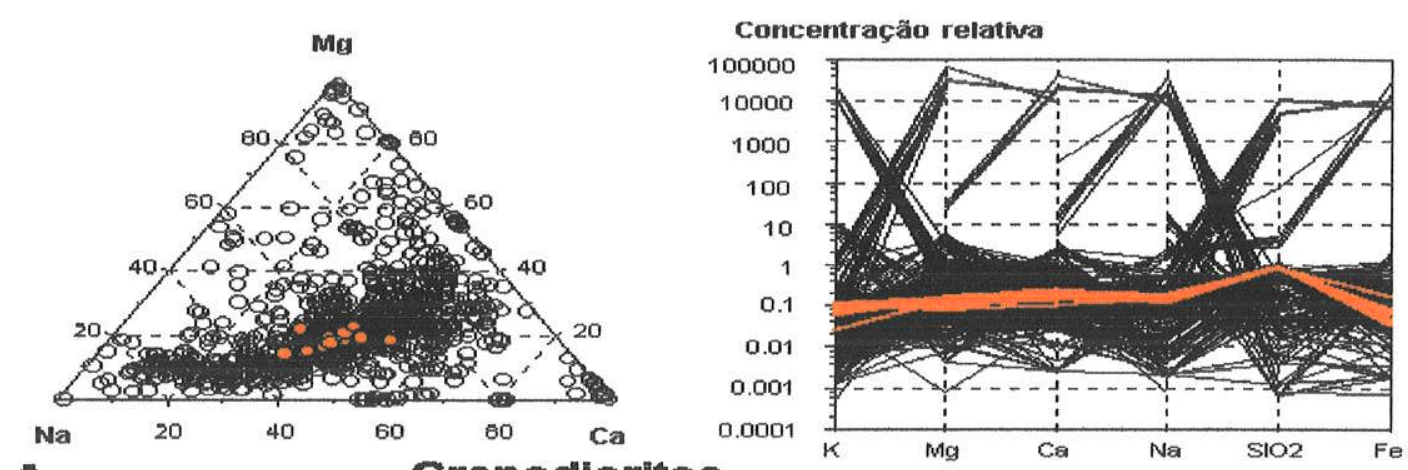

A Granodioritos
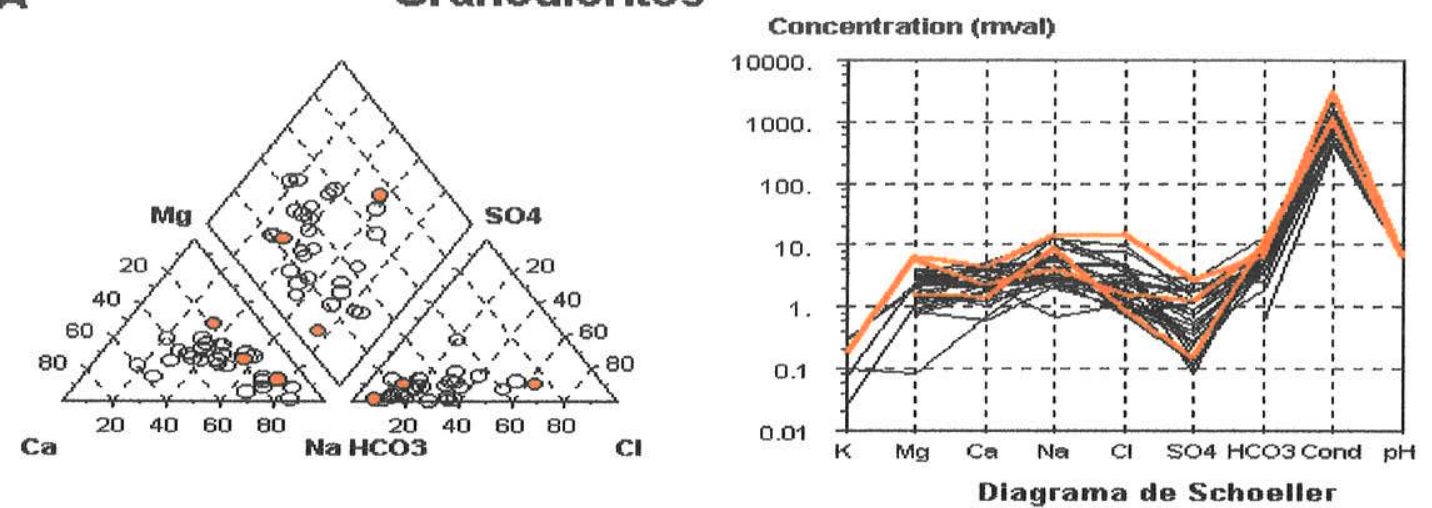

B Águas dos granodioritos de Camaguey
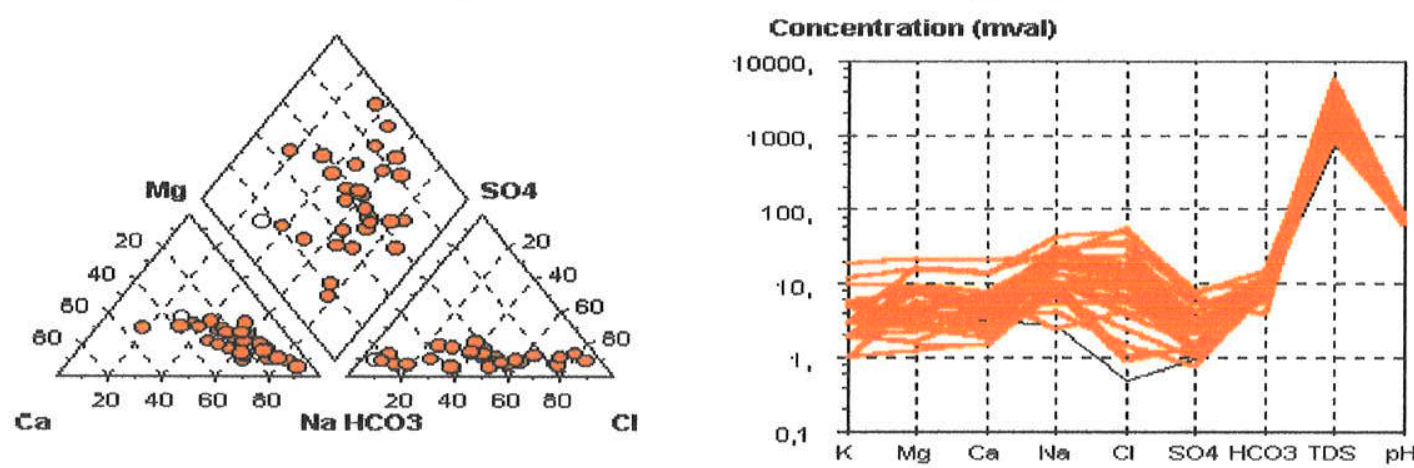

C Águas dos granodioritos de Las Tunas

Legenda:

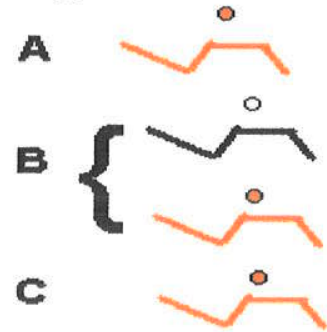
Pontos representativos do tipo litológico sob análise dentro do campo total do quimismos das rochas da regiäo de estudo
Análises representativos das águas subterrâneas que eirculam nas litologias em referẻncla

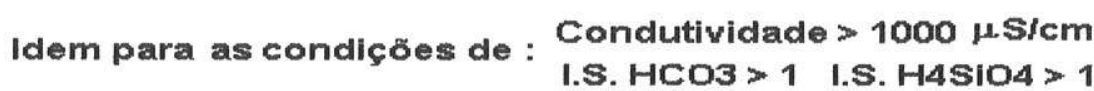
Idem para as condiçöes de : Condutividade $>1000 \mu$ Sicm
I.S. $\mathrm{HCO} 3<0$

Figura 35. Gráficos que comparam a composição química das rochas origem e das águas subterrâneas que circulam pelos granodioritos de Camaguey e Las Tunas

(Fonte de dados: Rodriguez, 1996 e Padrón Martín, 1998) 
Figura 36 apresenta similares processamentos às litologias anteriores para os basaltos (A), lavas (B) e tufos (C). Pode se apreciar o Mg como componente representativo dos basaltos e lavas com um valor relativo entre $0,1-1$ e o valor mínimo de $\mathrm{Na}(0,01-0,1)$. $\mathrm{A} \mathrm{SiO}_{2}$, referido na literatura especializada, não é um valor superior quanto aos intrusivos (0.1-1). A relação de concentração para estes dois tipos de rochas é $\mathrm{Mg}>\mathrm{Ca}>\mathrm{Na}$.

Os tufos têm o Ca como componente principal, com valores relativos entre 0,1-1, enquanto o Na mantém-se como valor mínimo relativo em volta de 0,1 . A relação de concentrações relativas é: $\mathrm{Ca}>\mathrm{Mg}>\mathrm{Na}$. O resultado permite supor que as águas com o Mg predominante sobre o Ca poderão implicar uma circulação preferencial ou maioritariamente através dos basaltos e lavas. No caso contrario, se o $\mathrm{Ca}$ predomina, significaria a circulação através dos tufos. O Na não é o componente representativo, mas a sua presença é significativa, podendo ser esperado nas águas, sob determinada probabilidade, predomínio do $\mathrm{Na}$ sobre $\mathrm{Ca}$ ou Mg.

As observações e suposições anteriores são coerentes para a circulação das águas subterrâneas se as mencionadas litologias vulcânicas constituíssem grandes corpos homogêneos e nitidamente diferenciados, que não é o caso em análise. Estas rochas são componentes das formações geológicas Contramaestre e Caobillas, em combinação com outras deposições sedimentáres, podendo-se esperar qualquer uma combinação, segundo o predomínio da rocha presente.

\section{-Formações geológicas Contramaestre e Caobillas}

A Figura 37 apresenta os resultados dos processamentos para as águas subterrâneas que circulam pelas formações geológicas Contramaestre (B) e Caobillas (C), com a base litológicas comparativa dos tufos (A).

O fato de comparar as citadas formações geológicas com os tufos é totalmente aleatório por enquanto não se espera fidelidade nenhuma com um ou outro tipo litológico devido a que as águas processadas respondem à circulação através desses diferentes tipos de rochas e não a um tipo único. A representatividade e fidelidade demonstrada com os casos das litologias homogêneas permite agora confiar nas representatividades particulares dos resultados para estes casos heterogêneos.

Por isso, pode se interpretar que as águas provenientes da formação Contramaestre são, principalmente, bicarbonatadas cálcicas sódicas, mas, como para a maioria dos casos anteriores, incrustantes para TDS $>1000 \mathrm{mg} / \mathrm{L} \mathrm{e}$, também, que seus valores das concentrações são maiores que os reportados na literatura especializada para as águas provenientes das formações vulcânicas. As águas da formação Caobillas apresentam o predomínio das águas do tipo cloretado sódico sobre o bicarbonatado sódico cálcico, com a particularidade de ter a maior parte das suas águas com seus TDS $>1000 \mathrm{mg} / \mathrm{L}$ e serem agressivas com respeito ao bicarbonato e silicatos (I.S. $\mathrm{HCO}_{3}$ e $\mathrm{H}_{4} \mathrm{SiO}_{4}<1$ ). 

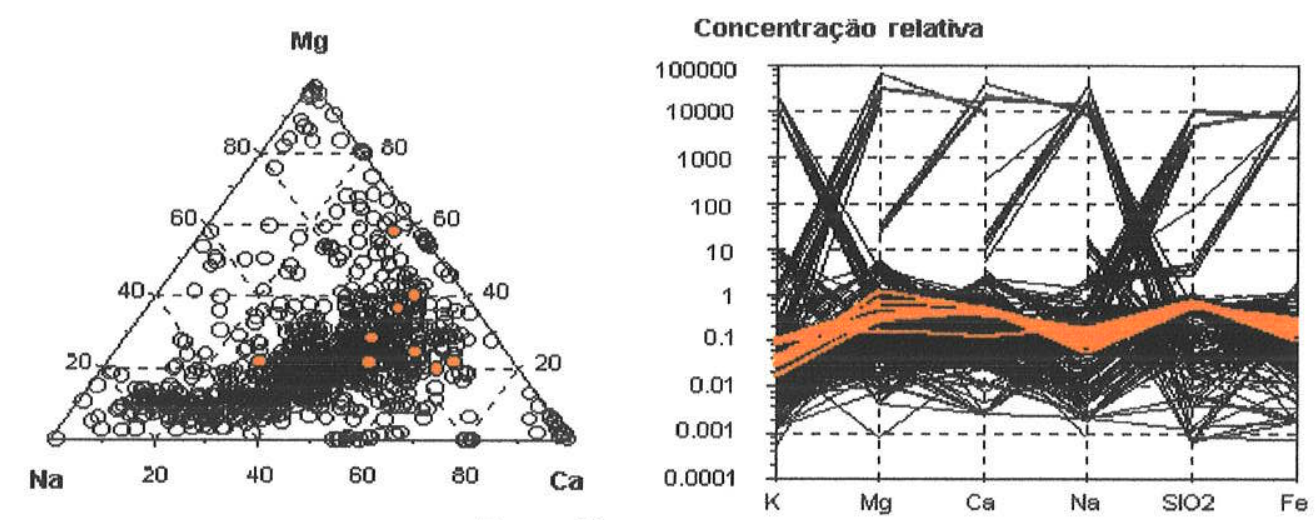

A

Basaltos
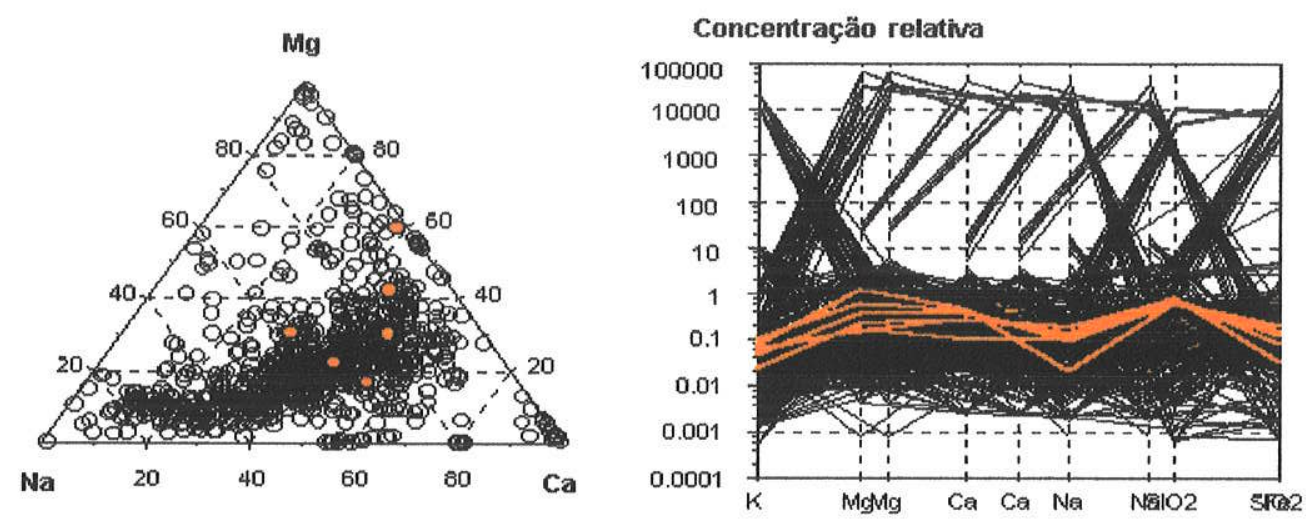

$\mathbf{B}$

\section{Lavas}
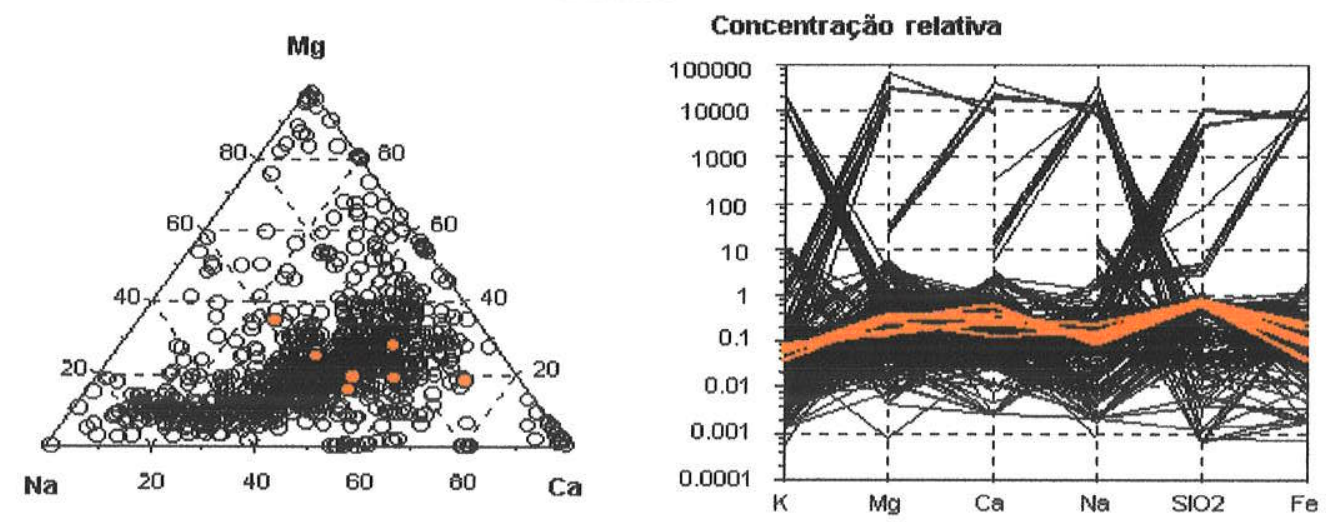

C

Tufos

Legenda :

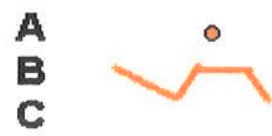

Pontos representativos do tipo litológico sob análise dentro do campo total do quimismos das rochas da região de estudo

Figura 36. Gráficos relacionados com as características da composição química das rochas vulcânicas representadas na região de estudo.

(Fonte de dados: Padrón Martín, 1998) 

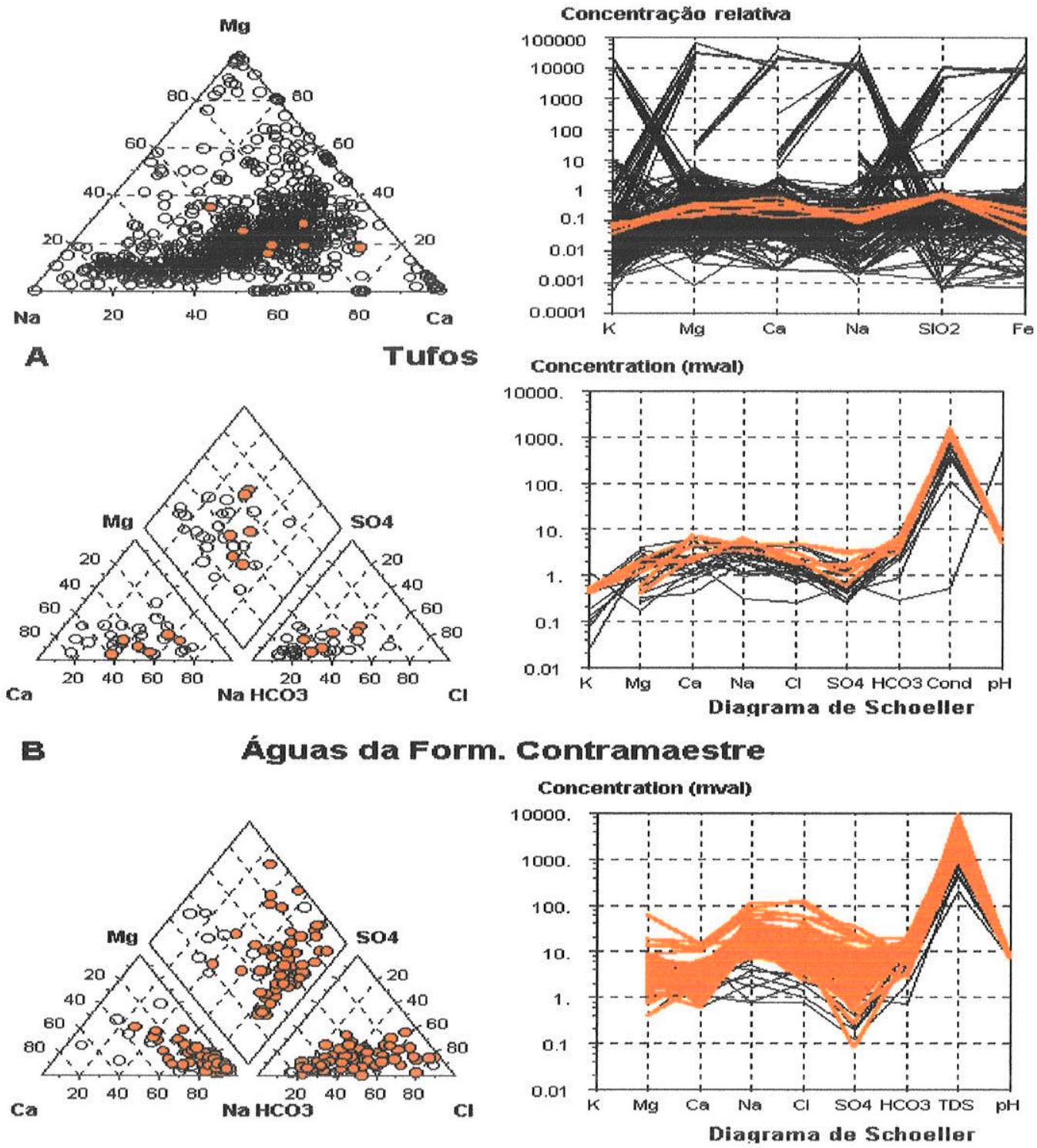

C

Aguas da Form. Caobillas

Legenda :

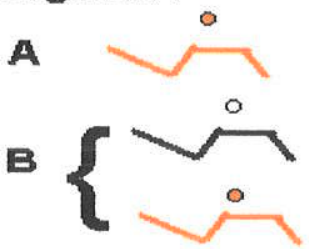
Pontos representativos do tipo litológico sob análise dentro do campo total do quimismos das rochas da regiäo de estudo
Análises representativos das águas subterrâneas que circulam nas litologias em referência
Idem para as condições de : Condutividade > $1000 \mu$ Sicm I.S. $\mathrm{HCO}>1$ I.S. $\mathrm{H} 4 \mathrm{SiO} 4>1$
C

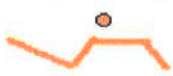
Idem para as condiçöes de : Condutividade $>1000 \mu$ Sicm I.S. $\mathrm{HCO}<1$ I.S. $\mathrm{H} 4 \mathrm{SIO} 4<1$

Figura 37. Gráficos que comparam a composição química das rochas origem e das águas subterrâneas que circulam pelas formações geológicas Contramaestre e Caobillas

(Fonte de dados: Rodriguez, 1996 e Padrón Martín, 1998) 
O outro caso similar é o resultado das águas nos granodioritos de Las Tunas. Nos dois casos evidencia-se uma transformação gradual das águas bicarbonatadas há águas cloretadas. Coexistem ambos tipos de águas dentro as suas respectivas litologias de procedência.

As indicações sobre assegurar a qualidade da procedência dos dados utilizados obedecem a não duvidar nem descriminar estes resultados pelo seu desvio dos demais resultados e procurar uma interpretação conseqüente e concatenante com a sua respectiva e possivel explicação. É de sumo interesse que os resultados dos processamentos das águas dos granodioritos de Las Tunas e da Formação Caobillas tenham particularidades similares.

\section{-Rochas calcárias}

A Figura 38 apresenta o processamento para as rochas calcárias da região de estudo (A) e suas representações para as águas que circulam na Formação Guines de Ciego de Avila (B) e a Formação dos calcários de Camaguey (C).

Nos gráficos ternários e semilogarítmicos da figura $A$ evidencia-se claramente o caráter carbonatado cálcico da composição química deste conjunto litológico, onde o componente representativo é o $\mathrm{Ca}(1-10)$ e o $\mathrm{Na}$, o componente de mínima concentração relativa $(0,001-0,01)$. A concentração relativa do $\mathrm{SiO}_{2}$ é reduzida $(0,1)$. A relação das concentrações é $\mathrm{Ca}>>\mathrm{Mg}>\mathrm{Na}$, que corresponde com os dados da literatura especializada a literatura especializada para estas rochas.

As formações sob análise pertencem à Cobertura Cenozóica (Vide item IV $2.1 \mathrm{e}$ 2.2). As águas que circulam por elas $(B$ e $C$ ) representam fielmente o caráter carbonatado cálcico que originam estas rochas, nas quais aprecia-se que parte destes tipos tem os STD $>1000 \mathrm{mg} / \mathrm{L}$ e no caso específico da formação carbonatada de Guines de Ciego de Avila, algumas são do tipo cloretado sódico. Aqui não existem diferenças com o explicado na literatura especializada, muito extensa devido a que este meio carbonatado representa uns dos aqüiferos mais poderosos do mundo e as suas características particulares originam o bem conhecido karste. Em Cuba, como na região de estudo em particular, os aqüiferos kársticos, representados principalmente pela Formação Guines, que se estende até o ocidente do pais (província de Pinar del Rio), alcançando ambas as costas do pais (Vide Figuras 7, 8, 9, 10 e 11), permite a manifestação do processo de intrusão marinha, sendo comum a existência das águas cloretadas sódicas nesta formação calcária, e também, as possibilidades da existência de valores de STD > $1000 \mathrm{mg} / \mathrm{L}$, se evidentemente relacionadas com o mar. 

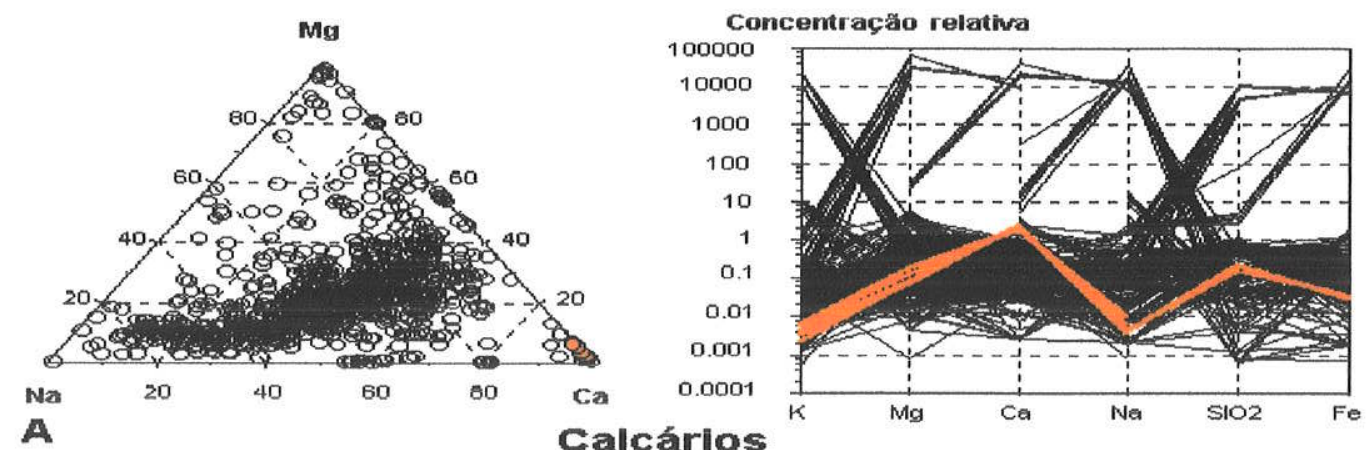

Calcáríos
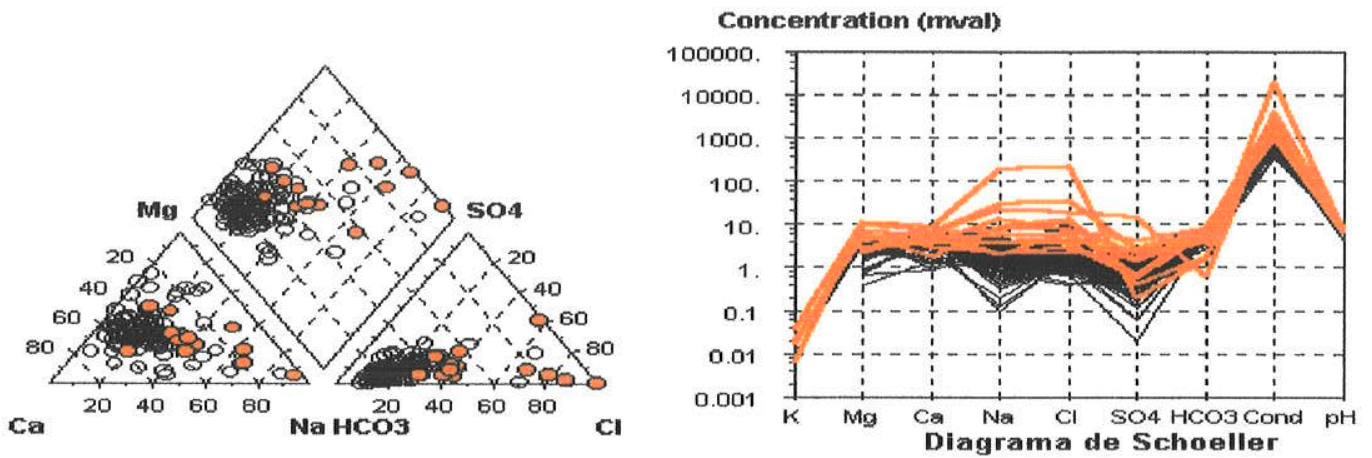

$\mathbf{B}$

Form. Guines de Ciego de Ávilla
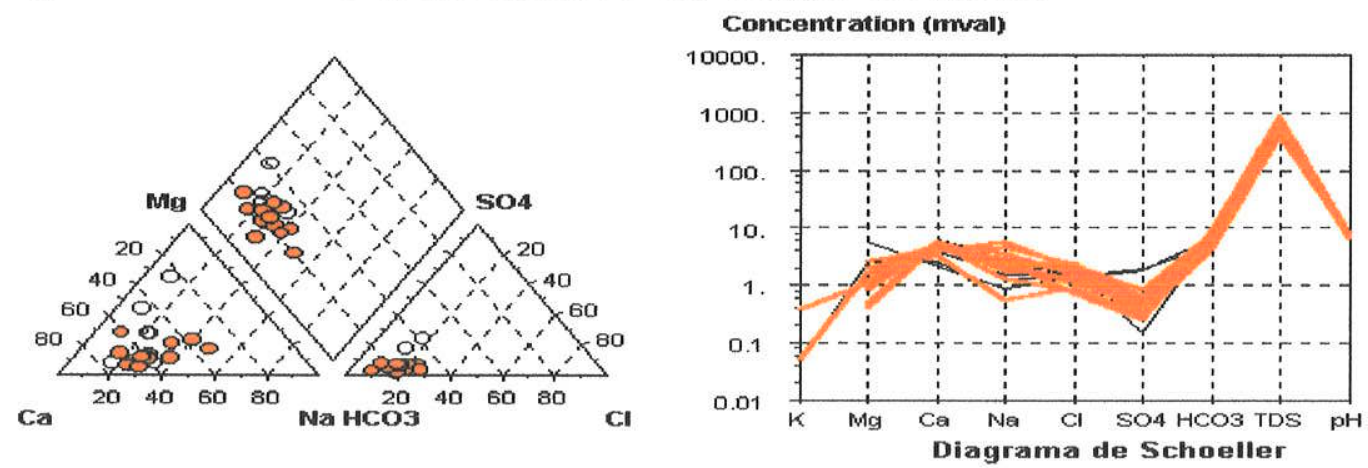

c.

Form. de calcários de camaguey

Legenda:

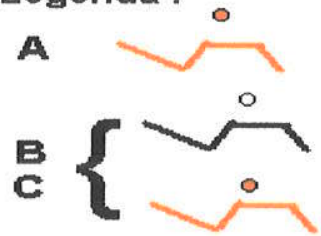

Pontos representativos do tipo litológico sob análise dentro do campo total do quimismos das rochas da regiäo de estudo

Analises representativos das aguas subterraneas que circulam nas litologias em referência

Idem para as condiçöes de : Condutividade $>1000 \mu \mathrm{s} / \mathrm{cm}$

Figura 38. Gráficos que comparam a composição química das rochas origem e das águas subterrâneas que circulam pela Formação Guines de Ciego de Avila e os calcários de Camaguey

(Fonte de dados: Rodriguez, 1996 e Padrón Martín, 1998) 


\section{-Rochas argilosas}

A Figura 39 apresenta o resultado do processamento para o grupo selecionado das rochas argilosas $(A)$ e das águas circulando por formações geológicas com abundante composição deste material sedimentar, a Formação Vertientes (B) e a Formação Vila Roja (C).

Pode reconhecer-se na composição química destas rochas o $\mathrm{Mg}$ como o componente principal (1-10), que para uma parte do grupo concorrem com o $\mathrm{Ca}$, e por enquanto, o $\mathrm{Na}$ mantém-se nos valores mais baixos $(0,001-0,01)$. A relação das concentrações relativas é: $\mathrm{Mg}>\mathrm{Ca}>\mathrm{Na}$.

Pouco se pode argumentar em relação a estes resultados, devido à reconhecida heterogeneidade do quimismo da composição argilosa proveniente das variedades possíveis dos minerais argilosos existentes. Uma correspondência melhor seria expressar o quimismo através da sua composição mineralógica em lugar da petrográfica efetuada, que, como foi explicado, não existe na informação primária.

A literatura especializada atribui às águas subterrâneas provenientes destes meios argilosos uma alta variabilidade na sua composição química, considerando a possibilidade geral de conter sulfatos e cloretos. Tais casos são justificados pela presencia dos minerais de pirita e pela concentração das águas marinhas aprisionadas em períodos geológicos antecedentes (Drever, 1985).

As formações escolhidas foram Vertientes, do Paleógeno, e Vila Roja, do Quaternário, ambas as duas com uma proporção notável dos componentes argilosos (Vide item IV 2.1 e 2.3). A primeira ocupando partes centrais da região de estudo, quase acima da Formação Caobillas e, a segunda, ocupando as zonas costeiras, possuindo materiais carbonatados nas suas alternâncias sedimentares.

As águas que circulam pela Formação Vertientes são predominantemente bicarbonatadas cálcicas também com valores de STD> $1000 \mathrm{mg} / \mathrm{L}$ para 0 mesmo tipo classificado. Esta formação é de baixa aquosidade (Vide item IV 4.2.8.1) e a presença dos sulfatos, ainda em maiores proporções é justificada, entre as possibilidades, pela abundância de pirita nas mesmas. Justificada também é a presencia das águas cloretadas, mas, no caso é bem definida a sua ausência. Devido a sua posição estratigráfica, composição petrográfica e desenvolvimento geológico desta formação, justificarem-se-ia se nela houvessem águas cloretadas, ainda até se aprisionadas geologicamente. Neste caso apenas existem as águas bicarbonatadas e sulfatadas, sem coexistência reconhecível com as cloretadas, como acontece majoritariamente nos granodioritos de Las Tunas e a Formação Caobillas e, regularmente nos outros conjuntos rochosos. 

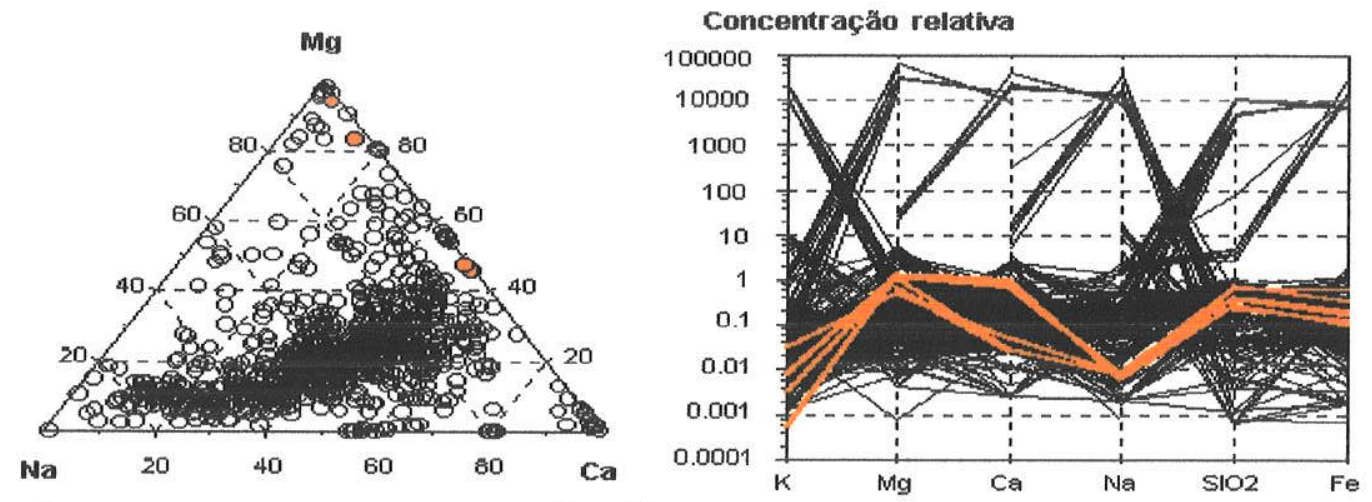

A

Argilas
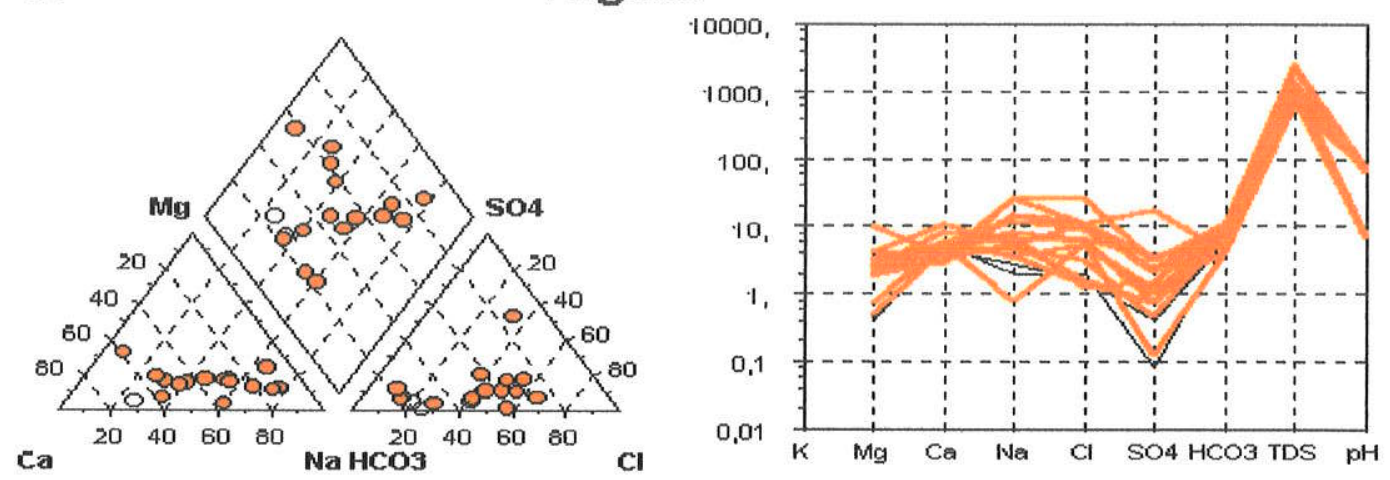

$\mathbf{B}$

Águas da Form. Vertientes
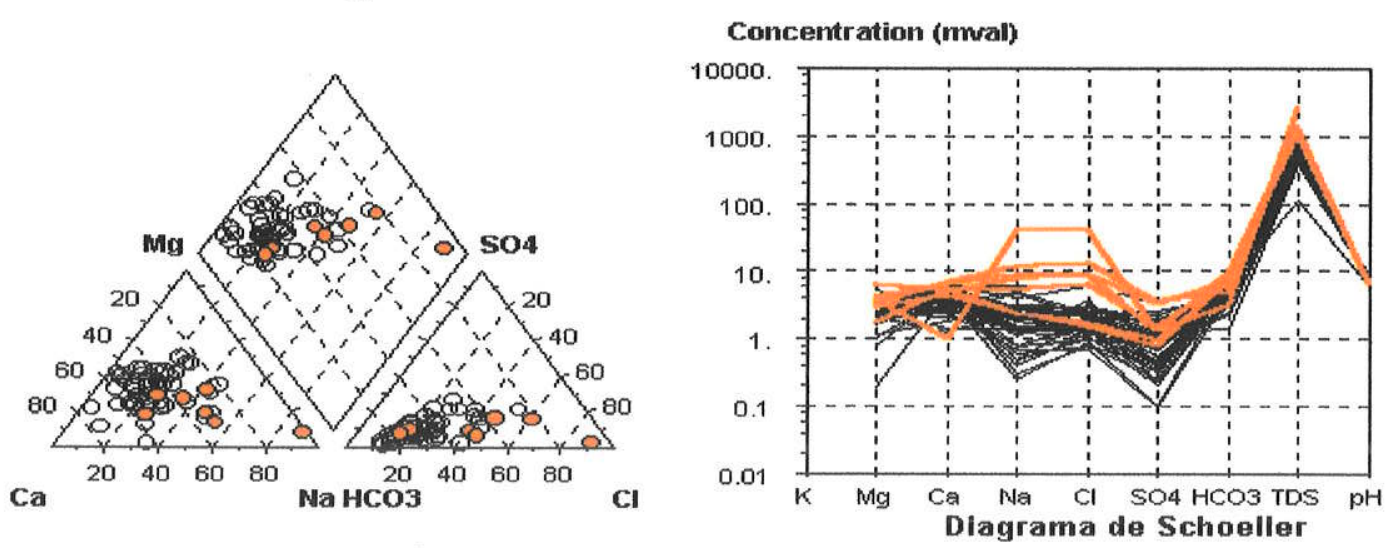

C

Águas da Form. Vila Roja

Legenda :

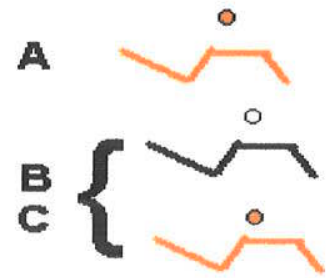

Pontos representativos do tipo litológico sob análise dentro do campo total do quimismos das rochas da região de estudo

Análises representativos das âguas subterrâneas que circulam nas litologias em referẻncia

Idem para as condiçöes de : Condutividade $>1000 \mu$ S/cm

Figura 39. Gráficos que comparam a composição química das rochas origem e das águas subterrâneas que circulam pela Formação Vertientes e Vila Roja

(Fonte de dados: Rodriguez, 1996 e Padrón Martín, 1998) 
maior que $1000 \mathrm{mg} / \mathrm{L}$ de STD. A interpretação desta coexistência em particular pode ser devida à distribuição litoránea desta formação.

\section{Classificação dos tipos hidroquímicos das águas subterrâneas associados aos conjuntos litológicos da sua circulação}

No capítulo anterior evidenciou-se que os tipos hidroquímicos resultantes da circulação no meio rochoso correspondiam com a composição química predominante das respectivas rochas. A Tabela 6 apresenta um resumo de todo o deduzido e constatado.

Pode apreciar-se que a proporção mais abundante da rocha domina a composição catiônica da respectiva água e quando a abundância na rocha é equilibrada com mais de um componente catiônico, o tipo de água resultante é predominantemente misto, e o possível predomínio de um sobre o outro no tipo hidroquímico da água, pode considerar-se local.

A classificação das águas subterrânea foi avaliada segundo o conjunto litológico particular, a partir dos gráficos de Piper e de Schoeller. A Figura 40 apresenta um resumo das classificações das águas pelo método de Piper. As cores aplicadas conceberam-se para manter a referência à idade geológica da rocha de procedência. Nota-se que o tipo hidrogeoquímico de maior nitidez, enquanto posição da figura desenhada no diagrama, é o derivado dos peridotitos e serpentinitas. O seguinte,é o derivado dos calcários, mas a nitidez da figura faz-se já mais dispersa enquanto o seu contorno cresce há outras proporções químicas. As restantes, apesar de possuir sua classificação própria, suas configurações no diagrama de Piper não ocupam uma proporção química bem precisa.

As classificações hidrogeoquímicas das águas podem ser vistas também através dos gráficos semilogarítmicos de Schoeller. A Figura 41 apresenta um resumo das classificações avaliadas nas litologias de procedência. As cores mantêm-se com o mesmo critério que a figura precedente de Piper. 
Tabela 6 . Resumo da análise da composição química dos tipos litológicos selecionados na região de estudo e da classificação das águas subterrâneas neles contidas.

\begin{tabular}{|c|c|c|c|c|c|c|c|}
\hline Litologia & $\begin{array}{c}\text { No. de } \\
\text { pontos } \\
\text { selecionados }\end{array}$ & $\begin{array}{c}(\mathrm{CR}) \\
\text { Componente } \\
\text { Representativo } \\
\text { (Ternário) }\end{array}$ & $\begin{array}{c}\text { Relações de } \\
\text { concentrações } \\
\text { relativas } \\
\text { (semilogarítmico) }\end{array}$ & $\begin{array}{l}\text { Valores } \\
\text { relativos } \\
\text { máximos } \\
\text { do CR }\end{array}$ & $\begin{array}{l}\text { Valores } \\
\text { relativos } \\
\text { mínimos do } \\
\text { comp. } \\
\text { menor }\end{array}$ & $\begin{array}{l}\text { Valores } \\
\text { relativos } \\
\mathrm{SiO}_{2}\end{array}$ & $\begin{array}{c}\text { Tipo Hidroquímico } \\
\text { de água }\end{array}$ \\
\hline $\begin{array}{c}\text { Peridotitos } \\
\text { Serpentinitos }\end{array}$ & 7 & $\mathrm{Mg}$ & $\mathrm{Mg}>\mathrm{Ca}>\mathrm{Na}$ & $1-10$ & $\begin{array}{c}\mathrm{Na}(0.001- \\
0.01)\end{array}$ & 1 & $\mathrm{MgHCO}_{3}$ \\
\hline Granitos & 10 & $\mathrm{Na}$ & $\mathrm{Na}>\mathrm{Ca} \sim \mathrm{Mg}$ & $0.1-1$ & $\mathrm{Mg}(0.01-0.1)$ & 1 & $\mathrm{NaHCO}_{3}$ \\
\hline Dioritos & 8 & $\mathrm{Ca}$ & $\mathrm{Ca} \sim \mathrm{Mg}>\mathrm{Na}$ & $0.1-1$ & $\mathrm{Na}(0.1)$ & 1 & - \\
\hline Granodioritos & 14 & $\mathrm{Na}$ & $\mathrm{Na} \sim \mathrm{Ca} \sim \mathrm{Mg}$ & $0.1-1$ & --- & 1 & $\mathrm{Na}-\mathrm{Ca}\left(\mathrm{HCO}_{3}\right)$ \\
\hline Basaltos & 9 & $\mathrm{Mg}$ & $\mathrm{Mg}>\mathrm{Ca}>\mathrm{Na}$ & $0.1-1$ & $\mathrm{Na}(0.01-0.1)$ & $0.1-1$ & \multirow{3}{*}{$\begin{array}{c}\mathrm{Ca}-\mathrm{Na}\left(\mathrm{HCO}_{3}\right) \\
(\mathrm{Fm} . \mathrm{Cnt}) \\
\\
\mathrm{Na}-\mathrm{Ca}\left(\mathrm{HCO}_{3}\right) \\
\text { (Fm. Cao) }\end{array}$} \\
\hline Lavas & 6 & $\mathrm{Mg}$ & $\mathrm{Mg}>\mathrm{Ca}>\mathrm{Na}$ & $0.1-1$ & $\mathrm{Na}(0.1)$ & $0.1-1$ & \\
\hline Tufos & 7 & $\mathrm{Ca}$ & $\mathrm{Ca}>\mathrm{Mg} \sim \mathrm{Na}$ & $0.1-1$ & $\mathrm{Na}(0.1)$ & $0.1-1$ & \\
\hline $\begin{array}{c}\text { Rochas } \\
\text { carbonatadas }\end{array}$ & 12 & $\mathrm{Ca}$ & $\mathrm{Ca}>>\mathrm{Mg}>\mathrm{Na}$ & $1-10$ & $\begin{array}{c}\mathrm{Na}(0.001- \\
0.01)\end{array}$ & 0.1 & $\mathrm{CaHCO}_{3}$ \\
\hline Argilas & 8 & $\mathrm{Mg}$ & $\mathrm{Mg} \sim \mathrm{Ca}>\mathrm{Na}$ & $1-10$ & $\begin{array}{l}\mathrm{Na}(0.001- \\
0.01)\end{array}$ & $0.1-1$ & $\mathrm{CaHCO}_{3}$ \\
\hline
\end{tabular}

(Fonte : Padrón Martin , 1998) 


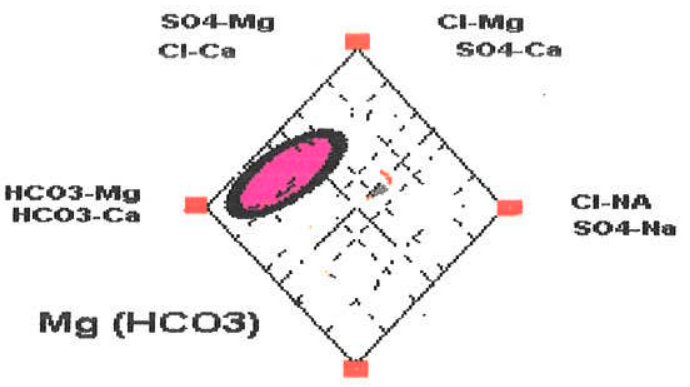

HCO3-Na

Peridotitos e Serpentinitas

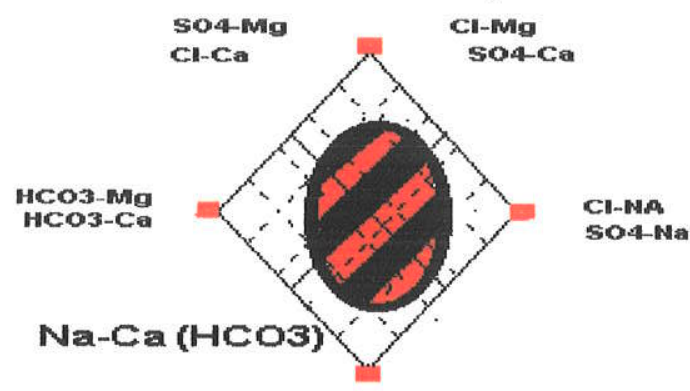

HCO3-Na

Granodioritos

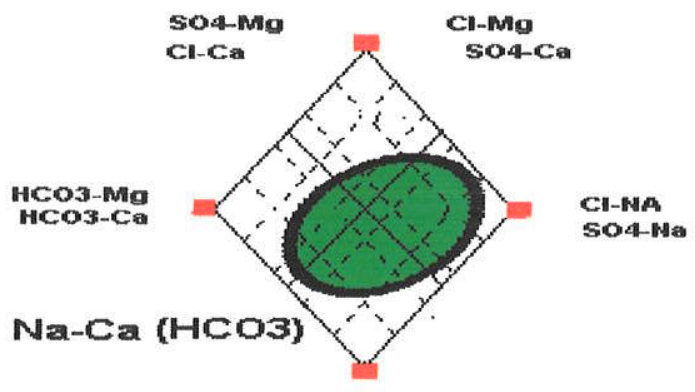

HCO3-No

Form. Caobillas

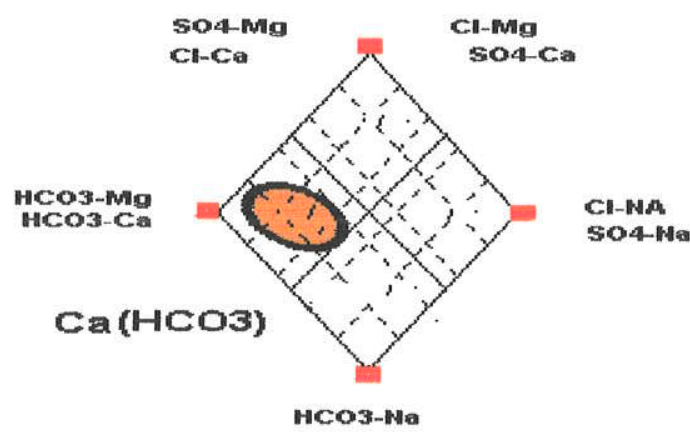

Form. Vertientes

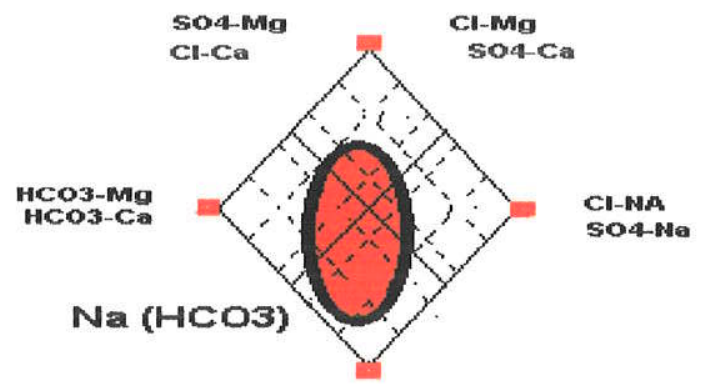

HCO3-Na

Granitos

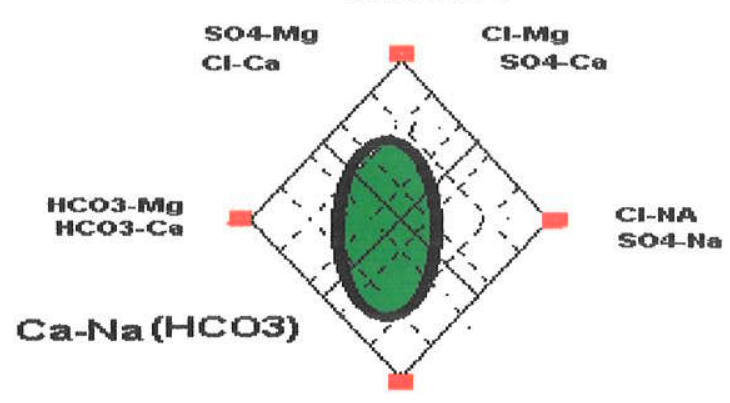

HCO3-Na

Form. Contramaestre

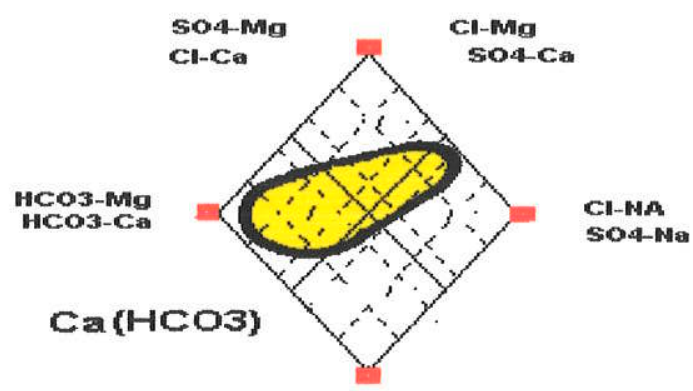

HCO3-Na

Form. Guines

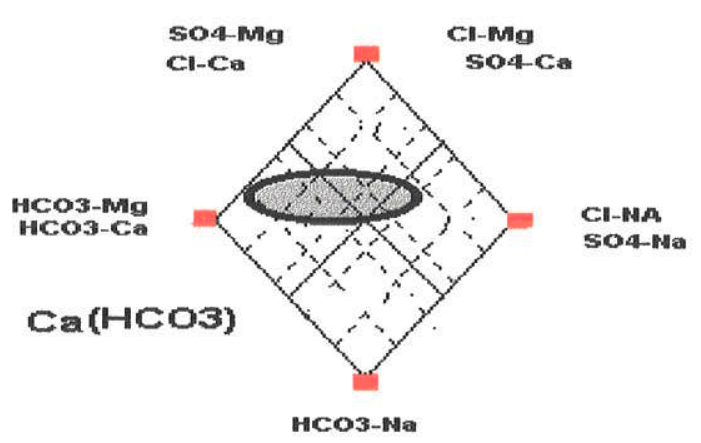

Form. Vila Roja

Figura 40. Apresentação nos diagramas de Piper das classificações representativas características das águas subterrâneas que circulam pelos diferentes conjuntos litológicos analisados. 

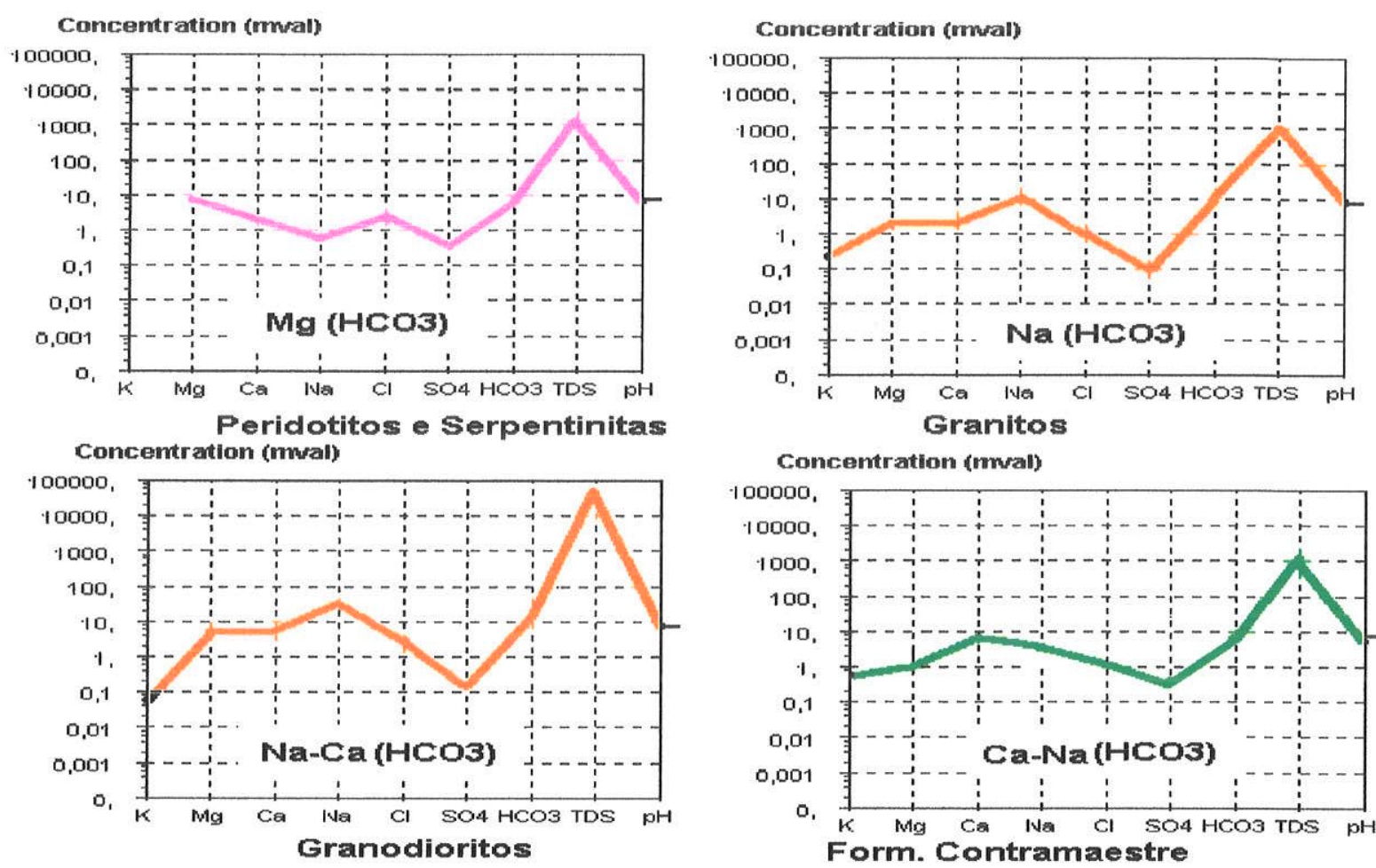

Concentration (nmal)

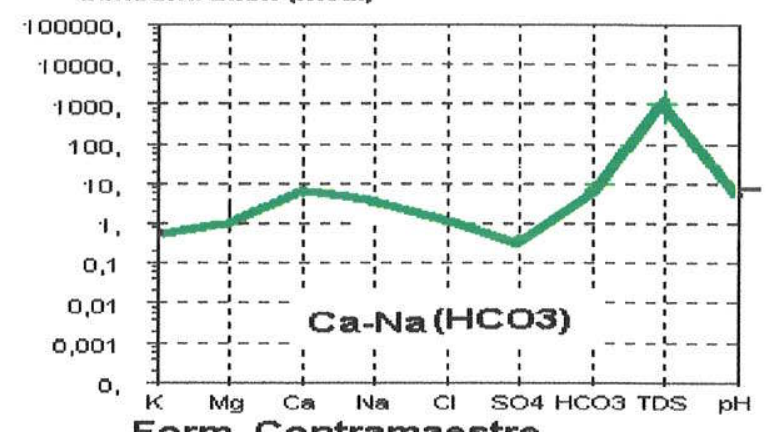

Form. Contramaestre

Concentration (mmal)

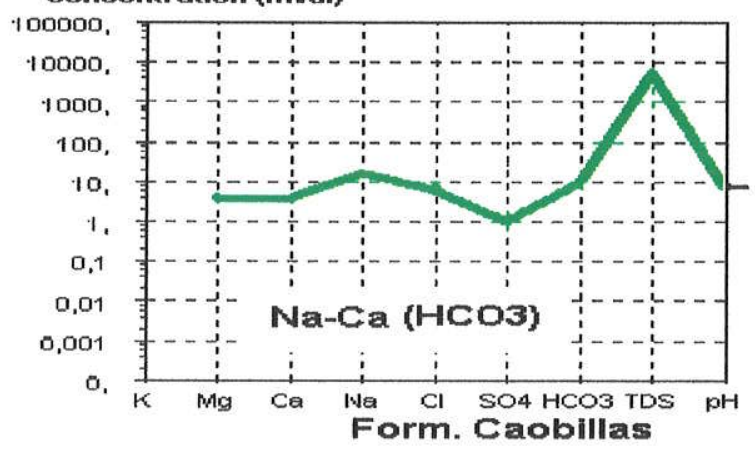

Concentration (mmal)

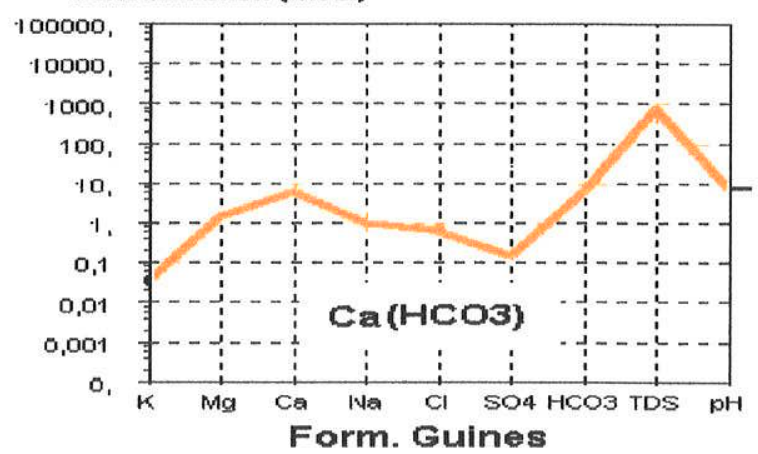

Concentration (mval)
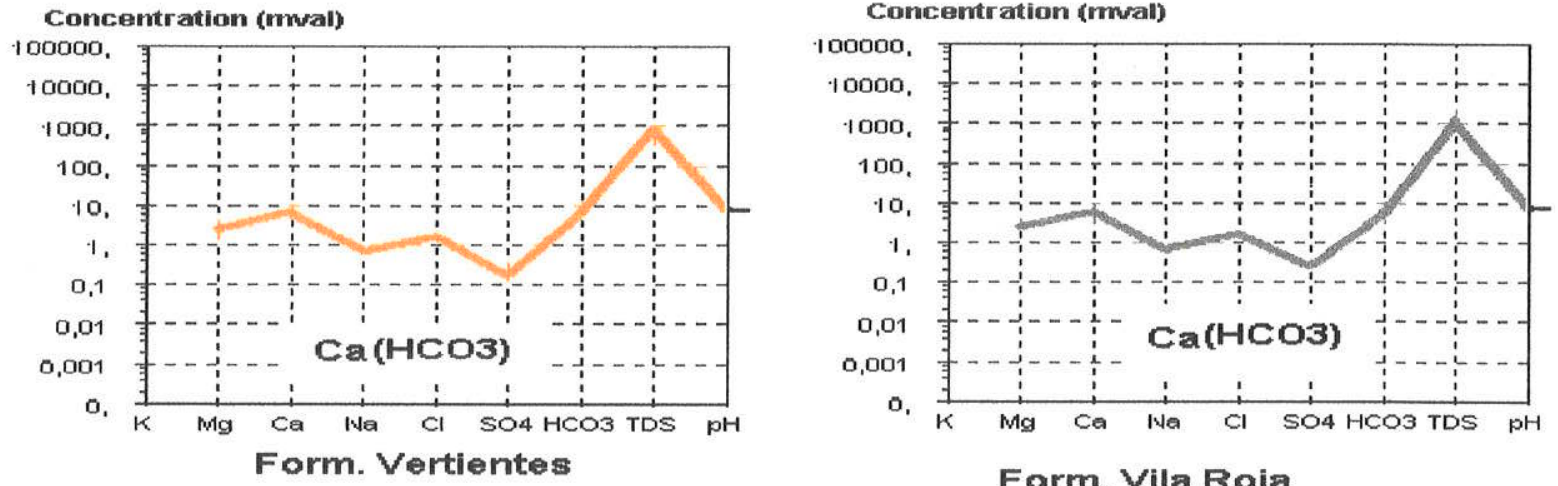

Form. Vila Roja

Figura 41 Resumo das classificações dos tipos de águas que circulam pelos diferentes meios litológicos a partir da esquematização do conjunto de linhas do Diagrama Semilogarítmico de Schoeller. 


\section{Estabelecimento da correspondência da dissociação dos componentes aniônicos principais com a concentração da solução para cada tipo hidrogeoquímico determinado}

A análise das correspondências do quimismo das águas subterrâneas com o quimismo das suas respectivas rochas pelas quais circulam não teve como objetivo principal do capítulo anterior, determinar a coexistência comum do tipo cloretado sódico em cada avaliação. É interesse neste capítulo avaliar o comportamento dos componentes aniônicos dos tipos hidrogeoquímicos estabelecidos e definir as similaridades ou diferenças dentro da solução dinâmica que constitui a água subterrânea, e cumprir com os pontos específicos propostos para o processamento dos dados na metodologia (Capítulo V). Estes são: (4) Estabelecer a correspondência da dissociação dos componentes principais com a concentração da solução para cada tipo hidrogeoquímico determinado; (5) Avaliar os limites da estabilidade destas correspondências para o prognóstico do comportamento das águas em concentrações acima das águas subterrâneas comuns.

Ainda que o tipo aniônico dominante tenha sido sempre o bicarbonatado, o cloretado apareceu com uma freqüência perceptível. Uns dos fatores da distorção das figuras de cada tipo hidrogeoquímico nos respectivos gráficos Piper na Figura 40, foi devida, principalmente, à presencia dos cloretos de sódio.

Considerando a qualidade, representatividade e confiabilidade dos valores da informação utilizada, resulta evidente a inexistência de erros e a necessidade de esclarecer a causal ou casualidade do comportamento apresentado.

O processamento dirigiu-se a analisar e precisar o comportamento dos ânions dominantes na dissolução água e os limites das condicionantes dos seus domínios. Mantive-se os mesmos grupos de águas analisadas anteriormente, devido à necessidade de manter a evolução das mesmas referências.

\section{-Serpentinitos e peridotitos}

A Figura 42 apresenta a correlação gráfica entre a condutividade $(\mu \mathrm{S} / \mathrm{cm})$ e os Sólidos Totais dissolvidos, STD, (mg/L) com os ânions cloretos, bicarbonatos e sulfatos (meq/L) respectivamentes nas águas subterrâneas que circulam a través dos maciços de serpentinitas e peridotitos. Os valores calculados das respectivas correlações para cada grupo aparecem na Tabela 7.

Nota-se correlações significativas para os gráficos dos STD e o $\mathrm{Cl}$. Pode-se precisar uma continuidade desde os valores mínimos para a relação Cond/STD, enquanto que percebe-se uma continuidade na relação $\mathrm{Cond} / \mathrm{Cl}$, a partir dos $1000(\mu \mathrm{S} / \mathrm{cm})$. A correlação gráfica e analítica dos $\mathrm{HCO}_{3}$ e $\mathrm{SO}_{4} \mathrm{com}$ respeito à Condutividade não é significativa. Nota-se no caso dos bicarbonatos que existe linearidade certa até os $1000(\mu \mathrm{S} / \mathrm{cm})$ e $10 \mathrm{meq} / \mathrm{L}$, a partir dos quais, o bicarbonato diluído faz-se constante na solução. No caso do $\mathrm{SO}_{4}$ parece existir uma tendência, mas ainda não muito definido. 

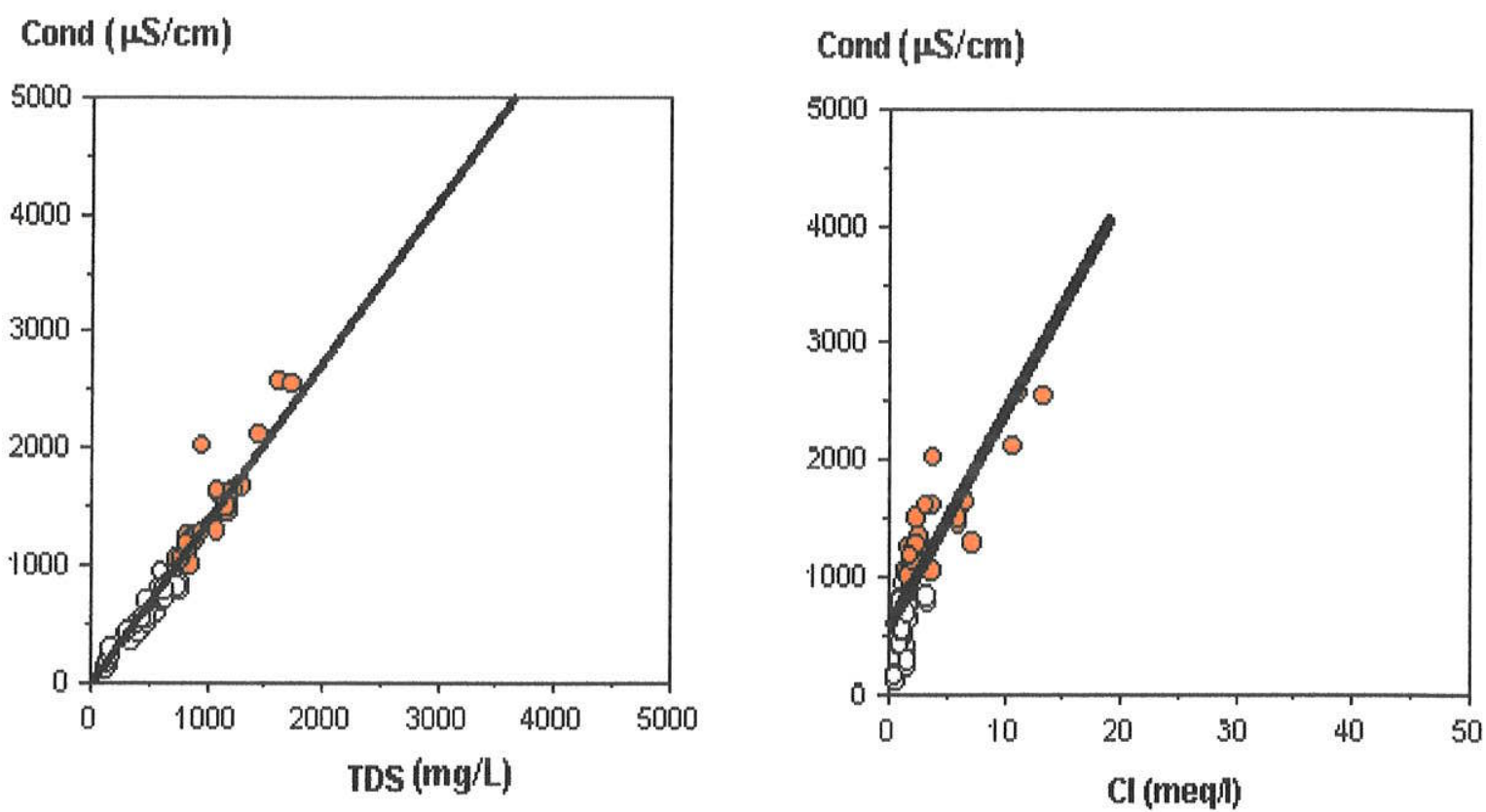

Cond $(\mu \mathrm{S} / \mathrm{cm})$

Cond $(\mu \mathrm{S} / \mathrm{cm})$
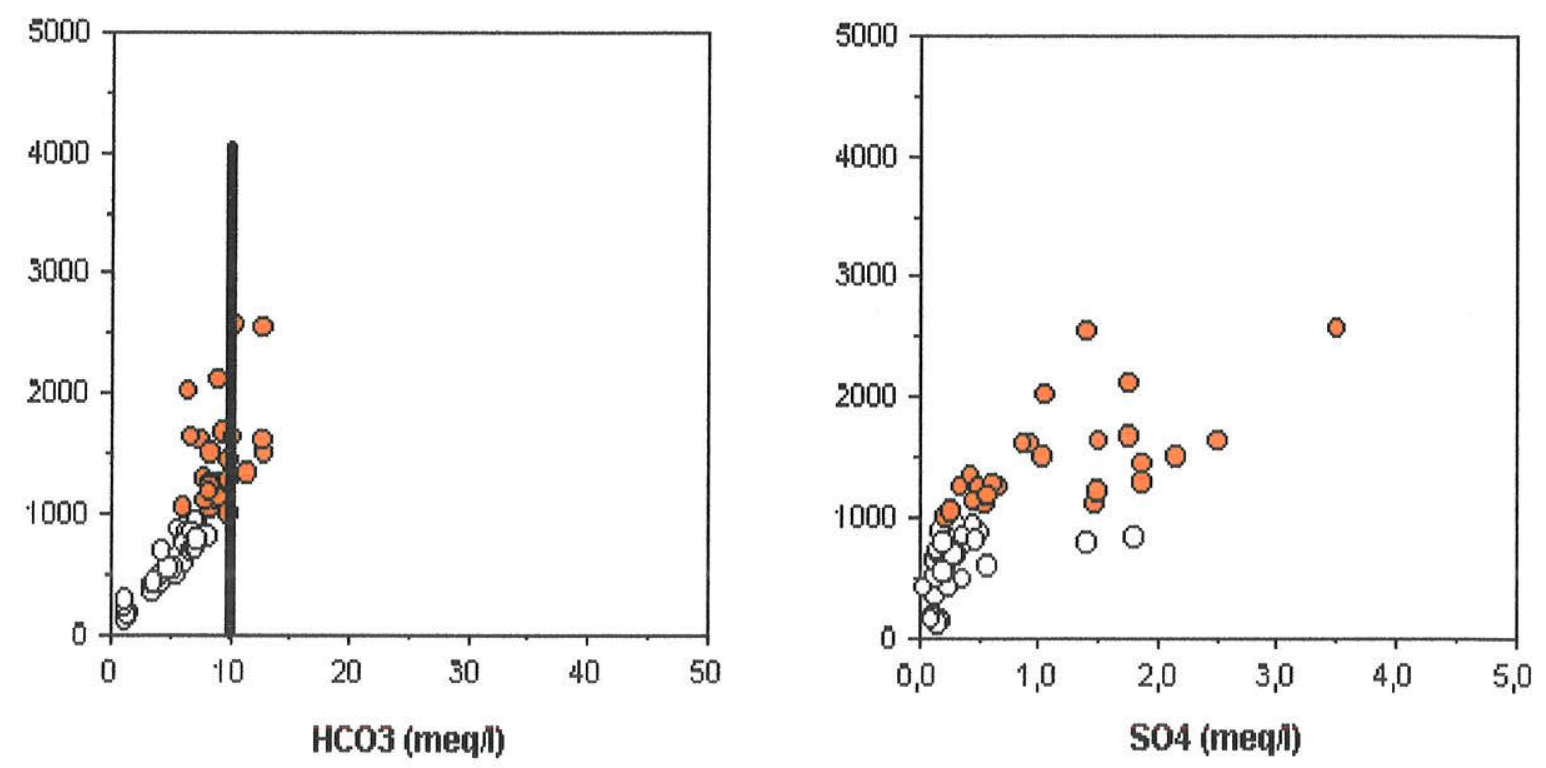

Legenda :

Condutividade $>1000 \mu$ Sicm

Tendência ou limitação do comportamento dos pontos

Figura 42. Correlação gráfica dos componentes aniónicos principais em meq/L com respeito à Condutividade em $\mu S / \mathrm{cm}$ nas águas subterrâneas que circulam através dos serpentinitas e peridotitos.

(Fonte : Rodriguez et al, 1996) 
Tabela 7. Resultados das correlações entre a condutividade elétrica e $\mathrm{Cl}^{-}, \mathrm{SO}_{4}{ }^{\circ}, \mathrm{HCO}_{3}{ }^{-}$e STD das águas subterrâneas na área de estudo, Cuba Centro-Oriental.

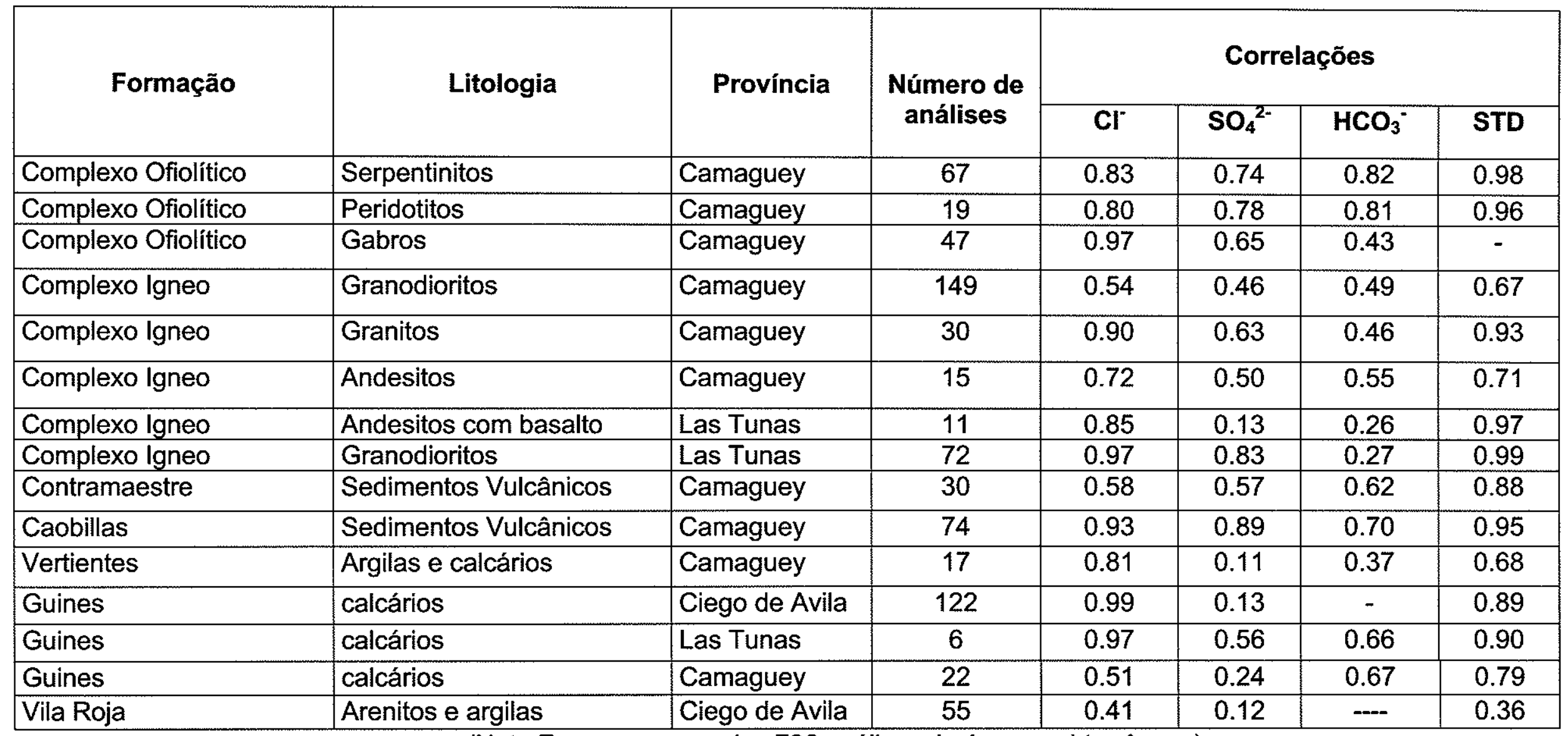

(Nota:Foram processados 736 análises de águas subterrâneas) 


\section{-Granitos de Camaguey}

Na Figura 43 nota-se que os componentes aniônicos das águas que circulam pelos granitos de Camaguey têm comportamentos similares ao caso anterior quanto aos STD, $\mathrm{Cl}, \mathrm{HCO}_{3}$ e $\mathrm{SO}_{4}$. Este último parece estabilizar o aumento da sua concentração entre os 2000 e $3000(\mu \mathrm{S} / \mathrm{cm})$.

\section{-Granodioritos de Las Tunas e Camaguey}

As Figuras 44 e 45 apresentam o comportamento das relações nas águas dos granodioritos de Camaguey e Las Tunas, respectivamente, que, como foi explicado anteriormente, formam parte do mesmo corpo que afloram nas distintas províncias. O comportamento dos STD,cloreto e bicarbonato é o mesmo dos casos anteriores. O sulfato aumenta linearmente a sua concentração a partir da condutividade superior aos $1000 \mu \mathrm{S} / \mathrm{cm}$.

\section{-Formação Contramaestre}

A Figura 46 não apresenta tanta nitidez no comportamento dos ânions com respeito à condutividade. Pode ser visto com maior nitidez o aumento da concentração dos sulfatos para a faixa entre 1000 e $2000 \mu \mathrm{S} / \mathrm{cm}$ da condutividade.

\section{-Formação Caobillas}

A Figura 47 permite apreciar que o comportamento dos STD e os ânions cloretos e bicarbonatos são similares aos anteriores conjuntos litológicos. No caso do sulfato, por ter uma concentração maior nota-se uma tendência a estabilizar sua dissociação em volta dos $20-30 \mathrm{meq} / \mathrm{L}$. Um ponto acima dos 40 $\mathrm{meq} / \mathrm{L}$ parece um possível erro. Será analisado no contexto de outros elementos mais adiante.

\section{-Formação Vertientes}

A formação Vertiente e Guines pertencem ao Cenozóico cubano. As condições de formação são muitos diferentes aos casos anteriores, nos quais predominava o componente igneo. Neste sentido, pode-se esperar um comportamento da dissolução distinto dos precedentes, caso a composição petrográfica influísse.

Aprecia-se na Figura 48 a continuação da linearidade da concentração para os STD e os cloretos, a limitação dos bicarbonatos aos $10 \mathrm{meq} / \mathrm{L}$ e o aumento da concentração dos sulfatos para os valores maiores dos $1000 \mu \mathrm{S} / \mathrm{cm}$, similares para as litologias já descritas.

\section{-Formação Guines de Ciego de Avila}

A particularidade mais destacada da Formação Guines é o seu caráter carbonatado e karstificado que a faz ser o aqüifero principal de Cuba. 
Cond $(\mu \mathrm{S} / \mathrm{cm})$

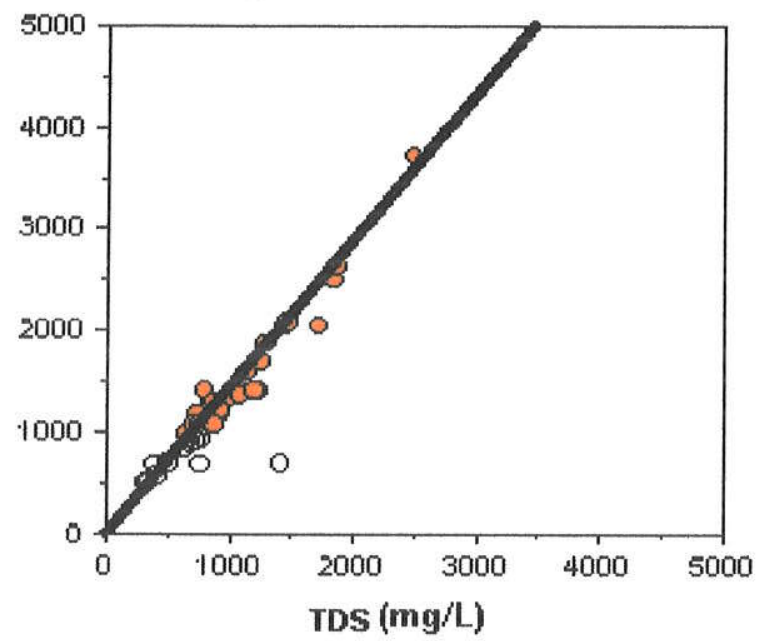

Cond $(\mu \mathrm{S} / \mathrm{cm})$

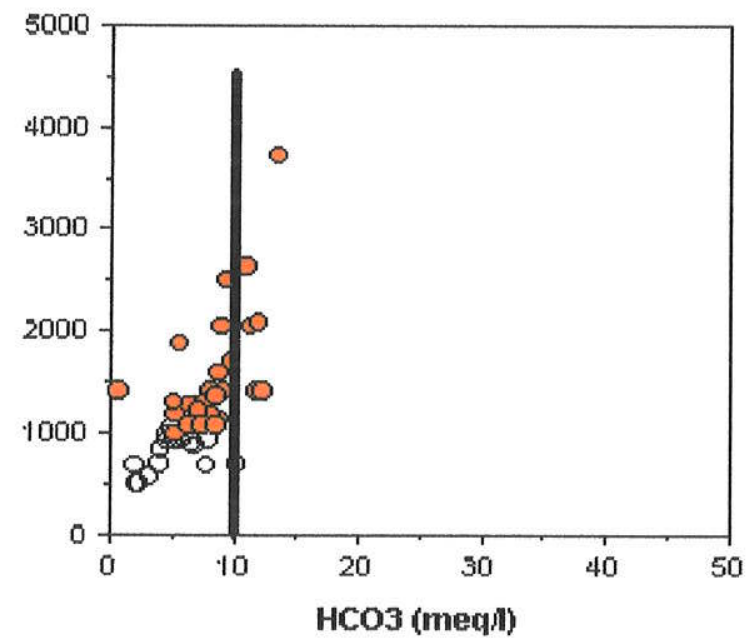

Cond $(\mu \mathrm{S} / \mathrm{cm})$

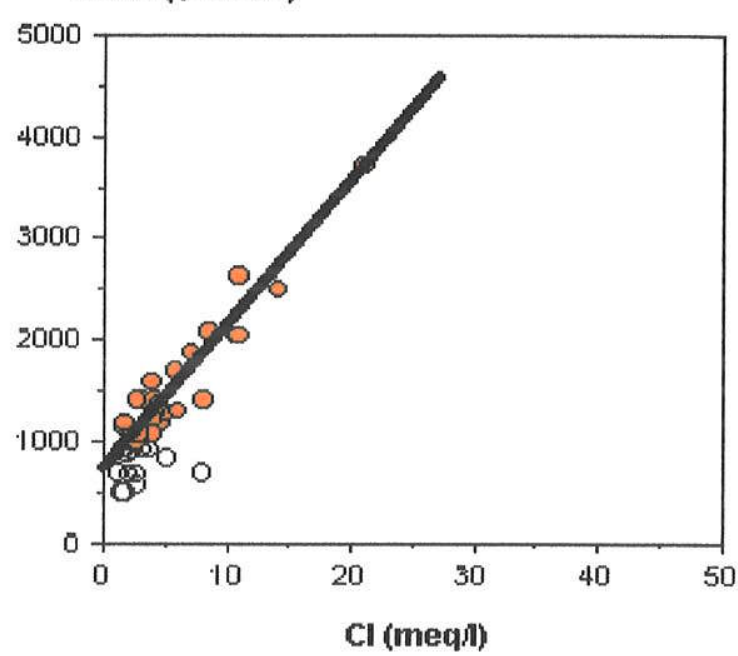

Cond ( $\mu \mathrm{S} / \mathrm{cm})$

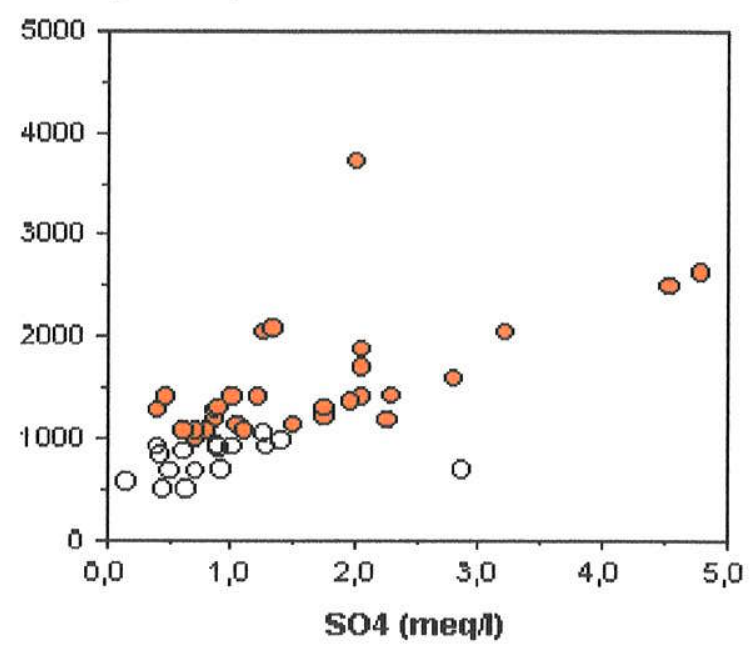

\section{Legenda :}

- Condutividade $>1000 \mu \mathrm{S} / \mathrm{cm}$

Tendência ou limitação do comportamento dos pontos

Figura 43. Correlação gráfica dos componentes aniônicos principais em meq/L com respeito à Condutividade em $\mu S / \mathrm{cm}$ nas águas subterrâneas que circulam através dos granitos de Camaguey.

(Fonte : Rodriguez et al, 1996) 
Cond $(\mu \mathrm{S} / \mathrm{cm})$

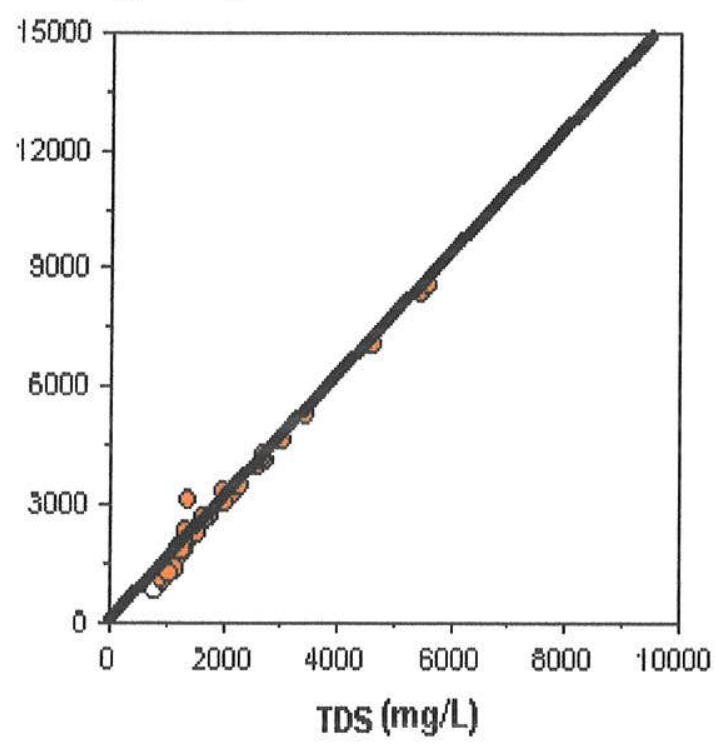

Cond $(\mu \mathrm{S} / \mathrm{cm})$

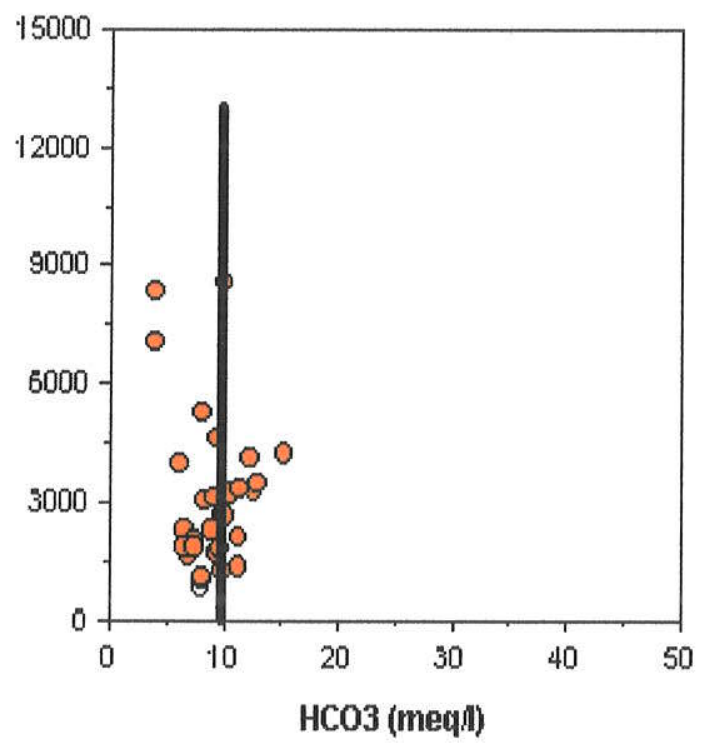

Cond $(\mu \mathrm{S} / \mathrm{cm})$

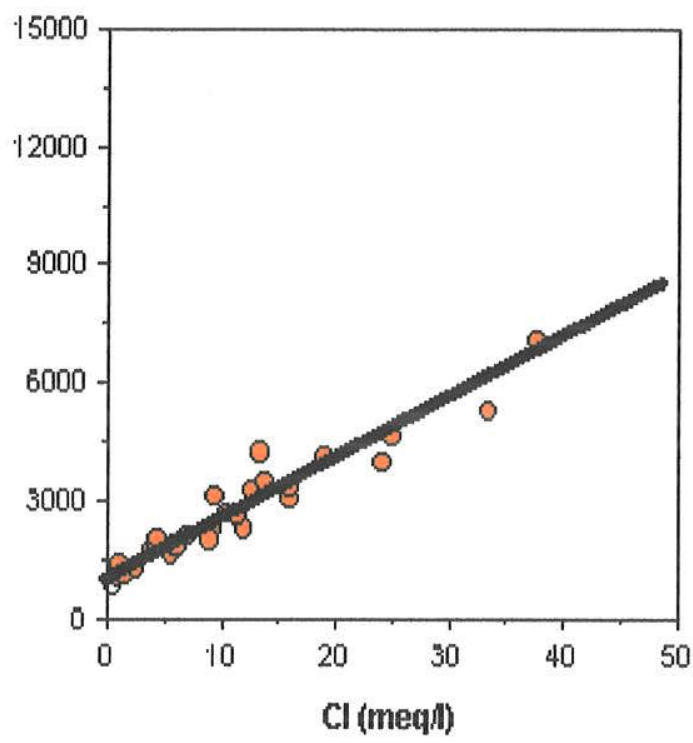

Cond $(\mu \mathrm{S} / \mathrm{cm})$

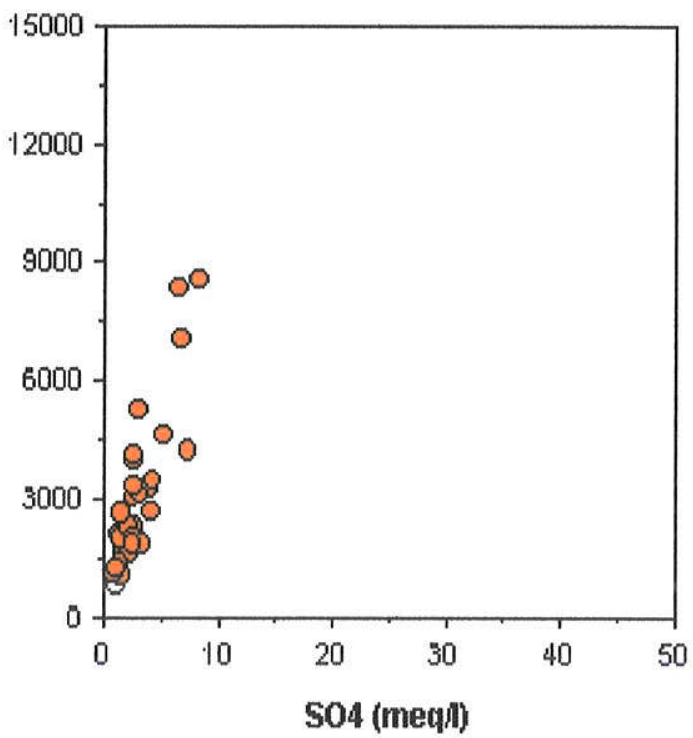

\section{Legenda :}

Condutividade $>1000 \mu$ S/cm

Tendência ou limitação do comportamento dos pontos

Figura 44. Correlação gráfica dos componentes aniónicos principais em meq/L com respeito à Condutividade em $\mu \mathrm{S} / \mathrm{cm}$ nas águas subterrâneas que circulam através dos granodioritos de Camaguey.

(Fonte : Rodriguez et al, 1996) 


\section{Cond $(\mu \mathrm{S} / \mathrm{cm})$}

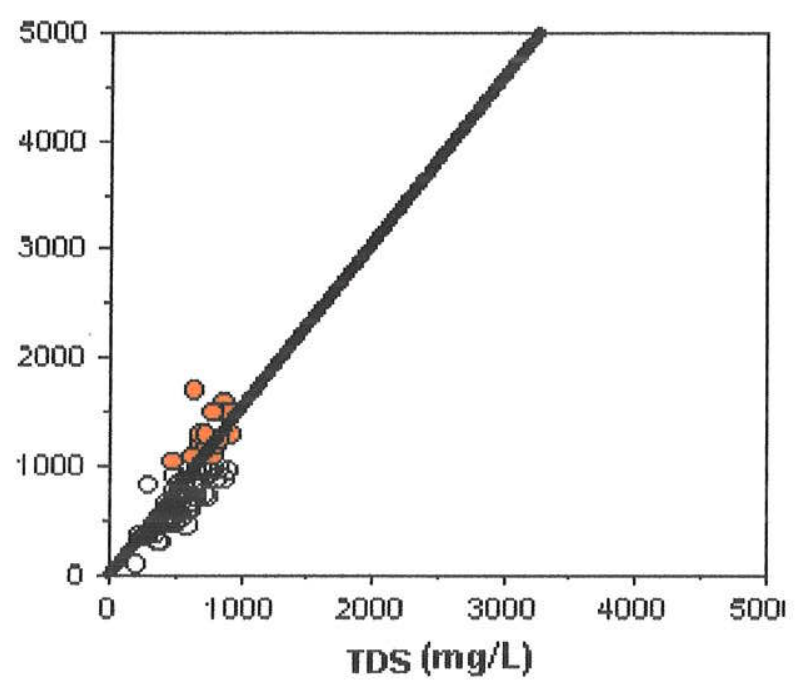

Cond ( $1 \mathrm{~S} / \mathrm{cm})$

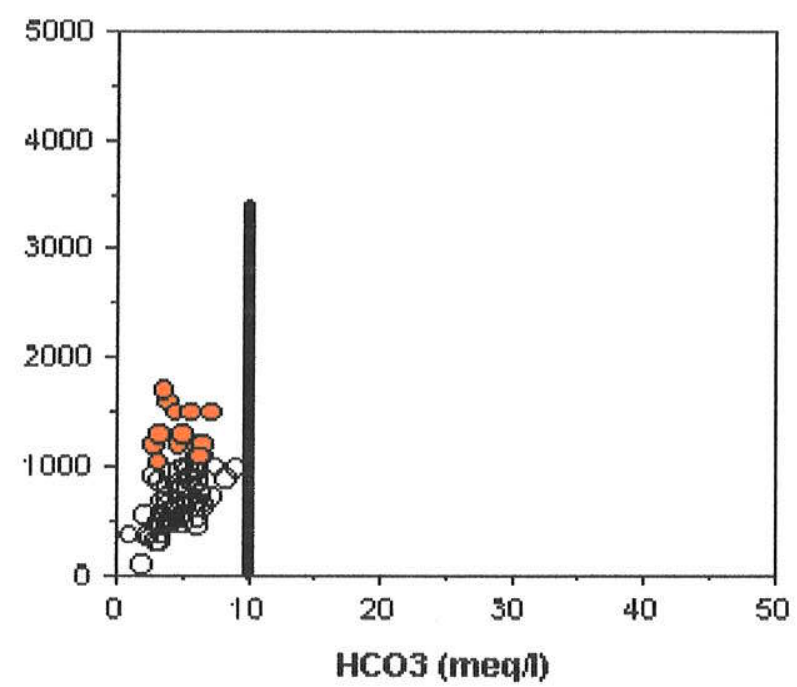

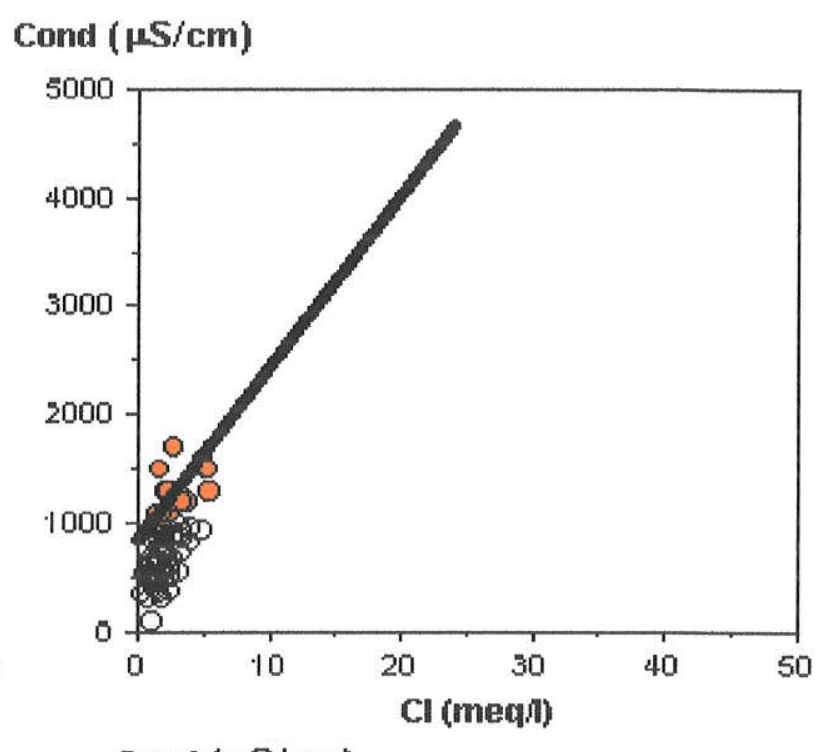

Cond $(\mu \mathrm{S} / \mathrm{cm})$

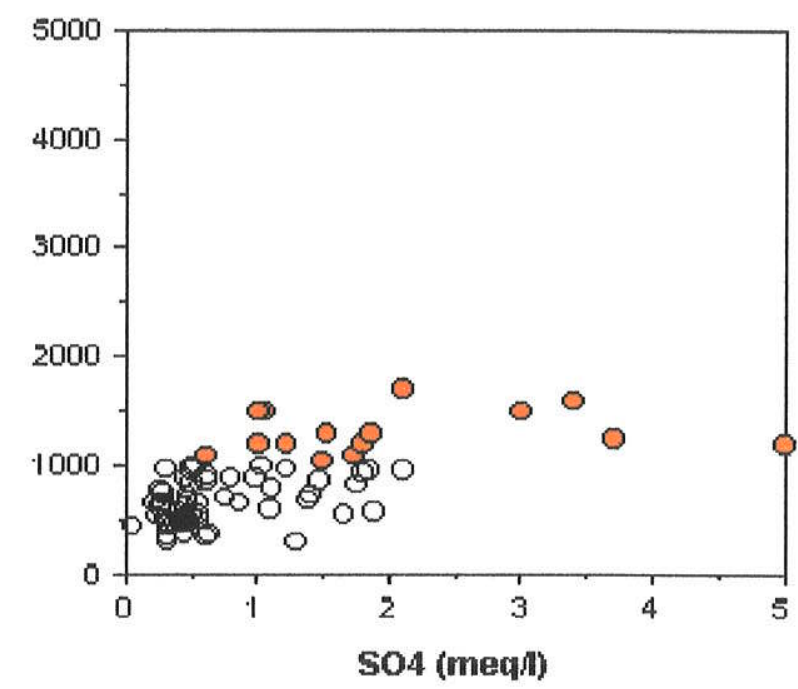

\section{Legenda :}

Condutividade $>1000 \mu$ S/cm

Tendência ou limitação do comportamento dos pontos

Figura 45. Correlação gráfica dos componentes aniônicos principais em $\mathrm{meq} / \mathrm{L}$ com respeito à Condutividade em $\mu \mathrm{S} / \mathrm{cm}^{2}$ nas águas subterrâneas que circulam através dos granodioritos de Las Tunas.

(Fonte : Rodriguez et al, 1996) 

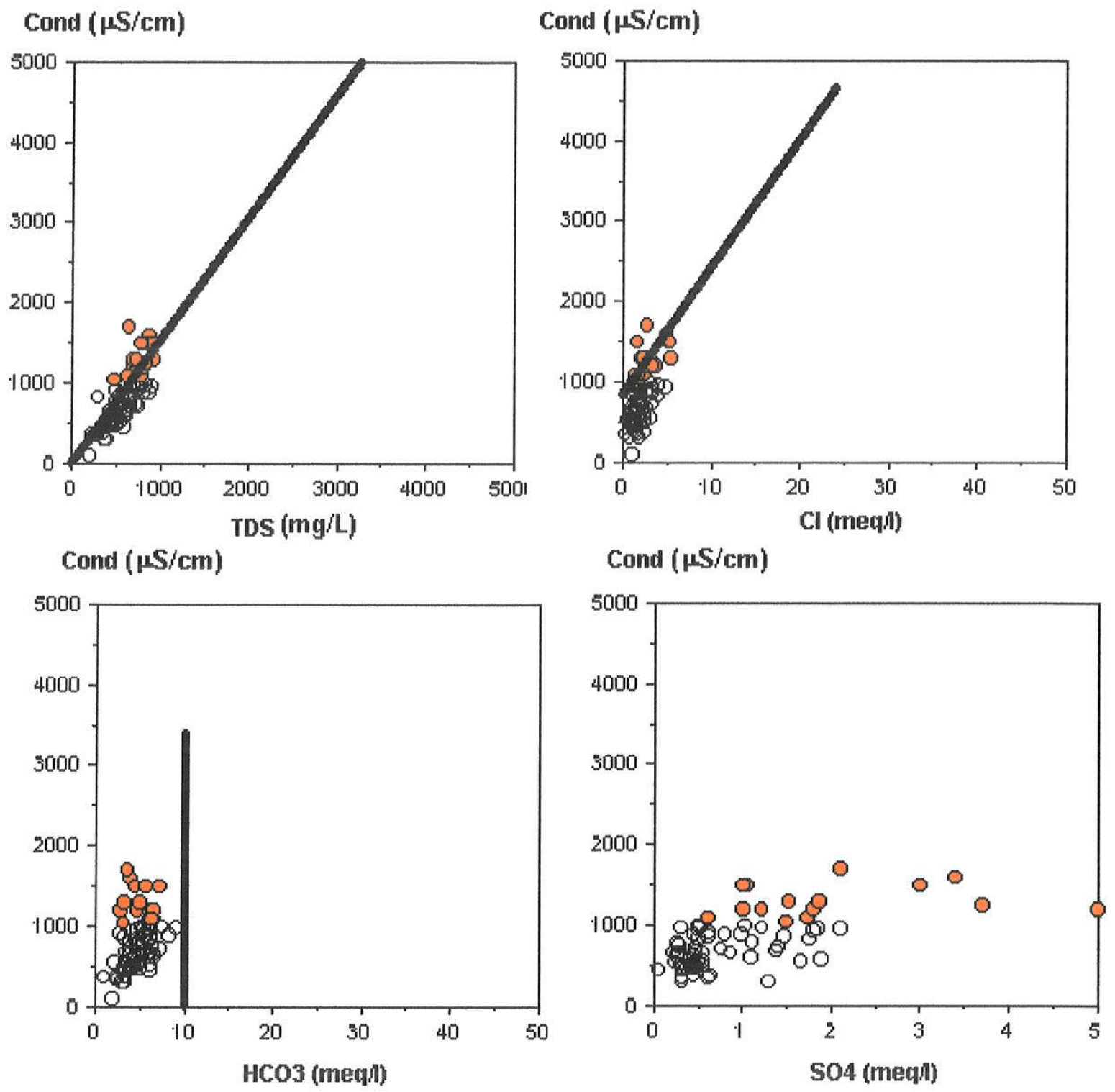

\section{Legenda :}

C Condutividade $>1000 \mu$ Sicm

Tendência ou limitação do comportamento dos pontos

Figura 46. Correlação gráfica dos componentes aniônicos principais em $\mathrm{meq} / \mathrm{L}$ com respeito à Condutividade $\mathrm{em} \mu \mathrm{S} / \mathrm{cm}$ nas águas subterrâneas que circulam através da Formação Contramaestre.

(Fonte : Rodriguez et al, 1996) 

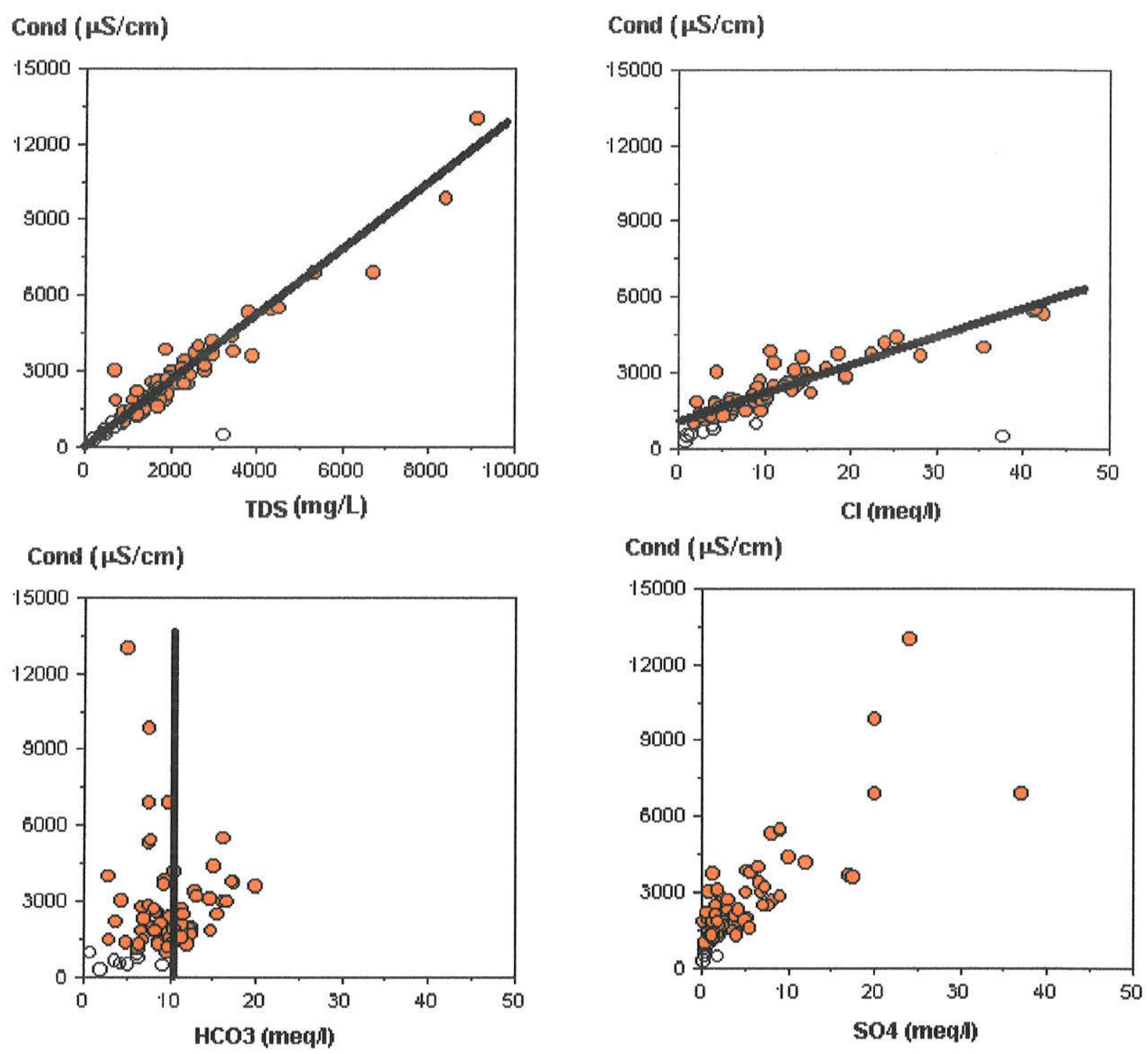

\section{Legenda :}

- Condutividade $>1000 \mu \mathrm{S} / \mathrm{cm}$

Tendência ou limitação do comportamento dos pontos

Figura 47. Correlação gráfica dos componentes aniônicos principais em meq/L com respeito à Condutividade em $\mu S / \mathrm{cm}$ nas águas subterrâneas que circulam através da Formação Caobillas.

(Fonte : Rodriguez et al, 1996) 

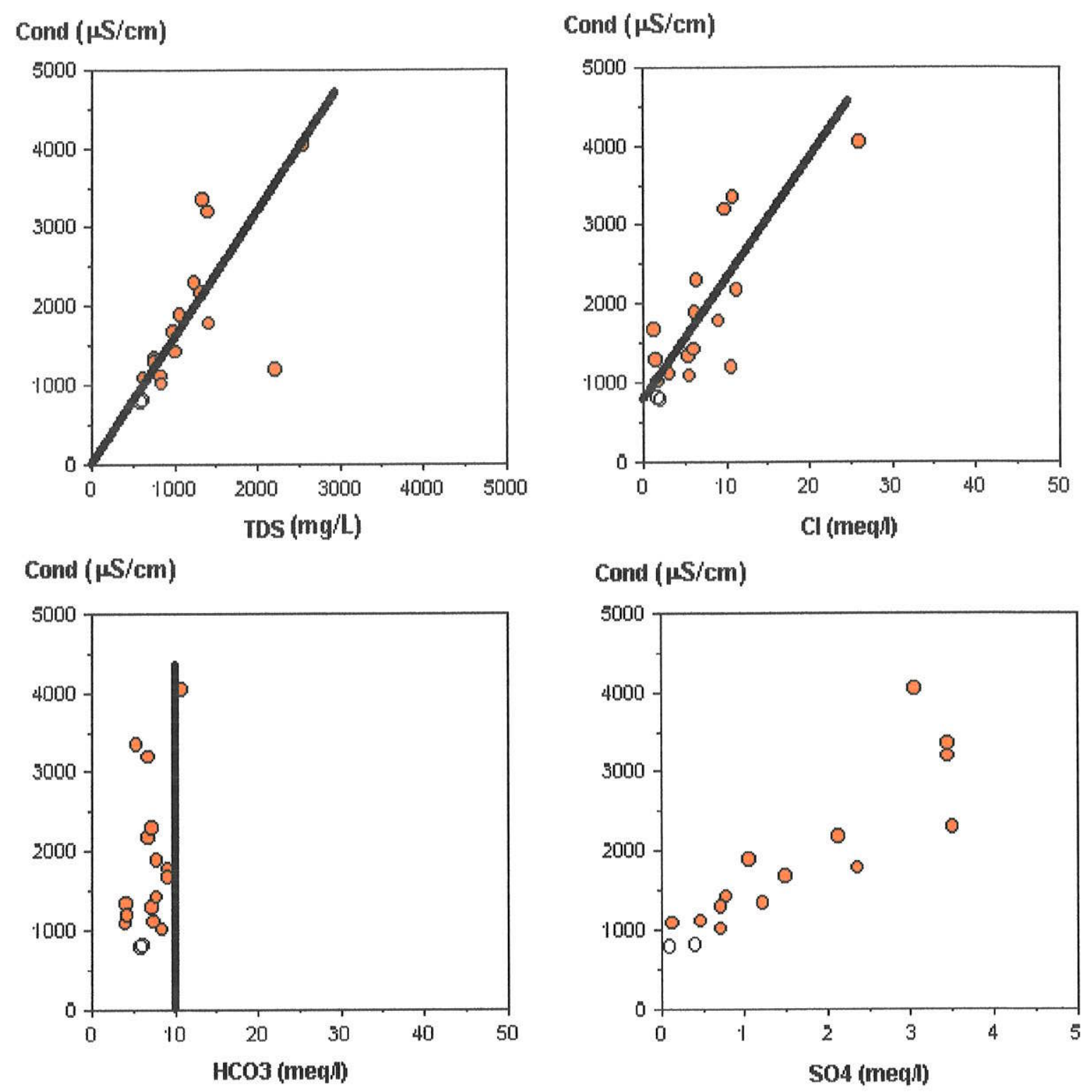

\section{Legenda :}

Condutividade $>1000 \mu \mathrm{Sicm}$

Tendência ou limitação do comportamento dos pontos

Figura 48. Correlação gráfica dos componentes aniónicos principais $\mathrm{em} \mathrm{meq} / \mathrm{L}$ com respeito a Condutividade em $\mu \mathrm{S} / \mathrm{cm}$ nas águas subterrâneas que circulam através da Formação Vertientes.

(Fonte : Rodriguez et al, 1996) 
Aprecia- se na Figura 49 as mesmas tendências reconhecidas para os restantes conjuntos litológicos. Cabe aqui lembrar a tendência linear atribuída aos carbonatos em solução que recomendavam-no como um parâmetro hidroquímico sem limite algum (Item III, 5.2). Evidencia-se que o referido parâmetro fica limitado para valores menores de $10 \mathrm{meq} / \mathrm{L} e$ concentrações menores de $1000 \mu \mathrm{S} / \mathrm{cm}$, o que elimina a sua universalidade dentro das águas subterrâneas.

\subsection{Outras considerações da dissociação dos ânions}

A Figura 50 agrupa os gráficos Condutividade/ $\mathrm{Cl}$ para os conjuntos litológicos representados pelos granodioritos Las Tunas, Form. Caobilla, Form. Vertientes e Form. Guines, visando estabelecer uma comparação com grupos de diferentes composições petrográficas e condições de gêneses. O resultado evidencia-se: a correlação condutividade $(\mu \mathrm{S} / \mathrm{cm}) / \mathrm{Cl}(\mathrm{meq} / \mathrm{L})$ é comum para todas as águas subterrâneas e independente da composição petrográfica pelas quais circulam. Existe uma relação geral do crescimento da concentração do cloreto diluído (meq/L) em cada aumento da concentração total $(\mu \mathrm{S} / \mathrm{cm})$ manifestada para todas as concentrações das águas subterrâneas analisadas superiores aos $1000 \mu \mathrm{S} / \mathrm{cm}$. Em virtude da correlação significativa da condutividade $(\mu \mathrm{S} / \mathrm{cm})$ com os Sólidos Totais Diluidos, STD, em mg/L, pode estender-se esta consideração, como compreensão conceitual, para uma concentração dos STD superior aos $1000 \mathrm{mg} / \mathrm{L}$.

Deve-se esclarecer que o limite da concentração total em volta aos $1000 \mathrm{mg} / \mathrm{L}$ ou $1000 \mu \mathrm{S} / \mathrm{cm}$ é muito utilizado como limite da potabilidade para o consumo humano. Todas essas normas especificam o valor recomendado (500 $\mathrm{mg} / \mathrm{L}) \mathrm{e}$ o tolerado como máximo (1000 mg/L) (Szikszay, 1993). No caso das águas minerais, o limite é estabelecido nas respectivas definições de água mineral em alguns paises (Alemanha e França entre eles). $O$ resultado aqui alcançado fundamenta este mesmo limite segundo as distintas relações e correlações demonstradas dos ânions diluídos com a concentração total para todas as águas subterrâneas analisadas. As normas de potabilidade não especificam o porque desse limite. Também não é esclarecido porque o mesmo limite define a água mineral da água subterrânea comum. Talvez este resultado permita fundamentar os argumentos intuitivos anteriores das normas estabelecidas.

Pode generalizar-se como um resumo do evidenciado com respeito ao comportamento dos ânions nas águas subterrâneas, o seguinte:

- Existem na região de estudo dois campos distintos de comportamento dos ânions na solução da água subterrânea, independentes da litologia pelas quais circulam :

1. Para a faixa de concentração total inferior aos $1000 \mathrm{mg} / \mathrm{L}$

2. Para a faixa de concentração total superior aos $1000 \mathrm{mg} / \mathrm{L}$ 

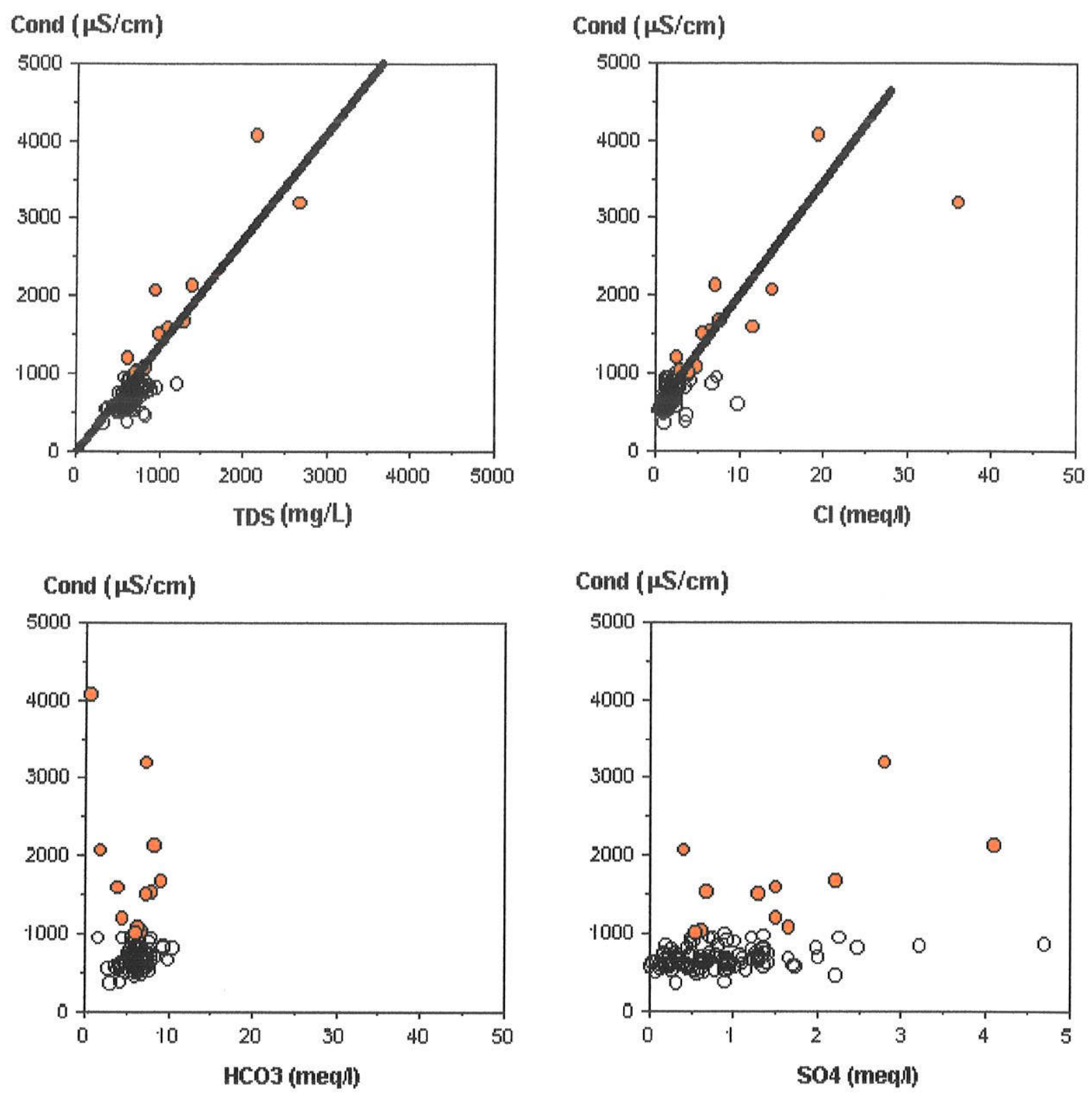

\section{Legenda :}

Condutividade $>1000 \mu$ Sicm

Tendência ou limitaçäo do comportamento dos pontos

Figura 49. Correlação gráfica dos componentes aniónicos principais em meq/L com respeito a Condutividade em $\mu \mathrm{S} / \mathrm{cm}$ nas águas subterrâneas que circulam através da Formação Ciego de Avila.

(Fonte : Rodriguez et al, 1996) 

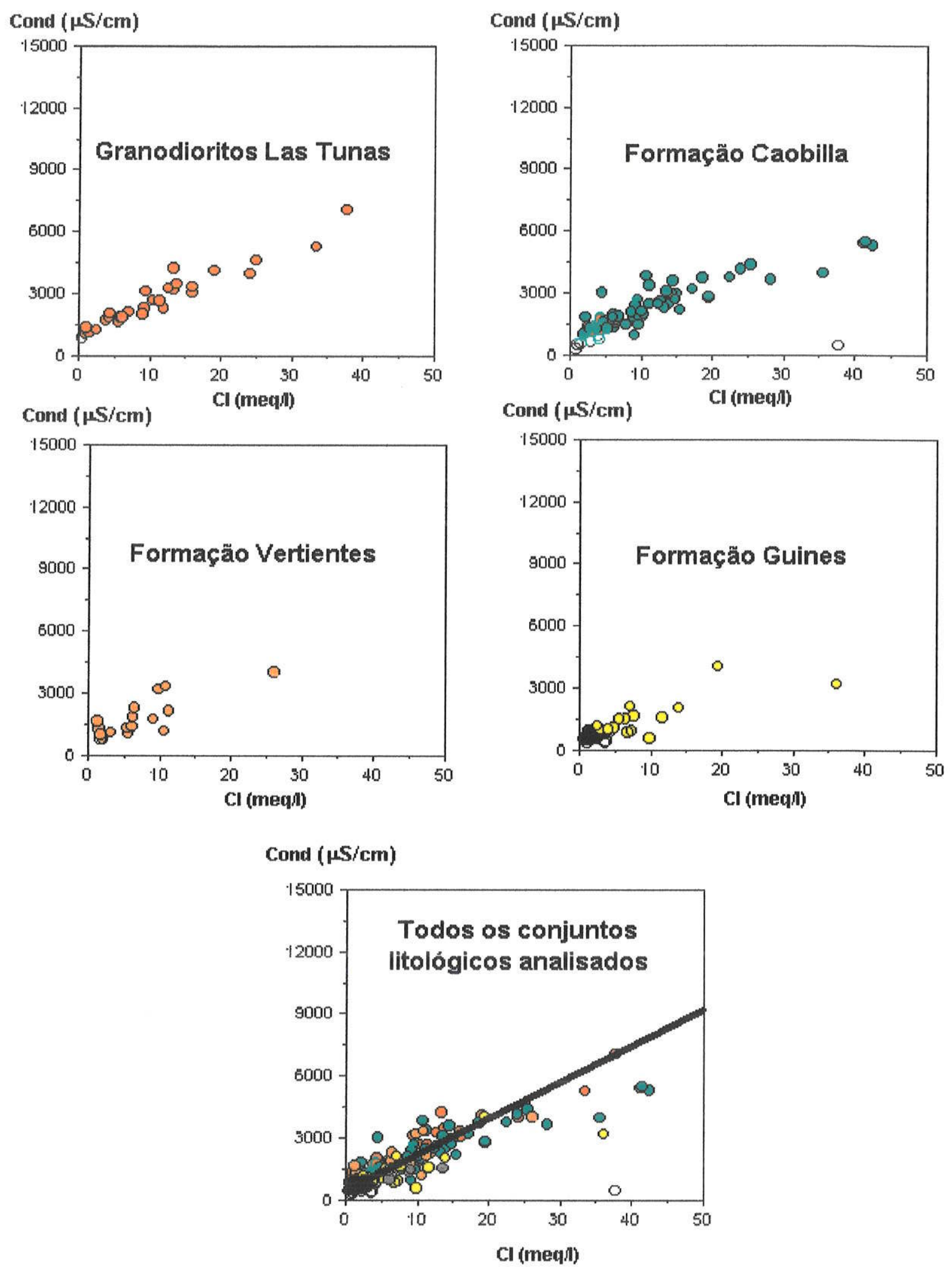

Figura 50. Comparação das similaridades das tendências lineares da correspondência Condutividade $(\mu \mathrm{S} / \mathrm{cm}) /$ Cloretos (meq/L) para os conjuntos litológicos analisados.

(Fonte : Rodriguez et al, 1996) 
No campo 1,

-Domina a linearidade da correlação do $\mathrm{HCO}_{3}$, a qual é significativa a partir dos seus valores mínimos de concentração total, perto de $0 \mathrm{mg} / \mathrm{L}$, até os $1000 \mathrm{mg} / \mathrm{L}$ de STD ou $10 \mathrm{meq} / \mathrm{L}$ de $\mathrm{HCO}_{3}$.

No campo 2,

-A correlação dos $\mathrm{HCO} 3$ já não é significativa e a sua diluição fica constante nos valores de $10 \mathrm{meq} / \mathrm{L}$ para qualquer concentração total (STD) superior aos $1000 \mathrm{mg} / \mathrm{L}$.

$-\mathrm{O} \mathrm{SO}_{4}$ bifurca seu comportamento:

. A partir de uma concentração total entre $2000-3000 \mathrm{mg} / \mathrm{L}$ e até os $12000 \mathrm{mg} / \mathrm{L}$ de STD os valores da sua concentração mantêm uma correlação linear até os 20-30 meq/L. Para valores maiores de $30 \mathrm{meq} / \mathrm{L}$ e concentração superior aos $12000 \mathrm{mg} / \mathrm{L}$ de STD, faz-se constante na solução.

-Existe uma proporcionalidade constante entre a concentração do cloreto diluido (meq/L ou $\mathrm{mg} / \mathrm{L}$ ) e a concentração total ( $\mu \mathrm{S} / \mathrm{cm}$ ou $\mathrm{mg} / \mathrm{L}$ ) da água subterrânea.

-O Cl continua sua correlação significativa até os valores máximos de concentração total dos dados utilizados da região de estudo. Sem limitações nenhumas desde o início até o fim processado. 


\section{Avaliação dos limites da estabilidade das correspondências avaliadas para o prognóstico do comportamento das águas a concentrações superiores as águas subterrâneas comuns.}

As considerações anteriores no que diz respeito do comportamento comum dos ânions principais dissolvidos nas águas subterrâneas demonstraram que apenas o cloreto continua aumentando em solução para o aumento gradual da concentração total. Demonstrar ou comprovar até onde pudesse continuar esta única correlação componente/concentração total é o alvo deste capítulo. Evidentemente, os valores de salinidade total das águas da região sob estudo resultam muito limitadas para o objetivo proposto.

Para este fim foram processadas águas subterrâneas salgadas de Israel, águas de Mares profundos e águas de reconhecida alta salinidade, marinhas e relacionadas com petróleo, obtidas da literatura internacional e cujas referências destacam-se na Tabela 8 . A ordem de análise dos dados utilizados foi das concentrações menores até as maiores reportadas.

A Figura 51 apresenta os resultados do processamento efetuado com as águas subterrâneas salgadas de Israel. Respeitou-se a nomeação do autor (Rosenthal, 1999) para os pontos selecionados, apenas numerando-se progressivamente para simplicidade da sua representação nos gráficos correspondentes.

Nenhuma das águas alcança a concentração da água do mar, mas os seus valores de concentração começam pelo mínimo das precipitações no território, até alcançar as maiores concentrações das águas subterrâneas comuns analisadas nesse território.

Pode apreciar-se no gráfico de Piper que os pontos de maior concentração deslocam-se, a partir da concentração bicarbonatada cálcica das precipitações, em direção ao quadrante direito superior devido ao peso que exerce a concentração cloretada das águas. No gráfico de Schoeller pode ver-se que as concentrações de todos os componentes das precipitações estão abaixo das concentrações das águas subterrâneas, a favor da confiabilidade dos dados $e$ do processador do programa utilizado. Nos dois gráficos analisados constatase a composição bicarbonatada das águas subterrâneas e a sua continuidade gradual até os tipos cloretados.

No gráfico de STD $(\mathrm{mg} / \mathrm{L}) / \mathrm{Cl}(\mathrm{meq} / \mathrm{L})$ aprecia-se a linearidade do aumento proporcional de um parâmetro com respeito ao outro, já para as concentrações até

os $300 \mathrm{meq} / \mathrm{L}$, do cloreto e $16000 \mathrm{mg} / \mathrm{L}$ de STD. No caso do $\mathrm{SO}_{4}$, apresentase a tendência referente à linearidade até os $30 \mathrm{meq} / \mathrm{L}$ com a exceção do comportamento das concentrações do $\mathrm{SO}_{4}$ das águas subterrâneas relacionadas com petróleo. 
Tabela 8. Referências bibliográficas das fontes dos dados utilizados nas figuras correspondentes.

\begin{tabular}{|c|c|c|c|c|}
\hline $\begin{array}{l}\text { Referência da } \\
\text { figura: }\end{array}$ & Autor & $\begin{array}{l}\text { No. da } \\
\text { Tabela }\end{array}$ & Página & Título na referência bibliográfica \\
\hline VI.21 & Rosenthal et al, 1999 & 1 & 264 & $\begin{array}{l}\text { Ground Water Salinization Caused by Residual } \\
\text { Neogene and Pliocene Sea Water-An Example } \\
\text { from the Judea Group Aquifer, Southern Israel } \\
\text { Groundwater, Vol.37, No.2, pp } 261-270\end{array}$ \\
\hline VI.22 & Schoeller, 1955 & $\mathrm{~S} / \mathrm{N}$ & 66 & 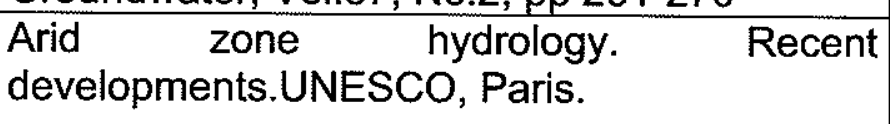 \\
\hline VI.23 & Chebotarev, 1955 & 37,39 & 159,160 & 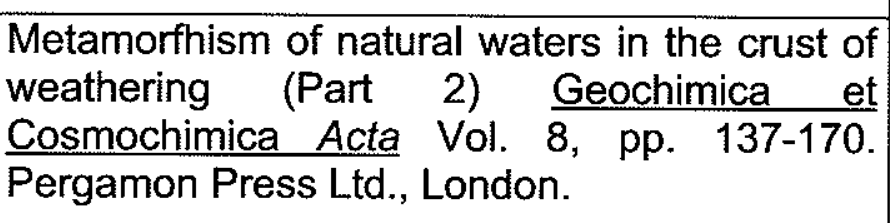 \\
\hline VI.24 & Schoeller, 1962 & $\mathrm{~S} / \mathrm{N}$ & 316,317 & $\begin{array}{l}\text { Hydrogeologie. Vol. II. Paris. Societé des } \\
\text { Editions.TECHNIP } 443 \text { p. }\end{array}$ \\
\hline VI.25 & Osler,1972 & 152 & 320 & $\begin{array}{l}\text { ROSLER, H. J. (1972) Geochemical Tables. } \\
\text { Elsevier Publishing Company, N.Y. } 750 \text { p. }\end{array}$ \\
\hline
\end{tabular}



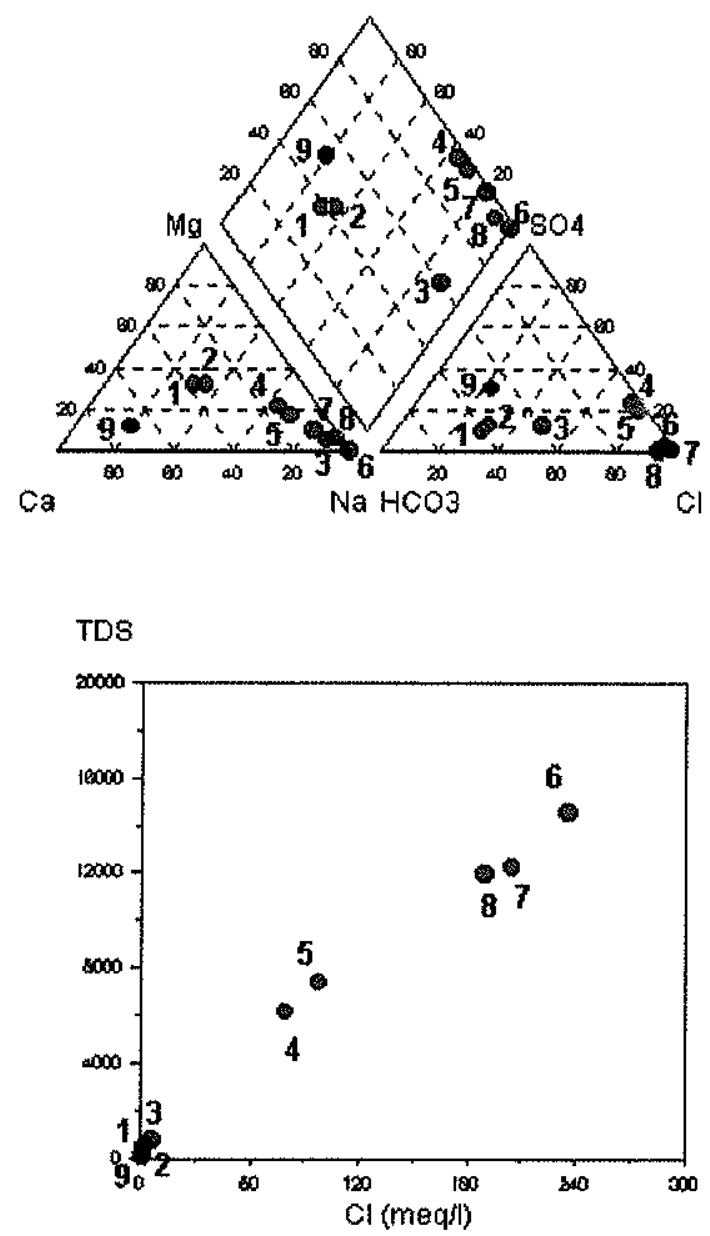

Legenda :
Concentration (mequl)

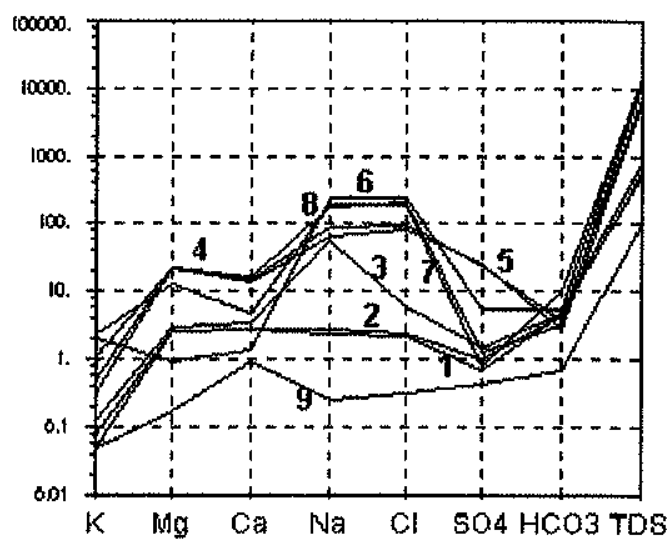

TDS

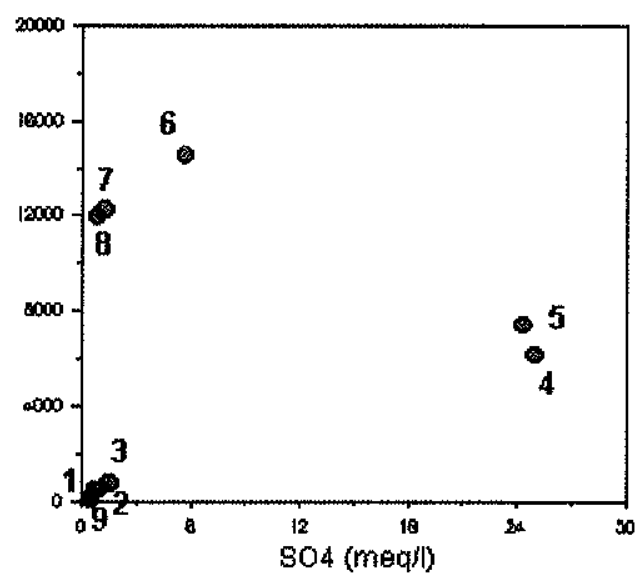
1 Amatzlyah11
4 Hazerim 1
7 Gat 1
- 2 Sheqef 1
5 Hagenev 1
8 Nebusha 1 a
3 Tel Zafit
6 Beerl 1
9 Precipitaçóes de israel
- (Bet Jemal St)
Observações :

- 1,2,3 6 agua subteranea no Judea Group

- 4,5 vem derivado do mar penetrado no plioceno por falhas

- 6,7,0 pertencem ao grupo Lahish que tem $\$ 04$ reduzido devido a de presencia de petroleo.

- Nota: nenhuma água chega à concentração do mar (STD $=36000 \mathrm{mg} / \mathrm{L}$ )

Figura 51. Gráficos que apresentam o comportamento dos componentes principais de uma seleção das águas subterrâneas salgadas de Israel. Relacionam-se neles a concentração das precipitações particulares do território.

(Fonte : Vide Tabela 8) 
A Figura 52 apresenta o resultado nos mesmos gráficos para águas de alta salinidade para os casos de águas concentradas por evaporação e por dissolução (Schoeller, 1955).

Note-se que as águas em análise estão numa ordem muito superior às águas do mar (considerada em média, por volta dos $36000 \mathrm{mg} / \mathrm{L}$ de STD). Ainda com estes valores de alta salinidade, pode-se notar: 1) no gráfico Piper a tendência é o deslocamento do tipo de água ao quadrante direito, do mesmo jeito que as águas do caso anterior, mais salinizadas que as águas subterrâneas da região de estudo e menos que a do mar. 2) No gráfico de Schoeller a configuração geral é de água $\mathrm{Na}-\mathrm{Cl}$. 3) No gráfico $\mathrm{STD} / \mathrm{Cl}$ aprecia-se nitidamente a continuação da sua correlação para altos valores de STD, que chegam até os $320000 \mathrm{mg} / \mathrm{L}$. Nota-se, também, que a concentração do $\mathrm{Cl}$ das águas de alta salinidade, é mantida à mesma linearidade, onde as provenientes da evaporação estão por abaixo das concentradas por diluição. 4) No caso dos $\mathrm{SO}_{4}$ os altos valores da concentração não parecem estabelecer comportamento nem tendência nenhuma com os seus baixos valores.

Considerando que o outro grupo de águas subterrâneas são aquelas relacionadas com as jazidas de petróleo, analisou-se o que acontece nestes casos. A Figura 53 apresenta águas de salmouras relacionadas com depósitos de petróleo (Chebotariev, 1955).

No gráfico de Piper observa-se que as águas de alta concentração mantêm-se no vértice direito dos ânions, $\mathrm{Na}-\mathrm{Cl}$, ocupando o quadrante direito, não no mesmo vértice devido a influencia dos componentes de cálcio presentes, evidentes no gráfico de Schoeller.

Aprecia-se mais uma vez, que a concentração dos cloretos continua alinhada com uma correlação significativa para estes altos valores da concentração total dos STD (superior aos $400000 \mathrm{mg} / \mathrm{L}$ ). No caso dos $\mathrm{SO}_{4}$ aparece alguma linearidade sem aparente regularidade estimável.

A Figura 54 apresenta um outro grupo de águas de alta salinidade relacionadas também com petróleo (Schoeller, 1962), as quais a referência cita a sua vinculação direta com estas jazidas.

No gráfico de Piper dessa figura pode ser visto, mais uma vez, como estes tipos de águas concentram-se nos extremos das águas cloretadas sódicas, se comparadas com o gráfico de Schoeller. Nota-se, aliás, o enriquecimento em cálcio, distintivo das águas representativas das jazidas de Borislaw, Polônia.

No referente ao $\mathrm{SO}_{4}$ diluído, não parece existir alguma evidência de regularidade, a exceção dos baixos valores, inferiores a $5 \mathrm{meq} / \mathrm{L}$. 

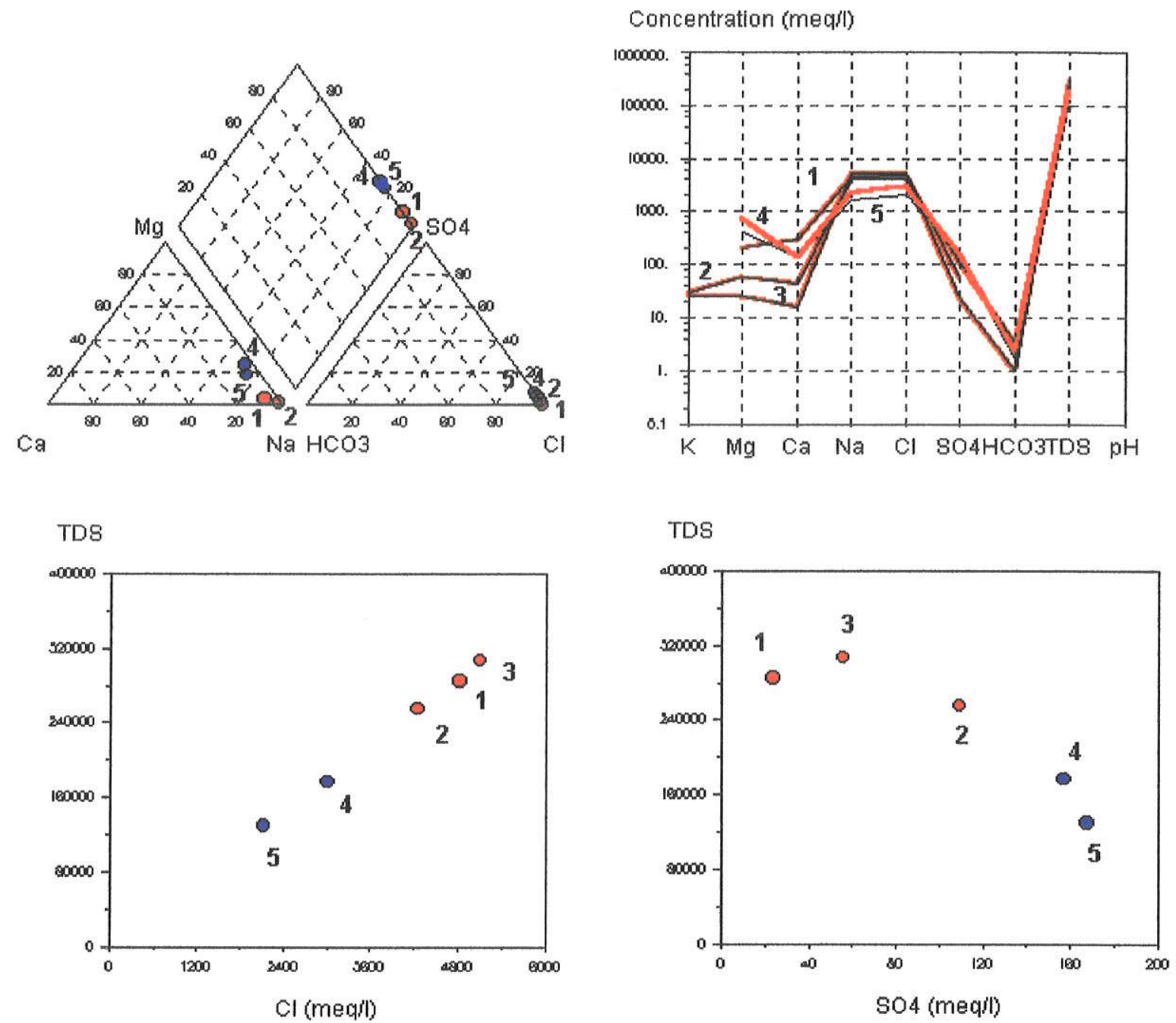

\section{Legenda :}

- Águas concentradas por dissolução

1 Saline Spring, 1 km, south of Douira, near Ain Rahlad, Tunisia

2 Source Bayaa, of Salies-de-Béarn, France

3 Source de Briscous, near Biarritz, France

Águas concentradas por evaporação

4 Sebbka west of Kredma el Kebira, Tunisia

5 Kredma el Kebira, Sebbka, Tunisia

Figura 52. Gráficos que apresentam o comportamento dos componentes principais de uma seleção das águas subterrâneas de reconhecida alta salinidade.

(Fonte : Vide Tabela 8) 


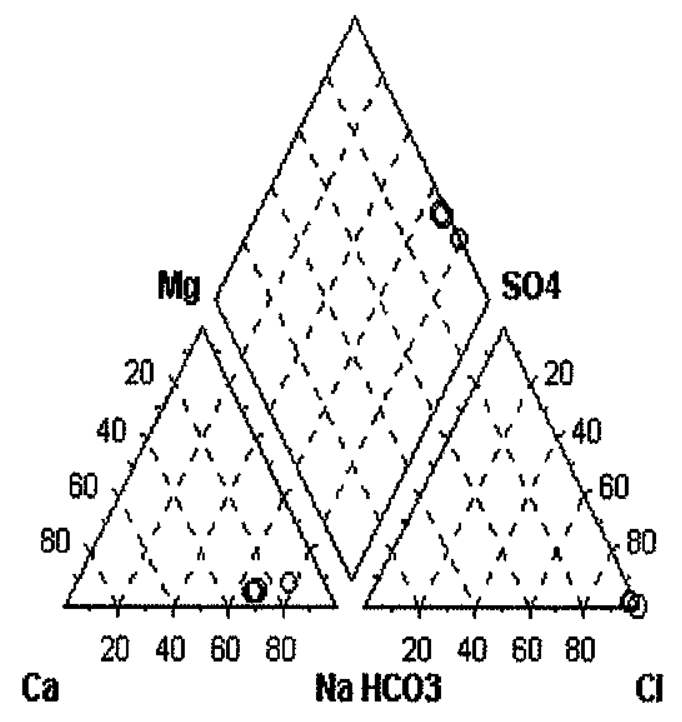

\section{Concentration (imual)}

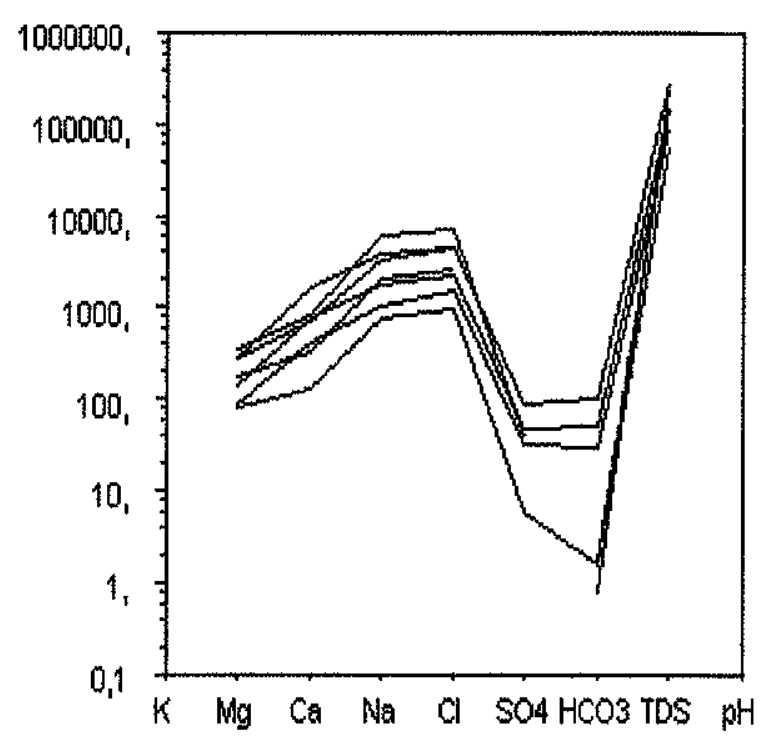

TDS
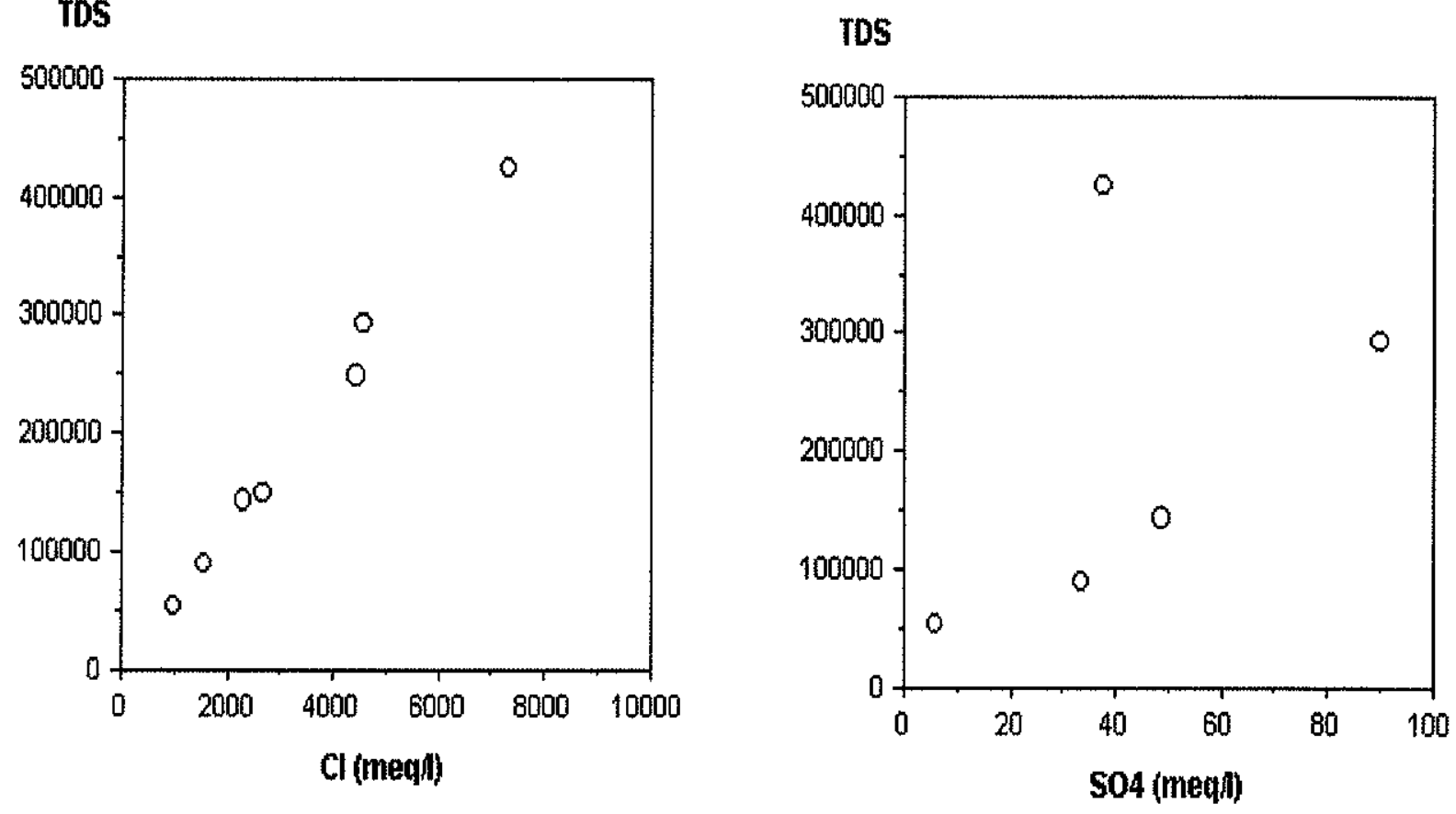

Figura 53. Gráficos que apresentam o comportamento dos componentes principais de uma seleção das águas de salmouras relacionadas com depósitos de petróleo.

(Fonte: Vide Tabela 8) 

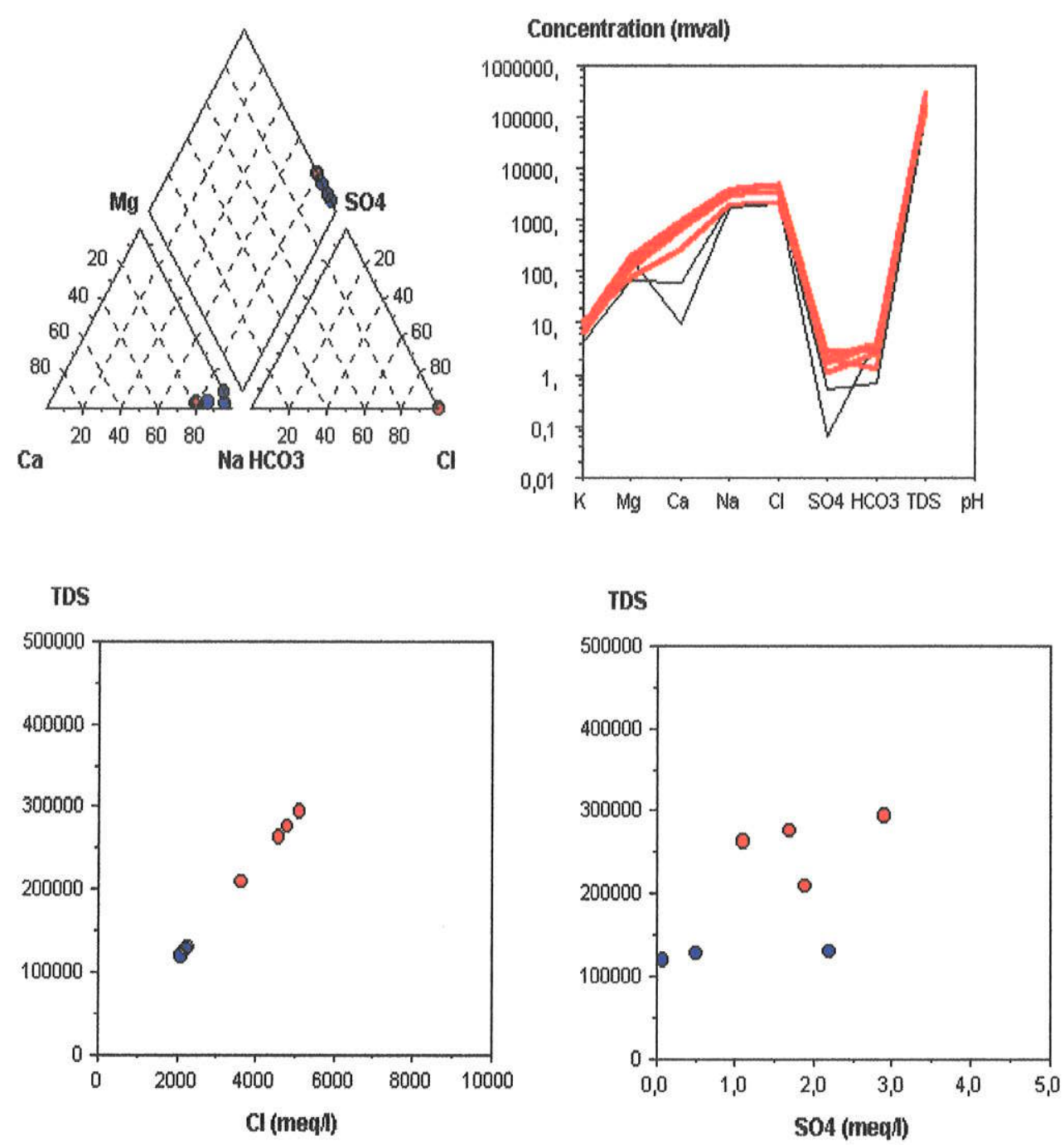

\section{Legenda :}

- Águas relacionadas com petrôleo de jazidas da Rumênia

- Águas relacionadas com petrôleo de campos petroliferos da Polônia

Figura 54. Gráficos que apresentam o comportamento dos componentes principais de uma seleção das águas vinculadas com jazidas de petróleo.

(Fonte : Vide Tabela 8) 
A análise efetuada destas águas evidencia que entre os ânions nelas dissolvidos, em qualquer concentração, o cloreto é o único que não abandona a solução e o único, também, que mantém uma proporcionalidade constante vinculada com 0 aumento da concentração, enquanto os bicarbonatos $e$ sulfatos perdem estas correspondências logo aos $1000 \mathrm{mg} / \mathrm{L}$ de STD para os primeiros e aos $12000 \mathrm{mg} / \mathrm{L}$ de STD para os segundos, o mesmo evidenciado para a região de estudo.

Pela mesma ordem de raciocínio utilizada, resulta evidenciada que a vinculação da composição aniônica das águas com a sua gênese, começa a ser desarticulada a partir dos $1000 \mathrm{mg} / \mathrm{L}$ de STD, a partir dos quais a predominância do ânion cloreto faz-se comum para qualquer procedência das águas. Evidencia-se que neste campo acima dos $1000 \mathrm{mg} / \mathrm{L}$ de STD, a solução não só se enriquece com cloretos, senão que se especializam os comportamentos de cada um dos ânions dentro da solução. Os bicarbonatos permanecem constantes, os sulfatos mantêm alguma proporcionalidade dentro da solução para uma determinada faixa inferior aos $12000 \mathrm{mg} / \mathrm{L}$ de STD ou permanecem constante inferior aos $200 \mathrm{meq} / \mathrm{L}$, e, o cloreto, permanece constantemente proporcional com o aumento da concentração até o valor máximo.

A Figura 55, que agrupa todas as águas analisadas neste item (Figuras 51, 52, 53 e 54), exemplifica o que acontece às águas subterrâneas no universo da alta salinidade, que representa a sua vez, a continuidade do comportamento dos ânions das águas subterrâneas comuns ou de baixa salinidade (menor dos $1000 \mathrm{mg} / \mathrm{L}$ de STD), analisadas ao princípio.

A proporcionalidade como se manifesta o aumento da concentração do cloreto com o aumento da concentração total das águas subterrâneas, comum para todas as concentrações do ânion cloreto, faz deduzir a existência de um processo hidrogeoquímico muito específico, até a atualidade nunca demonstrado nem evidenciado. É um processo no qual parecem agir leis físicoquímicas particulares à solução água num campo de ação contínuo que o fazem imperturbável e invariável no sentido do aumento da concentração. Denominamos este processo de Cloretogênese. A denominação assumida é devida ao crescente aumento da concentração de cloreto, contraditório com a possibilidade de fontes que justifiquem a sua abundância em qualquer profundidade.

Este processo age nas águas subterrâneas a partir de qualquer tipo de água subterrânea e num só sentido, em direção a sua concentração total, final. $O$ final do processo deve acontecer quando a concentração das águas subterrâneas se equilibra com as condicionantes físico-químicas das rochas circundantes na profundidade alcançada. Resulta, então, que o processo não é detido, senão paralisado dinamicamente até que alguma mudança do entorno possa reativar-lo. 
TDS
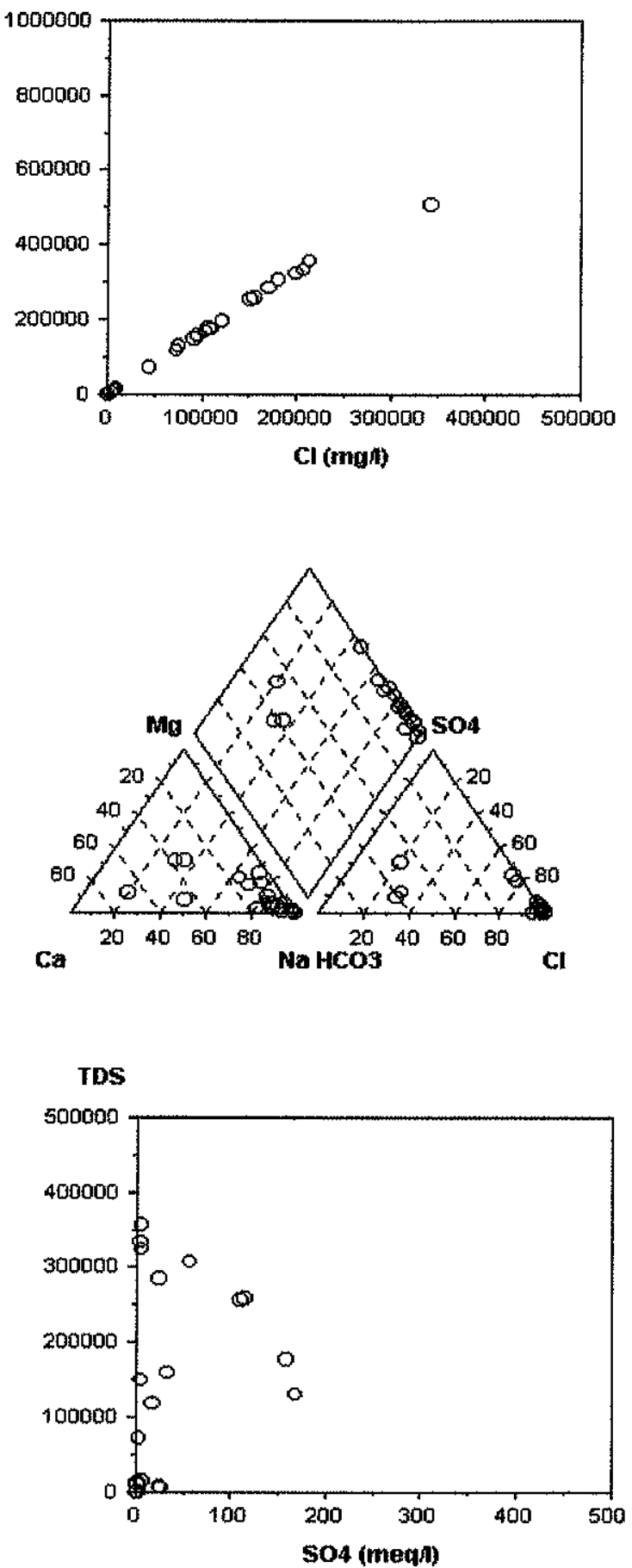

TDS

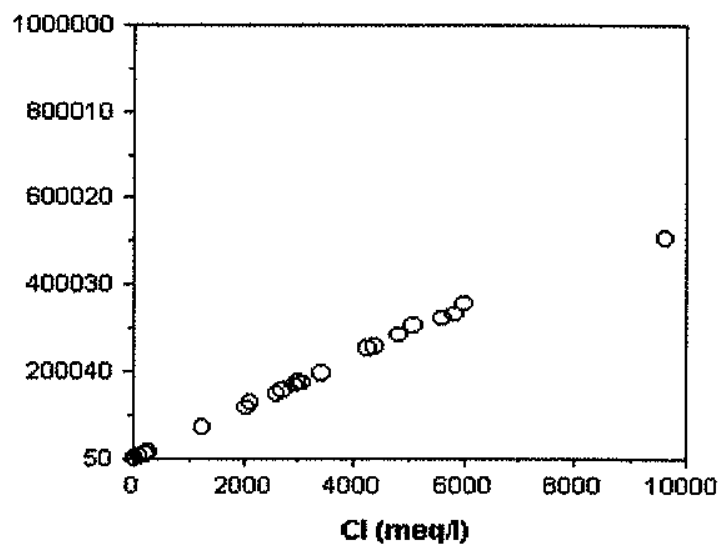

Concentration (maal)
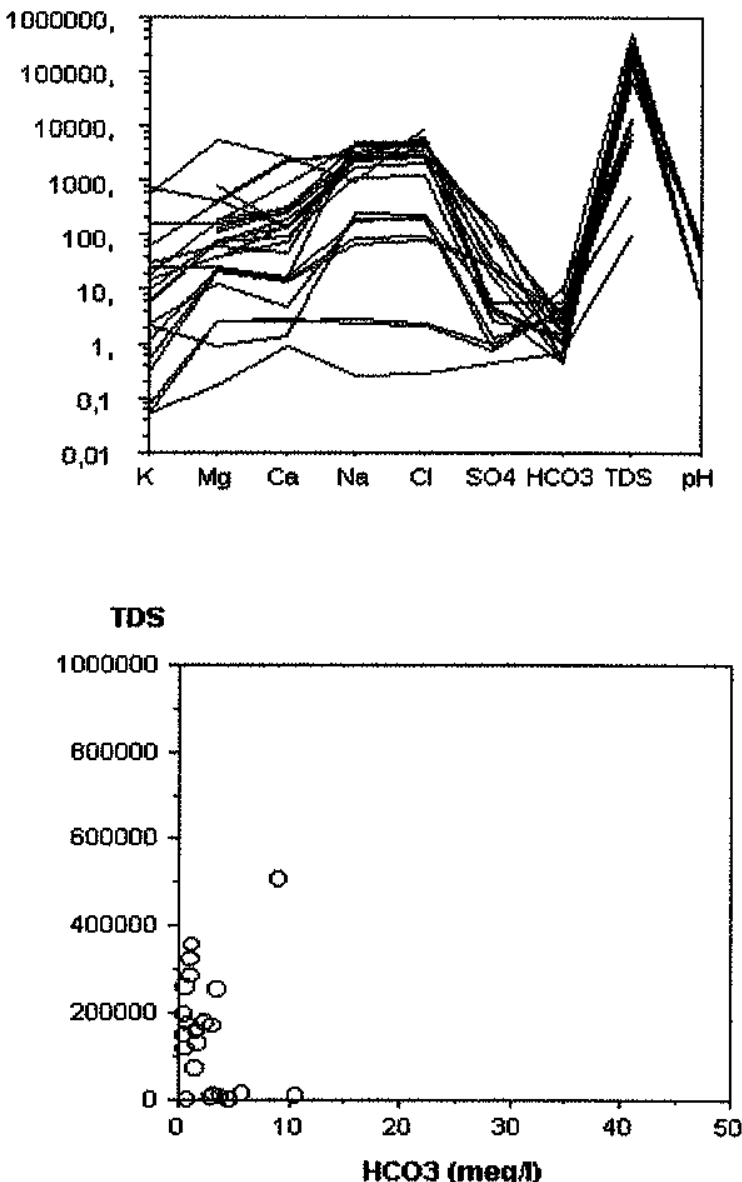

Figura 55. Gráficos que resumem a análise do comportamento dos ânions nas águas de alta salinidade.

(Vide Tabela 8 e Figuras 51, 52, 53 e 54) 


\section{Considerações derivadas do processo da cloretogênese.} Fundamentação de um novo método de datação de idades das águas

O resultado da existência de um processo de caráter universal dentro do domínio do comportamento dos ânions nas águas subterrâneas, representado através do cloreto, mudou um pouco a estrutura da concepção inicial da presente pesquisa, porque o próprio processo da Cloretogênese transforma o enfoque tradicional hidrogeoquímico até hoje utilizado. Por isso, o presente capítulo, fundamentará as conceições hidrogeoquímicas que serão aplicadas para a análise da região de estudo e o modelo de circulação.

As considerações precedentes, por quanto a literatura especializada não chegou nunca a entrar até estas extensões do comportamento dos ânions na solução água subterrânea, abrem um outro caminho à interpretação hidrogeoquímica do processo que opera o enriquecimento da sua composição. Schoeller, 1962, sublinha que a concentração em cloretos é de explicação difícil ("La concentration en chlorures est alors d'explication difficile"); Drever,1988, exprime a incerteza em determinar a fonte de cloretos nas águas dos rios ("... reflet the uncertainty in assigning a source for the chloride in river waters.") e Andrews, 1996, considera que no diz ao respeito da existência do cloreto, que outros processos diferentes à concentração por evaporação devem estar acontecendo. Em geral, todos concordam que as águas de maior concentração são cloretadas sódicas e pouco se falava sobre detalhes referentes às origens (águas conatas, estancadas, etc). A concepção mais detalhada tratava os distintos tipos químicos de águas subterrâneas existentes (bicarbonatadas, sulfatadas e cloretadas) como de separadas e diferentes procedências e a sua presença relacionada com a profundidade. Nunca, a formação dos tipos químicos, como se evidencia neste trabalho, foi tratada como um processo natural contínuo que começa nas concentrações das águas de chuvas e termina quando não pode mais se concentrar.

Chebotarev, 1955, é o autor que melhor tratou de exprimir a variação do quimismo das águas subterrâneas dentro do contexto geológico como um processo global através da sua conceituação do metamorfismo das águas naturais. Simplesmente, faltou-Ihe evidenciar, porque o método de análise assumido por ele para processar o seu volume de dados foi a "análise matemático e a frequêencia integral de curvas", a evolução da concentração gradual e constante do cloreto para qualquer um tipo de origem das águas, através do correspondente gráfico ânions/concentração total, que foi o método de análise utilizado na presente pesquisa.

O afirmado neste trabalho não contradiz nenhum aspecto dos critérios hidrogeoquímicos estabelecidos na literatura especializada, desde Schoeller e Chebotarev até o presente. Apenas orienta uma visão diferente daquela até hoje concebida para interpretar o processo da formação química das águas subterrâneas, enquanto permite afirmar, em sentido geral: 1) que a possibilidade de determinar a procedência da água está apenas nos primeiros $1000 \mathrm{mg} / \mathrm{L}$ da concentração total; 2) que a presença das águas cloretadas não respondem sempre a proximidade de intrusão marinha nem depósitos de halita; 
3) que águas de alta concentração de cloreto não sempre procedem de águas marinhas aprisionadas nem de águas conatas; 4) que em qualquer território emergido existem condicionantes para localizar águas de maior concentração; 5) que a coexistência na superfície do território de fontes de águas de maior concentração perto de outras de menor concentração, indicam que as primeiras estão ascendendo de maior profundidades, como resultado das condições hidrogeológicas locais. Não resulta impróprio especificar que as afirmações anteriores podem ser questionadas ante as evidências certas de determinadas extensões de rochas de altas solubilidades de um componente químico específico como podem ser as jazidas de minerais polimetálicos, solos salinizados, estratos argilosos de baixa permeabilidade e aqüíferos kársticos costeiros.

Mas, este processo da Cloretogênese, concebido em geral como uma via de análise, permite também outras derivações e implicações processuais.

O fato de nos encontrar diante de um processo num só sentido, medível na sua progressão através de um enriquecimento gradual da sua concentração, e comum a todas as águas subterrâneas, independentes da condição e lugar de origem, faz fundamentar a possibilidade de relacionar-o com o tempo que o mesmo age.

Se este processo se manifestar comum a todas as águas subterrâneas, independente às causas locais ou regionais iniciais, o mesmo deve ter, também, uma duração similar para exprimir a sua ação em qualquer um intervalo, considerado como etapas temporais entre diferentes concentrações do cloreto diluído nas águas analisadas.

Se este conceito for certo, águas de diferentes concentrações de cloreto deveriam corresponder com águas de diferentes idades de existência de circulação, pois representam diferentes etapas de um mesmo processo. A Figura 56 apresenta gráficos de $\mathrm{Cl}(\mathrm{mg} / \mathrm{L})$ de um conjunto de águas referidas a sua localização em litologias com idades estratigráficas específicas conhecidas. Para poder relacionar entre si num gráfico estes fatores, transformou-se a idade estratigráfica a seu valor em milhões de anos de tempo geológico. Devido a informação estratigráfica abranger uma ampla faixa dos anos do tempo geológico, processaram-se dois gráficos: o primeiro para o limite inferior da escala estratigráfica e o segundo para o limite superior. Foram adicionadas aos gráficos as referencias das concentrações mínimas conhecidas das precipitações médias de Cuba e Israel, assumidas como tempo geológico zero, como condicionante inicial.

Ve-se na figura que as diferentes concentrações de cloreto mantém uma evidente correlação com as correspondentes idades de cada concentração, evidenciando que o processo da cloretogênese responde também a um valor temporal. 
Tempo

Geológico (MA)

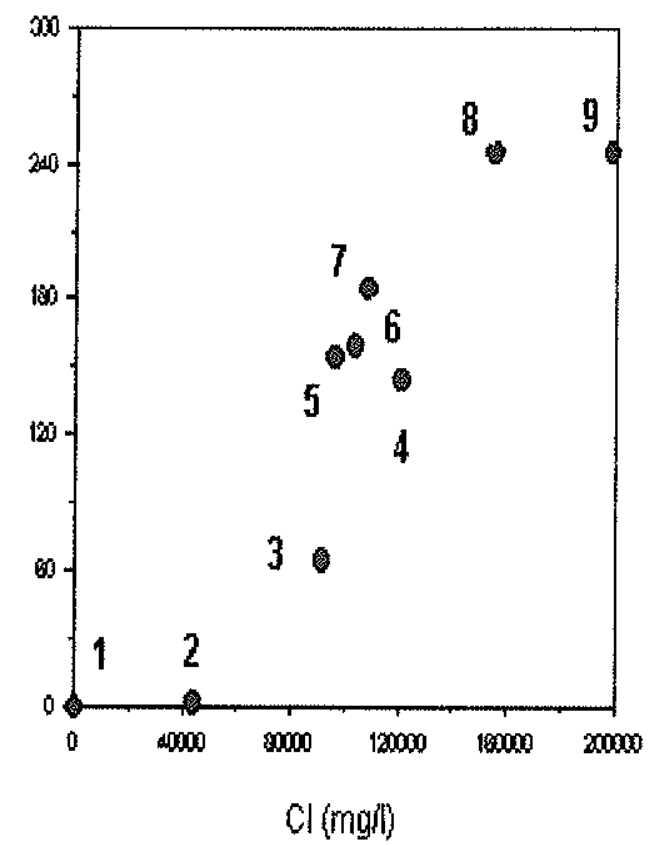

\section{Legenda :}

1 Precipitações (Cuba e lsrael)

2 S.W. Mecklenburg (Cenozoico)

3 S.W. Mecklenburg (Cretácico Superior)

4 W. Altmark (Kimmeridgiano)

5 S.W. Mecklenburg (0xfordiano)

\section{Tempo}

Geológico (MA)

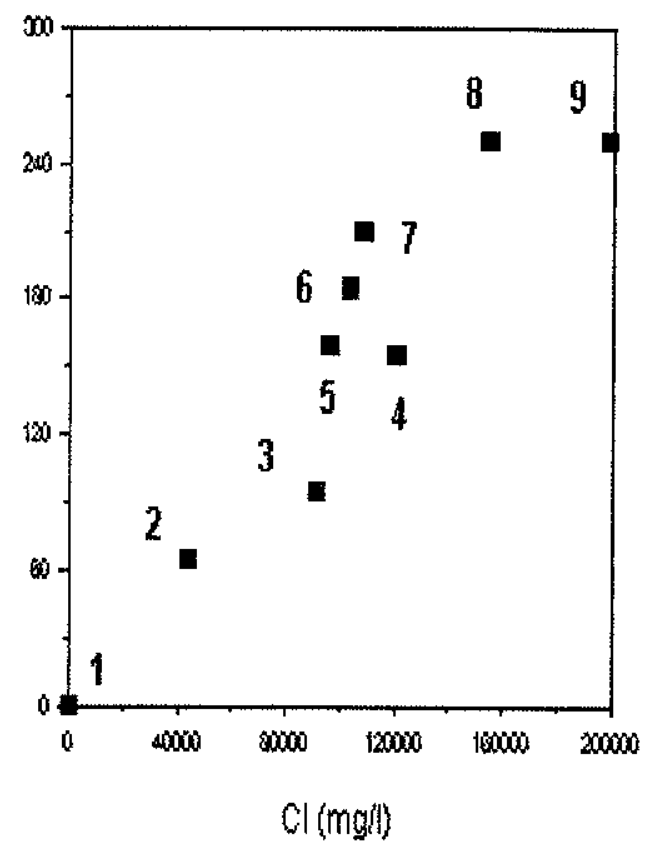

6 W. Altmark (Dogger epsilon)

7 W. Altmark (Liásico)

8 Alimenhausen (Buntsandstein)

9 S.W. Mecklenburg (Buntsandstein)

Valores minimos na faixa da idade estratigráfica

Valores máximos na faixa da idade estratigráfica

Figura 56. Relação das concentrações de cloretos em águas vinculadas com litologias de idades estratigráficas conhecidas.

(Cuba e Israel foram incorporados pelo autor)

(Fonte: Osler, 1972) 
Para avaliar se a aparente correlação existe matematicamente, procedeu-se à análise dos mesmos valores em dois programas computacionais distintos, o EXCEL e outro elaborado no Instituto de Geociências, IGc, pelo Dr. Kazu Yamamoto.

A Figura 57 apresenta os processamentos efetuados pelo programa do IGC para os ambos os casos da concentração do cloreto com respeito aos dois extremos do valor das idades estratigráficas. O gráfico superior é com respeito aos valores mínimos e o inferior aos valores máximos da faixa de idades. Aparece nos ambos gráficos a equação do coeficiente de determinação, de 0,836 para os valores mínimos e de 0,915 para os valores máximos. Como o coeficiente de correlação é a raiz quadrada do coeficiente de determinação, são obtidos valores significativos da correlação de 0,914 e 0,956 respectivamente. Resulta evidente que para os valores máximos a correlação $\mathrm{Cl}(\mathrm{mg} / \mathrm{L}) / \mathrm{T}$ empo Geológico (Ma) é mais significativa.

A Figura 58 apresenta o mesmo processamento, só para a faixa dos valores máximos, através do programa EXCEL. Pode notar-se uma correlação também significativa, ainda que com valores menores, mas que com o resultado do processamento anterior, pode ser considerada admissivel.

No que diz respeito às equações que representam as correlações, é notável as diferenças entre elas. $O$ autor seleciona a representada por EXCEL, considerando a similaridade com a equação do segundo gráfico $(0,001 \mathrm{X})$ e depreciando o argumento $(+6,209)$, pois os valores que operarão a equação serão da ordem dos milhões de anos.

Finalmente, como resultado destas avaliações, chega-se à equação que quantifica os anos de existência geológica das águas subterrâneas em função da concentração do ânion cloreto:

$$
\mathrm{T}=0,0015[\mathrm{Cl}]
$$

\section{Idade das águas subterrâneas $(\mathrm{Ma})=0,0015$ [Concentração do ânion cloreto $(\mathrm{mg} / \mathrm{L})]$}

Obtém-se assim o Método da Concentração do Cloreto para a datação das águas subterrâneas

Pelo método dedutivo utilizado na base de um empirismo total, esta relação exprime que o tempo transcorrido (em milhões de anos) desde que as águas começam formar a sua constituição química a partir das chuvas, até o ponto de análise, é função direta da concentração de cloreto alcançada (em $\mathrm{mg} / \mathrm{L})$. As causas e intensidades dos condicionantes que operam a regularidade deste processo estão implícitas no fator $0,0015$. 

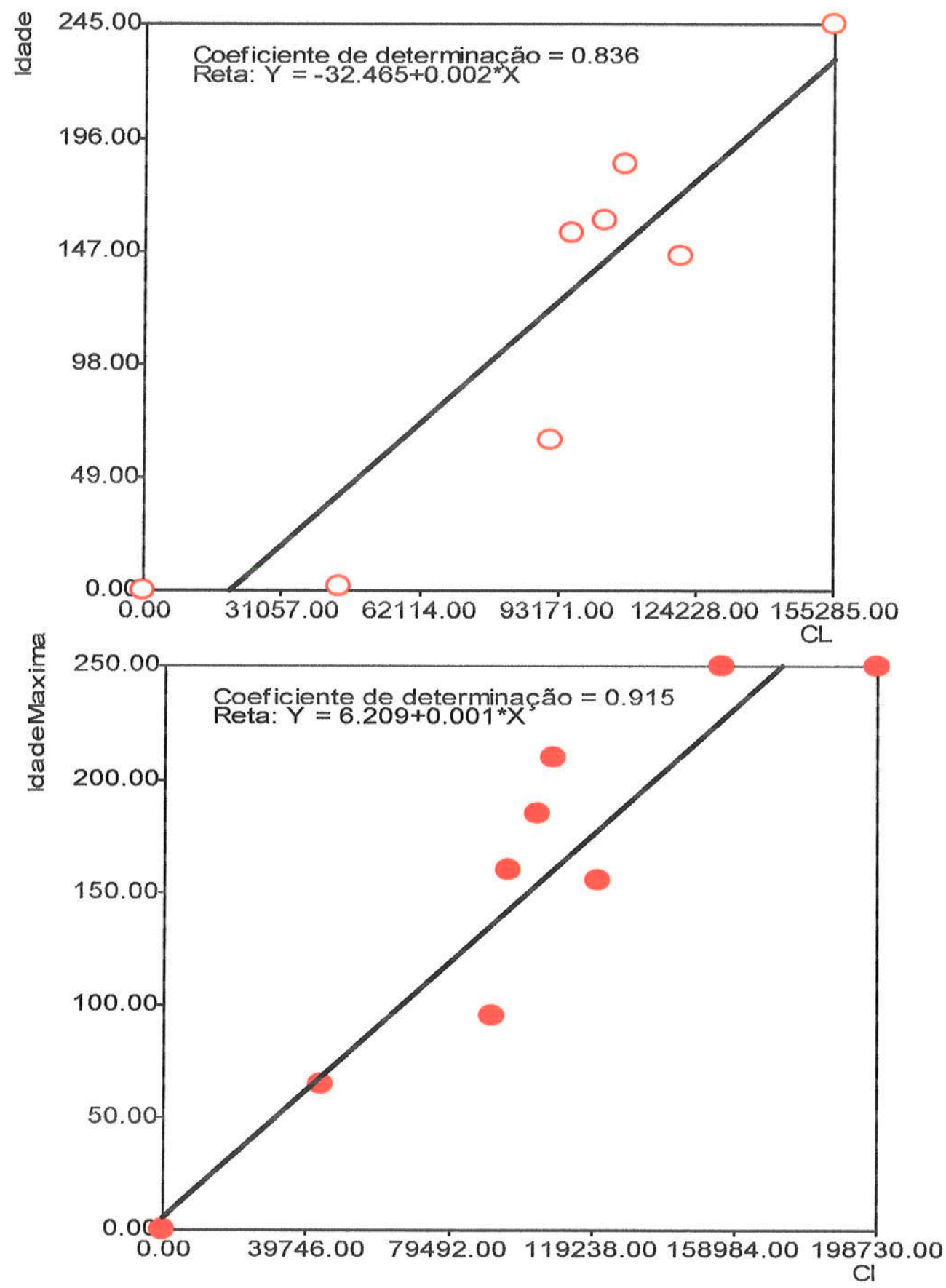

Figura 57. Gráficos que relacionam a concentração do ânion cloreto ( $\mathrm{mg} / \mathrm{L})$ das águas subterrâneas com os valores das idades estratigráficas (em milhões de anos) das litologias pelas quais circulam. O gráfico superior para o valor mínimo do intervalo estratigráfico e o gráfico inferior, para o valor máximo. 


\section{Correlação entre Tempo Geológico(milhoes de anos) e concentração de anion Cloreto(mg/L)}

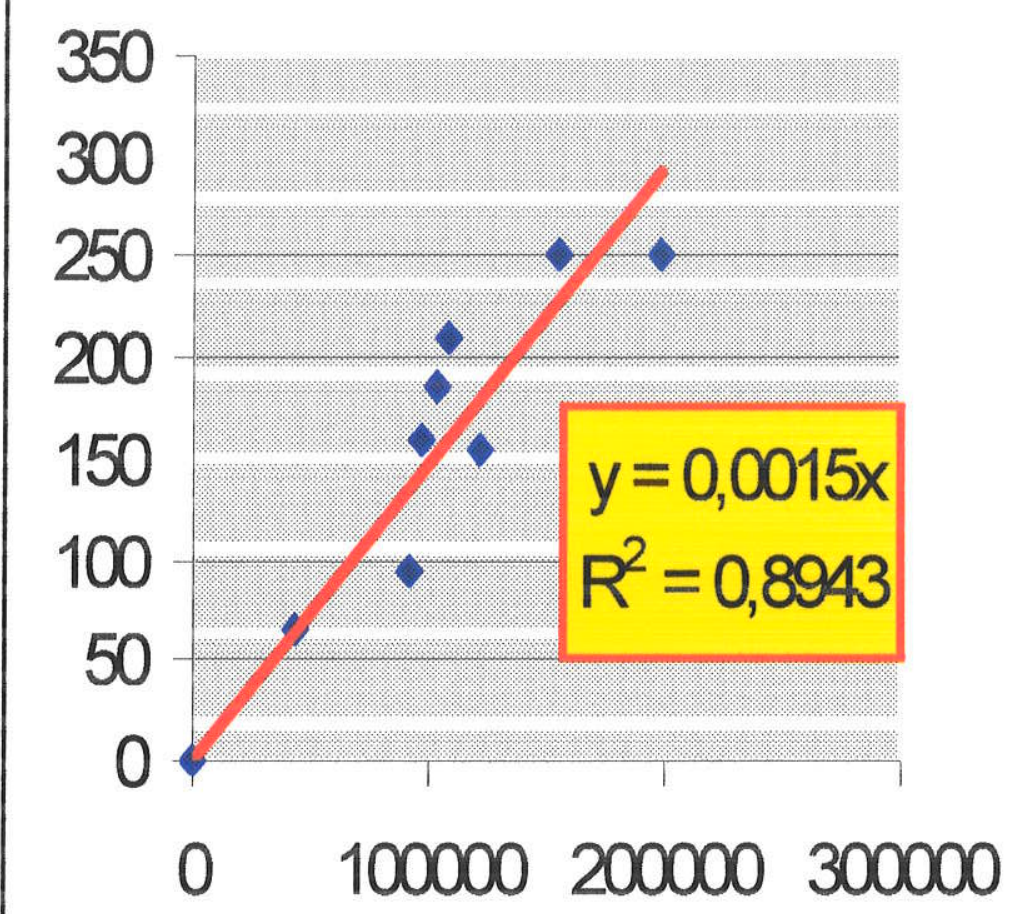

Figura 58 Correlação calculada pelo Programa EXCEL entre o Tempo Geológico em milhões de anos (eixo y) e a concentração do ânion Cloreto em $\mathrm{mg} / \mathrm{L}$ (eixo $\mathrm{x}$ ) nas águas altamente salinizadas e estratigraficamente datadas. 
Com a finalidade de verificar a credibilidade da correlação obtida, 0,956 , procedeu-se a calcular o teste de correlação ou T "Student" (Davis, 1986) para o limite estabelecido de $t>1,86$, correspondente com 7 graus de liberdade $e$ $10 \%$ do nível de significância. O valor final obtido de 8,37 avalia que a correlação é significativa e, por isso, aplicável.

O fato que matematicamente o significado da equação seja convincente, ainda não avalia a credibilidade da relação estabelecida. Por isso, compararam-se os valores já calculados na literatura com os mesmos calculados pelo presente método.

Em sentido geral, na literatura internacional não abunda muito o questionamento aos métodos existentes de datação de idades e, muito menos à conceituação da idade das águas, porquanto também não existem referências sobre os valores do tempo das águas consideradas de jovens nem de velhas. $O$ acordo comum é que a idade das águas subterrâneas é o tempo transcorrido até a profundidade de captação, após infiltração, com a exceção declarada de que "não necessariamente duas moléculas de água da mesma amostra devem ter a mesma idade" (Bentley, 1986), o que fundamenta o conceito mais apropriado, que o autor compactua, de "idade média das águas subterrâneas" ("average"groundwater age). Mas, o valor do conceito ainda não esta muito bem definido, nem sequer declarado o entorno ou faixa do valor do tempo para as águas jovens ou velhas.

Os métodos isotópicos, os mais utilizados, tem sido de alta valia para descriminar as águas de mais recente infiltração em relação com outras circundantes (idade relacionada, não quantificada) ou a zona de recarga para precisar a direção do fluxo subterrâneo, todas em escala local, entre os principais usos. A possibilidade de não poder justificar a comparação das diferentes gêneses das águas numa escala regional, impossibilitam nestes métodos, à comparação das "idades relativas" entre regiões diferentes e longes entre si, tanto mais enquanto abranja aos dois hemisférios.

O Método do carbono $14\left({ }^{14} \mathrm{C}\right)$, o mais estudado, está limitado a uma determinação inferior aos 80000 anos, muito custoso como para ser utilizado regularmente, o que justifica não poder saber da existência ou não de idades das águas subterrâneas superior a estes valores. Bentley, 1986, chega alcançar os valores até 1-2 milhões de anos aplicando o Método do ${ }^{36} \mathrm{Cl}$, especificando os inconvenientes da sua efetividade, a causa dos parâmetros a assumir, e da sua aplicabilidade, pelos custos altos da tecnologia necessária e precisão da amostragem.

Esta situação tem originado pouca possibilidade de comparação da certeza do dado obtido e por isso também não da apreciação da precisão do entorno do erro dos resultados entre os métodos. A comparação mais comum tem sido a comparação com o Método Hidrodinâmico, que baseia os seus cálculos na velocidade do fluxo subterrâneo, gradiente hidráulico e os parâmetros do meio da 
circulação, que evidentemente, para grandes longitudes e complexidades hidrogeológicas, tais fatores viram bastante fortuitos e aleatórios.

No obstante, o autor considerou necessário avaliar o método fundamentado com as cifras até hoje obtidas pelos métodos em uso. A Tabela 9 apresenta os resultados dos métodos em comparação, para aqueles pontos que contavam com a concentração de cloreto determinada, selecionados nos dois trabalhos que reuniam a todos os métodos anteriores e que alcançava até os valores superiores ao milhão de anos (Bentley et al, 1986; Phillips et al, 1986). Pode apreciar-se na Tabela 9 que o entorno do erro entre todos não da credibilidade a nenhum método, que justifica, também, uma discrepância similar dos dois métodos comparados com o da Concentração do Cloreto.

Para precisar a tendência dos erros entre os métodos de ${ }^{36} \mathrm{Cl}$ e Hidrodinâmico com o proposto pelo autor, elaboraram-se os gráficos da Figura 59. Pode apreciar-se nos gráficos, que os erros $<10-20 \%$ (aceitável, considerando a ordem dos vários milhares e milhões de anos das cifras implicadas) tendem a ser menores para os 1-2 milhões de anos para ambos os métodos o que permite concluir na credibilidade do método fundamentado neste trabalho. $O$ fato da redução comum dos erros nesta faixa das idades dos milhões de anos permite também, considerando a linha dedutiva que o fundamentou, supor credibilidade similar na ordem dos valores inferiores ao milhão de anos.

Muitas considerações faltam ainda por serem abordadas e abrem o caminho a outras especulações e deduções enquanto aos conceitos de tempo das águas e a sua aplicação à análise da região de estudo, que serão abordadas nos próximos capítulos, até fundamentar com este novo enfoque, o modelo hidrogeoquímico de circulação das águas subterrâneas na área de estudo. 
Tabela 9. Comparação das idades das águas através dos métodos atuais com o Método da Concentração de Cloreto.

\begin{tabular}{|c|c|c|c|c|c|c|c|}
\hline \multirow[t]{2}{*}{$\begin{array}{l}\text { No. Ponto } \\
\text { em } \\
\text { referência }\end{array}$} & \multirow[t]{2}{*}{$\underset{(\mathrm{mg} / \mathrm{L})}{[\mathrm{Cl}]}$} & \multicolumn{3}{|c|}{$\begin{array}{c}\text { Método de Datação de águas } \\
\text { utilizado (anos) }\end{array}$} & \multicolumn{2}{|c|}{$\begin{array}{l}\text { Avaliação do erro com } \\
\text { respeito ao Método da } \\
\text { Concentração do Cloreto }\end{array}$} & \multirow[b]{2}{*}{ Fonte } \\
\hline & & Cloreto 36 & Hidrodinâmico & $\begin{array}{c}\text { Concentração } \\
\text { do Cloreto }\end{array}$ & $\begin{array}{l}\text { Cloreto } 39 / \\
\text { Concentraçăo do } \\
\text { Cloreto }\end{array}$ & $\begin{array}{l}\text { Hidrodinâmicol } \\
\text { Concentração do } \\
\text { Cloreto }\end{array}$ & \\
\hline 305 & 187 & 1200000 & 280000 & 187000 & 0.332 & 0.084 & \multirow{6}{*}{$\begin{array}{l}\text { Tabela 1, pag. 1997. BENTLEY, H, W ; } \\
\text { PHILLIPS, F. M. ; DAVIS, S. N. ; } \\
\text { HABERMEHL, M. A ; AIREY, P. L. ; } \\
\text { CALF, G. E. ; ELMORE, D. ; GOVE, H. E. } \\
\text {; TORGERSEN, T. (1985) }\end{array}$} \\
\hline 1184 & 167 & 900000 & 230000 & 167000 & 0.273 & 0.81 & \\
\hline 358 & 100 & 900000 & 500000 & 100000 & 0.8 & 0.88 & \\
\hline 401 & 70 & 680000 & 500000 & 70000 & 0.86 & 0.88 & \\
\hline 15239 & 172 & 600000 & 600000 & 172000 & 0.71 & 0.71 & \\
\hline 1338 & 29 & 290000 & 350000 & 29000 & 0.91 & 0.9 & \\
\hline 10 & 1295 & 2000000 & 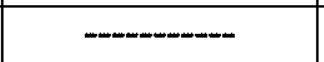 & 194000 & 0.03 & - & \multirow{6}{*}{$\begin{array}{l}\text { Figura 10, pag. 2012. PHILLIPS, F. M. ; } \\
\text { BENTLEY, H, W ; DAVIS, S. N. ; } \\
\text { ELMORE, D. ; SWANICK, G. B. (1985) }\end{array}$} \\
\hline 17 & 1090 & 2000000 & 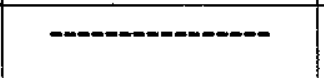 & 163000 & 0.18 & - & \\
\hline 26 & 60 & 500000 & --------------- & 90000 & 0.82 & ---------- & \\
\hline 25 & 105 & 500000 & "-------------- & 157000 & 0.685 & --------- & \\
\hline 32 & 114 & 1000000 & | & 171000 & 0.82 & 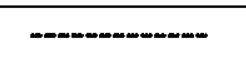 & \\
\hline 33 & 227 & 1000000 & 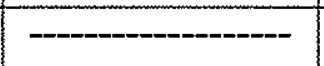 & 340000 & 0.65 & 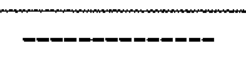 & \\
\hline
\end{tabular}



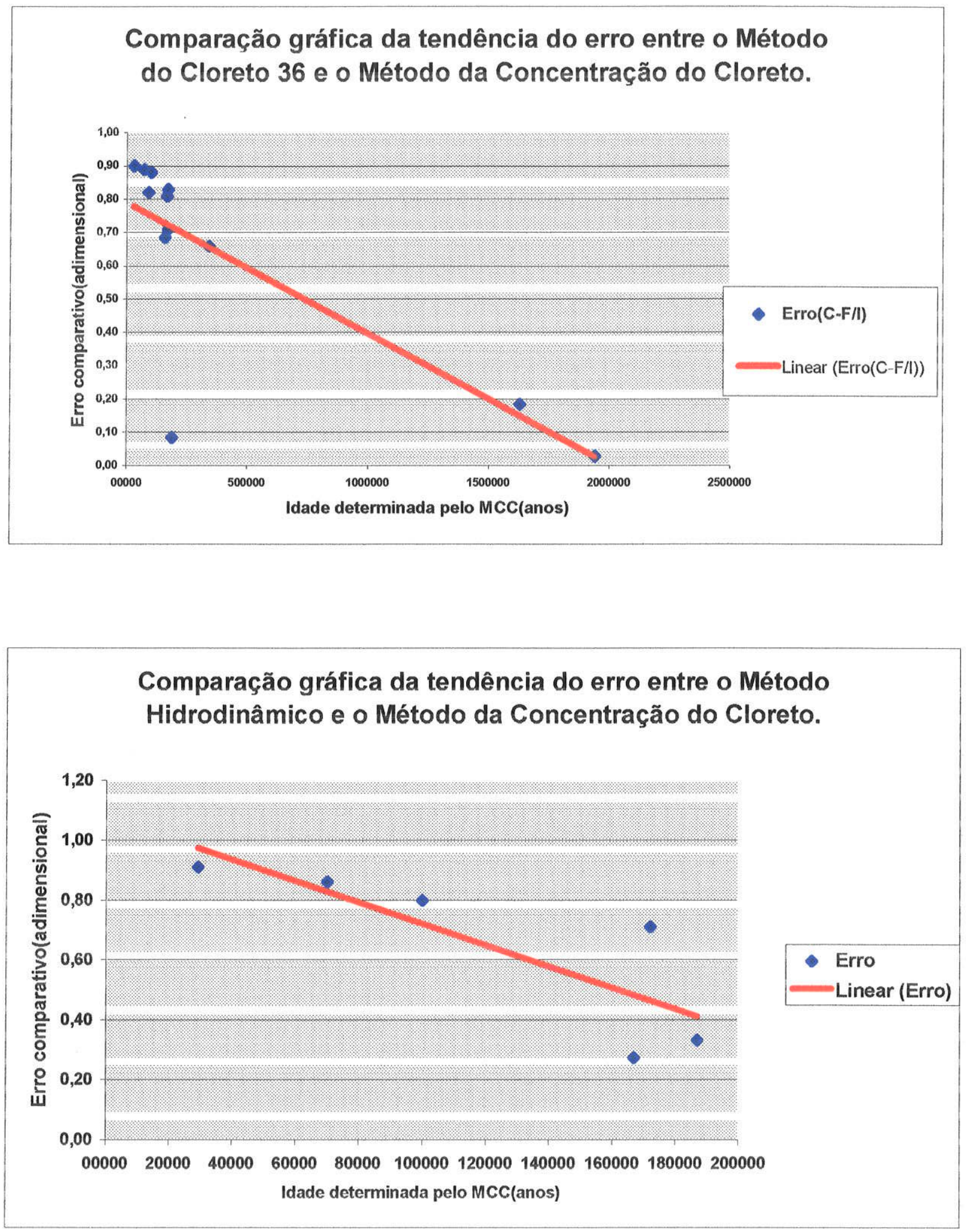

Figura 59. Gráficos comparativos das tendências dos erros entre os Métodos de ${ }^{36} \mathrm{Cl}$ e Hidrodinâmico com o Método da Concentração do Cloreto (MCC) onde se aprecia que os erros diminuem para as idades superiores aos milhões de anos. 


\section{Outras considerações necessárias ao Método da Concentração do Cloreto.}

\subsection{Comparação com o uso de outros componentes.}

O Método Hidrodinâmico e do ${ }^{36} \mathrm{Cl}$ não são os únicos que se tem utilizado para datar as águas subterrâneas. Alias dos isótopos radioativos, cujos melhores representantes são ${ }^{14} \mathrm{C},{ }^{18} \mathrm{O}$ e trítio, os trabalhos mais recentes têm explorado outros componentes naturais das águas (especificamente tratados de componentes inertes) com o fim de superar os defeitos tradicionais de alto custo e aplicação local (EDMUNDS, 2000; BARBECOT, 2000; BARTH, 2000; GHERARD, 2000; GRASBY, 2000), ainda que se mantém o uso do ${ }^{14} \mathrm{C}$ (BUCKAU, 2000 e CASTRO, 2000).

Neste sentido, o ion cloreto, entre os componentes inertes, tem chamado a atenção a outros especialistas. EDMUNDS et al, 2000, estabelece uma relação empírica de $\mathrm{He}$ (acumulado)/ $\mathrm{Cl}$ para inferir uma relação de idades. Considera o cloreto um indicador da procedência da zona de recarga, mas sublinha que ele não espera incremento nenhum do cloreto águas abaixo da zona de recarga. BARTH , 2000, utiliza as relações $\mathrm{B} / \mathrm{Cl} ; \mathrm{Na} / \mathrm{Cl}$ e $\mathrm{Br} / \mathrm{Cl}$, evidenciando que a relação $\mathrm{Br} / \mathrm{Cl}$ é linear mas em diferentes linhas segundo sejam salgadas ou doces. GHERARD et al, 2000 , admite que tanto $\mathrm{Na}$ como $\mathrm{Cl}$ crescem com o tempo em aproximadamente 15 e $16 \%$, mas não determina nada específico. GRASBY et al, 2000, analisa apenas os cátions, avaliando que os componentes enriquecidos em $\mathrm{Ca}$ e $\mathrm{Mg}$ das águas transformam-se em enriquecimentos de $\mathrm{Na}$ e $\mathrm{K}$.

Em sentido geral, para a procura de um método melhor e menos custoso que os tradicionais isotópicos, o cloreto está entre uns dos alvos mais atacado na década final do século $X X$. Pode apreciar-se que o demonstrado pelo autor no presente trabalho é o resultado conseguido entre estes intensos esforços atuais da comunidade científica, no empenho de encontrar uma via de datar as águas subterrâneas.

No entanto, com as novas referências, confeccionou-se a Tabela 10, na qual comparam-se os resultados das idades pelos outros métodos utilizados para datar águas. Pode apreciar-se boa coincidência entre os resultados dos métodos analisados com o proposto. Todos têm algumas diferenças entre si. BUCKAU et al, 2000, concluía para estes métodos referenciados, que davam muitas diferenças $e$, às vezes, resultados inconsistentes. O Método de Concentração do Cloreto (MCC) tem a particularidade de provir de um processo estabelecido, a Cloretogênese, que fundamenta a razão do enriquecimento com o tempo $e$, por isso, oferece uma conseqüência à interpretação que, com independência dos valores em anos, permite ordenar quais têm mais tempo de circulação subterrânea. 
Tabela 10. Comparação das idades das águas através de métodos atuais com 0 Método da Concentração de Cloreto.

\begin{tabular}{|c|c|c|c|c|c|c|c|c|c|}
\hline \multirow[t]{2}{*}{$\begin{array}{l}\text { No. Ponto na } \\
\text { referência }\end{array}$} & \multirow[t]{2}{*}{$\begin{array}{c}{[\mathrm{Cl}]} \\
(\mathrm{mg} / \mathrm{L})\end{array}$} & \multicolumn{4}{|c|}{$\begin{array}{l}\text { Método de Datação de águas utilizado } \\
\text { (anos) }\end{array}$} & \multicolumn{3}{|c|}{$\begin{array}{c}\text { Avaliação do erro com respeito } \\
\text { ao Método da Concentração do } \\
\text { Cloreto }\end{array}$} & \multirow[b]{2}{*}{ Fonte } \\
\hline & & Li & Mo & Hidrodinâmico & $\begin{array}{c}\text { Concentração } \\
\text { do Cloreto }\end{array}$ & $\mathrm{Li}$ & Mo & Hidrodinâmico & \\
\hline Grove 4 & 6.5 & 12800 & 9070 & 11800 & 9750 & 0.23 & -0.07 & 0.17 & \multirow{5}{*}{$\begin{array}{c}\text { Tabela 1, pag. } \\
741 \\
\text { Tabela 3, pag. } \\
748, \\
\text { Edmunds et al, } \\
2000\end{array}$} \\
\hline Grove 1 & 6.6 & 13700 & 8130 & 11900 & 9900 & 0.27 & -0.21 & 0.16 & \\
\hline Grove2 & 6.3 & 12500 & 8720 & 11700 & 9400 & 0.24 & -0.07 & 0.19 & \\
\hline Gainsbourogh & 24.9 & 37700 & 22200 & 40700 & 37350 & $\sim 0$ & -0.6 & 0.08 & \\
\hline $\begin{array}{l}\text { Corringham } \\
\text { Road }\end{array}$ & 54.5 & 50400 & 23900 & 118000 & 81750 & -0.6 & -2.4 & 0.30 & \\
\hline
\end{tabular}




\subsection{O processo da Cloretogênese e o Método da Concentração do Cloreto.}

No capítulo anterior exprimiu-se as características identificativas gerais deste processo que permitiu derivar um método para datar águas subterrâneas. A nomeação de cloretogênese ao processo de enriquecimento das águas em cloretos, pode ser associada a um processo que "cria" cloretos, mas não é esse o sentido pretendido pelo autor. Também não ajuda muito se apoiar na dissolução de evaporitos com o fim de justificar a crescente e regularizada concentração de cloretos nas águas subterrâneas. O sentido certo desta nomeação pretende abranger a existência de um processo regularizado e natural que "gera" aumento da concentração de cloretos em dissolução nas águas, com independência das causas implicadas no processo estabelecido. $\mathrm{O}$ fato certo é que existe e, como já se explicou, outros reconhecidos especialistas que admitem a dificuldade da justificação do incremento do cloreto nas águas, que, nem sequer está totalmente justificado nas águas de mar (ANDREWS et al, 1996).

Para poder associar e interpretar o MCC com o processo da Cloretogênese, precisa-se esclarecer as possiveis causas que devem condicionar-lo. Para isso, é necessário valorar os resultados extremos do método para as condições limites conhecidas de concentração do cloreto : precipitações e mar.

No caso cubano, a concentração do cloreto nas águas de chuvas é de 2,73 $\mathrm{mg} / \mathrm{L}$ e Israel, de $11,0 \mathrm{mg} / \mathrm{L}$. Aplicando a equação (1), os resultados são de 4000 e 16500 anos, respectivamente. O valor geral do cloreto nas águas de mar é de $19000 \mathrm{mg} / \mathrm{L}$, que da um valor de 28,5 Ma (milhões de anos).

Em primeiro lugar parece contraditório uma água de chuva tão "velha" para os padrões gerais utilizados que consideram-na de tão recente como uma semana (BENTLEY et al, 1985). Drever, 1988, evidencia com a composição isotópica das precipitações que "a água é meteórica, mas foi formado em tempo geológico passado", o que permite considerar de não tão anômalo as idades determinadas para Cuba e Israel. $\mathrm{Na}$ escala geológica, dezenas de milhares de anos praticamente abrangem o Holoceno - Plistoceno Superior. No caso do mar, a idade calculada está por baixo do componente diluído nas suas águas com o maior tempo de residência, o cloreto (73 Ma, HOLLAND, 1985; $131 \mathrm{Ma}$, ANDREWS, 1996).

Mas, como não se pode depreciar a dinâmica da Natureza, dentro da qual, o processo da Cloretogênese é mais um dos que depende dos resultados da ação de todos os processos que nela operam, o sentido físico que a idade calculada por este método significa é que a concentração de mar alcançada tem essa idade como mar na totalidade da sua concentração e não como o tempo de vida dos cloretos diluídos nas suas águas. Os processos de intercambio atmosféricos, com outras águas e com as correntes oceânicas, assim como as influencias locais e regionais dos movimentos tectônicos e erosivos, geologicamente constante, mantém em equilíbrio os valores de concentração do cloreto, representativos da idade do processo nessa etapa e nessa região e, por isso, representativos da idade dessas águas nessa região. 
Mas, a regularidade evidente desse processo, porquanto é derivada do processamento das águas de todas as partes do Mundo, as idades calculadas devem ser comparativas entre regiões diferentes.

Neste sentido, uns dos problemas hidrogeológicos mais estendidos, a intrusão marinha, causada pelo encontro das águas continentais drenadas, que por principio neste exemplo, mais jovens, com as águas marinhas entrantes, mais velhas, nas zonas costeiras, pode ser interpretada como a concentração predominante das águas misturadas, segundo o ponto de amostragem, que avaliará a idade resultante. Pode se interpretar também, que no encontro de águas de diferentes concentrações, a mistura resultante avaliará a sua idade.

O exemplo anterior não é a evolução do processo, senão a interpretação do calculo das idades para o caso típico de misturas de águas de etapas diferentes do mesmo processo. Tal mistura pode acontecer dentro de uma mesma região quando se encontram águas de diferentes concentrações de cloreto por variadas causas hidrogeológicas. No caso das concentrações existentes nas áreas emergidas, longes do mar, o processo é comum a todas as águas, logo de infiltradas. Nas áreas continentais o processo poderá exprimir-se melhor quanto mais longe do mar. A complexidade da interpretação da avaliação dos pontos aumentará na medida que o mar fica mais perto. Nas zonas insulares será de máxima complexidade.

A regularidade do processo de Cloretogênese e a determinação da idade particular das águas estão sujeitas à avaliação particular das condições hidrogeológicas e a escala de trabalho da região sob estudo, porquanto áreas de grande concentração de minérios, rochas evaporitos, solos salinizados e residuais da atividade humana, podem confundir a adequada interpretação, devido a que os possíveis cloretos presentes, não são procedentes de um enriquecimento natural gradual.

\section{Aplicação do Método da Concentração do Cloreto à Interpretação hidrogeológica da região de estudo.}

O reconhecimento regional e a interpretação hidrogeológica da região de estudo e a sua inter-relação com as águas minerais existentes é alvo desta pesquisa. No sentido clássico da interpretação hidrogeológica, os resultados apresentados enquanto às tipologias hidrogeoquímicas determinadas e aos comportamentos gerais das correlações dos ions dissolvidos nas águas subterrâneas podem ser suficientes para a avaliação da região.

O intuito de precisar até onde e como a tendência geral do comportamento dos ânions das águas provenientes das diferentes litologias permitia encontrar uma identificação comum a todas as águas subterrâneas deu como resultado o descobrimento do processo de Cloretogênese e o Método da Concentração do Cloreto para datar as águas. 
Neste sentido, com estas novas ferramentas, evidencia-se a necessidade de demonstrar a utilidade que as mesmas tem para a interpretação hidrogeológica regional, o que implica também, ter que argumentar a seqüência dos passos interpretativos.

Foi evidenciado que cada um tipo hidrogeoquímico de água, pelas características de escala territorial, parte de uma ilha, e as condições da amostragem superficial dos pontos avaliados, é um conjunto de variados tipos hidrogeoquímicos, dentro do qual, o valor representativo é o predominante (Vide Figura 40 ).

Utilizando 0 íon cloreto como o indicador característico das águas subterrâneas, que é o mesmo que permitirá determinar a idade dos conjuntos a avaliar, analisou-se, em primeiro lugar, a correspondência da posição do cloreto nos gráficos obtidos para, a seguir, precisar o valor característico representativo da água dessa litologia.

A Figura 60 compara a correspondência das posições relativas das concentrações de cloreto nos gráficos utilizados pelo autor, Piper e de Correlações (Scatter diagrame), com os valores obtidos no histograma das águas provenientes dos granodioritos de Camaguey. Do histograma pode se apreciar a existência de uma faixa de valores da concentração do cloreto que estão indicando a variabilidade das proporções presentes.

É evidente que este valor representativo da concentração predominante do cloreto não altera as proporções dos restantes íons na tipologia hidrogeoquímica específica, pelo que o seu uso avaliará o enriquecimento particular deste ânion nas águas dentro do conjunto litológico sob análise. Em conseqüência com o processo da Cloretogênese, pode se considerar, para os fins do cálculo das respectivas idades, que os valores representativos especificos das águas devem ser aqueles mais abundantes para a dissolução e, aqueles menos abundantes, mas de maior concentração, serão provenientes das águas em etapa mais avançada do processo ou de misturas neste sistema particular da circulação das águas subterrâneas dentro dos granodioritos de Camaguey.

Sob este princípio discriminatório, o valor mais freqüente da concentração do cloreto $(\sim 40-50 \%)$ determinará a caracterização representativa da etapa principal do processo da Cloretogênese e o menos freqüente $(\sim 10-20 \%)$, a caracterização das águas do sistema na etapa mais avançada do processo.

A Figura 61 apresenta as avaliações dos histogramas do cloreto das águas subterrâneas das formações geológicas analisadas nesta pesquisa. Pode se apreciar, em primeiro lugar, que o fato de utilizar o cloreto como indicador não dificulta nem se confunde com as demais águas de outras rochas, ainda que os valores mais freqüentes sejam similares (Comparar as serpentinitas, granitos Camaguey, formações Guines e Vila Roja). Levanta curiosidade a Formação Vertientes, a única à qual podem deduzir-se dois máximos de freqüência majoritária. O autor preferiu manter os dois valores para posterior análise, devido a que esta formação é de reconhecida impermeabilidade e, por isso, as 


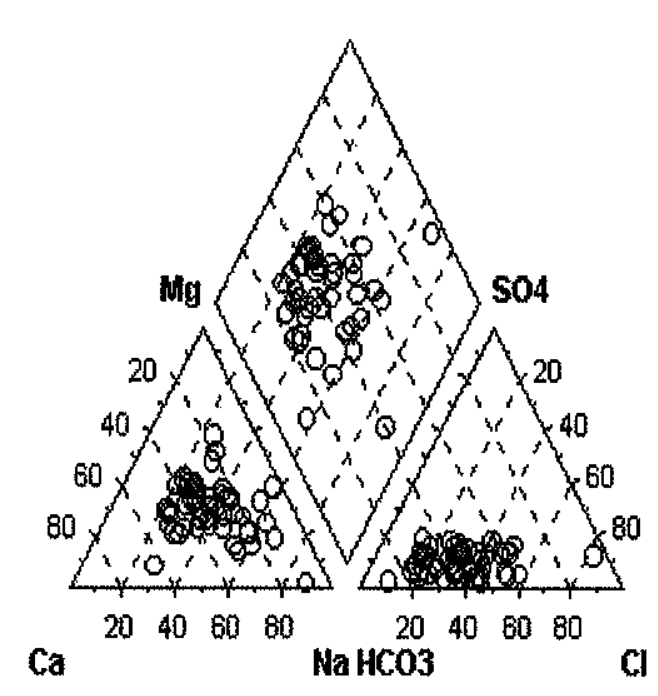

Frequency (counts)

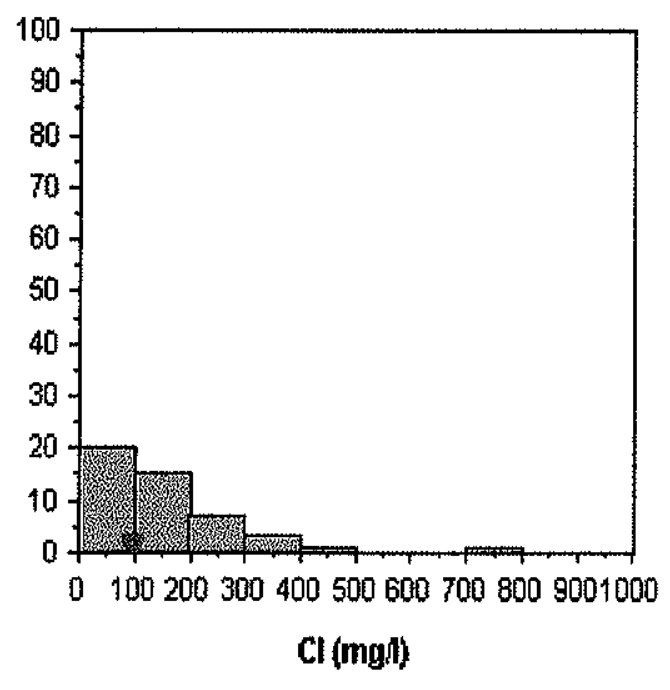

TDS

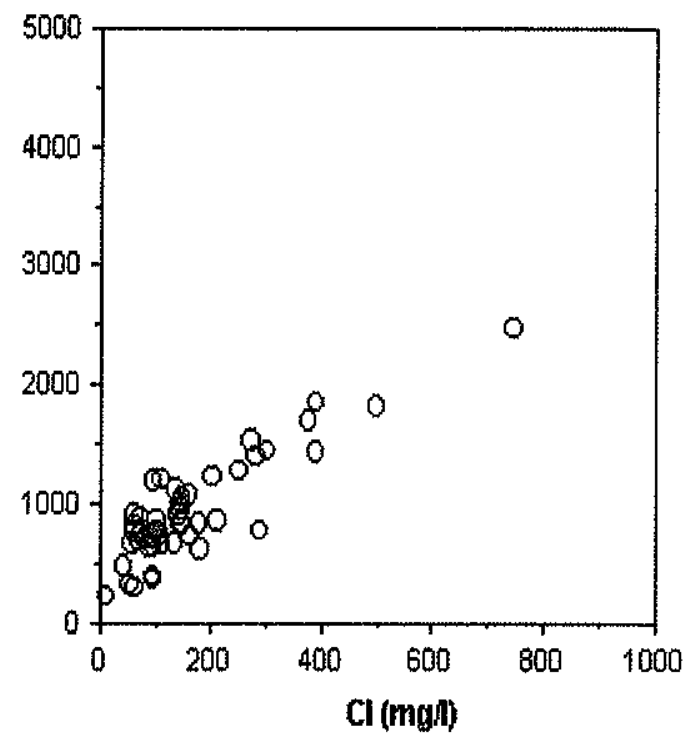

Granodioritos Camaguey

Figura 60. Verifica-se que o valor de maior freqüência do cloreto no histograma das águas subterrâneas provenientes dos granodioritos de Camaguey, está em correspondência com o valor do cloreto representativo do tipo hidrogeoquímico $(\mathrm{HCO} 3-\mathrm{Ca}-$ $\mathrm{Mg}$ ) no gráfico Piper e no gráfico de correlação TDS/CI 


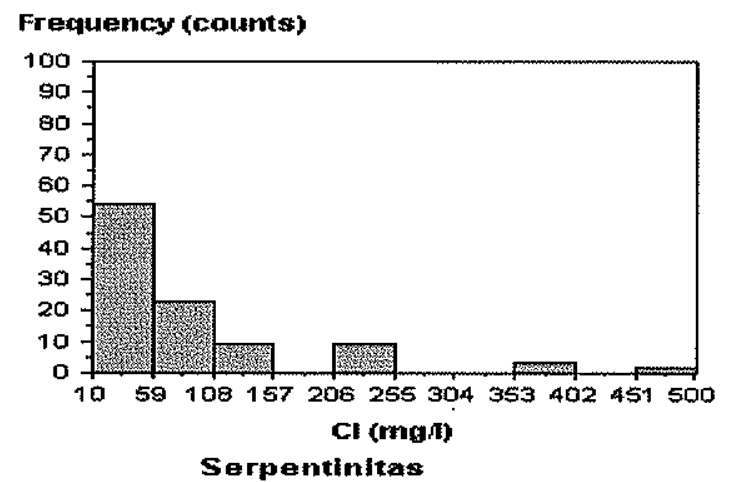

Valor mals frequente do cloreto: $100 \mathrm{mg} / \mathrm{l}$. Valor menos frequente do cloreto: $150 \mathrm{mg} / \mathrm{L}$

Frequency (counts)

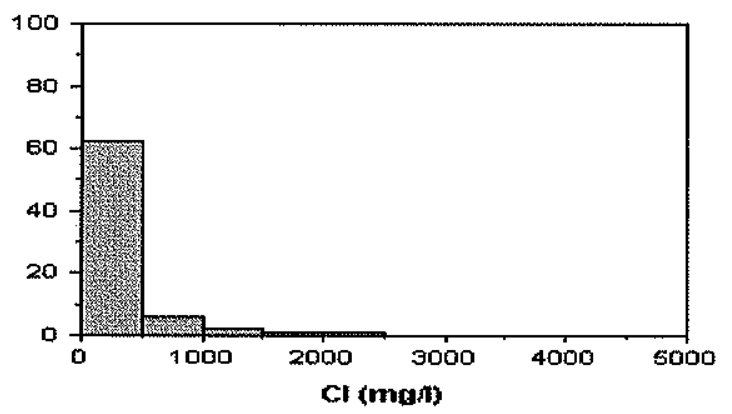

Gramodiorito Lass Tumas

Valor mais frequente do cloreto:

Valor menos frequente do cloreto: 1000 mgll

Frequency (counts)

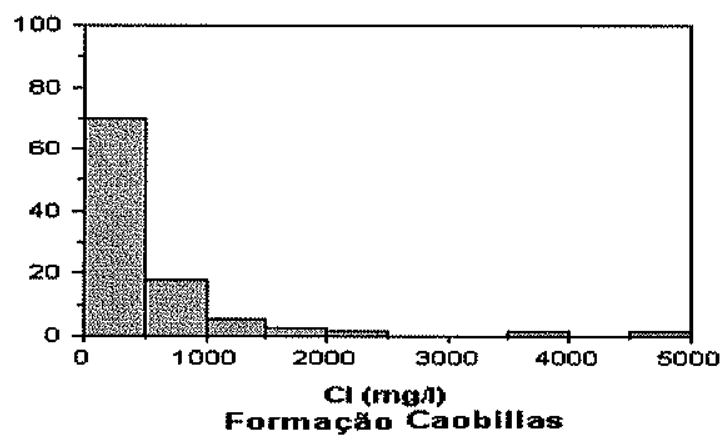

Valor mais frequante do cloreto: $\quad 500 \mathrm{mg} / \mathrm{L}$

Valor menos frequente do cloreto: $4000 \mathrm{mg} / \mathrm{h}$

Fraquency (coumts)

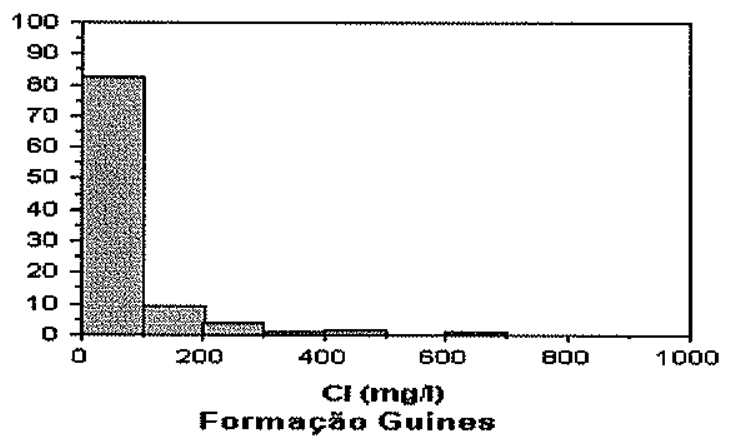

Valor mals frecuente da cloreto:

$100 \mathrm{mg} / \mathrm{L}$

Valor menos frequente do cloreto: $200 \mathrm{mg} / \mathrm{L}$
Frequency (counts)

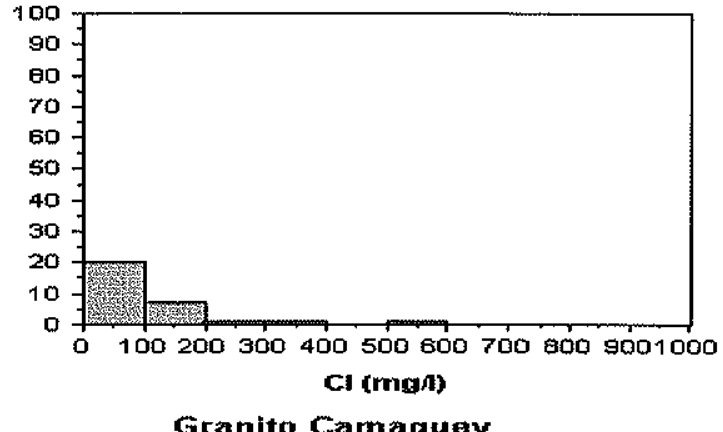

Valor mals frequemte do cloreto: $100 \mathrm{mg} / \mathrm{L}$ Valor menos frequente do cloreto: $600 \mathrm{mg} / \mathrm{L}$

Freauency (counts)

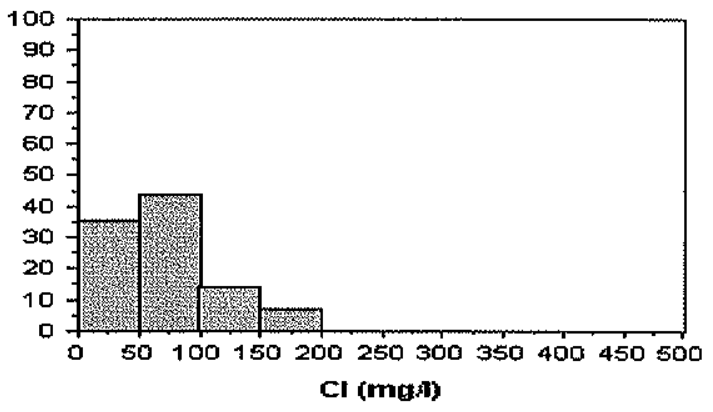

Formaçăo Contramaestre

Valor mais frequente do cloreto: $100 \mathrm{mg} / \mathrm{L}$

Valor menos frequente do cloreto; $200 \mathrm{mg} / \mathrm{L}$

Frequency (courts)

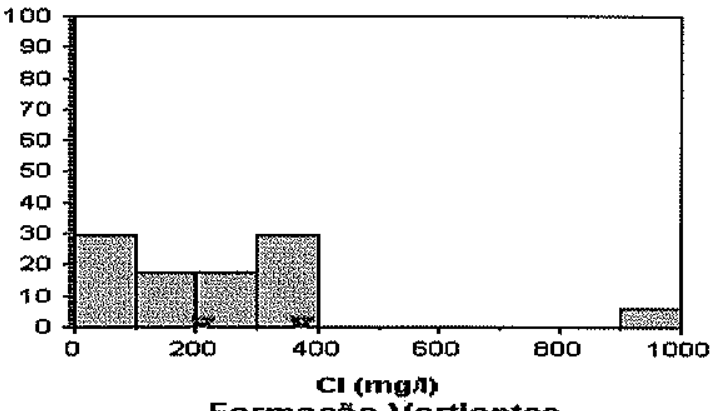

Formaço Vertientes

Valor mais frequante do cloreto: $200 \mathrm{mg} / \mathrm{L}$

Valor memos frequente do cloreto: $1000 \mathrm{mg} / \mathrm{L}$ Frequency (counts)

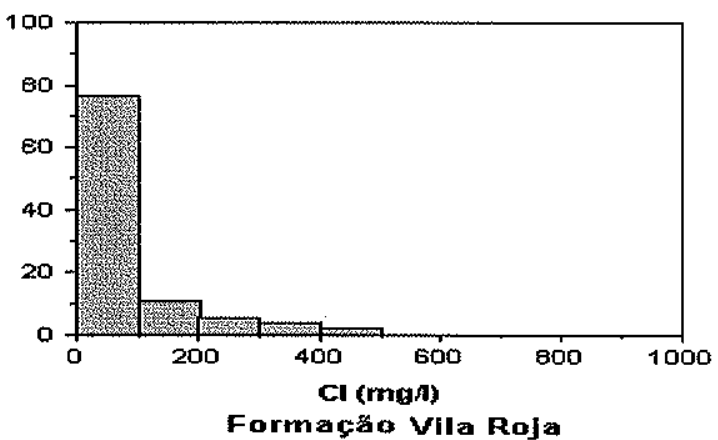

Valor mals frequente do cloreto: $100 \mathrm{mg} / \mathrm{L}$ Valor menos frequente do cloreto: $200 \mathrm{mg} / \mathrm{L}$

Figura 61. Histogramas do conteúdo de cloreto das águas subterrâneas provenientes dos principais conjuntos litológicos analisados na região de estudo. 
concentrações de cloreto das suas águas podem estar relacionadas com uma lenta circulação que, comparativamente, permita exprimir o processo da Cloretogênese algo separado dos restantes conjuntos de águas no sistema regional.

A Tabela 11 apresenta os resultados do cálculo das respectivas idades pelo método MCC, a partir das concentrações dos cloretos nas águas das diferentes formações geológicas analisadas nesta pesquisa.

Os resultados conseguidos representam o confronto principal com a prática, pois se existir erros na concepção do processo e nas considerações para aplicar o método, podem se originar resultados contraditórios com a realidade geológica da região estudada. A primeira condicionante geológica, e lógica hidrogeológica, é que as águas subterrâneas circulando não devem ser mais velhas do que a idade da formação do conjunto litológico. É evidente, sob análise hidrogeológica, que as águas começaram circular logo que o sistema rochoso existiu. As demais condicionantes são aquelas que permitam acreditar os resultados numéricos sob a concepção do comportamento lógico da Natureza, as quais, no presente caso, são de não discordar nem se opor com as leis físico-químicas da circulação das águas subterrâneas.

Para melhor discussão dos resultados da Tabela 11 preparou-se a Figura 62, onde podem ser observadas as posições estratigráficas, segundo as idades calculadas, das águas analisadas.

A partir daqui, o autor fará referências a águas jovens e velhas, mesmo assim, às suas gradações, porquanto nesta pesquisa essas classificações têm já o seu devido fundamento de cálculo.

As águas mais jovens da região de estudo e com faixa de idades similares são as provenientes e circulando pelas serpentinitas e formações Contramaestre, Guines e Vila Roja. As serpentinitas, ou Complexo Ofiolítico, apesar de estruturar o conjunto primário, surgido a finais do Jurássico dentro a Plataforma das Bahamas, está situado nas alturas máximas da região, o que lhe permite uma função receptora superior das precipitações existentes, que lhe condiciona uma baixa salinidade, representativa da sua recente constituição.

Enquanto as águas da Formação Guines, devido que ocuparem uma ampla extensão nas altitudes mais baixas do território entre as formações cretáceas do Arco Vulcânico e a zona costeira da região e devido a sua alta permeabilidade, permite-lhe recepcionar a precipitação acima dela e o escoamento proveniente das formações mais elevadas pré-neogénicas. Vila Roja é uma formação do Quaternário, costeira, de permeabilidade heterogênea, estratigráficamente acima da Formação Guines, que lhe outorga uma função similar à anterior, mas mais limitada.

As águas dos granitos e granodioritos de Camaguey têm uma parte da mesma idade que as anteriores descritas, mas a faixa de idades é maior. Pode conceber-se que têm uma função similar de recarga, por uma parte, e outras causais que condicionam águas mais velhas na sua circulação. 
Tabela 11. Idades das águas subterrâneas que circulam nos conjuntos litológicos da Região de Estudo Cuba Centro Oriental calculadas pelo o autor (Método da Concentração do Cloreto).

\begin{tabular}{|l|l|l|l|l|}
\hline \multirow{2}{*}{ Litologia } & \multicolumn{3}{|c|}{$\begin{array}{l}\text { Intervalo da apresentação } \\
\text { de maior frequencia do Cl } \\
(\sim>50 \%)\end{array}$} & $\begin{array}{l}\text { Intervalo da apresentação } \\
\text { de menor frequencia do CI } \\
(\sim>10 \%)\end{array}$ \\
\cline { 2 - 5 } & $\begin{array}{c}\text { Valor em } \\
\text { mg/L }\end{array}$ & $\begin{array}{c}\text { Idade } \\
\text { (anos) }\end{array}$ & $\begin{array}{c}\text { Valor em } \\
\text { mg/L }\end{array}$ & $\begin{array}{c}\text { Idade } \\
\text { (anos) }\end{array}$ \\
\hline Serpentinita & 100 & $<150$ 000 & 150 & $<250000$ \\
\hline $\begin{array}{l}\text { Granito } \\
\text { Camaguey }\end{array}$ & 100 & $<150000$ & 600 & 900000 \\
\hline $\begin{array}{l}\text { Granodiorito } \\
\text { Camaguey }\end{array}$ & 100 & $<150000$ & 400 & 600000 \\
\hline $\begin{array}{l}\text { Granodiorito Las } \\
\text { Tunas }\end{array}$ & 500 & 750000 & 1000 & 15000000 \\
\hline $\begin{array}{l}\text { Formação } \\
\text { Contramaestre }\end{array}$ & 100 & 150000 & 200 & 300000 \\
\hline $\begin{array}{l}\text { Formação } \\
\text { Caobillas }\end{array}$ & 500 & 750000 & 4000 & 6000000 \\
\hline $\begin{array}{l}\text { Formação } \\
\text { Vertientes }\end{array}$ & 200 & $\begin{array}{l}300000 \\
600000\end{array}$ & 1000 & 1500000 \\
\hline $\begin{array}{l}\text { Formação } \\
\text { Guines }\end{array}$ & 100 & 150000 & 200 & 300000 \\
\hline $\begin{array}{l}\text { Formação } \\
\text { Vila Roja }\end{array}$ & 100 & 150000 & 200 & 300000 \\
\hline
\end{tabular}




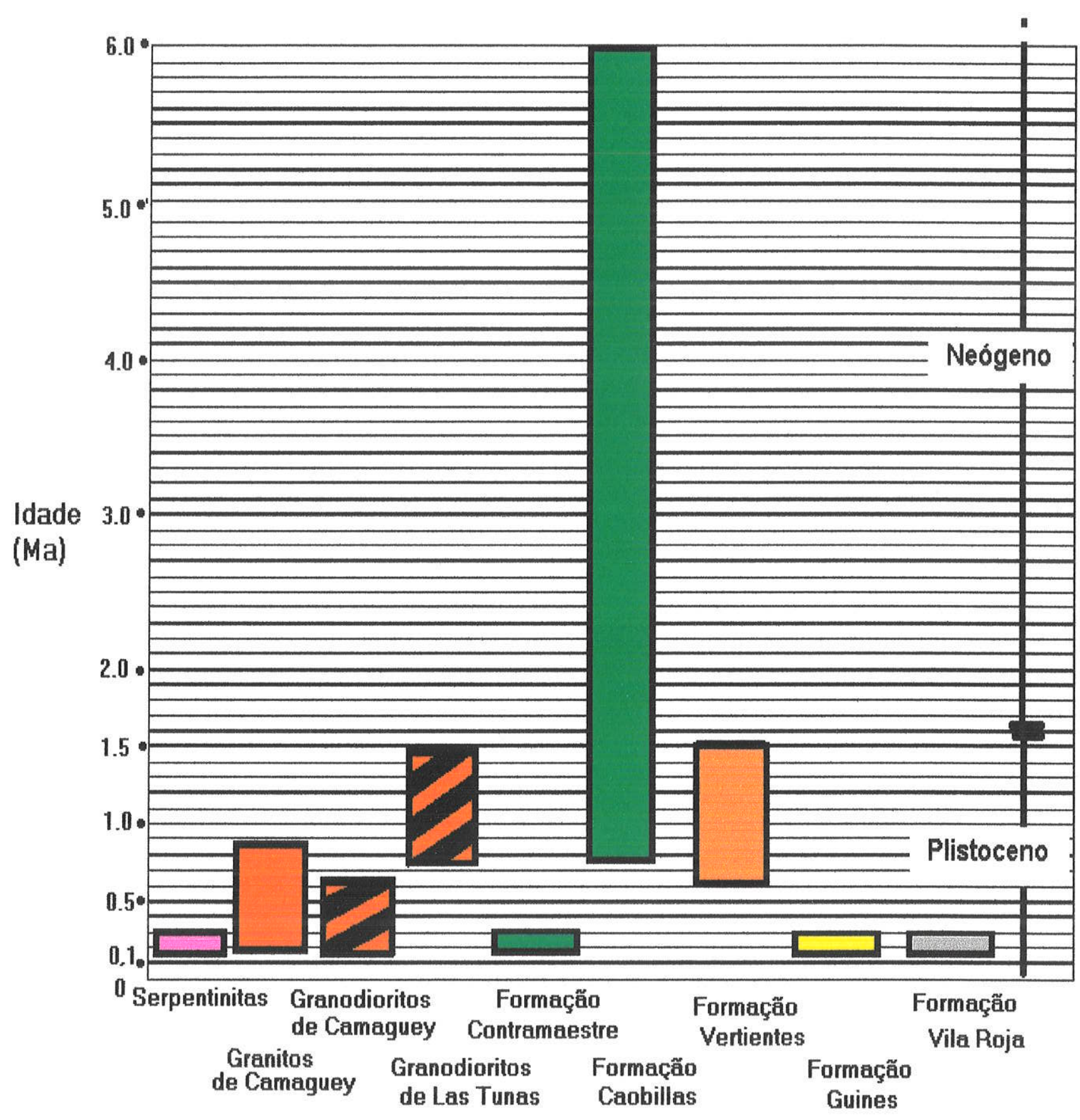

Figura 62. Representação gráfica da distribuição das idades das águas subterrâneas que circulam pelos diferentes conjuntos litológicos da região de estudo. Pode se apreciar que a faixa de idades predominantes corresponde com 0 recente Plistoceno, enquanto apenas as águas da Formação Caobillas alcançam os valores máximos da região.

(Nota : As cores mantêm a mesma correspondência com as idades geológicas das respectivas formações utilizadas no texto) 
Os casos relacionados com as idades mais velhas dos granodioritos Las Tunas, Formações Caobillas e Vertientes, parecem representar etapas mais avançadas da evolução do processo. O objetivo é poder fazer uma hipótese dos mecanismos do funcionamento geral do seu sistema hidrogeológico. Nesta região em particular, como primeira sob uma análise com o apoio das posições temporais das águas devido a um processo que opera apenas no sentido do enriquecimento do cloreto, qualquer uma hipótese tem que conjugar as leis naturais que obrigam o descenso das águas, pelo aumento do seu peso devido ao aumento da sua densidade e conseqüente aumento das resistências que apresenta o meio geológico na sua descida. Também não pode ser desconsiderado que as águas menos densas flutuam acima das mais densas, portanto, águas de menor salinidade, mais jovens, fisicamente têm que estar acima das mais salinizadas, mais velhas, qualquer um que seja o valor relativo das idades que as relacionem. Sob esse esquema conceitual de posições que devem apresentar as águas segundo as suas concentrações, analisou-se a distribuição do cloreto nas formações dos serpentinitos (Complexo Ofiolítico), Caobillas (Arco Vulcânico) e Guines (Cobertura Cenozóica).

A Figura 63 apresenta a referida seleção dentro do contexto geológico da região Ciego de Ávila - Camaguey. Assim destacadas, pode se apreciar a irregularidade dos contornos e contatos Ofiolitos - Caobillas. A Formação Guines de Ciego de Ávila, mais ao oeste, como parte da Cobertura Cenozóica, contorna estratigraficamente, ao norte e sul, as mencionadas anteriormente, não representadas com abundância suficiente na área de Camaguey. $O$ interesse da seleção considerada é analisar a distribuição das concentrações do cloreto para os casos extremos na região de estudo de : 1) a representação emergida mais velha, os ofiolitos; 2) a representação litológica do Cretáceo, mas com as águas de maior idade, Form. Caobillas e; 3 ) a representação recente, pertencente ao período de calma geológica e que, aliás, constitui a litologia mais aqüifera de Cuba. As formações restantes, estão situadas pelas idades determinadas das suas águas e estratigráficamente entre as selecionadas, o que permitirá interpolar as interpretações resultantes da análise efetuada.

Do ponto de vista do processamento, logo após análise da função dos componentes aniônicos dentro as águas subterrâneas procedentes das distintas formações geológicas como um valor escalar, procedesse à sua análise como valor vetorial, a sua distribuição na área de estudo.

\subsection{Interpretação da análise às manifestações na superfície}

Como foi esclarecido no Capítulo $V$, todas as amostras para análise química das águas, foram obtidas na superfície do nível de água dos correspondentes pontos. Não estão reportadas amostragens a profundidades inferiores ao seu nivel existente, no momento da coleta. Esta especificação fundamenta a afirmação que as diferentes concentrações, menores ou maiores, são 


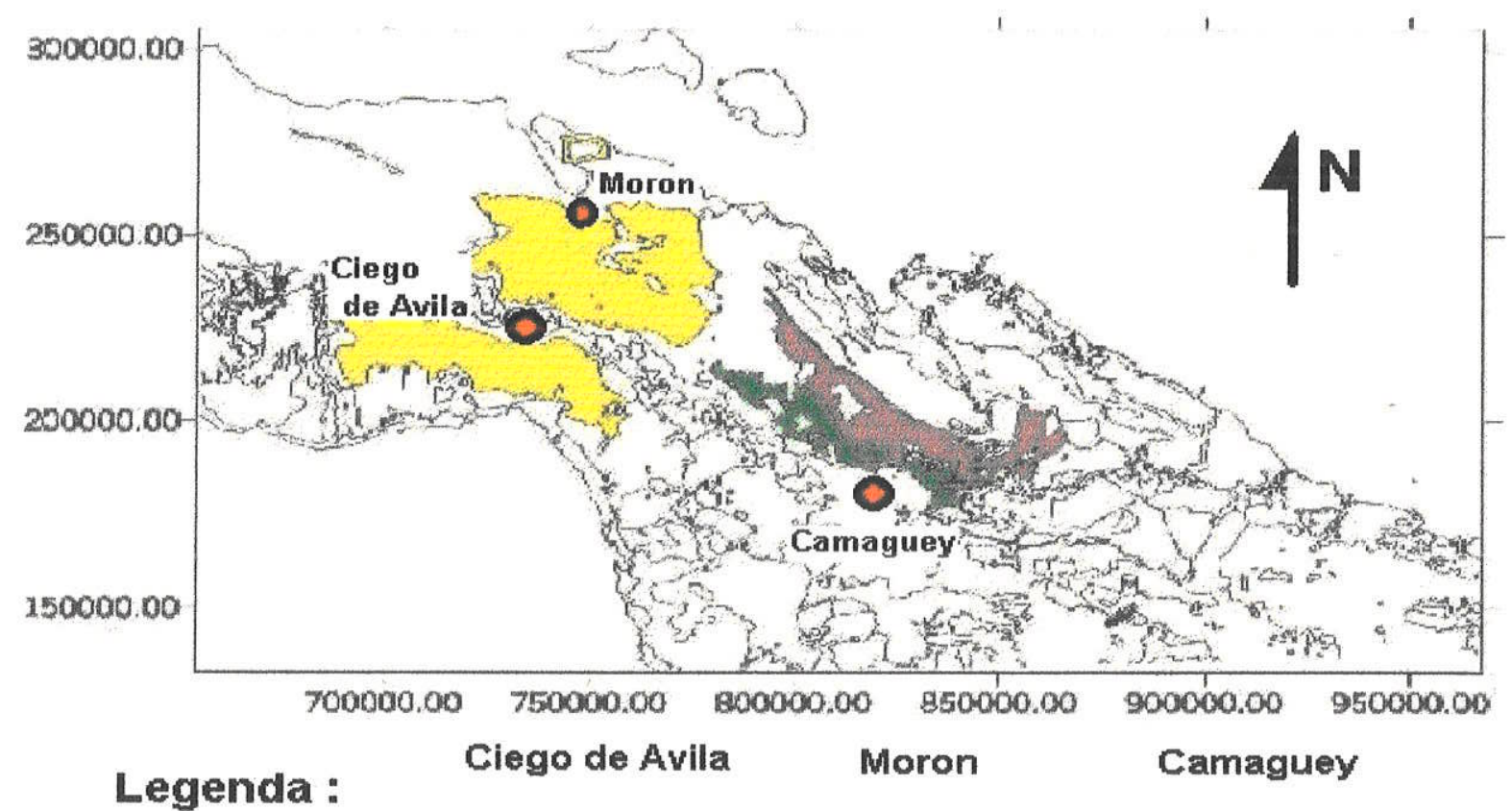

Legenda:

Complexo Ofiolitico

Formaçăo Caobillas

Formaçăo Guines

Q Capitais das respectivas provincias

Outra cidadede referęncia Escala : $1: 1750000$

Figura 63. Distribuição territorial das formações geológicas selecionadas na área de estudo.

TDS (mgii)

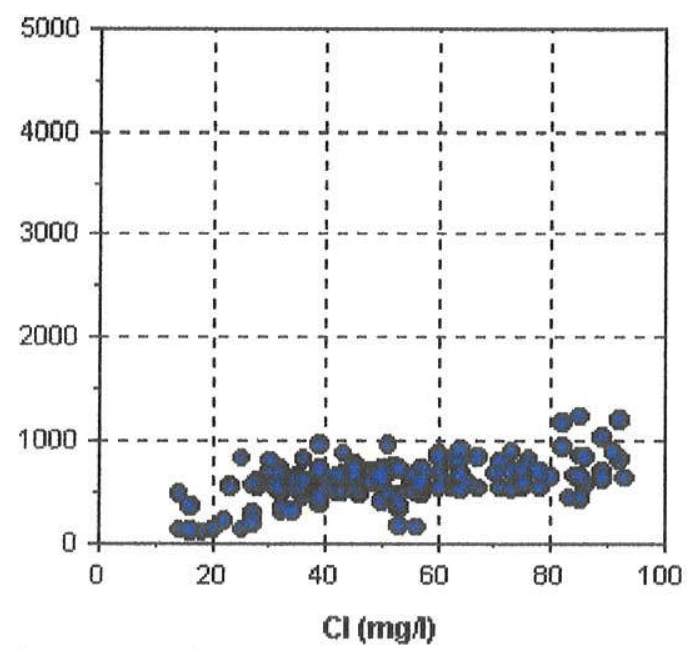

Legenda :
TDS (mgn)

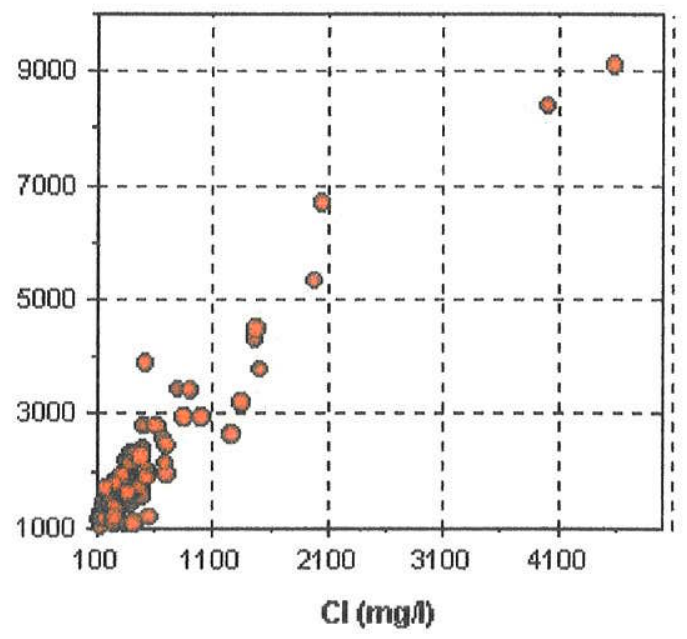

O $\begin{aligned} \mathrm{Cl} & >100 \mathrm{mg} / \mathrm{L} \\ \mathrm{STD} & >1000 \mathrm{mg} / \mathrm{L}\end{aligned}$

Figura 64. Argumentação dos limites de cloretos utilizados na análise da sua distribuição espacial nas águas subterrâneas que circulam pelas formações qeolóqicas selecionadas. 
manifestações das águas subterrâneas na superfície do território. Para conciliar estas condicionantes numa hipótese racional, pode, então, conceber-se que a manifestação em superfície de águas mais velhas que as circundantes jovens, deve obedecer ao seu retorno das profundidades até as quais chegou para obter essa concentração como parte da etapa que desenvolvia.

Isso não quer dizer que as águas todas, quando alcançam maior salinidade, estão retornando à superfície, senão que uma parte do volume descido pela gravidade retorna à superfície. Do ponto de vista físico, as partes finais da coluna do volume de água têm maior pressão, devido ao próprio peso das partes superiores dessa coluna, unido às reduções das permeabilidades do meio rochoso, inerentes à diminuição dos espaços livres pelo aumento da profundidade. No encontro com planos de fraturas ou contatos litológicos, de relativa maior permeabilidade em sentido geral, que interceptam o percurso da descida destas águas, permite condicionar um caminho de retorno de uma parte do volume delas a superfície. As restantes águas continuam na evolução do processo de enriquecimento de cloreto até a concentração que lhe permitam as condicionantes especificas existentes.

A explicação anterior pode se conceber quando se analisa a distribuição espacial destes componentes nas formações geológicas estudadas. Com o fim de manter similares elementos interpretativos utilizou-se a distribuição dos cloretos nas águas das formações selecionadas, em lugar dos STD e condutividades delas. A Figura 64 visualiza a equivalência dos valores de cloretos menores e maiores aos $100 \mathrm{mg} / \mathrm{L}$ com os STD menores e maiores aos $1000 \mathrm{mg} / \mathrm{L}$, respectivamente.

Deve se sublinhar, como mais uma vantagem da aplicação deste processo da cloretogênese, que permite a análise regional da circulação das águas subterrâneas com a interpretação da distribuição dos isovalores dos cloretos no território, qualquer uma que sejam as procedências e tipos das águas existentes.

Até hoje, a aplicação da análise da distribuição dos valores de cloretos mais conhecida é aquela relacionada com a intrusão marinha nos aqüiferos costeiros. No caso a seguir será aplicada para uma análise hidrogeológico regional geral.

A Figura 65 apresenta os contornos dos valores da concentração dos cloretos das águas subterrâneas para as faixas extremas menores de $100 \mathrm{mg} / \mathrm{L}$ (linhas em azul) e maiores de $100 \mathrm{mg} / \mathrm{L}$ (linhas em vermelho). Para o sentido da interpretação a efetuar, deve-se ter presente que, enquanto os valores inferiores aos $100 \mathrm{mg} / \mathrm{L}$ de cloreto são similares para todas as formações, o valor máximo dos valores superiores aos $100 \mathrm{mg} / \mathrm{L}$, são diferentes para cada formação

Pode ser visto na figura que a distribuição maioritária das águas de menor mineralização (< $100 \mathrm{mg} / \mathrm{L}$ de $\mathrm{Cl}$ e $<1000 \mathrm{mg} / \mathrm{L}$ de STD) ocupam as partes centrais do corpo ofiolítico, enquanto as concentrações maiores, manifestam-se 


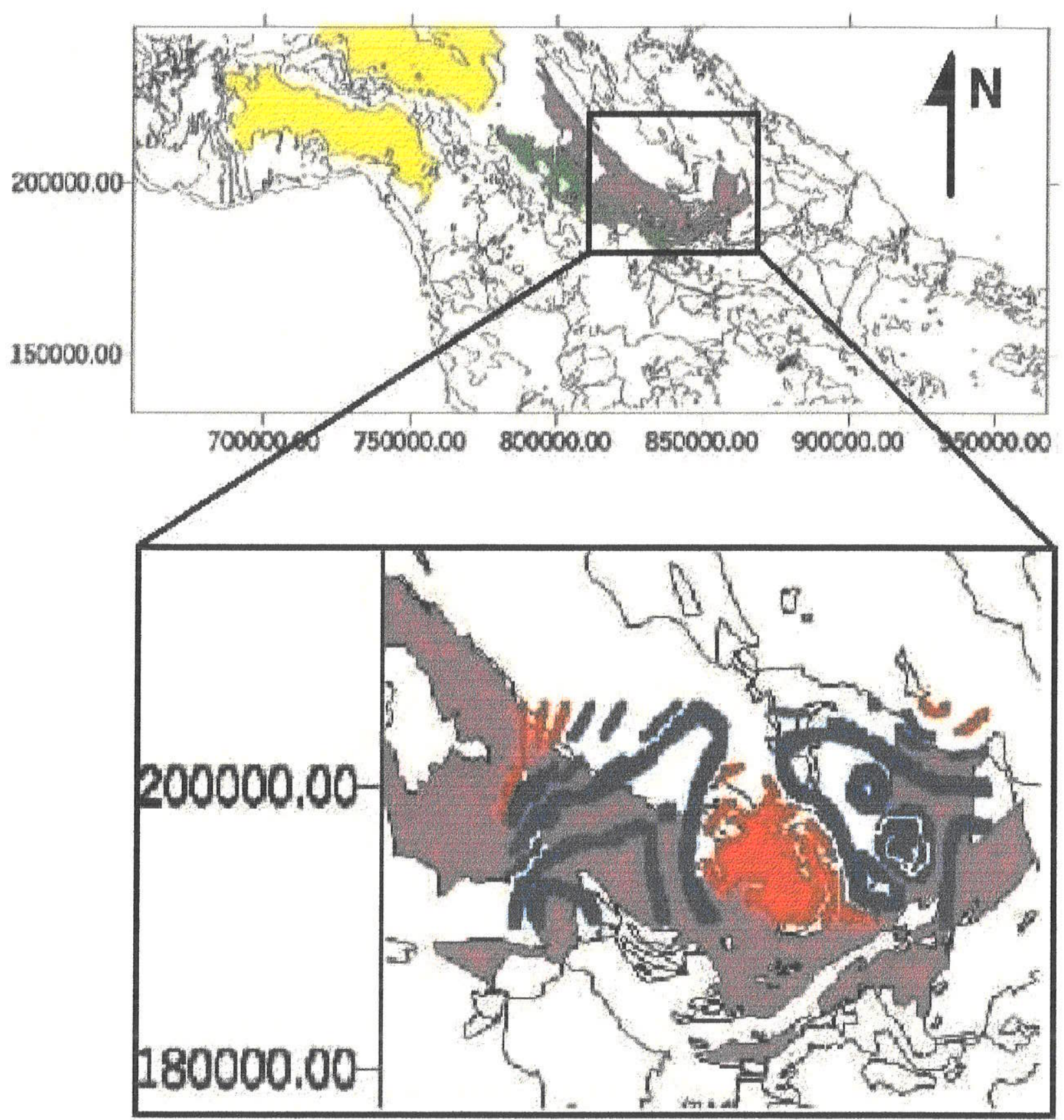

\section{Legenda:}

$\square$ Complexo ofiolitico $\square$ Formaçăo Caobillas $\square$ Formaçăo Guines

Linhas em azul : $\mathrm{CI}(0-100 \mathrm{mg} / \mathrm{L})$ Linhas em vermelho : $\mathrm{Cl}(120-360 \mathrm{mg} / \mathrm{L})$

Escala : 1:1750000

Figura 65. Distribuição dos cloretos nas águas subterrâneas que circulam pelo Complexo Ofiolítico na região de estudo. 
nos contatos. Conseqüentemente com a baixa salinidade das águas nos centrais do corpo ofiolítico, enquanto as concentrações maiores, manifestam-se nos contatos. Conseqüentemente com a baixa salinidade das águas nos ofiolitos, evidenciada nos capítulos anteriores, e segundo os valores da sua máxima concentração do cloreto, suas águas ainda não alcançam a classificação de salinizadas, como as restantes a comparar (360 mg/L).

Neste sentido, o representado é a tendência das suas águas incrementar as suas concentrações em cloretos na medida que correm do maciço em direção da periferia do corpo. No caso particular do centro criado na flexão da distribuição dos ofiolitos, pode ser devido à circulação em direção aos contatos, dentro das segregações litológicas dos ofiolitos em peridotitos (tectonitos) e sua forma cumulativa/transicional, bem desenvolvidas especificamente nessa parte do maciço, segundo Itrurralde-Vinent, 1994.

A divisão estabelecida de concentrações das águas subterrâneas abaixo e acima dos $100 \mathrm{mg} / \mathrm{L}$ de cloretos permite utilizar o critério comum para todas as formações geológicas de águas de infiltração recente e águas com tendência ao aumento da concentração ou envelhecendo, respectivamente. Tal critério, no caso dos ofiolitos, permite estabelecer o seu envelhecimento em direção aos contatos do maciço. Os contornos resultantes entre o fim e principio da divisão estabelecida apresentam destacadas tendências nas direções NE-SO e NO-SE.

A Figura 66 apresenta a distribuição dos cloretos das águas subterrâneas na Formação Caobillas, na estreita faixa de rochas vulcânicas que contorna o limite sul dos ofiolitos, onde pode se observar a normal continuidade das águas recentes dos ofiolitos nesta formação e a propagação maioritária das altas concentrações do cloreto nas restantes partes da formação.

Apesar do volume das isolinhas ser menor do que o caso anterior, ainda permite apreciar que a configuração das tendências dos contornos, neste caso, apenas para os valores acima dos $100 \mathrm{mg} / \mathrm{L}$ de cloretos, é também NE-SO e NO-SE. Tal abundância das altas concentrações dos cloretos é conseqüente com os resultados anteriores, que destacavam-na entre as águas mais velhas da região. Da análise territorial pode conceber-se que a procedência e origem da concentração das águas desta formação não estão relacionadas diretamente com as dos ofiolitos, que é o conjunto litológico imediato e de relevo mais elevado, com o qual ela contata. Mas, também não pode supor-se referência nenhuma a intrusão marinha, pela sua situação quase central no território e pelo seu reconhecido isolamento no que diz respeito aos mares, norte e sul de Cuba. Pode-se, então, afirmar que a sua procedência é das profundidades da região, acionadas pelas forças da pressão da coluna das águas de descenso.

O caso das águas na Formação Guines é o que tem a distribuição das concentrações de cloretos mais abrangente. Na Figura 67 pode se apreciar que a área coberta estende-se da costa norte à sul. Os valores de águas recentes ocupam a ampla maioria da superfície da formação, aparecendo os 


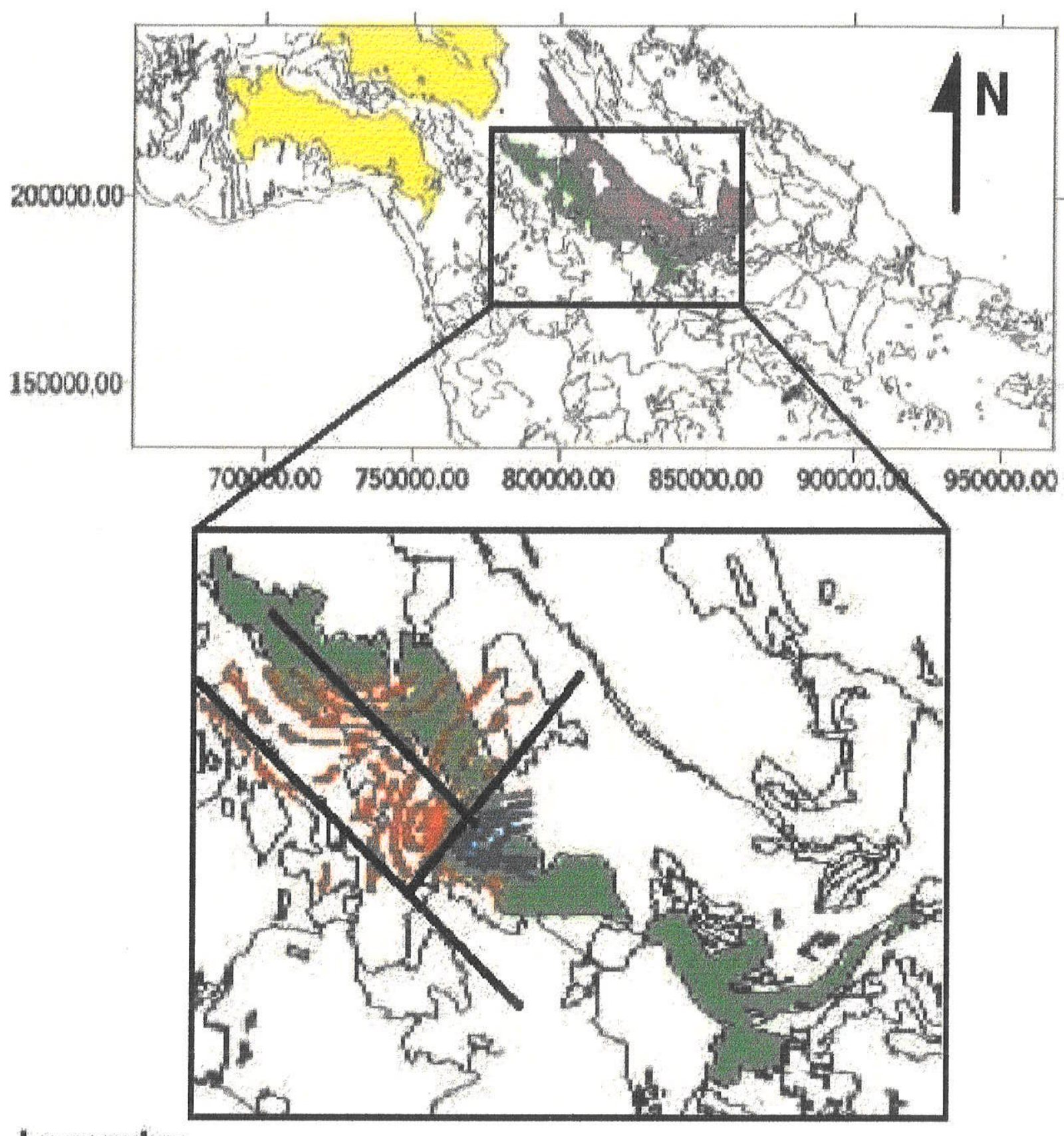

\section{Legenda :}

$\square$ Complexo Ofiolitico $\square$ Formaçăo Caobillas $\square$ Formaçăo Guines

Tendencias dos limites entre concentraçốes dos cloretos

Linhas em azul : $\mathrm{Cl}(0 \cdot 100 \mathrm{mg} / \mathrm{L}) \quad$ Linhas em vermelho: $\mathrm{Cl}(120.720 \mathrm{mg} / \mathrm{L})$

Escala : 1: 1750000

Figura 66. Distribuição dos cloretos nas águas subterrâneas que circulam pela Formação Caobillas na região de estudo. 


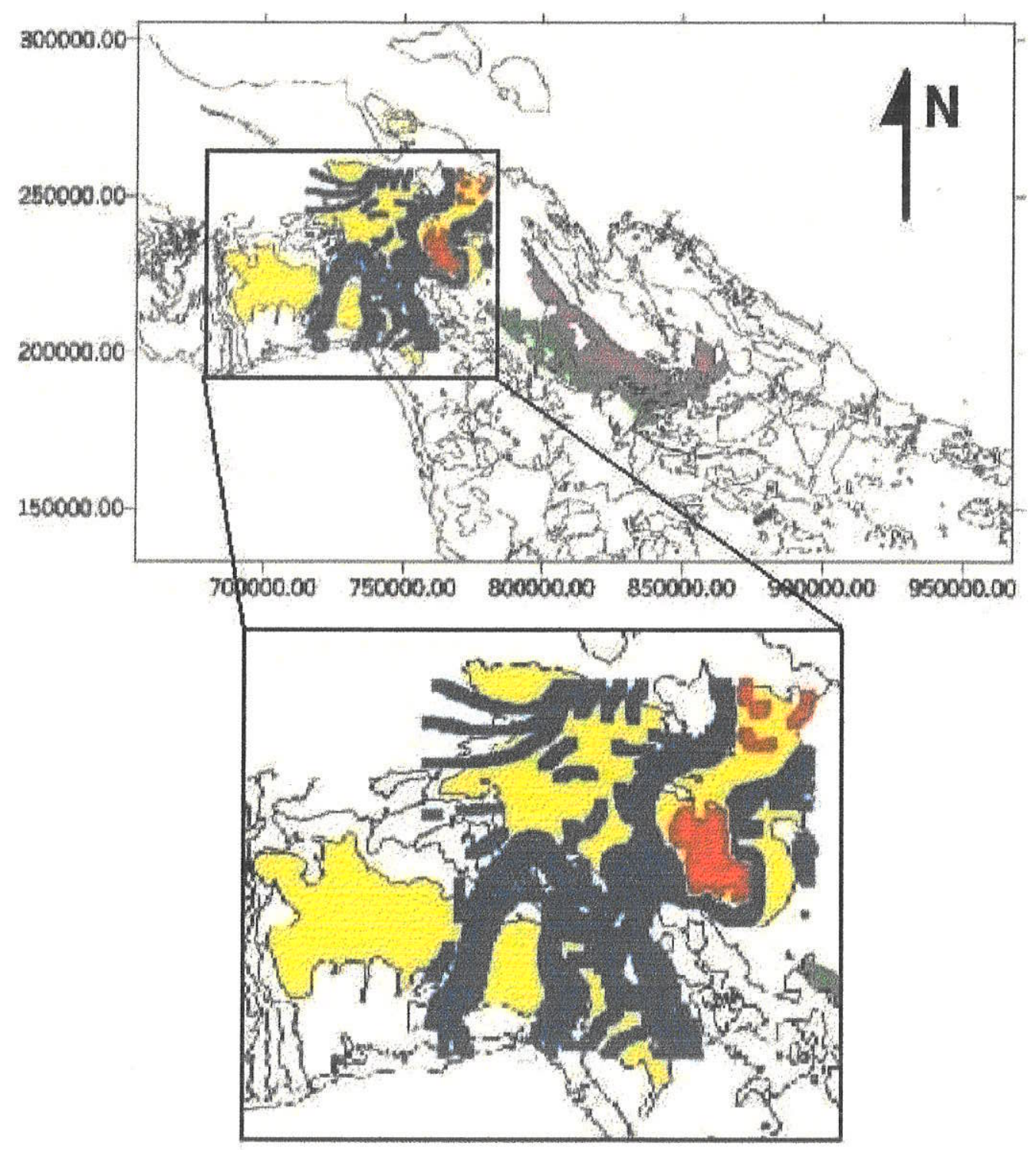

Legenda :

Complexo Ofiolitico $\square$ Formaçăo Caobillas $\square$ Formaçăo Guines

Linhas em azul : $\mathrm{Cl}(0-100 \mathrm{mg} / \mathrm{L}) \quad$ Linhas em vermelho : $\mathrm{Cl}(120-4000 \mathrm{mg} / \mathrm{L})$

Escala: $1: 1750000$

Figura 67. Detalhe da distribuição dos cloretos nas águas subterrâneas que circulam pela Formação Guines na região de estudo. 
valores de águas mais concentradas para na sua zona NE. Nesta subárea pode se destacar tendências NE-SO e NO-SE dos contornos dos limites, similares como nos casos anteriores.

Esta formação é reconhecida em Cuba como a de maior aquosidade e o resultado não a contradiz, evidenciando que o total do conjunto continua sendo uns dos maiores receptores e transmissores das águas subterrâneas de baixos conteúdos de cloretos da província.

Por estas razões, e que a formação Guines alcança até as costas norte e sul do território, se adentrando nas áreas extraterritoriais da plataforma, podendo ser admitido determinados valores altos da concentração do cloreto, como resultado da intrusão marinha para as áreas perto das costas. Mas, deve se sublinhar que nos estudos da intrusão marinha no karste cubano, a Bacia Sul de Cego, em Ciego de Ávila, tem as suas águas poucos salinas, sendo a média de $252 \mathrm{mg} / \mathrm{L} \mathrm{de} \mathrm{Cl}$, (Barros Mouriño, 1997). No entanto, as concentrações dos cloretos nesta formação alcançam até valores entre 2000 e $4000 \mathrm{mg} / \mathrm{L}$, destacados na parte inferior da referida zona NE.

As três figuras precedentes foram interpretadas a partir das representações individuais em cada formação e, por isso, isoladas nas possibilidades interpretativas de se relacionar entre si.

A Figura 68 apresenta a distribuição resultante do processamento em conjunto de todos os valores utilizados por formação, de forma individual, mantendo os mesmos intervalos já explicados. Pode se apreciar que as tendências antes evidenciadas (NE-SO e NO-SE) para os casos particulares, continuam se destacando para a distribuição total regional. $\mathrm{Na}$ parte oriental das linhas de águas recentes, pertencentes à Formação Guines, destaca-se uma nova linha de águas mais velhas, que de forma individual não surgiu para nenhuma das anteriores processadas. Aparece como nova também, ao sul da zona da Formação Guines, uma zona de águas de maior salinidade que pode ser interpretada como relacionada com intrusão marinha, por carecer de critérios que pudessem argumentar outra procedência.

Um resultado evidente desta análise é o destaque que as águas de maior salinidade apresentam-se refletindo as direções dos sistemas principais das estruturas cubanas, NE-SO e NO-SE, o que permite conceber, sob todas as considerações precedentes, que estes sistemas de estruturas preferenciais colaboram com uma drenagem de retorno à superfície de parte das águas subterrâneas que se infiltram.

O próprio resultado abre uma dúvida ante a fundamentação total do critério utilizado : Qual é o valor da concentração do cloreto que identifica se está descendo ou ascendendo a água analisada quando se coleta na superfície? $\mathrm{O}$ autor estabeleceu o critério limitante $(<100$ e $>100 \mathrm{mg} / \mathrm{L}$ de $\mathrm{Cl})$ pela fundamentação já explicada da sua correspondência com o uso das chamadas águas doces e salgadas ( $<1000$ e $>1000 \mathrm{mg} / \mathrm{L}$ de STD) para estabelecer um patamar fixo, ajustada à faixa de idades menores, e outro que admitisse até qualquer um valor máximo. 


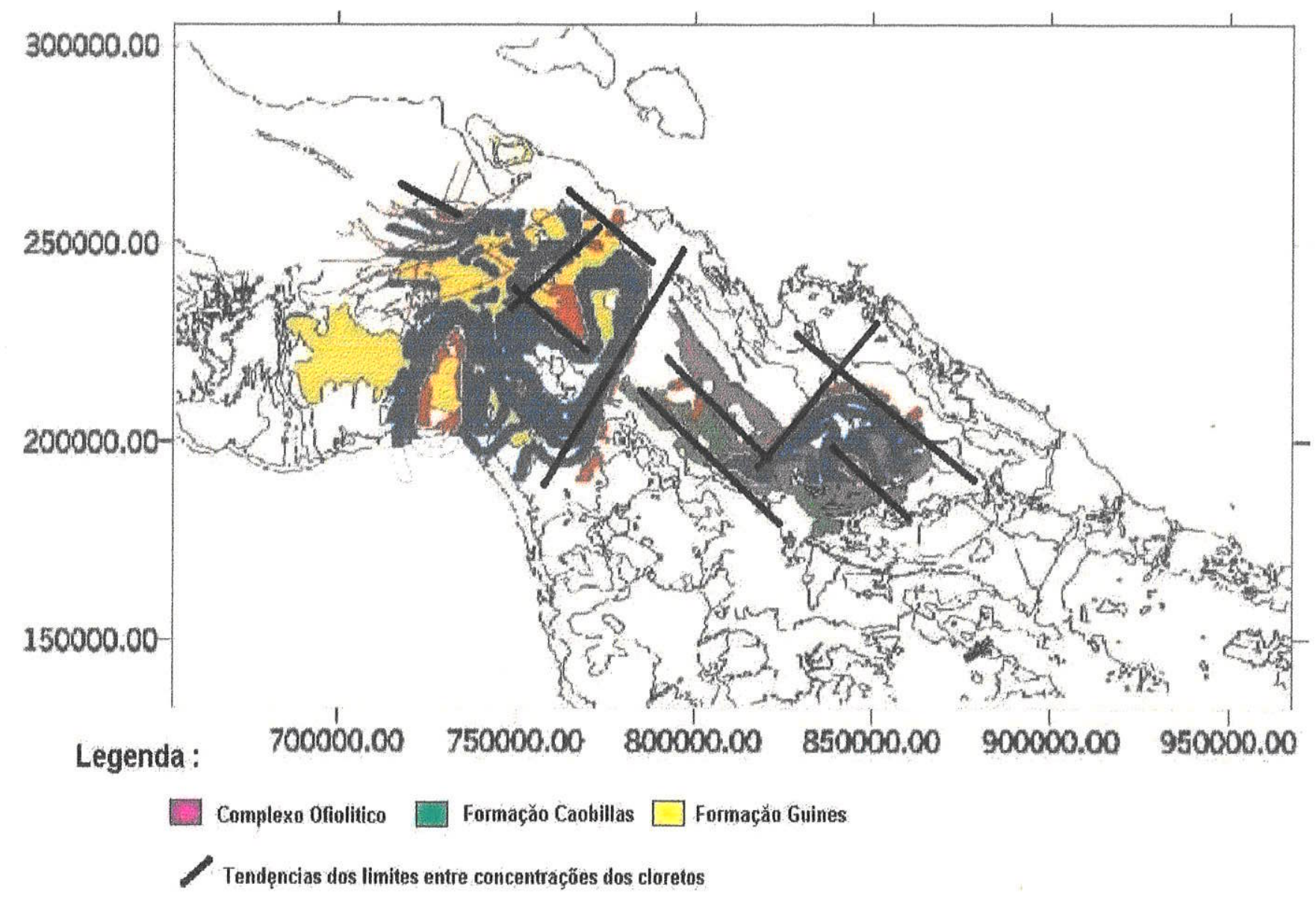

Linhas em azul : $\mathrm{Cl}(0-100 \mathrm{mg} / \mathrm{L}) \quad$ Linhas em vermelho : $\mathrm{Cl}(120-3620 \mathrm{mg} / \mathrm{L})$

Escala: 1:1750 000

Figura 68. Interpretação das configurações apresentadas pela distribuição das concentrações dos cloretos nas formações geológicas processadas. 
Assim limitados, o fato exato que o mencionado valor estivesse entre 80 ou 320 $\mathrm{mg} / \mathrm{L}$ de $\mathrm{Cl}$, por citar qualquer uma possibilidade, repercute apenas nas dimensões das áreas recentes/velhas, mas não na essência da interpretação nem a relação evidenciada entre um e outro tipo de concentração apresentada.

A distribuição dos cloretos nas águas do Complexo Ofiolítico caracteriza o maciço como um receptor das precipitações que sobre ele caem, além de identificar-lo como um efêmero condutor de águas subterrâneas para o território circundante, convertendo-o, pela sua altura sobre o relevo $(\sim 70 \mathrm{~m}$ de altitude), em uma zona de recarga que gera parte das forças que contribuem com o equilíbrio do movimento do sistema hidrogeológico regional.

Devido à posição central no território, unida a sua configuração estreita e alongada, diretamente ao lado dos ofiolitos, são estabelecidas condições hidrogeológicas particulares para a Formação Caobillas, que lhe permite servir de receptor e transmissor das águas de maior salinidade, ou as mais velhas, provenientes das profundidades da região de estudo. Se bem que as zonas fraturadas das estruturas podem interceptar parte das águas que descem e facilitar o seu retorno à superfície, tudo parece indicar, pela abundância e distribuição de águas com alto conteúdo de cloreto na maior parte da área da formação, que toda a espessura dela funciona como um grande plano de fratura que possibilita o retorno das águas à superfície. A explicação precedente caracteriza o processo predominante, sem desconsiderar as partes superficiais da formação onde devem operar também processos de recargas ao sistema, mas a sua conotação não é relevante.

No caso da Formação Guines, cuja extensão ocupa as partes inferiores do relevo do território,como evidência de abundância de águas recentes e a morfologia das correntes superficiais que por ela circulam, funciona como recarga por si mesma e como receptor de parte das drenagens subterrâneas provenientes das correspondentes vertentes das formações de alturas superiores que constituem o Arco Vulcânico e o Complexo Ofiolítico.

Pode ser visto da Tabela 11 e a Figura 62 que as restantes formações não analisadas ao detalhe, estão compreendidas dentro das circunstâncias extremas apresentadas. Como caracterização geral, as formações dos ofiolitos, granitos e granodioritos de Camaguey, Contramaestre, Guines e Vila Roja funcionam principalmente como zonas de recarga da região e as formações granodioritos de Lãs Tunas e Caobillas funcionam como drenagem de retorno de parte das águas mais velhas, equilibrando uma parte das pressões do sistema. O caso da Formação Vertientes não se enquadra em nenhum dos citados, apesar de que as suas águas agrupam-se entre as velhas devido a sua composição predominantemente argilosa, pouco aqüifera, pode basear a sua alta concentração a uma circulação mais lenta e até em parte isolada dos restantes mecanismos do sistema da região ou, também, com certa influencia derivada da sua proximidade com a Formação Caobillas. 


\section{Considerações sobre as águas minerais cubanas, em particular de Cuba Centro-Oriental, e as relacionadas com as jazidas de petróleo na região de estudo.}

O relacionar as águas minerais da região de estudo com as interpretações até aqui expressas e avaliar como parte delas pertencem ao sistema integral da região é outro dos alvos principais da pesquisa.

Um dos aspetos que não podem ser desconsiderados dentro do contexto das águas minerais medicinais, são as águas provenientes das jazidas de petróleo devido às suas propriedades medicinais, principalmente pelo seu teor de enxofre. Em particular existem manifestações no subsolo da parte ocidental da região de estudo, província de Ciego de Ávila, que dão lugar a jazidas de petróleo de diferentes produtividades (Díaz, L. \& Díaz A., 1999; Capote, 1999).

No capítulo anterior confirmou-se a possibilidade de interpretar a evolução das águas subterrâneas através da distribuição das concentrações dos cloretos. A extrapolação das conceições aplicadas às águas subterrâneas no caso das águas minerais, além de corroborar como parte das restantes águas subterrâneas, fundamenta um caráter de universalidade ao processo da Cloretogênese.

A Figura 69 apresenta o Diagrama de Piper e a correlação gráfica da concentração dos cloretos com os Sólidos Totais Dissolvidos (STD) das águas minerais medicinais de Cuba e das águas salinizadas provenientes das jazidas de petróleo da região de estudo. Nela a correlação mantem-se para todas ás águas analisadas, mesmo que para as restantes águas subterrâneas comuns. O valor médio da concentração de cloretos e salinidade do mar é apresentado como uma necessária e conhecida referência em consideração aos altos valores utilizados. Especial referência foi dada as águas minerais de Elguea, fonte ao NE da vizinha região de Cuba Central, província de Matanzas, por ser o balneário em exploração com as águas de maior salinidade de Cuba (30 000 $\mathrm{mg} / \mathrm{L}$ de $\mathrm{Cl}$ ), e evidentemente na figura, maior que a salinidade do mar. As restantes águas minerais cubanas têm os seus valores abaixo da do mar, mas, pela demonstrada correlação Cl/STD, sujeitas ao constante processo da cloretogênese, o que permite avaliar as suas correspondentes idades, incluindo aquelas relacionadas com o petróleo.

Conseqüentemente, pode se generalizar e afirmar também, que as águas de maior salinidade de Cuba são aquelas relacionadas com as jazidas de petróleo.

A Tabela 12 apresenta os resultados das idades das águas minerais de Cuba, calculadas pelo MCC e correlacionadas com as respectivas idades estratigráficas que representam os valores em anos. Pode ser visto que todas as águas mais velhas se relacionam com o Paleógeno (Elguea e Menendez), as de idade relativamente média, com o Neógeno (Ciego Montero, P.Figueredo, Veracruz, El Azufre e Camujiro), ambas as duas pertencentes ao Terciário, e as 10 restantes fontes, as mais jovens, relacionam-se com o Pleistoceno, Quaternário. 


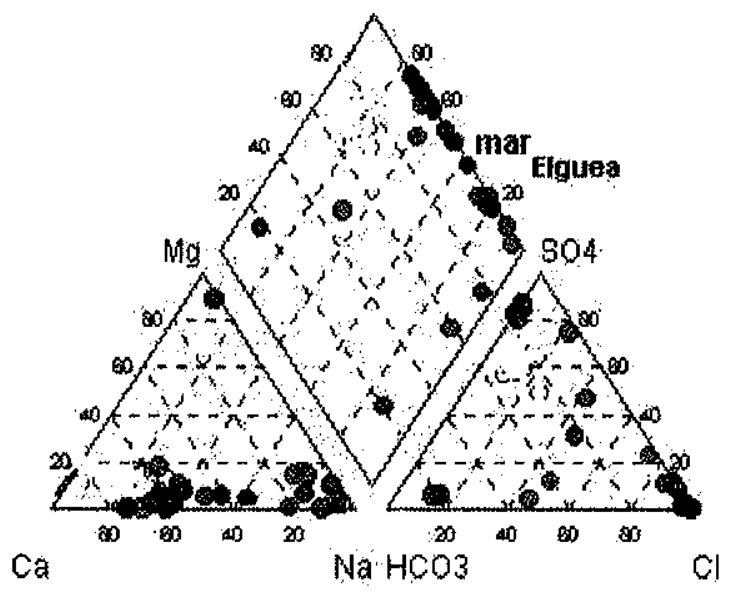

Legenda:

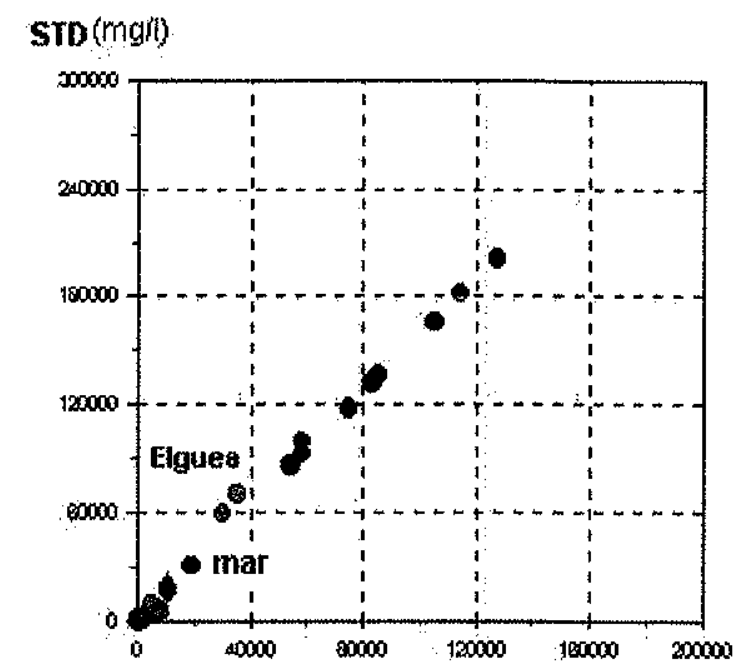

* Mananciais de áģuas minerais da regiăo de estudo

ol (mgl)

- Outros mananclais de aguas minerais de Cuba

- Pontos de âguas relacionadas com jazidas de petrôleo da regiăo de estudo

- Agua de mar

Figura 69. Diagrama de Piper e Correlação gráfica da concentração dos cloretos com os Sólidos Totais Dissolvidos (STD) das águas minerais medicinais de Cuba e das águas salinizadas provenientes das jazidas de petróleo da região de estudo.

TDS

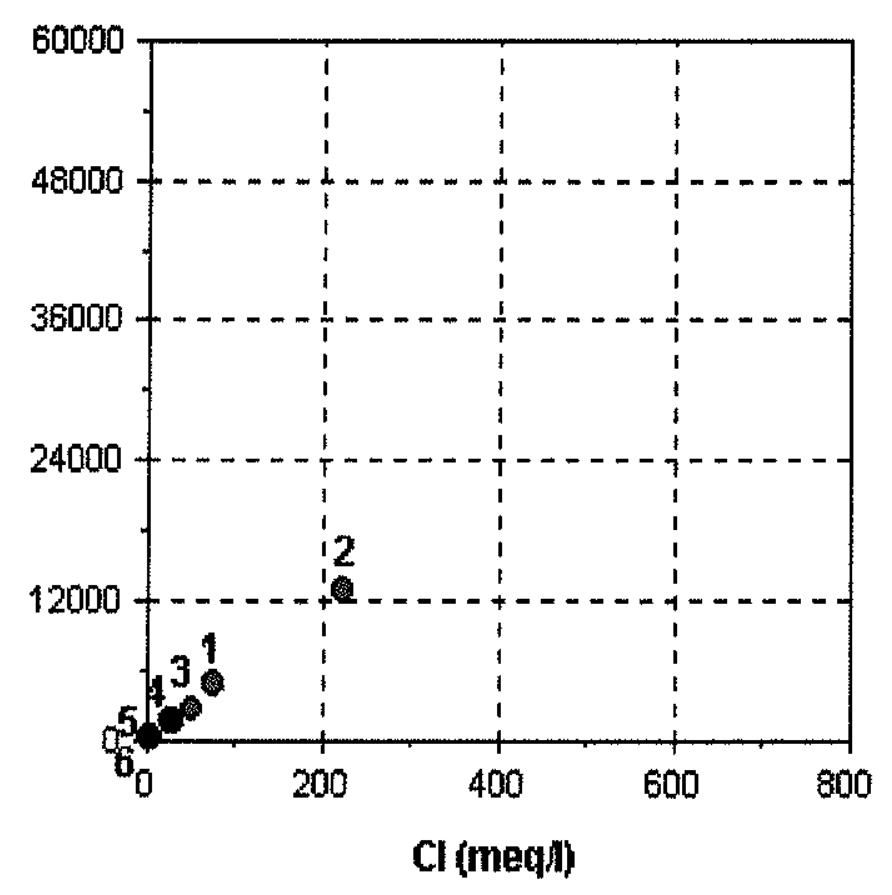

\section{Legenda :}

Tipo de água mineral :

1 El Azufre

2 Veracruz Agua mineral medicinal

3 Camujiro

4 Chaparra

5 Lesca

6 Peña Azul

Agua mineral natural

(engarrafada)

Figura 70. Gráfico de correlação CI/STD especificamente para os tipos de águas minerais reportados na região de estudo. 
Tabela 12 Idades das águas minerais medicinais cubanas calculadas pelo Método de Concentração do cloreto em milhões de anos com a sua equivalência nas idades estratiaráficas.

\begin{tabular}{|c|c|c|c|c|}
\hline $\begin{array}{c}\text { Fonte de água } \\
\text { mineral }\end{array}$ & Província & Cl(mg/L) & $\begin{array}{c}\text { Idade(Ma) } \\
\text { MCC }\end{array}$ & Idade Estratigráfica \\
\hline San Diego & Pinar del Rio & 15 & 0,023 & Plistoceno \\
\hline Bermejales & Pinar del Rio & 60 & 0,09 & Plistoceno \\
\hline S.M. Rosario & C. Habana & 313 & 0,46 & Plistoceno \\
\hline Menendez & Matanzas & 35000 & 53 & Paleógeno \\
\hline Elguea & Matanzas & 30000 & 45 & Paleógeno \\
\hline Ciego Montero & Cienfuegos & 1067 & 1,6 & Neógeno \\
\hline Arimao & Cienfuegos & 523 & 0,78 & Plistoceno \\
\hline P.Figueredo & Cienfuegos & 4608 & 6,9 & Neógeno \\
\hline La Bija & Sancti Spiritu & 386 & 0,57 & Plistoceno \\
\hline El Guije & Sancti Spiritu & 179 & 0,27 & Plistoceno \\
\hline El Cedron & Santiago de Cuba & 280 & 0,42 & Plistoceno \\
\hline Veracruz & Ciego de Avila & 7774 & 11,66 & Neógeno \\
\hline El Azufre & Ciego de Avila & 2795 & 4,19 & Neógeno \\
\hline Tamarindo & Ciego de Avila & 193 & 0,28 & Plistoceno \\
\hline Camujiro & Camaguey & 1327 & 1,99 & Neógeno \\
\hline Paso de Lesca & Camaguey & 28 & 0,042 & Plistoceno \\
\hline Cana Azul & Camaguey & 11 & 0,017 & Plistoceno \\
\hline Lasta & Plistoceno \\
\hline
\end{tabular}

Fonte : Valdés, 1990. Controles de trabalho, registro pessoal. 
Resulta compreensivel, na comparação prática, que as idades das águas subterrâneas, agora as minerais, sejam também mais jovens que a idade a qual Cuba estava geologicamente constituída (Neoautóctone), ainda que o território cubano tenha ficado totalmente emergido, com a sua configuração atual, no Holoceno (Furrazola et al,1997).

No caso particular das águas minerais da região de estudo, como é detalhado na Figura 70, mantêm a mesma correlação. Pode ser visto que as águas de maior concentração são as medicinais pertencentes às fontes Veracruz, El Azufre e Tamarindo, e as de menor concentração aquelas utilizadas para bebida engarrafada. Se forem comparados estes valores menores da concentração do cloreto com as restantes águas subterrâneas comuns, resulta justificado o predomínio do tipo bicarbonatado, devido sua baixa salinidade $(<2$ $000 \mathrm{mg} / \mathrm{L}$ de STD), em comparação com as outras águas medicinais, nas quais predomina o tipo cloretado, quando são maiores os referidos valores de salinidade.

As relações entre as idades das águas minerais e as suas procedências, segundo as formações geológicas pelas quais circulam, aparecem representadas graficamente na Figura 71 . A generalização da figura permite apreciar que as águas relativamente jovens guardam proporção com a faixa das idades das correspondentes águas subterrâneas que circulam pelos mesmos conjuntos litológicos. Aparecem nitidamente alheios da referida equivalência Veracruz e Camujiro. Uma análise particularizada para este fim nos respectivos relatórios técnicos dos estudos hidrogeológicos de cada um permite (Vide descrições dos pontos no Capítulo VI. Amostragem):

1) No caso Veracruz, relaciona a profundidade da entrada de água aos 166 $\mathrm{m}$ ao cortar uma falha, que logo começa subir até jorrar na superfície (N.E. : $+9,0 \mathrm{~m}$ ). Mas, o perfil geológico da situação do poço (Rodriguez, 1994) concebe-se a presença da formação Caobillas, cortada pela mesma falha captada pelo poço, a qual passa por esta, atravessando as formações da cobertura cenozóica até chegar à superficie. Logo, é evidente que 0 aqǘf́ro que aporta as águas salinizadas do poço Veracruz, pode também pertencer, em grande parte, à Formação Caobillas.

2) No caso Camujiro, o relatório menciona que as águas ascendem também por pressão (N.E. $=+0,61 \mathrm{~m}$ ) a partir de sistemas de gretas, fraturas e contatos dentro do complexo ígneo intrusivo, que chegam desde profundidades em volta aos $200 \mathrm{~m}$, constituídas por conjuntos litológicos do Arco Vulcânico do Cretáceo, Formação Piragua, até a superfície (Cascaret, 1991). Mas, a literatura geológica cubana tem estabelecido certo paralelismo entre a Formação Piragua e a Formação Caobillas, enquanto as suas respectivas idades e, pela similaridade em algumas características litológicas, principalmente de origem vulcânico, sugerem a possibilidade de existência de relações entre ambas duas, sendo dificultoso estabelecer os seus limites em algumas localidades (Furrazola et al,1997). Logo, também não pode se desconsiderar que nestas profundidades participe também a Formação Caobillas na circulação das correspondentes águas subterrâneas que alimentam a Fonte de água mineral de Camujiro. 
11.0
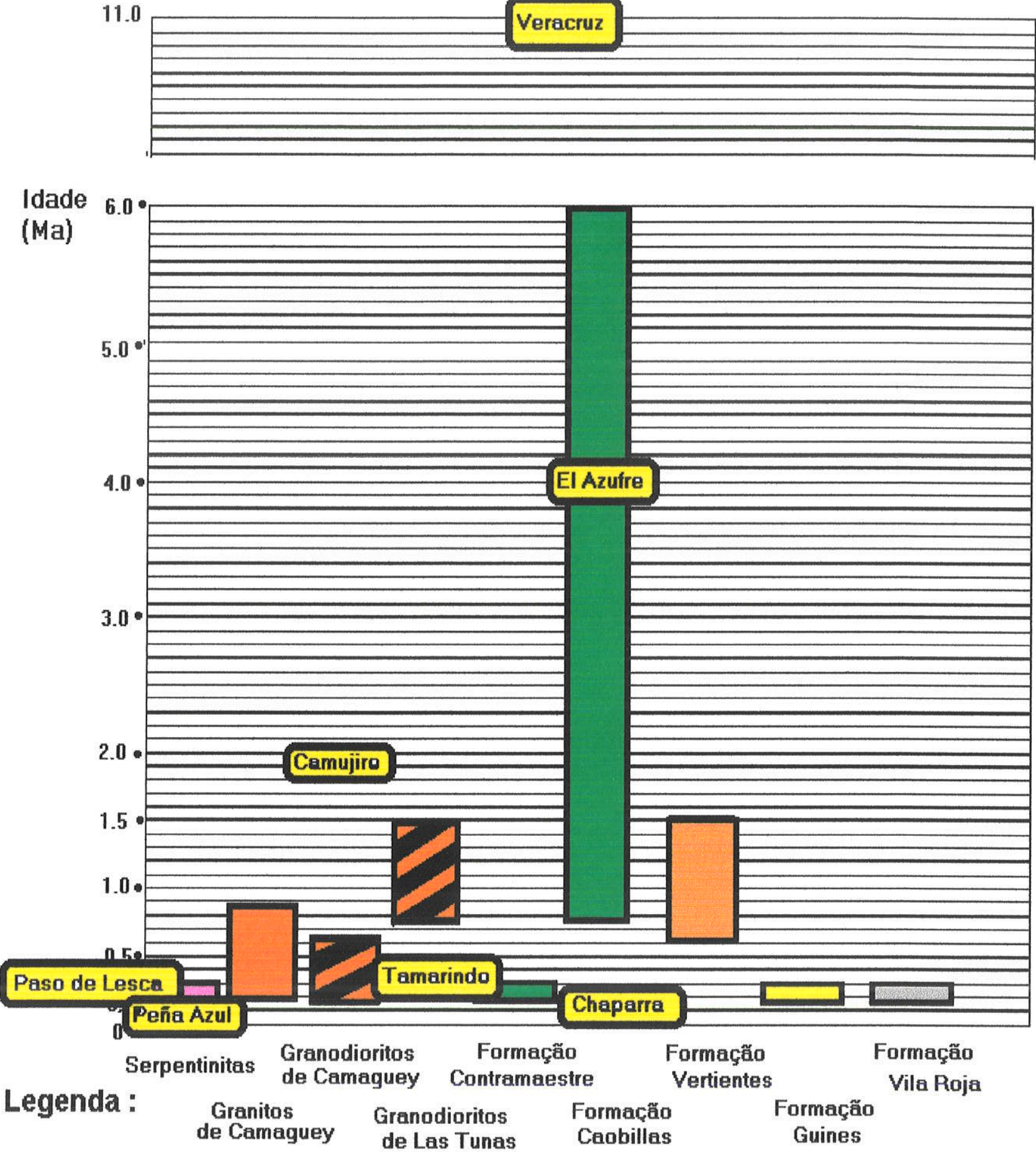

Manancial de água mineral relacionando a sua idade calculada pelo MCC com a idade das águas subterrâneas da sua correspondente litologia reportada.

Figura 71. Representação gráfica da relação de idades dos mananciais de águas minerais com as idades das águas subterrâneas que circulam pelas litologias correspondente reportadas nos respectivos estudos hidrogeológicos. 
A procedência das águas de El Azufre é inquestionável da Formação Caobillas, que também jorra com pressão, vazando $240 \mathrm{~L} / \mathrm{min}$ continuadamente desde 1969 a partir da profundidade de $165 \mathrm{~m}$ (Rodriguez, 1992). Esta fonte é um poço da prospecção do petróleo, abandonado pela sua improdutividade para o fim proposto, pelo qual a gênese das suas águas é relacionada às jazidas de hidrocarbonetos.

Associando os elementos antecedentes fica evidenciado que as águas minerais mais concentradas, velhas, da região de estudo, estão retidas sob pressão e relacionadas com Formação Caobillas, a qual foi considerada que funcionava como drenagem do retorno de uma das partes das águas subterrâneas que desciam como infiltradas, desviando-as da continuação do seu processo natural da Cloretogênese. Como mais um elemento a considerar, o fato de relacionar-se as águas minerais de El Azufre com jazidas de petróleo dentro da Formação Caobillas, abre o campo à possibilidade que as águas de Veracruz, mais salinizadas e procedente da mesma formação, tenham relação também com jazidas similares.

Como no texto todo sempre foram esclarecidas e analisadas as respectivas distribuições das concentrações sob a condição da apresentação superficial das águas coletadas e considerando neste ponto da pesquisa, a necessidade de precisar o comportamento das águas existentes mais profundas e a sua relação com as de menor profundidade, se recorreu às informações das pesquisas de petróleo na área de estudo. Estes dados mantem a certeza da sua procedência da profundidade de amostragem, sem mistura com as restantes mais superficiais.

A Tabela 13 apresenta a informação processada, a qual registra o cálculo das idades e a sua equivalência estratigráfica, mesmo como se procedeu com as águas minerais de Cuba. Neste caso evidencia-se uma correspondência significativa entre as idades das formações litológicas donde procedem as águas e as suas idades calculadas pelo MCC. Precisa ser indicado que não podem se estabelecer os mesmos critérios no que diz respeito às idades da águas minerais e a idade de formação da liha de Cuba, porquanto a idade de formação das jazidas de petróleo é associada à das Unidades Oceânicas (PréJurassica). Nesse sentido pode se dizer que estas águas relacionadas com petróleo são quase tão antigas quanto as formações que as contêm, podendo considerar-se, à luz destes resultados, que representam águas singenéticas, mas que não existem elementos sólidos demais para considerar que já não circulam. Algumas podem estar vindo de maiores profundidades pelos mesmos mecanismos daquelas que alcançam a superfície do território.

Pertencem especificamente à região de estudo, província de Ciego de Ávila, os pontos citados como jazidas Pina e Agustín na Tabela 13. Os restantes pontos pertencem a outras regiões de Cuba. A Figura 72 apresenta os poços de águas minerais de Ciego de Ávila (Veracruz, El Azufre E Tamarindo) e aqueles da jazida Pina que proporcionaram parte dos dados processados. 
Tabela 13 Idades das águas subterrâneas altamente salinizadas relacionadas com as jazidas cubanas de petróleo, calculadas pelo Método de Concentração de cloreto em milhões de anos com a sua equivalência nas idades estratigráficas.

\begin{tabular}{|c|c|c|c|c|c|c|c|c|}
\hline Jazida & Poço & Prof(m) & $\begin{array}{c}\text { Idade } \\
\text { geológica }\end{array}$ & Formação & $\mathrm{Cl}(\mathrm{mg} / \mathrm{l})$ & STD $(\mathrm{mg} / \mathrm{L})$ & Idade(Ma) MCC & Idade Estratigráfica \\
\hline PINA & 2 & 860 & $\mathrm{~K}_{2}^{\mathrm{cp}}$ & Hilario & 50342 & 91171 & 75 & Cretáceo Sup. \\
\hline PINA & 2 & 965 & $\mathrm{~K}_{2}^{\mathrm{cp}}$ & Hilario & 74530 & 118101 & 112 & Cretáceo Inf. \\
\hline PINA & 27 & 853 & $\mathrm{~K}_{2}^{\mathrm{cp}}$ & Hilario & 83114 & 133925 & 125 & Cretáceo Inf. \\
\hline PINA & 27 & 970 & $\mathrm{~K}_{2}{ }^{\mathrm{cp}}$ & Hilario & 85200 & 137075 & 128 & Cretáceo Inf. \\
\hline PINA & 49 & 1185 & $K_{1}^{a-a l}$ & Mataguá & 82981 & 132167 & 124 & Cretáceo Inf. \\
\hline PINA & 111 & 875 & $\mathrm{P}_{2}{ }^{1}$ & Loma Iguará-Zaza & 57854 & 92709 & 87 & Cretáceo Sup. \\
\hline PINA & 135 & 1054 & $K_{1 a l}{ }^{\sup }-K_{2}{ }^{t}$ & Seibabo? & 58141 & 100292 & 87 & Cretáceo Sup. \\
\hline CRISTALES & 123 & 1017 & $\mathrm{~K}_{2}^{\mathrm{cp} 1}$ & Hilario & 104856 & 166538 & 157 & Jurássico Sup. \\
\hline AGUSTIN & 8 & 1389 & $\mathrm{~K}_{2}{ }^{\mathrm{cp}}$ & Hilario & 127597 & 201197 & 191 & Jurássico Inf. \\
\hline GUAYACANES & 10 & 1107 & $\mathrm{~K}_{2}^{\mathrm{cp}}$ & Hilario & 54145 & 86479 & 81 & Cretáceo Sup. \\
\hline JATIBONICO & 69 & 436 & $\mathrm{~K}_{2} \mathrm{cp}$ & Hilario & 18718 & 31188 & 28 & Paleogeno \\
\hline JATIBONICO & 78 & 4120 & $\mathrm{~K}_{1}^{\mathrm{a}-\mathrm{cn}}$ & Mataguá & 114150 & 182370 & 171 & Jurássico Med. \\
\hline
\end{tabular}

Fonte : Díaz,L.,Díaz A. 1999 Informe proyecto 2121Recuperación Mejorada de Petróleo del yacimiento Pina. Archivo CEINPET. 


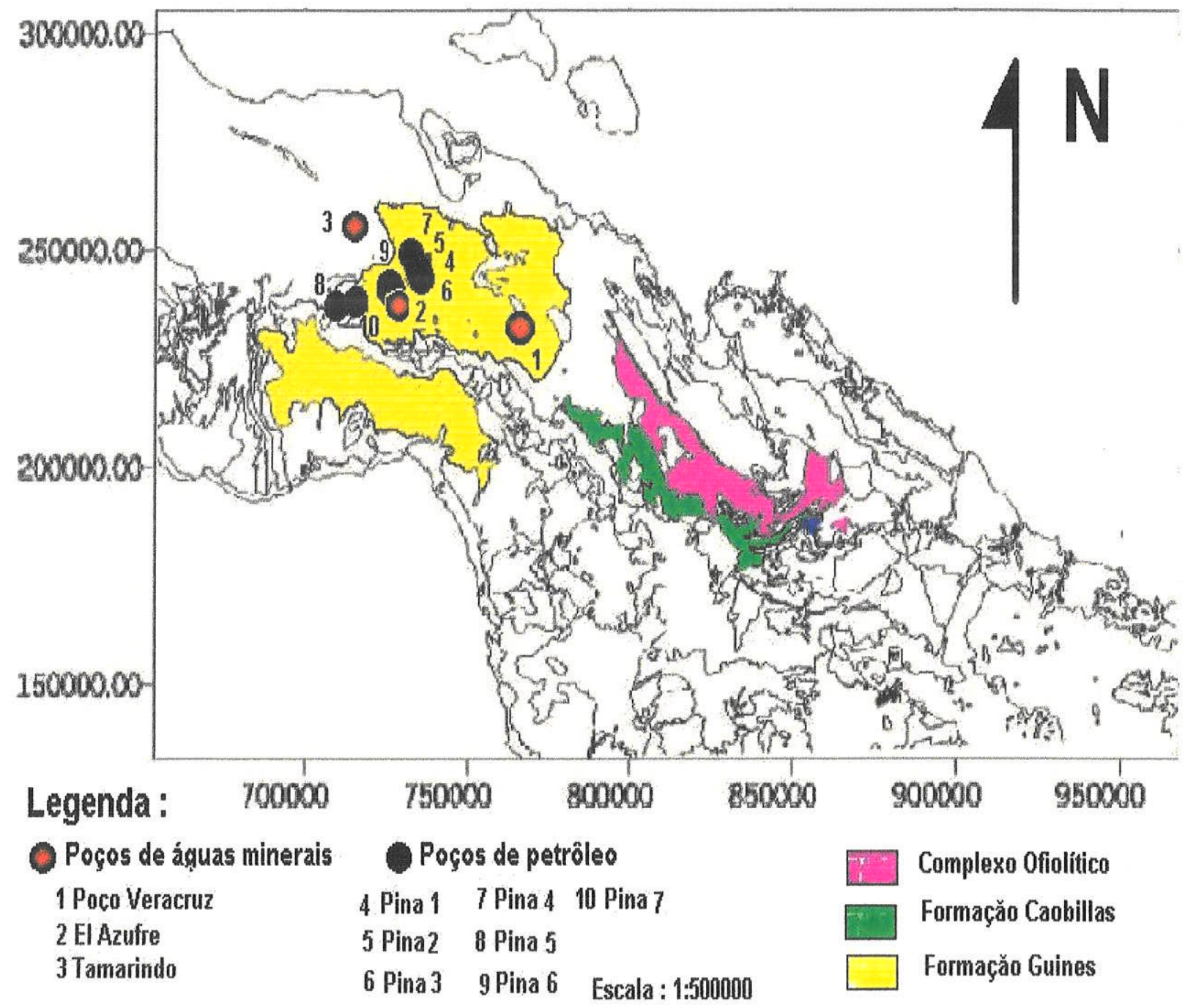

Figura 72. Distribuição na província de Ciego de Avila dos poços de águas minerais medicinais e dos poços de petróleo relacionados com a jazida petrolífera Pina da parte ocidental da região de estudo. 
Pode ser notado que todos os poços estão inicialmente situados na Cobertura Cenozóica ainda que os seus extremos finais tenham profundidades diferentes para cada grupo considerado (Menos de $200 \mathrm{~m}$ para as águas minerais e mais de $800 \mathrm{~m}$ para os provenientes do petróleo).

A Figura 73 apresenta dois mapas, A (o mesmo já analisado na Figura 68) e, B, resultado do processamento para as águas de alta salinidade provenientes do petróleo. Pode apreciar-se na comparação que em ambos a tendência dos lineamentos dos limites entre os valores extremos da concentração do cloreto mantêm estreita relação com as estruturas cubanas. A superposição dos lineamentos de B para A, permite um pouco particularizar que a circulação e certa acumulação das águas altamente salinizadas, de profundidades superiores aos $800 \mathrm{~m}$, estão relacionadas e controladas pelo sistema de direções da Falha La Trocha, a estrutura mais ocidental da região de estudo, ou considerada também pela sua atividade presente, entre as de "longa vida", do Cretáceo (Carbeny, 1999).

No caso do sistema de águas de menor salinidade do mapa $A$, que chegam aflorar à superfície do território, parecem controladas mais favoravelmente pelo conjunto de estruturas relacionadas com os "lineamentos neotectônicos ativos", do Paleógeno (Carbeny, 1999).

Nesta análise, pode especificar-se que as águas do plano mais profundo não significam que alcançaram sua concentração finalmente definitiva, pois o fato de corresponder com esse nível de coleta, não contradiz que venham de profundidades maiores, e por enquanto, com maior salinidade.

A Figura 74 apresenta uma visualização do sentido físico espacial dos dois níveis de referências utilizados. Evidentemente, apenas permite constatar o vazio da necessária informação para estabelecer o nexo entre ambos os planos e a situação verdadeira abaixo do plano até hoje mais profundo analisado do ponto de vista hidrogeológico regional.

A variabilidade das concentrações de cloretos e a sua distribuição espacial, evidenciadas na sua relação com sistemas de estruturas ativas de diferentes períodos de existências, permite estender mais um pouco os exemplos sobre a participação do meio geológico nos processos de formação das águas subterrâneas. Neste sentido, pode se apreciar que o limite inferior de circulação e acumulação das águas subterrâneas, refletidas nas suas respectivas salinidades, ainda não está ao alcance técnico, mas também não longe demais. Pode se afirmar, à luz de todos estes resultados, que a dependência de fatores geológicos espaciais e temporais na evolução das águas subterrâneas, como são as estruturas e as suas atividades, transforma a participação do chamado meio sólido geológico num caráter dinâmico, enriquecendo, para a Hidrogeologia, as análises baseadas apenas no que permitia a porosidade para a circulação ou a petrografia para a salinidade das águas subterrâneas. 


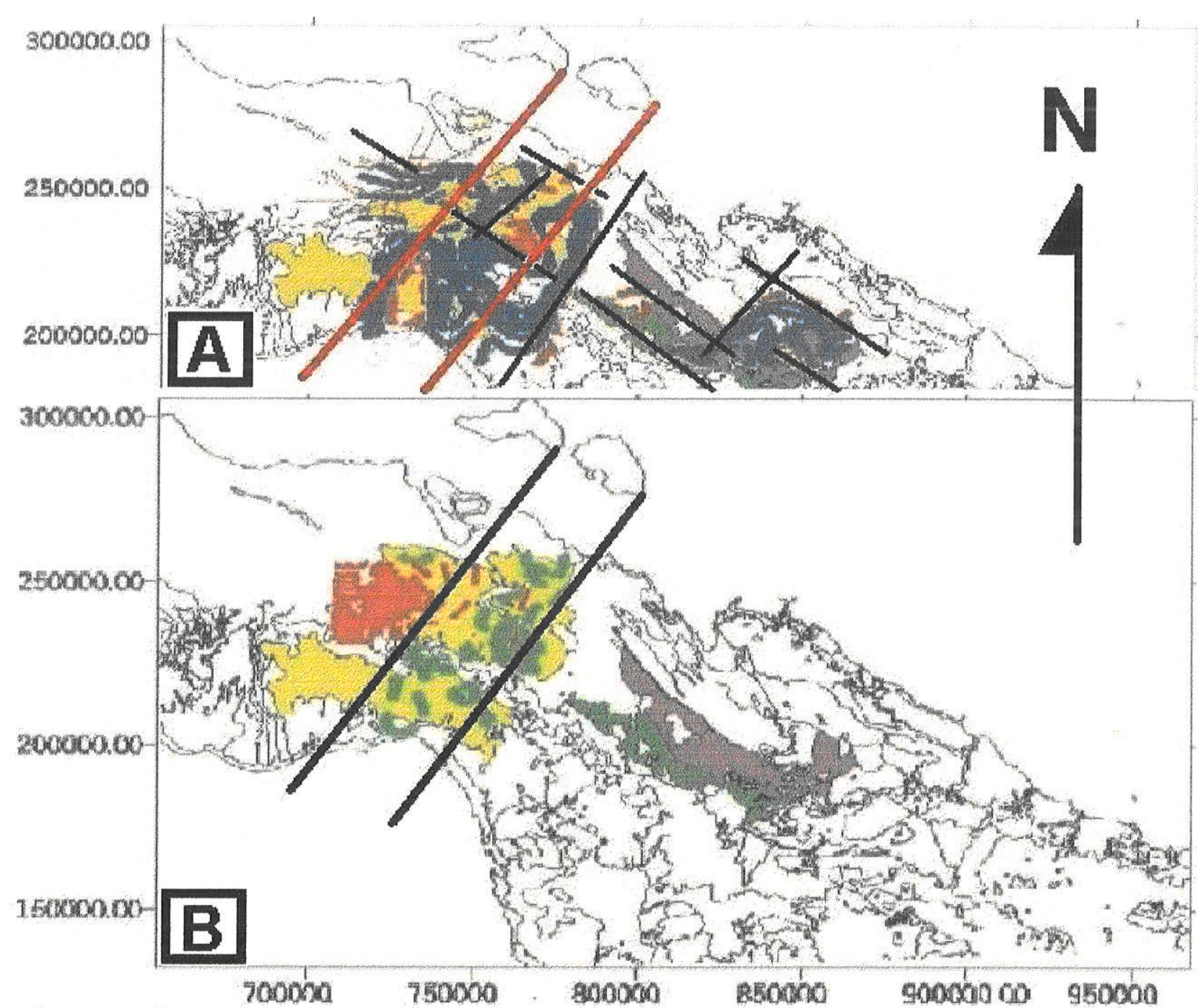

Legenda : A Distribuiçăo das concentraçöes de cloretos com os pontos medidos na superficie do terrritório.

$0-100 \mathrm{mg} / \mathrm{L} \mathrm{Cl} \longrightarrow 120-3000 \mathrm{mg} / \mathrm{L} \mathrm{Cl}$

Tendęncias dos limites entre as concentraçöes
extremas dos cloretos

Superposiçăo das tendẹcias interpretadas em B

B Distribuiçăo das concentraçöes de cloretos com os pontos medidos nas profundidades maiores dos $600 \mathrm{~m}$.

$120-5000 \mathrm{mg} / \mathrm{L} \mathrm{Cl} \quad 10000-100000 \mathrm{mg} / \mathrm{L} \mathrm{Cl}$

Tendęncias dos limites entre as concentraçốes
extremas dos cloretos

Complexo Ofiolítico

Formaçăo Caobillas

Formaçăo Guines

Escala $1: 1750000$

Figura 73. Mapas comparando as diferentes distribuições das concentrações do cloreto para os casos de: A (os valores para os pontos medidos na superfície do terreno) e B (os valores para os pontos medidos nas profundidades nos poços das jazidas de petróleo). 


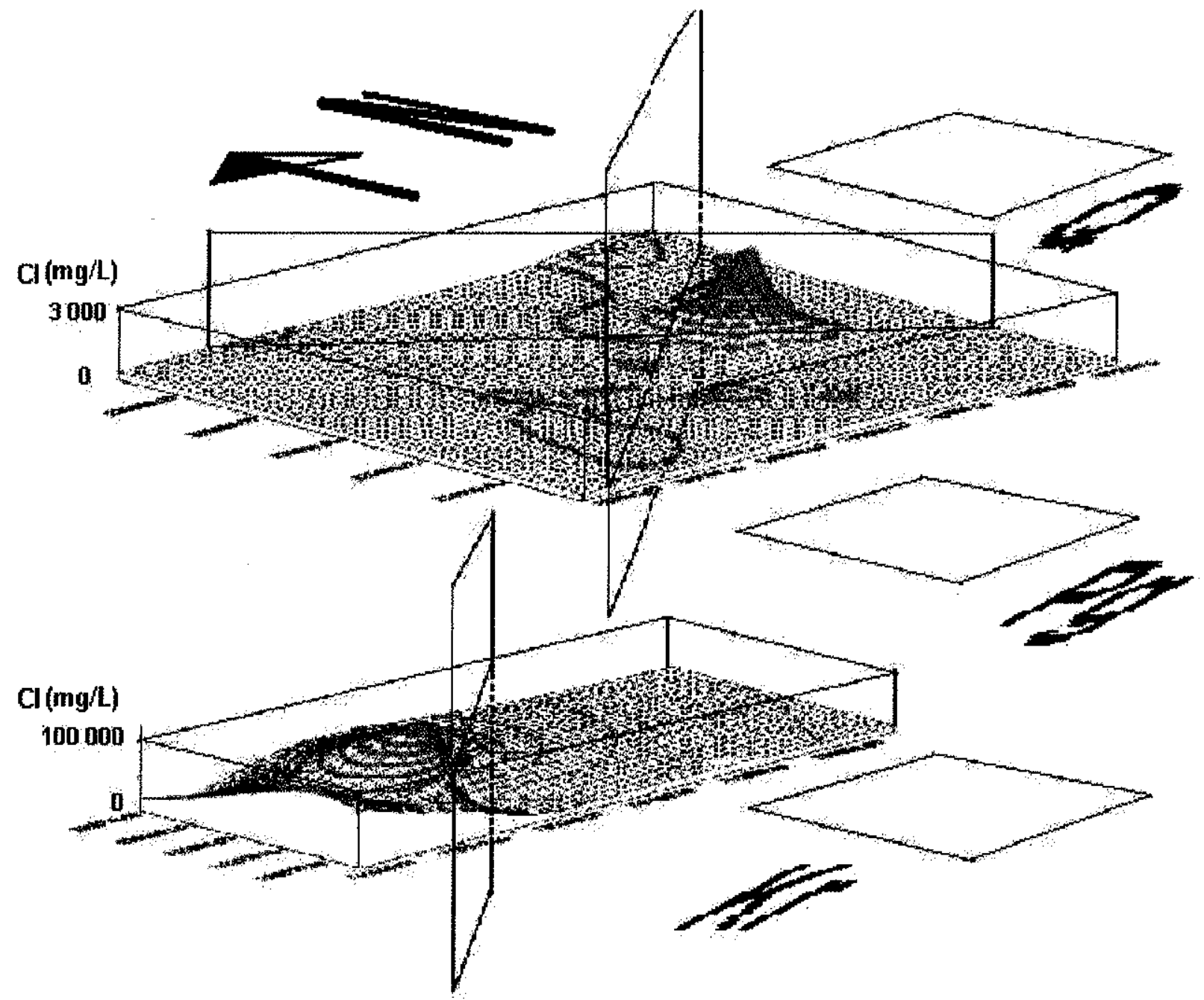

Legenda:

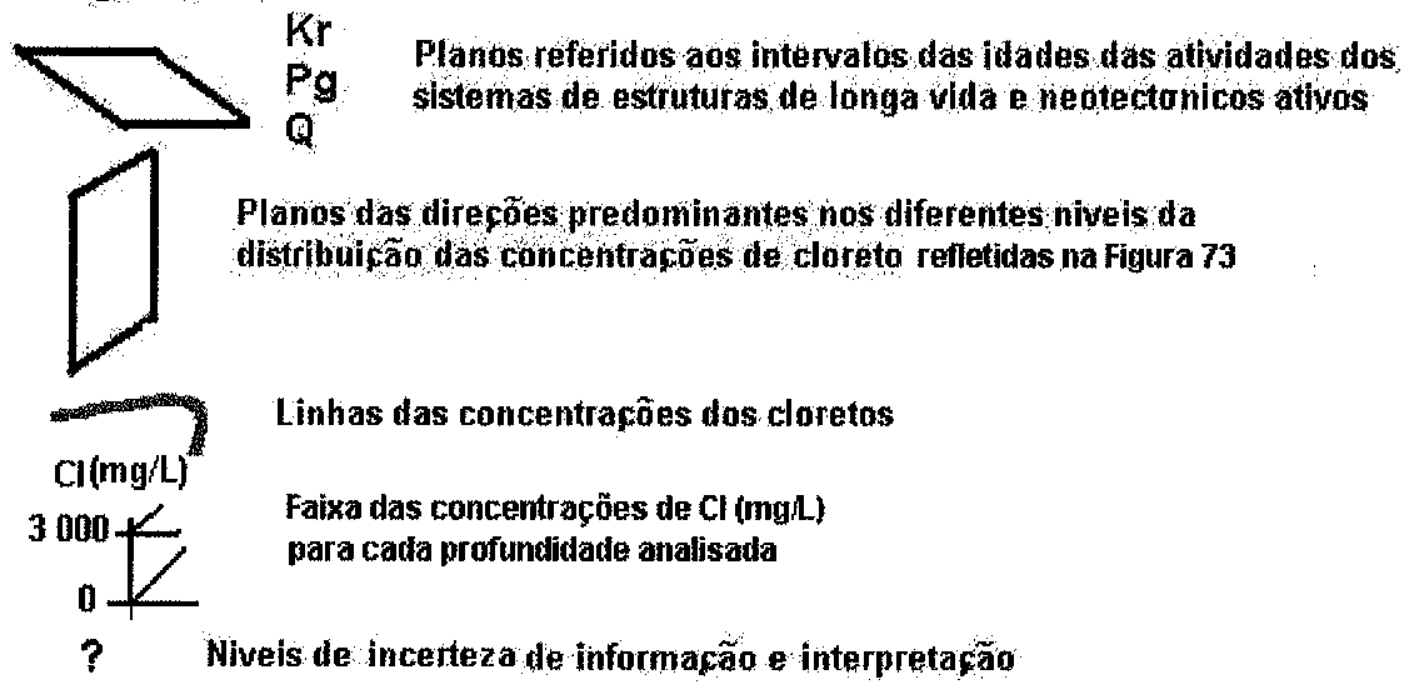

Figura 74. Representação em relevo da distribuição das concentrações dos cloretos separados nos dois diferentes níveis de profundidades processados. 


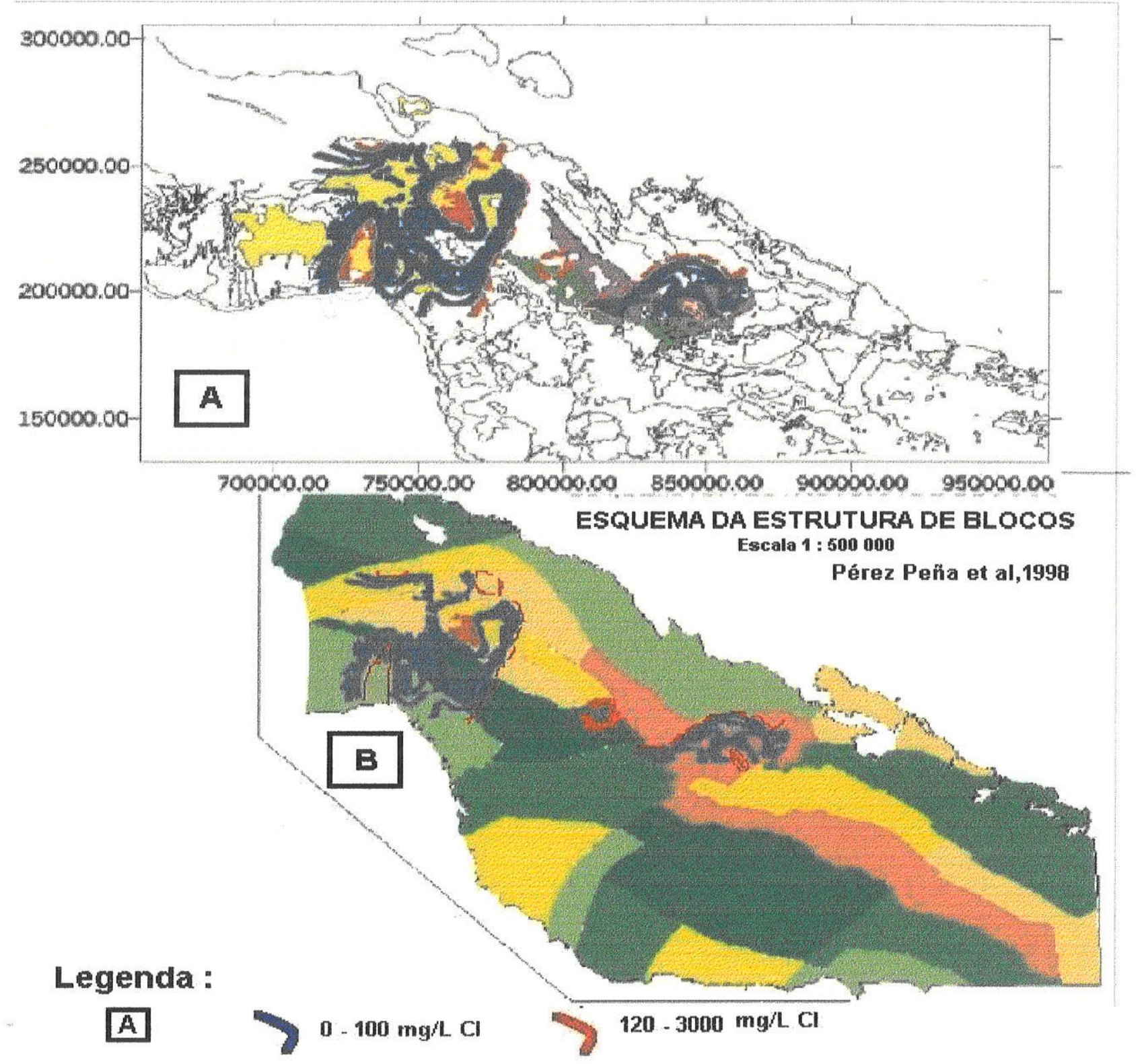

Eamplexo Ofiolítico $\square$ Formaçăo Caobillas $\square$ Formaçăo Guines

Escala $1: 1750000$

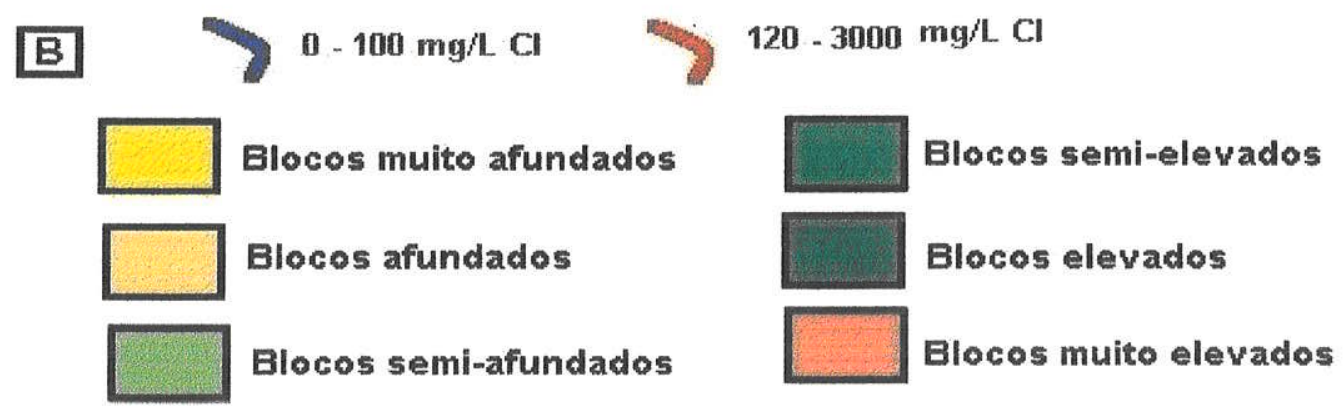

Escala $1: 500000$

Figura 75. Comparação da distribuição das concentrações dos cloretos das águas subterrâneas das formações dos ofiolitos, Caobillas e Guines no mapa geológico utilizado com o esquema tectônico de blocos estruturais da região de estudo.

(Pérez Peña et al, 1998) 
O que pode se interpretar da participação das estruturas "estáticas" existentes nas águas subterrâneas do território, destaca-se na Figura 75. Nela comparamse as distribuições de cloretos, já analisadas na sua apresentação superficial, extrapoladas ao campo dos blocos estruturais da geologia (Pérez Peña, 1998) da região de estudo.

Evidentemente, como os limites dos blocos são dependentes dos sistemas de falhas, sobre todo La Trocha e Camaguey, a análise chama a atenção sobre as alturas relativas dos blocos no território.

Aprecia-se que a existência das maiores concentrações dos cloretos, está relacionada com os limites e trocas de alturas dos respectivos blocos. Entanto as menores concentrações dos cloretos $(<100 \mathrm{mg} / \mathrm{L}$ ) abundam nos blocos mais elevados, as maiores concentrações $(120-3000 \mathrm{mg} / \mathrm{L})$, surgem quando estas entram nos blocos de menor nível. Isso, além de dar as mesmas conclusões que analisadas sob o aspecto das formações geológicas e as suas respectivas posições relativas de suas respectivas alturas sobre o nível do mar, aporta o argumento do fator causal que dinamiza o movimento de circulação das águas subterrâneas. O comportamento é o mesmo, analisado desde as alturas do relevo superficial, do que analisado pelas alturas relativas dos blocos estruturados geologicamente. Evidentemente, as particulares permeabilidades das distintas formações podem particularizar, em sentido local, tais tendências do fluxo subterrâneo. De outro ponto de vista, precisa-se detalhar que a escala da análise, em pequenas localidades, pudesse até dar, sentidos opostos, à tendência da circulação regional aqui expressa. 


\section{Modelo hidrogeoquímico de fluxo.}

Todas as interpretações antecedentes fundamentaram certas particularidades refletidas através dos seus respectivos fatores de análise. Em primeiro lugar está ponderar a distribuição do quimismo das águas subterrâneas da região de estudo, do ponto de vista do predomínio dos ânions, segundo as concentrações existentes dos cloretos, para podermos generalizar com respeito à distribuição das suas idades.

A Figura 76 apresenta um mapa geológico com o único perfil geológico regional existente da região de estudo. A perspectiva utilizada na figura é para manter a devida dependência interpretativa entre o mostrado na superfície e o estimado em profundidade. $\mathrm{O}$ fato de adotar este esquema equivale a subordinar as interpretações à configuração e conceição geológicas predominantes na literatura cubana.

Para dar a devida continuidade à análise hidrogeológica tem-se levado em consideração aspectos relacionados com os agrupamentos das formações geológicas, de acordo com a divisão dos processamentos efetuados e sob a possibilidade que, neste sentido, ofereça uma avaliação regional. Não devemos perder de vista que o plano transversal é paralelo às Falha La Trocha e Falha Camaguey que representam as direções predominantes NE-SO das estruturas, consideradas como antigas e ativas desde o Cretáceo (Carbeny, 1999).

Todas as interpretações foram feitas com base na concentração dos cloretos das águas subterrâneas como indicador universal do processo de enriquecimento das suas salinidades. A análise foi feita considerando os valores de cloretos das respectivas formações e o tipo aniônico predominante correspondente, em função dessa concentração de cloretos. A Figura 77 apresenta a interpretação gráfica resultante deste enfoque.

A aparente intrusão de águas dos tipos cloretados e sulfatados concebe a interpretação do fluxo existente de acordo com as deduções anteriores relacionadas com a influencia das estruturas regionais. As águas de máxima salinidade, procedentes das jazidas de petróleo, indicam a possibilidade de suas presenças a maiores profundidades, de águas altamente cloretadas, ainda não refletidas na superfície.

Com a interpretação da superfície do território e os resultados anteriores, chega-se ao Mapa da distribuição aniônica das águas subterrâneas da Região Centro Oriental de Cuba (Figura 78).

Os processamentos anteriores permitiram apontar que as tendências predominantes da formação paleógenica de Vertientes e da Formação cretácea de Caobillas são de conter águas sulfatadas e cloretadas respectivamente. Nesse sentido, as manifestações das referidas formações do território no mapa foram consideradas sob estas tipologias definidas, excepcionando os desvios particulares. 


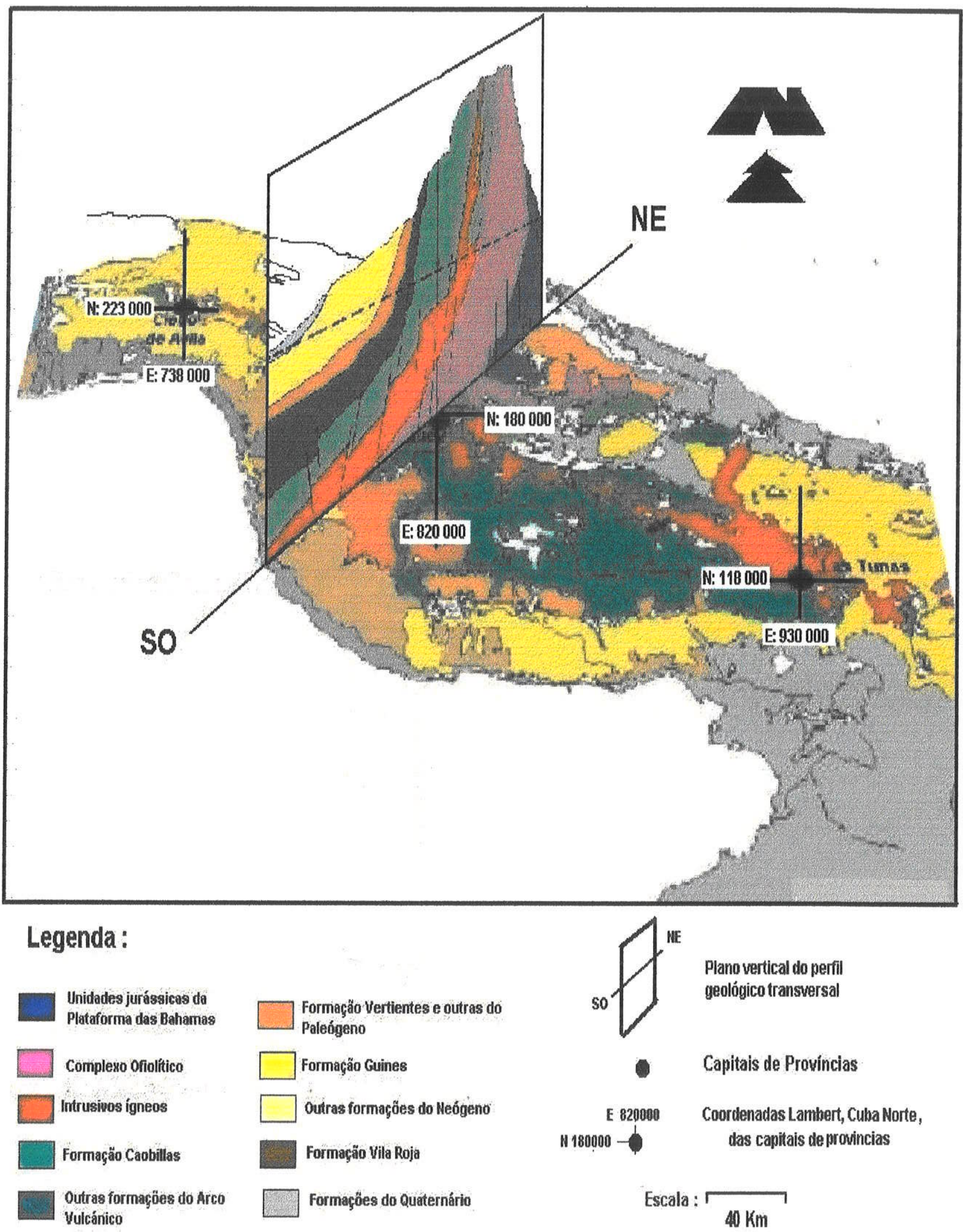

Figura 76. Montagem em perspectiva do mapa geológico $\left(10^{\circ}\right.$ na horizontal) e o seu perfil correspondente NE - SO da região de estudo, onde nota-se a concordância entre o mapeado na superfície e a continuidade em profundidade das formações geológicas.

(Fonte: Mava Geolóaico de Cuba. 1988) 


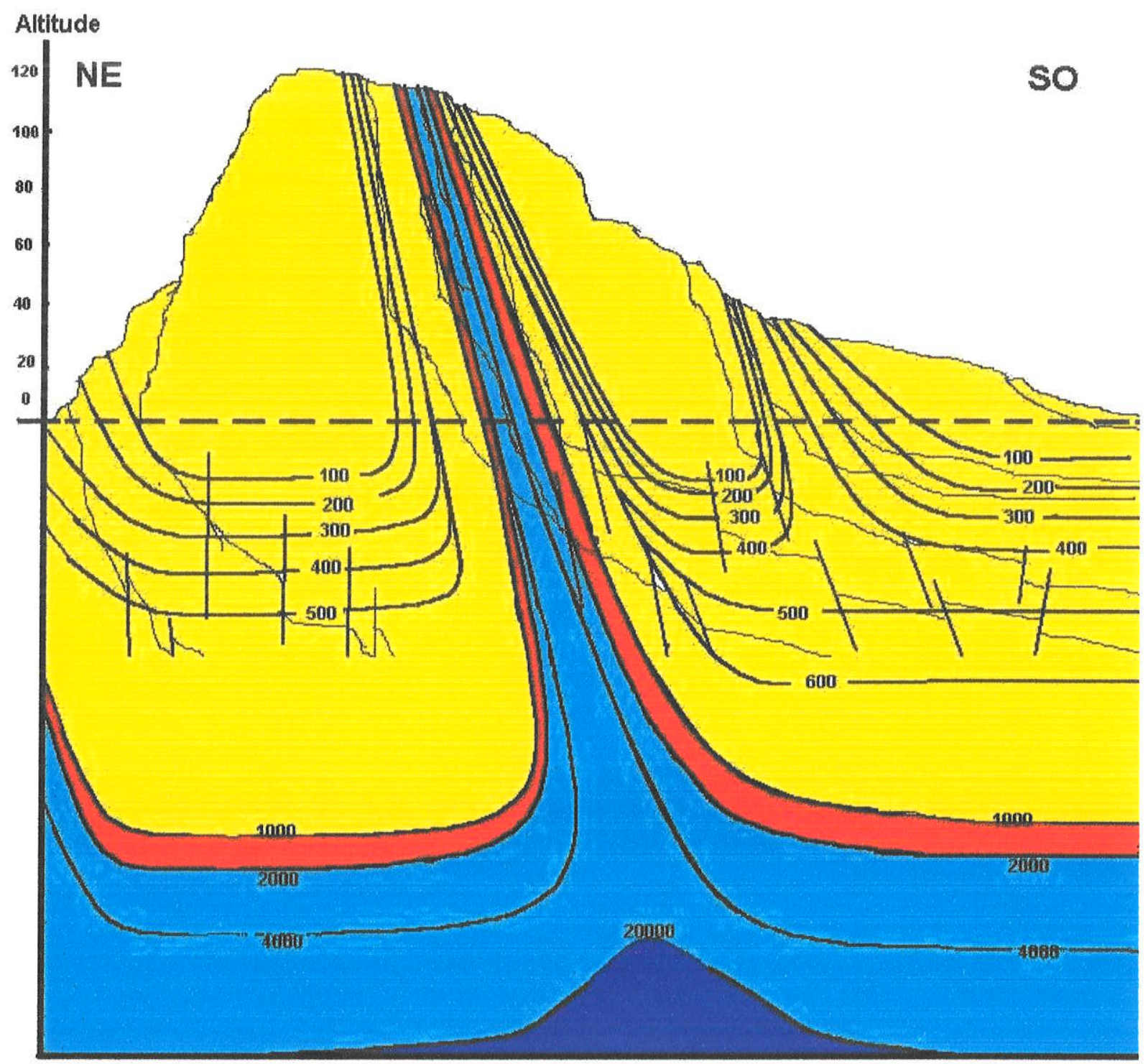

Legenda :

Tipo aniónico predominante das águas subterrâneas em função dos seus teores de cloretos:

$\square$ Bicarbonatadas ( $<100 \ldots 1000$ mgil de Cloretos)
$\square$ Sulfatadas ( 1000 -- 2000 mgil de Cloretos)
$\square$ Cloretadas ( $2000 \ldots 4000$ mgil de Cloretos)
Muito cloretadas ( $>20000$ mgil de Cloretos)

Figura 77 Esquema da interpretação no perfil NE-SO da distribuição dos tipos aniônicos das águas subterrâneas, com relação aos seus teores de cloretos.

Notas :

As escalas vertical e horizontal são referenciais e não mantêm proporção nenhuma. As profundidades dos limites dos respectivos quimismos são totalmente interpretadas a partir das suas manifestações na superfície. 
É evidente que do ponto de vista aniônico, a aparência das distribuições do tipo bicarbonatado é mais uniforme, permitindo estabelecer este tipo aniônico como o patamar representativo da maioria das águas subterrâneas da região, dentro do qual, os tipos sulfatados, de menor freqüência, e o tipo cloretado, de freqüência maior, como o indicadores anômalos de águas provenientes de maiores profundidades, ou também, como foi analisada, a possível drenagem subterrânea de retorno. Esclarece-se, mais uma vez, que para as zonas costeiras, os critérios afirmados, devem ser mais cuidadosos. Como patamar bicarbonatado pode se considerar também aquelas áreas nas quais predominam as águas em processo de recarga e circulação pouca profunda, onde existem as espessuras principais de exploração dos aqüíferos.

Quando se delimitam as mencionadas formações relacionadas com os cloretos e sulfatos, pode ver-se a mesma correspondência com as interpretações anteriores e o destaque daqueles alinhamentos estruturais que permitem as ascensões das águas mais salinizadas à superfície, pela mesma zona que aparece no seu perfil correspondente.

Analisando as águas do ponto de vista das idades, calculadas segundo a concentração dos cloretos (MCC), obtêm-se às Figura 79 e Figura 80 , que representam respectivamente, o perfil e o mapa das idades das águas subterrâneas da região de estudo.

O interesse de relacionar os valores em milhões de anos a seus respectivos equivalentes estratigráficos é para estabelecer um nível referencial comparativo. O fato de que este mapa é o primeiro que distribui as idades das águas subterrâneas numa escala regional em Cuba, não proporciona comparação com similares. Mas, como se discutiu nas argumentações do processo da Cloretogênese e o Método de Datação das águas subterrâneas pela Concentração dos Cloretos no respectivo capítulo: 1) as datações conseguidas em estudos anteriores não têm alcançado a escala regional $\mathrm{e}, 2$ ) a faixa de idades avaliada pelos outros métodos não tem ultrapassado ao milhão de anos, o que faz do mapa apresentado ser o primeiro desta natureza na especialidade. Por carecer de exemplos comparativos, existe a necessidade em exprimir a distribuição das idades das águas em referências estratigráficas em lugar de anos, por serem mais conhecidas e mais utilizadas.

A interpretação deste mapa é uma uniformidade das idades quaternárias, Pleistoceno, interrompida na faixa central por águas de idade neogênicas. Ainda que pudesse parecer monótona a distribuição geral, a avaliação é conseqüente com as argumentações antecedentes e, se verifica, mais uma vez, que a zona da Formação Caobillas representa, para os fins da circulação regional das águas subterrâneas, um plano de fraqueza que comunica a superfície territorial com os niveis de maiores salinidades, mais profundos da região de estudo, de idades mais antigas.

Pelos resultados dos processamentos, a possibilidade que nas profundidades existam águas com altas concentrações relacionadas com jazidas de petróleo é muito grande. Os casos conhecidos estão ao Oeste da região de estudo, 


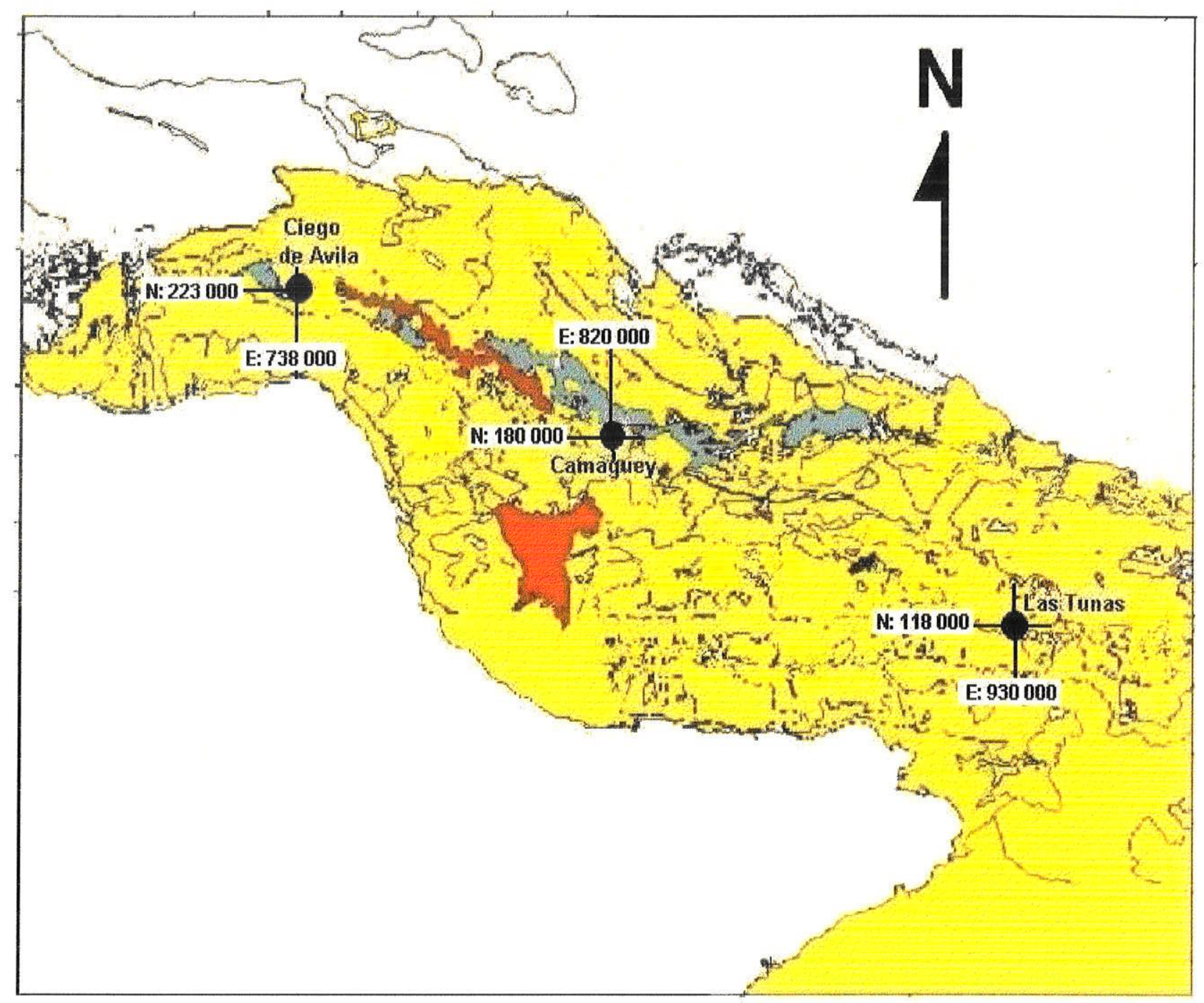

Legenda :

Tipo aniónico predominante das águas subterrâneas em funçăo dos seus teores de cloretos:

\begin{tabular}{|c|}
\hline Bicarbonatadas ( $<100--1000$ mgil de Cloretos) \\
\hline Sulfatadas ( 1000 -- 2000 mgil de Cloretos) \\
\hline Cloretadas (2000 --> $4000 \mathrm{mg} / \mathrm{L}$ de Cloretos) \\
\hline Muito cloretadas ( $>20000 \mathrm{mg} / \mathrm{L}$ de Cloretos) \\
\hline
\end{tabular}

- Capitais de provincias

Figura 78. Mapa da distribuição aniônica das águas subterrâneas de Cuba Centro Oriental.

(Fonte: Mapa Geológico de Cuba, 1988) 


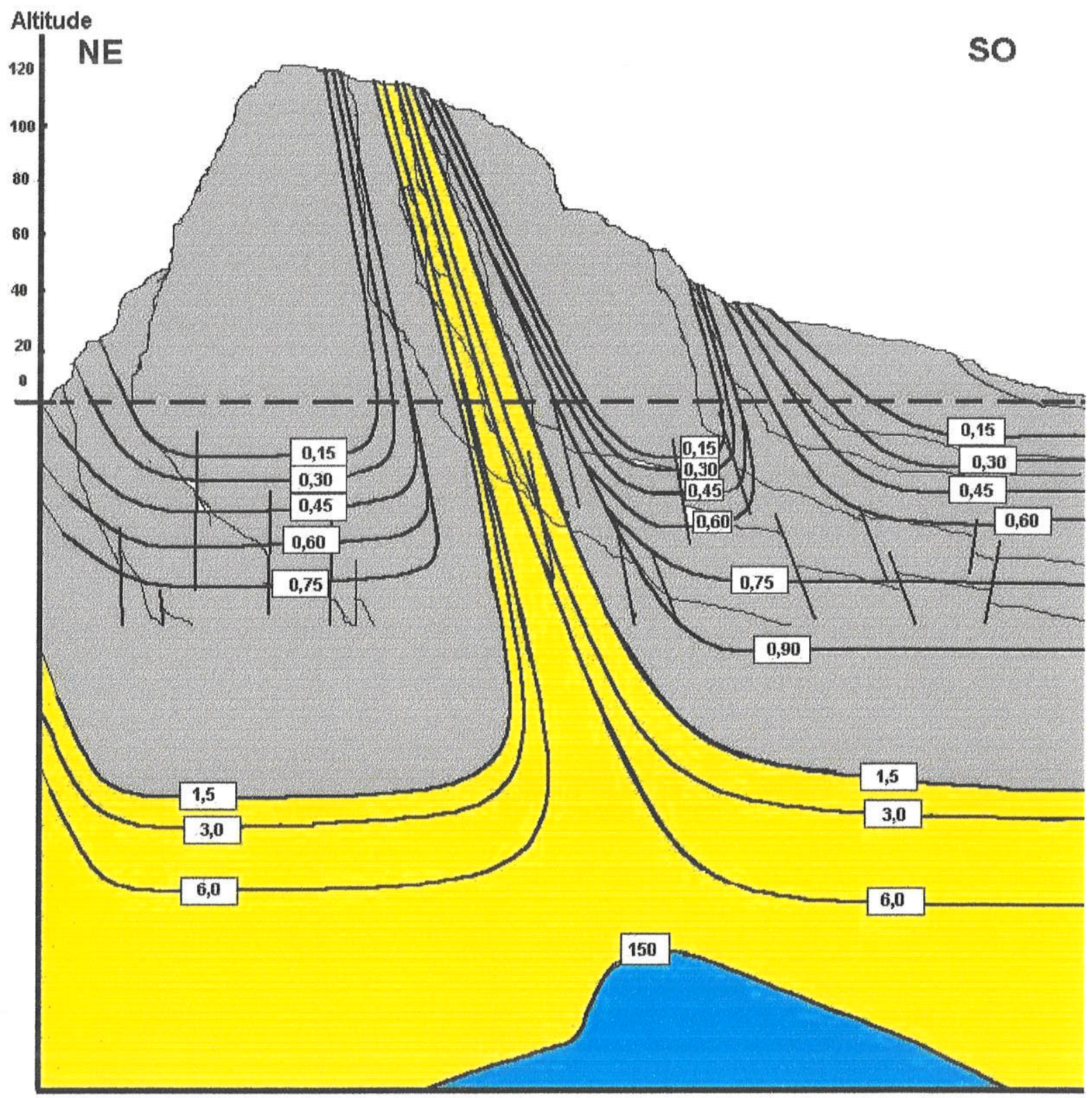

Legenda : Idades calculadas nas águas subterrâneas da região de estudo:

- 0,75 Milhöes de anos (MCC)

- Referenciadas com as idades estratigráficas

$\begin{array}{cll}\text { Cenozôica } & \text { Quaternário } & \text { Pleistoceno } \\ & \text { Terciârio } & \text { Neógeno } \\ \text { Mesozóico } & \text { Jurássico } & \text { Superior }\end{array}$

Figura 79. Perfil da distribuição das idades em milhões de anos e referenciadas com as idades estratigráficas.

Notas:

As escalas vertical e horizontal são referenciais e não mantêm proporção nenhuma. As profundidades dos limites das respectivas idades são totalmente interpretadas a partir das suas manifestações na superficie. 


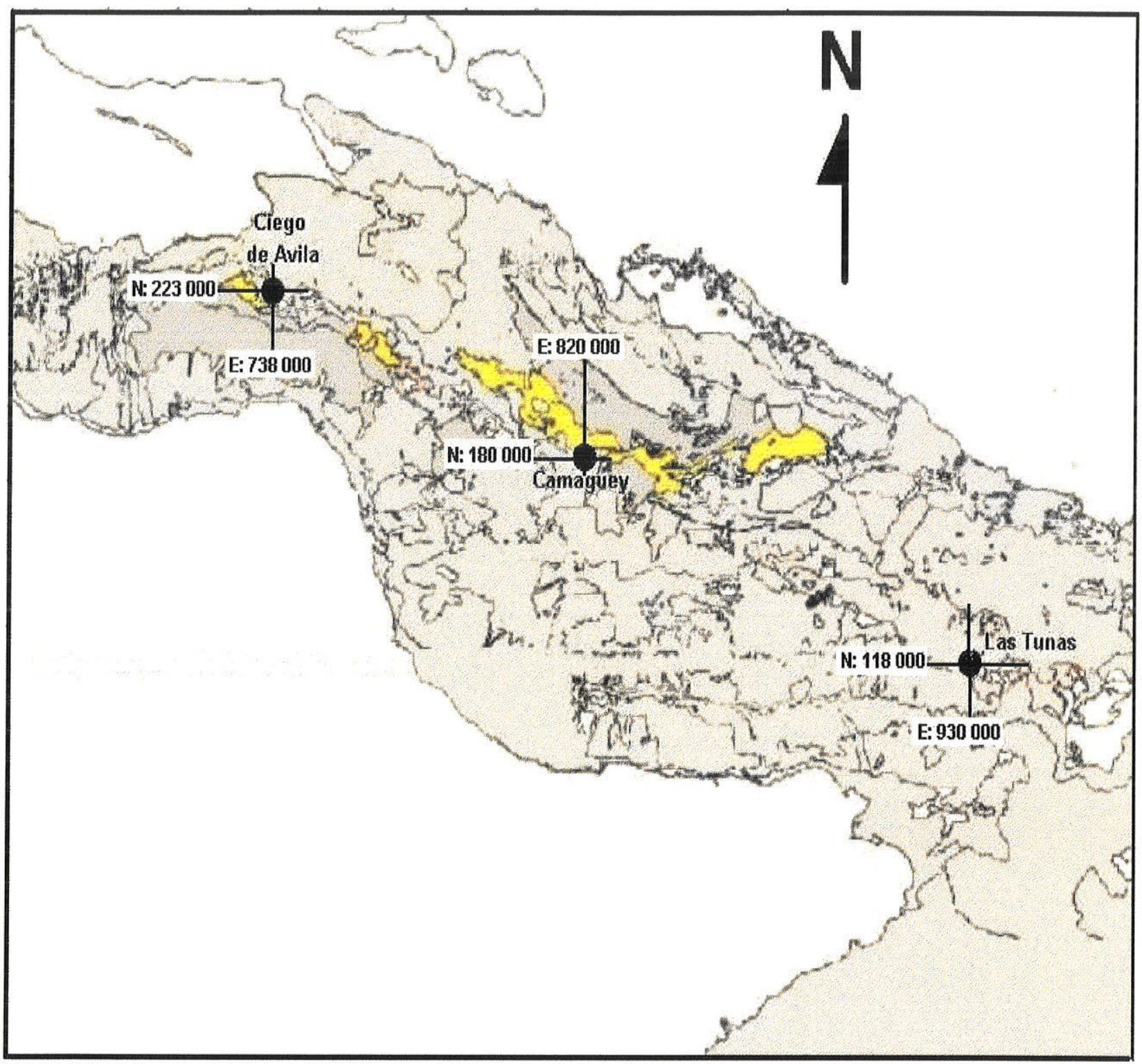

Legenda :

Idades calculadas nas águas subterrâneas da região de estudo:

(Referenciadas com as idades estratiaráficas)

$\begin{array}{cccc}\text { Cenozôica } & \text { Quaternário Pleistoceno } \\ \text { Terciârio Neógeno } & \text { Capitais de Províncias } & & \text { Escala : } \\ 40 \mathrm{Km}\end{array}$

Figura 80. Mapa da distribuição das idades das águas subterrâneas de Cuba Centro Oriental.

(Fonte: Mapa Geológico de Cuba, 1988) 
Ciego de Ávila, mas devido as águas minerais medicinais da região estarem relacionadas com as jazidas e manifestações de petróleo nela existente, e, que as mesmas tenham relação direta ou indireta com a Formação Caobillas, fazem crer que nesta formação haja perspectiva maior para a obtenção de águas de maiores salinidades ou condiciona-la como um elemento interessante à prospecção de petróleo.

As indicações já referidas de que águas minerais relacionadas com a Formação Caobillas possuem artesianismo, assim como aquelas águas relacionadas com jazidas de petróleo, fundamentam a opinião de que estes aqüiferos, quaisquer que seja sua dimensão, disposição e intercomunicação, são águas potencialmente circulantes, que permite assumir, do ponto de vista hidrogeoquímico, serem parte de um processo ainda contínuo da formação das suas composições salinas.

Relacionando o demonstrado anteriormente e fazendo uma análise dedutiva, pode ser estabelecido um modelo de fluxo a partir das considerações hidrogeoquímicas, com a participação das leis da hidráulica subterrânea dentro do meio geológico.

A Figura 81 exemplifica a interpretação geral do movimento do fluxo subterrâneo dentro da região de estudo. Aos mapas anteriores das Figuras 78 e 80 foi feita uma montagem em perspectiva $\left(10^{\circ}\right.$ na horizontal) com a finalidade de evidenciar que por qualquer uma via, as interpretações são concordantes.

No sentido geral, os mapas representam a interpretação da evolução química das águas subterrâneas sob as argumentações do processo da Cloretogênese em suas manifestações particulares na geologia da região de estudo.

Como foi comentado, destaca-se a presença de um segundo plano de circulação de águas cloretadas, de altas concentrações, acionadas pela recarga natural em altitude mais elevadas, sem as quais não se manifestariam na superfície do território, através das estruturas principais.

Não podemos esquecer de, dentro destas generalidades do modelo de fluxo das águas subterrâneas, especificar que a influencia das águas do mar deve participar notavelmente nestes fluxos mais profundos, mas devido a carência dos dados que permitiram concluir algo no que diz respeito a esto, entende-se melhor não fazer referência a esta particularidade. Deixa-se apenas anunciado como um futuro fator, que as profundidades do mar em volta de Cuba estão na ordem dos $5 \mathrm{~km}$, valor alcançado apenas pelas obras petroleiras.

Apesar de ter como referência principal um perfil central da região e a partir dele estender as considerações abordadas, deve-se tomar atenção para as possibilidades estruturais e geológicas particulares que permitem desviar a concepção geral do modelo de fluxo regional apresentado, das complicações específicas condicionadas pela análise local. 


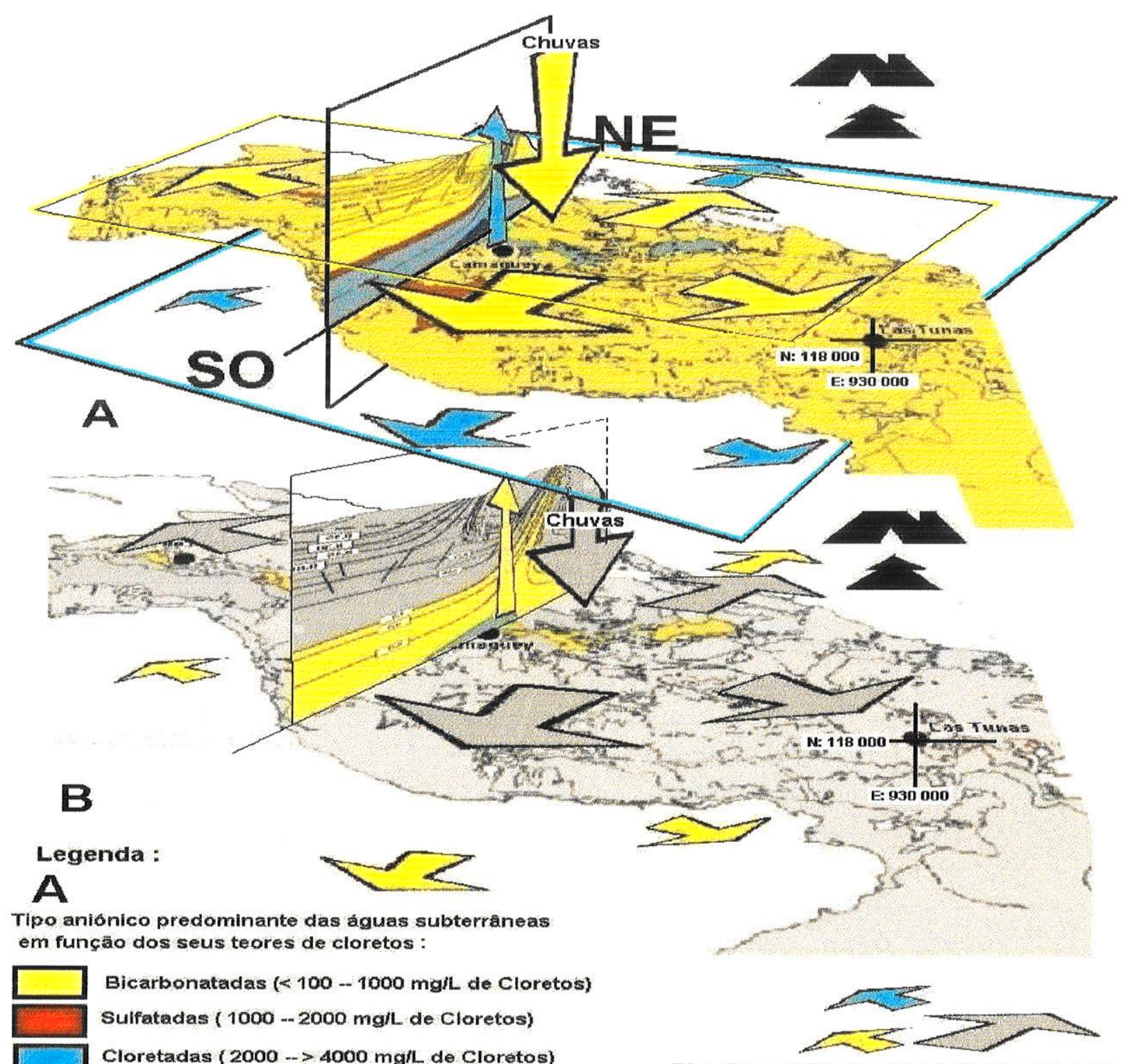

$\square$ Cloretadas ( 2000 --> 4000 mgil de Cloretos)

Direçöes predominantes do fluxo subterrâneo (As cores das setas representam o tipo de águas fluindo) Muito clorotadas ( $>20000 \mathrm{mg} h \mathrm{~L}$ de Cloretos)

Plano representativo do primeiro nivel de profundidade do fluxo subterrâneo (Águas bicarbonatadas até levemente cloretadas)

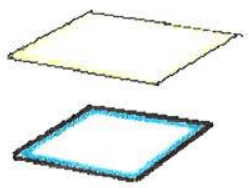

Plano representativo do segundo nivel de profundidade do fluxo subterråneo

(Aguas cloretadas até fortemente cloretadas)

B

Idades calculadas nas águas subterrâneas da região de estudo (Referenciadas com as idades estratiaráficas)

Cenozöica

Quaternário Pleistoceno
Terciário Neógeno
(O tamanho das setas condicionam o valor relativo do escoamento subterrâneo)

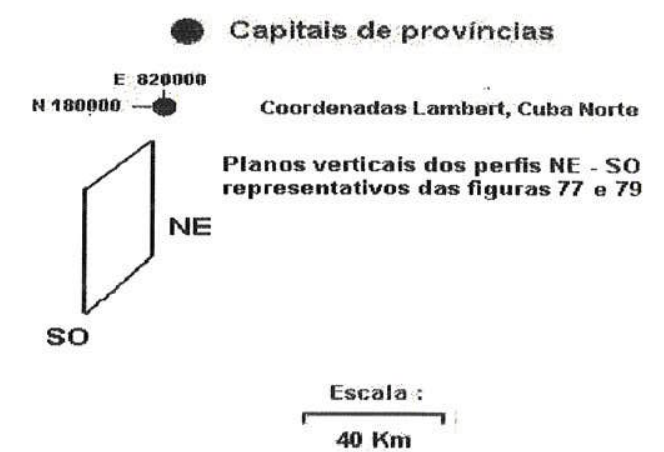

Figura 81. Representação do modelo hidrogeoquímico de fluxo subterrâneo, com relação a distribuição aniônica e distribuição das idades das águas subterrâneas da região Cuba Centro Oriental. 


\section{Conclusões e Recomendações}

As conclusões foram ordenadas na mesma ordem que concebidas.

\section{Relação rocha/água subterrânea.}

-Existe correspondência significativa entre o quimismo das rochas e as suas respectivas águas subterrâneas na região de estudo.

-Corrobora-se com esta correspondência dos resultados alcançados entre o quimismo das rochas e das águas analisadas, a representatividade e confiabilidade dos dados da informação utilizada.

-A tipologia hidrogeoquímica das águas subterrânea que circulam pelas distintas formações geológicas é similar às reportadas pela literatura especializada. Diferenciam-se aquelas reportadas destas analisadas pelo fato de que as águas da região de estudo são muito mais salinizadas, quando caracterizadas em $\mathrm{mg} / \mathrm{L}$ de STD. Destaca-se nestas particularidades os conjuntos das rochas ígneas. As rochas ígneas da região de estudo (granitos e granodioritos principalmente) alcançam os $500 \mathrm{mg} / \mathrm{L}$ de STD, enquanto as médias dos mesmos tipos rochosos não ultrapassam os $300 \mathrm{mg} / \mathrm{L}$. Estw fato parece basear-se nas diferenças das intensidades dos processos de erosão entre as zonas continentais e as insulares, que às composições particulares das formações rochosas. O clima tropical úmido e a reduzida extensão das formações geológicas na ilha, favorecem um desenvolvimento mais enérgico e permanente dos processos hidrogeoquímicos, em especial do ataque mais enérgico e profundo do $\mathrm{CO}_{2}$.

-Estas condicionalidades particulares insulares, caracterizadas por áreas reduzidas de afloramentos e profundidades dos conjuntos litológicos através dos quais formam-se e circulam as águas subterrâneas, permitem evidenciar uma coexistência dos diferentes tipos hidrogeoquímicos de águas (bicarbonatadas, sulfatados e cloretados) dentro uma mesma litologia em qualquer uma formação geológica. Por isso, o tipo hidrogeoquímico representativo das águas subterrâneas que circulam por um conjunto específico de formação geológica é o valor meio predominante dos tipos avaliados.

\section{Correlação das condutividades com as concentrações aniônicas das águas subterrâneas.}

-Existe uma correlação significativa entre a condutividade elétrica $(\mu \mathrm{S} / \mathrm{cm})$ e o ín cloreto $(\mathrm{meq} / \mathrm{L})$ para todos as águas provenientes de todas as diferentes litologias analisadas, com independência das idades de constituição dos conjuntos litológicos. A constante continuação desta correlação com o cloreto para as concentrações acima dos $1000 \mu \mathrm{S} / \mathrm{cm}$, permite caracterizar a transição do tipo bicarbonatado existente ao inicio da infiltração, reconhecido para as águas superficiais e sub superficiais, ao tipo cloretado, presente em todas as 
formações analisadas, na medida que vão concentrando-se pelos processos que acontecem durante a sua trajetória.

-O ânion cloreto é o único que mantém uma correlação significativa $(0,997)$ com os Sólidos Totais Dissolvidos (STD) e Condutividade $(\mu \mathrm{S} / \mathrm{cm})$ para qualquer concentração (Avaliada desde os valores de concentração menor dos 1000 até os maiores de $508840 \mathrm{mg} / \mathrm{L}$ de STD). Tal correlação pode ser vista graficamente mesmo em $\mathrm{mg} / \mathrm{L}$ ou $\mathrm{meq} / \mathrm{L}$.. Este comportamento não ocorre para os ânions bicarbonatos e sulfatos cujas correlações têm uma faixa mais limitada.

-Os ânions $\mathrm{HCO}_{3}$ não tem uma correlação significativa quando os valores da sua concentração excedem os $10 \mathrm{meq} / \mathrm{L}(610 \mathrm{mg} / \mathrm{L})$. Existe uma correlacionalidade significativa visível nos gráficos correspondentes até esse limite, a partir do qual, o bicarbonato mantém-se constante na solução. Este limite pode ser concebido como o cessar da influencia da ação básica que exercem as pressões parciais do $\mathrm{CO}_{2}$ na solubilidade dos carbonatos existentes nas diferentes rochas até o alcance da atmosfera subterrânea. Esta relação geral para todas as formações estudadas permitiria poder quantificar o limite de ação do $\mathrm{CO}_{2}$ desde a superfície até as profundidades das águas subterrâneas.

-A avaliação do comportamento do íon $\mathrm{SO}_{4}$ ainda não pode se generalizar como os casos anteriores. A sua concentração nas águas analisadas é baixa, sua correlação não é significativa, mais também não é rejeitável, e não apresenta limites tão nítidos e visíveis quanto aos anteriores, com os aumentos das concentrações. Tem um comportamento quase médio entre o cloreto e o bicarbonato. A sua presencia maioritária pode representar a dissolução de transição entre as águas de recém infiltração (bicarbonatadas) e aquelas que circulam até ou nas profundidades (cloretadas). A sua ausência pode representar uma condicionalidade de gêneses muito específica, possivelmente relacionada com jazidas de petróleo ou águas sulfurosas.

\section{Derivações gerais a partir das análises químicas na literatura internacional especializada sobre a evolução dos cloretos nas águas subterrâneas quando alcançam valores extremos de concentração.}

-Demonstra-se a existência de um processo hidrogeoquímico particular das águas subterrâneas que rege, após infiltradas, a tendência destas a concentrar-se em cloretos até os valores máximos possíveis. Avaliou-se o processo pela sua manifestação contínua no único sentido de concentrar-se apenas em cloretos na mesma proporcionalidade do aumento da concentração total.

-Por ser o enriquecimento em cloretos a característica destacada deste processo, chamou-se de Cloretogênese.

- O processo começa destacar-se quando que a concentração total das águas subterrâneas ultrapassa aos $1000 \mathrm{mg} / \mathrm{L}$ de STD e continua até que a 
concentração total alcance o máximo, segundo permitam as condições geológicas particulares da região analisada.

. O ânion cloreto é o indicador hidrogeoquímico universal da concentração geral das águas subterrâneas.

- Este processo de enriquecimento do cloreto nas águas subterrâneas é independente da gênese original do tipo de água inicial, pelo que resulta dificultoso determinar o tipo litológico de procedência das águas subterrâneas a partir dos $1000 \mathrm{mg} / \mathrm{L}$ de STD.

. Este processo de enriquecimento do cloreto nas águas subterrâneas começa com a infiltração das águas superficiais e termina quando a sua concentração é máxima no lugar determinado.

- A aplicação conceitual deste processo da cloretogênese, permite regularizar a análise regional da circulação das águas subterrâneas interpretando a distribuição dos valores dos cloretos no território, qualquer uma que sejam as procedências e tipos das águas existentes. Do ponto de vista relativo, os valores menores de cloretos, corresponderão com aquelas de infiltração mais recentes e os maiores, com as mais antigas.

- A aplicação conceitual do processo da Cloretogênese, quando generalizado que opera num só sentido e que é medivel na sua progressão através do enriquecimento da sua concentração, e sendo comum a todas as águas subterrâneas, independentes da condição e lugar de origem, justifica associaro com o tempo em que age, o que permite:

-Fundamentar um novo método de datação de águas subterrâneas, o Método da Concentração do Cloreto (MCC).

- Este método fundamentado (MCC) concorda favoravelmente nos seus resultados com os outros métodos existentes.

. O método permite avaliar relativamente que águas de maior concentração do cloreto são mais velhas, ou tem mais tempo de circulação, que aquelas de menor concentração, se não existe causa locais evidentes como mar, jazidas da alta concentração de sais (halita, gesso), solos salinizados, residuais humanos.

- Este método é mais barato que as técnicas isotópicas, radioativas e de microcomponentes e permite a comparação regional e inter-regional dos seus resultados. 


\section{Hidrogeoquímica da região de estudo}

A aplicação dos resultados anteriores à análise hidrogeológica regional, permite as considerações a seguir:

-Fundamentamse, do ponto de vista hidrogeoquímico, o Mapa da Distribuição dos Ânions das Águas subterrâneas de Cuba Centro Oriental. Esta conceição permite estabelecer e apreciar o tipo bicarbonatado como o patamar regional das águas subterrâneas e os tipos sulfatados e cloretados como as anomalias que indicam particularidades na superfície do fluxo subterrâneo regional.

-Fundamenta-se o Mapa da Distribuição das Idades das Águas Subterrâneas de Cuba Centro Oriental. Esta conceição permite estabelecer a ordem original das águas subterrâneas, do mesmo modo que a determinação paleontológica para descriminar a posição das formações geológicas.

-Concebe-se um Modelo de Fluxo Regional a partir das interpretações hidrogeoquímicas.

-As águas mais jovens da região de estudo e com faixa de idades similares (Pleistoceno) são as provenientes e circulam pelos Complexo Ofiolítico e formações Contramaestre, Guines e Vila Roja. As serpentinitas, ou Complexo Ofiolítico, apesar de estruturar o conjunto primário, surgido a finais do Jurássico dentro a Plataforma das Bahamas, está situado nas alturas máximas da região, - que lhe permite uma função receptora superior das precipitações existentes, que the condiciona uma baixa salinidade, representativa da sua recente constituição.

-As águas da Formação Guines, devido ocuparem uma ampla extensão nas partes mais baixas do território entre as formações cretáceas do Arco Vulcânico e a zona costeira da região e devido sua alta permeabilidade, permitem-lhe recepcionar a precipitação, e também o escoamento proveniente das formações mais elevadas pré-neogénicas. Vila Roja é uma formação do Quaternário, costeira, de permeabilidade heterogênea, estratigráficamente acima da Formação Guines, que the outorga uma função similar à anterior, mas mais limitada.

-As águas dos granitos e granodioritos de Camaguey têm em geral uma parte da mesma idade pleistocénica que as anteriores descritas, mas têm águas cuja concentração de cloretos caracteriza-lhe supor que coexistem com águas de maiores idades. Pode conceber-se que têm uma função similar de recarga, por uma parte, e outras causais que condicionam misturas com águas mais velhas na sua circulação.

-Os casos relacionados com as idades mais velhas dos granodioritos Las Tunas, Formações Caobillas e Vertientes, parecem representar uma drenagem de águas em etapas mais avançadas da evolução da circulação subterrânea. 
-As águas de maior salinidade, mais velhas, neogénicas, apresentam-se refletindo as direções dos sistemas principais das estruturas cubanas, NE-SO e NO-SE, o que permite conceber, sob todas as considerações precedentes, que estes sistemas de estruturas preferenciais colaboram com uma drenagem de retorno à superfície de parte das águas subterrâneas que se infiltram. Esta drenagem parece estar acionada pelas pressões que exercem nas profundidades das águas cloretadas, as alturas das colunas das águas superiores bicarbonatadas.

-A Formação Caobillas representa o conjunto principal que permite comunicar as águas de circulação profunda com a superfície devido a sua particular associação com os planos de cavalgamento dos ofiolitos e as estruturas NESO que condicionam os planos de maior permeabilidade para o ascenso das águas cloretadas, impulsionadas pelas águas bicarbonatadas dos níveis superiores. Os granodioritos de Las Tunas pela sua dimensão e inter-relações dentro do Arco Vulcânico, representam a continuidade oriental da função de drenagem atribuída à Formação Caobillas. A Formação Vertientes, pela sua posição de Cobertura Cenozóica acima do Arco Vulcânico, representa uma função receptora das águas provenientes através da Formação Caobillas, em conjunção com o tipo salinizado de água que ela pode originar.

-Todas as formações geológicas podem conter determinadas presencia de águas cloretadas de maior idade que as pleistocénicas, mas as mesmas estão relacionadas com sistemas menores de estruturas que permitem condicionar sistemas de recirculação em escalas mais reduzidas ou locais, representativas e em bom equilíbrio com a situação regional.

-Pode generalizar-se que os planos dos lineamentos neotectónicos ativos desde o Paleógeno, controlam a circulação das águas cloretadas mais jovens $(\mathrm{Cl}$ entre 120 e $3000 \mathrm{mg} / \mathrm{L})$ e as estruturas antigas profundas, ativas desde o Cretáceo, controlam a circulação das águas cloretadas mais velhas ( $\mathrm{Cl}$ maior de $10000 \mathrm{mg} / \mathrm{L}$ ).

-Evidencia-se para a escala regional de um território de alta complexidade geológica, como o analisado, que as grandes estruturas e o seu estado de atividade regem a grande circulação e evolução das águas subterrânea.

-Evidencia-se que as águas minerais são particularidades casuísticas dentro do regime geral das águas subterrâneas do território e cuja constância natural das suas propriedades específicas estão equilibradas sob as mesmas leis do sistema geral das restantes águas subterrâneas.

-Do ponto de vista das idades, as águas minerais mais velhas da região de estudo relacionam-se com o Neógeno (Veracruz, El Azufre e Camujiro) e as demais, as mais jovens, ao Pleistoceno (Tamarindo, Peña Azul, Paso de Lesca e Chaparra). 
-As águas minerais mais velhas de Cuba relacionam-se com o Paleôgeno e pertencem às jazidas de Elguea e Menendez na província de Matanzas, ao oeste da região de estudo.

-As águas cloretadas profundas altamente salinizadas, relacionadas com as jazidas de petróleo na região de estudo têm as suas idades entre o Paleógeno (Jatibonico 69) e Jurássico Inferior (Agustín 8) sendo representativas do sistema de circulação mais antigo e cuja gênese parece estar associada aos inícios da história geológica deCuba.

\section{Recomendações}

\subsection{Para a prospecção das águas minerais}

-As águas bicarbonatadas de qualquer concentração estão diretamente relacionadas com as condições superficiais de infiltração.

-As águas cloretadas indicam o relacionamento direto com as condições nas profundidades, mais profundas quanto mais salinizadas, se comparadas com as suas concentrações entre si.

-As águas sulfatadas indicam as circunstâncias intermediarias entre estes tipos anteriores e por isso, as da composição química mais instável. Podem ser excetuados destas condicionantes gerais, os casos das águas sulfatadas relacionadas com jazidas polimetálicas.

-As potencialidades mais favoráveis para a pesquisa das águas minerais cloretadas sódicas da maior concentração no território estão na Formação Caobillas e nos granodioritos de Las Tunas. Recomenda-se que as redes de prospecção mais favoráveis, geofísica ou perfuração, deverão ser orientados para as direções perpendiculares dos sistemas NO-SE ou NE-SO das Falha Axial ou La Trocha.

-As potencialidades mais favoráveis para a pesquisa das águas minerais bicarbonatadas cálcicas estão nas formações da Cobertura Cenozóica, principalmente a Formação Guines, do Mioceno. Enquanto menos salinizadas (menor dos $300 \mathrm{mg} / \mathrm{L}$ de STD), mais superficial será a sua procedência e mais difícil manter a sua estabilidade química e a sua proteção contra a contaminação superficial. Esta dificuldade pode se incrementar nas áreas costeiras ocupadas por estas formações carbonatadas.

-As potencialidades mais favoráveis para a pesquisa das águas minerais bicarbonatadas magnésicas estão nas formações serpentiníticas e peridotíticas do Complexo Ofiolítico da região Camagueyana. A exploração destas águas deve atender as considerações previas argumentadas sobre as particularidades de infiltração nestas áreas ofiolíticas.

-As potencialidades favoráveis para a pesquisa dos outros tipos possíveis das águas minerais, principalmente, entre bicarbonatadas cálcicas e cloretadas 
sódicas, podem ser encontradas em qualquer parte do território ocupado pelas formações do Arco Vulcânico do Cretáceo, ígneas ou vulcânicas. A estabilidade química do tipo sob estudo deve ser maior na mesma medida que a sua captação fique longe possivel da influencia hidráulica das áreas baixas da Cobertura Cenozóica.

\subsection{Para a avaliação da exploração das águas minerais}

- Toda composição específica de água obtida para conveniência do seu uso mineral, deve ser avaliada especialmente enquanto a sua estabilidade da composição química para a exploração projetada. Demonstrou-se que a variação da composição química das águas, mesmo bicarbonatadas, sulfatadas ou cloretadas, dependem do estado de equilíbrio dos processos existentes no ponto, profundidade e periferias imediatas da captação das águas sob estudo. Aconselha-se executar testes de bombeamento de prolongada duração (15 dias mínimos) para evidenciar a estabilidade dos componentes hidrogeoquímicos à vazão de exploração.

-A evidenciada condicionalidade de proveniência superficial direta que significa o tipo de águas bicarbonatadas no território, justificam maiores investimentos para os estudos sobre as potencialidades de contaminação destas águas a explorar. No entanto, as águas cloretadas exigem guardar maior precaução com as potencialidades de contaminação nos seus caminhos à superfície e, as possibilidades de estabelecer comunicação destas águas com as condições de superfície, através das obras de captação ou regime de exploração.

-O fato de ser evidenciado que os tipos sulfatados das águas resultam o tipo intermediario da faixa mais estreita de salinidade total $(1000-2000 \mathrm{mg} / \mathrm{L}$ de STD) entre o superficial bicarbonatado e o mais profundo cloretado, exige uma avaliação mais rigorosa da sua estabilidade química.

-O tipo cloretado, se isolado ou longe das águas marinhas costeiras, pode resultar o de menor potencial de contaminação superficial, mas não isento de atenções quanto à profundidade de proteção do poço e da avaliação da sua estabilidade química de exploração.

-Pelo seu bom efeito sobre a saúde humana que fazem as águas cloretadas, e tendo sido evidenciada a potencialidade da existência delas nas profundidades no território interior não costeiro, seria conveniente que a Hidrologia Médica analisasse os benefícios particulares das diferentes concentrações dos cloretos para as distintas faixas (menores e maiores que as do mar) accessiveis de localizar em fontes na região. 


\section{REFERÊNCIAS BIBLIOGRÁFICAS}

AFSIN, M. (1997) Hydrochemical evolution and water quality along the groundwater flow path in the Sandiki plain, Afyon, Turkey. Environmental Geology, v. 31, n. 3/4, p. 122-143.

ALLEN, H.E.; PERDUE, E.M.; BROWN, D.S. (1993) Metals in groundwaters. New York, Lewis Publishers. 437 p.

ALVAREZ, N.; MORENO, A. M. (1996) Las aguas minerales y mineromedicinales en Cuba. In: FAGUNDO, J.R.; PEREZ FRANCO, D.; GARCIA, J.M.; ALVAREZ, A .; MORELL, I. Contribuciones a la hidrogeología y medio ambiente en Cuba. Valencia REPROVAL, S.L.. p . 301-310.

ANDREWS, J.E.; BRIMBLECOMBE, P.; JICKELLS, T.D.; LISS, P. (1996) An intoduction to environmental chemistry. Oxford, Blackwell Science, Ltd. Editorial Offices. $209 \mathrm{p}$.

APELLO, C.A ; POSTMA, D. (1993) Geochemistry, groundwater and pollution. Rotterdam, Balkema. 280 p.

ARANYOSSY, J.F. ( 1989 ) Quelques exemples pratiques d'aplication des isotopes de l'environement aux études hydrogéologiques. Hydrogeolgie, n. 3, p. 159-166.

ARMIJO, M. (1992) Aguas Minerales y Mineromedicinales: Mecanismos básicos de acción. In: INSTITUTO GEOMINERO DE ESPAÑA Jornadas de Aguas Minerales y Mineromedicinales en España. Madrid, ITGME. p. 8,3-8,17.

ARMIJO, M.; SAN MARTIN, J. (1984) La Salud por las Aguas Minerales. Madrid, EDAF, S.A. 120 p.

ATWIA, M.G.; HASSEN, A A ; IBRAHIM, Sh. (1997) Hydrogeology, Log Analisis and Hydrochemistry of unconsolidated aquifers south of El-Sadat City, Egypt. Hydrogeology Journal. V. 5, n. 2, p 128-142.

AWAD, A R.; TAGIELDIN, S.A ; AL-HOMOVED, A S.; BARAKET, E. A (1997) Hydrochemical assesssment of a deep Jordanian Aquifer. Environmental Geology, v. 31, n. 3/4, p. 18-31.

BARBAGALLO, J.; VIZCAINO, A ; GONZALEZ, A R.; CAMPOS, F. (1994) Hidrogeoquímica de Acuíferos Costeros, San Clemente del Tuyu, provincia de Buenos Aires, Rep. De Argentina. Anais Congresso Brasileiro de Águas Subterrâneas. p 1-10.

BARBECOT, F., MARLIN,C., GIBERT, E. and DEVER, L. (2000) Hydrochemical and isotopic characterization of Bathonian and Bajocian coastal aquifer of the Caen Area (northern of Franca). Appied Geochemistry. Pergamon Press, Elsevier Science, Ltd, Oxford. Vol. 15, No. 6P p 791-806. 
BARROS MOURIÑO, O . (1997) Variabilidad de la intrusión salina en cuencas costeras cársicas de Cuba. Voluntad Hidráulica. No. 87-88, Año XXXV. pp 1120.

BARTH, S.R. (2000) Geochemical and boron, oxygen and hidrogen isotopic constraint on the origin of salinity in groundwater from the crystalline basemente of the Alpine Foreland. ). Appied Geochemistry. Pergamon Press, Elsevier Science, Ltd, Oxford. Vol. 15, No. 7.p 937-952.

BEDIENT, P.B.; RIFAI, H.S.; NEWELL, C.J. (1994) Groundwater Contamination, Transport and Remediation. New Jersey Prentice Hall, Inc. $p$ 153.

BENTLEY, H, W ; PHILLIPS, F. M. ; DAVIS, S. N. ; HABERMEHL, M. A ; AIREY, P. L. ; CALF, G. E. ; ELMORE, D. ; GOVE, H. E. ; TORGERSEN, T. (1985) Chlorine 36 dating of very old groundwater. 1. The Great Artesian Basin, Australia. Water Resources Research. Vol. 22, No. 13, December. pp 1991-2001.

BERARD, P. ( 1990 ) Alimentation en eau de la mine dór d'Hassai ( Soudan ): Impact de l'étude de télédétection. Hydrogeologie, v. 2, p. 101-111.

BISON, P.L. ( 1989 ) Contributions des isotopes de l'environement á l'étude de la recharge naturelle des aquíferes fissurés du boudier soudanien au Burkine-Faso. Hydrogeologie, n.3, p 201-214.

BLAT, R.M.; KIMMELMANN E SILVA, A . A ; PACHECO, A .(1994) Estudo Físico-Químico e Químico das águas Subterrâneas do Cemetério Vila Formosa, SP. Anais Congresso Brasileiro de Águas Subterrâneas, Recife, p. 160-168.

BOLISHEN, B.; BOGEN, J.; DEMETRIADES, A ; DE VOS, D. (1996) Regional geochemical mapping of Western Europe towards the year 2000. Journal of Geochemical Exploration, v.56, p. 5-12.

BOLVIKING, B.; KULLERID, G. (1990) Geochemical and metallogenic province. Journal of Geochemical Exploration. v. 39, 114-123.

BONILICHT, O.; TARVAINEN, T. (1996) Multi-purpose geochemical mapping produced by interpretation of geochemical exploration data sets in the Paraná, Brazil. Journal of Geochemical Exploration, v. 56, n. 3. p. 167-182.

BOMTEMPO, M. (1994) Medicina Natural. São Paulo,Editora Nova Cultura. $583 \mathrm{p}$.

BRODERMANN, J. (1948) Clasificación de las aguas minero-medicinales analizadas por el Instituto Nacional de Hidrología y Climatología Médicas. Archivos del Instituto Nacional de Hidrología y Climatología Médicas.La Habana, n. 2, p. 185-188. 
BROOKINS, D. G. (1988) Eh-pH Diagrams for Geochemistry. Berlín. 177 p.

BUCKAU, G., ARTINGER, R., GEYER, S., WOLF, M., FRITZ, P. and KIM, J.I. $(2000){ }^{14} \mathrm{C}$ dating of Gorleben groundwater. ). Appied Geochemistry. Pergamon Press, Elsevier Science, Ltd, Oxford. Vol. 15, No. 5 . p 583-598.

CAMPANE VIDAL, A.; CHENG HUANG K. (1997) Utilização da analise de agrupamento na caracterização hidroquímica. In: VII SIMPÓSIO DA QUANTIFICAÇÃO EM GEOCIÊNCIAS . Boletim de Resumos Expandidos. IGCE/UNESP, Rio Claro, Brasil, p. 23-23.

CAMPOS, H.C. (1995) Contribuição ao Estudo Hidrogeoquímico do Grupo Bauru no Estado de São Paulo. Aguas Subterrâneas, ABAS. Resumo, n .14, p. 106-108.

CAMPOS, H.C. (1995) Caracterização e cartografia das provincias hidrogeoquímicas do Estado de São Paulo. . Águas Subterrâneas, ABAS. Resumo, n.14, p. 108-109.

CAPOTE, C. 1999. Análise do controle estrutural metalogênico em Cuba Centro-Oriental, com base em dados integrados. Tese de doutoramento, Instituto de Geociências, Universidade de São Paulo; 222 p..

CAPOTE MARRERO, C. (1997) Mapa estruturo-tectónico de las principales ocurrencias metálicas. São Paulo. Resultados preliminares da pesquisa para a tese de doutorado a ser entregue em 1999

CASCARET, A ;; GARCÍA, M. (1991) Prospección Detallada y Exploración Orientativa de aguas minero-medicinales "Camujiro". Informe de producción. Empresa Geólogo-Minera de Camaguey, Unión Geólogo Minera, MINBAS, Cuba. $267 \mathrm{p}$.

CASTANY, G. ( 1967 ) Traité Pratique des Eaux Souterraines. 2.ed. París, Dunod. $452 \mathrm{p}$.

CASTANY, G. ( 1968 ) Prospection et exploitation des eaux souterraines. 2.ed. París, Dunod. $585 \mathrm{p}$.

CASTRO, M.C., STUTE, M, and SCHLOSSER, P. (2000) Comparison of ${ }^{4} \mathrm{He} y$ ${ }^{14} \mathrm{C}$ ages in simple aquifer systems: implications for groundwater flow and chronologies. Appied Geochemistry. Pergamon Press, Elsevier Science, Ltd, Oxford. Vol. 15, No.8. p 1137-1168.

CAVALHEIRO, H.; NAVAJAS SAMPAIO, C. (1994) Anomalias Hidrogeoquímicas e Contexto Estrutural da Bacia de Taubaté. SP. Anais In: CONGRESSO BRASILEIRO DE ÁGUAS SUBTERRÂNEAS, Recife. Anais. Recife, Edição ABAS/DNPM, p. 420-424. 
CELLLIGOI, A . e DUARTE, U. (1994) Aspetos Hidrogeoquímicos da Formação Serra Geral em Londina, PR. Anais In: CONGRESSO BRASILEIRO DE ÁGUAS SUBTERRÂNEAS, Recife. Anais. Recife, Edição ABAS/DNPM, p. 425-433.

CHEBOTAREV, I.I. (1955) Metamorfhism of natural waters in the crust of weathering (Part 1) Geochimica et Cosmochimica Acta Vol. 8, pp. 22-48. Pergamon Press Ltd., London.

CHEBOTAREV, I.I. (1955) Metamorfhism of natural waters in the crust of weathering (Part 2) Geochimica et Cosmochimica Acta Vol. 8, pp. 137-170. Pergamon Press Ltd., London.

CHEBOTAREV, I.I. (1955) Metamorfhism of natural waters in the crust of weathering (Part 3) Geochimica et Cosmochimica Acta Vol. 8, pp. 198-212. Pergamon Press Ltd., London.

CHEVALIER-LENIRE, G. ( 1989 ) Étude des varations naturelles du débit des sources thermales á Luchon ( Haute-Garonne, Francia) par modele hydrogeologique global pluies-débits. França. Hydrogeologie, n.3, p. 159-166.

COLLIN, J.J. (1991) Renouveau de la cartografie hidrogeologique. Hydrogéologie, n.1, p. 3-6.

COMITÉ ESTATAL DE NORMALIZACIÓN (1995) Norma Cubana de Aguas Minerales. Requisitos para la clasificación, evaluación, explotación y utilización. N.C. 93-01-218. La Habana.

CUSTODIO, E.; LLAMAS, R. ( 1976 ) Hidrología Subterránea. 2.ed. España, Ediciones Omega. $1157 \mathrm{p}$.

DARNLEY, A G.; BJORKLUND, A .; BOLVIKEN, B.; GUSTAVSSON, N. (1995) A global geochemical database for environmental and resources management. Paris. Final report of IGCP Project 259,UNESCO. $78 \mathrm{p}$.

DAVIS C. J. (1986) Statistics and data analysis in Geology. John Wileys \& Sons, Inc. New York. $2^{\text {th }}$ edition. 646 p.

DAVIS, S.N.; DEWIEST, R.J. ( 1966 ) Hydrogeology. New York, John Wiley \& Sons, Inc. 396 p.

DAZY, J.; DROGUE, C.; CHARMANDI, PH.; DARLET, CH. (1997) The influence of marine inflows on the chemical composition of groundwater in small island: the example of the Cyclodes(Greece). Environmental Geology, v. 31., n. $3 / 4$, p. 111-118.

DEERING, M.F.; EILEEN, T.M. ; SYPMIEWSKI, B.F.; CARLAM, E. (1983) Regional patterns in groundwater of Northwestern Ohio and their relation to Mississippi Valley-Type mineral ocurrences. Journal of Geochemical Exploration, n. 19, p. 158-167. 
DIAZ, A..; SOSA, C.; PASCUAL, O (1996) Utilización de criterios hidrogeoquímicos e hidrogeológicos en los trabajos de exploración y desarrollo gasopetrolíferos cubanos. In: FAGUNDO, J.R.; PEREZ FRANCO, D.; GARCIA, J.M.; ALVAREZ, A ;; MORELL, I. Contribuciones a la hidrogeología y medio ambiente en Cuba. Valencia REPROVAL, S.L.. p. 199-218.

Díaz, L.: Díaz A. 1999 Informe proyecto 2121 Recuperación Mejorada de Petróleo del yacimiento Pina. Archivo CEINPET, Cuba. 52 p.

DIAZ DE VILLALVILLA, L..; PÉREZ M.; MILIÁ , I.; DOMÍNGUEZ, E. (1995) Consideraciones geoquímicas de los arcos volcánicos de Cuba. La Habana. Documento interno, I.G., MIB. 12 p.

DINIZ, J. A . (1996) O aquífero fissural na região oeste de Pernambuco. Aspetos hudraúlicos e Hidroquímicos. São Paulo. Resumo Águas Subterrâneas, ABAS, n. 15,p. 114-116.

DIRECTORIO TURÍSTICO DE CUBA (1997) Guía de Carreteras. México, Editorial LIMUSA S. A de C.V. Grupo Noriega Editores. $34 \mathrm{p}$

DOJLIDO, J.; GERALD, A (1993) Chemistry of water pollution. Canada,John Wiley \& Sons, Inc. 758 p.

DRAY, M. (1989) Étude isotopique de l'aquifere crétace du bassin cotier béninois. Hydrogeologie, n. E, p. 167-177.

DREVER, J.I. (1988) The geochemistry of natural waters. (2 ed.). Prentice Halls, Englewood Cliffs, New Jersey. 434 p.

DUNM, C.E. (1990) Application of geochemical mapping. Journal of Geochemical Exploration, v. 39, p. 191-204.

DUVENPORT, P.H. (1993) Special volumen in geochemical mapping. Journal of Geochemical Exploration, v.49, p. 247-258.

EDMUNDS, W.M., SMEDLEY, P.L. (2000) Residence time in groundwater: The East Midlands Triassic sandstone aquifer. Appied Geochemistry. Pergamon Press, Elsevier Science, Ltd, Oxford. Vol. 15, No. 6P. p 737-752.

EDWARDS, L.M. (1982) Handbook of Geothermal Energy.Gulf Houston, Publishing Company. Book Division. 402 p.

ERDÉLYI, M.; GÁLFI, J. (1988) Surface and Subsurface mapping in Hydrogeology. Hungary. John Wiley \& Sons. 438 p.

ENGLEWOOD, C.; BENNETH, F.C.; WAGNER, G.H. (1983) Hydrogeochemical exploration for barite, Ouachita Mountain, USA. Journal of Geochemical Exploration, v.19, p 221-234. 
FAGUNDO, J. R. (1996) Procesos geoquímicos y calidad de las aguas. In: FAGUNDO, J.R.; PEREZ FRANCO, D.; GARCIA, J.M.; ALVAREZ, A .; MORELL, I. Contribuciones a la hidrogeología y medio ambiente en Cuba. Valencia REPROVAL, S.L. p. 177-198.

FAGUNDO, J. R.; VALDÉS, J.; RODRIGUEZ,J. (1996) Hidroquímica del Karst. Granada, España, Ediciones. $212 \mathrm{p}$

FAGUNDO, J. R. (1990) Evolución química y relaciones empíricas en aguas naturales. Estudio mediante simulación química del efecto de la litología. La Habana. Voluntad Hidráulica, n.82, p. 28-37.

FISHER, R.S.; MULLICEN, W.F. (1997) Hydrogeochemical evolution of Sodiom-Sulfate and Sodium-Chloride groundwater beneath the Northern Chihahuan Desert, Trans-Pecos, Texas, USA. Hannover Hydrogeology Journal, v. 5, n. 2. p. 223-237.

FONTES, J-CH. ( 1989 ) Isotopes et reserves en eaux. Hydrogeologie, n.3, p. 201-214.

FOOS, A (1997) Geochemical modelling of coal mine drainage, Summit County, Ohio. Environmental Geology, v. 31, n. 3/4, p. 32-42.

FOUILLAC, C. ( 1989 ) Étude isotopique du soufre des sulfures etudes des sulfures suls dans l'aquifere géothermal du Dogger, Bassin parisien, Hydrogeologie, n.3, p. 219-227.

FOUILLAC, C.; FOUILLAC, A.M. ( 1989 ) Étude chimique e isotropique de sources mineráles de l'Ardeche. Hydrogeologie, n. 3, p. 229-236.

FURRASOLA, G.; JUDOLEY, K..; MIJAILÓVSKAYA, M.; MIROLIÚBOV, Y.; NOVOJATSKY, I.; NUÑEZ JIMÉNEZ, A .; SOLSONA, J.B. ( 1964 ) Geología de Cuba. La Habana. Editorial Nacional de Cuba. 138 p.

FURRAZOLA BERMÚDEZ, G.; NÚÑEZ CAMBRA, K. (1997) Estudios sobre Geología de Cuba. La Habana.Centro Nacional de Informaciones Geológicas, IGP. $527 \mathrm{p}$.

GARCÍA FERNÁNDEZ, J.(1964) Estadística Elemental. Universidad de Oriente. Cuba. 194 p.

GARRELS, M.; CHRIST, C.L. ( 1965 ) Solutions, Minerals and Equilibres. London. $178 \mathrm{p}$.

GASCOYNE, M. (1997) Evolution of Redox conditions and groundwater composition in recharge-discharge environment of Canada Shield. Hydrogeology Journal, v. 5, n. 3, p. 4-18.

GHERARDI,F., PANICHI, C., CALIRO, S., MAGRO, G. and PENNISI, M. (2000) Water and gas geochemistry of the Euganean and Berician thermal district 
(Italy) ). Appied Geochemistry. Pergamon Press, Elsevier Science, Ltd, Oxford. Vol. 15, No.4 p 455-474.

GONZÁLEZ BAEZ, A . (1988) Estudio mediante isótopos ambientales y datos hidroquímicos de los cambios cualitativos y el origen de las aguas subterráneas de la parte central de la cuenca sur de Matanzas. La Habana. Voluntad Hidráulica, v. 80, p. 57-66.

GONZÁLEZ, A . ( 1983 ) Errores y Mediciones. La Habana. Editorial CientíficoTécnica. Ministerio de Cultura. $108 \mathrm{p}$.

GRASBY, S.E., HUTCHEON, I. and KROUSE, R. (2000) The influence of water-rock interaction on the chemistry of thermal springs in western Canada. Appied Geochemistry. Pergamon Press, Elsevier Science, Ltd, Oxford. Vol. 15, No.4 p 439-454.

GUTIERREZ, J.; TRAVIESO, H. ( 1978 ) Características físicas y químicas de las aguas de precipitación cubanas. Voluntad Hidráulica , n.47/48, p. 18-22.

GUZMÁN,R.; JOVA, G. (1982) Hidrogeología. La Habana. Editorial Pueblo y Educación, p.166-191.

HAMZA, V.M.; ESTON, S.M. (1981) Assessment of geothermal resource of Brazil. São Paulo, Instituto de Astronomía e Geofísica, USP. 400 p.

HENDRY, M.J.; SCHWARTZ, F.W. (1988) An alternative view on the origen of chemical and isotopic patterns in groundwater from The Milk River Aquifer, Canada. Washington. Water Resources Research, n. 10, v. 24, p. 1747-1763.

HOGH JENSEN, K. (1987) The Value of Groundwater Models for Planners and Decision-Makers. París Technical Documents in Hydrology. Unesco. 72 p.

HOLLAND, H.D. (1985) The chemistry of the atmosphere and oceans. New York. John Wiley \& Sons. 350 p.

HULL, G.E.M. (1993) Capabilities of production oriented laboratories in water sampling using ICP-ES and ICP-MS. Amsterdam. Journal of Geochemical Exploration , v. 49 , p. $358-375$.

ITURRALDE VINENT, M. (1994) Ofiolitas y arcos volcánicos de Cuba. C. Habana. IUGS, Project 364, UNESCO. Museo Nacional de Historia Natural. $254 p$

JANÉ MARTÍN, P. (1998) Directorio Turístico de Cuba. La Habana.Grupo Noriega Editores. Editorial Limusa. $318 \mathrm{p}$.

JENSEN HOGH, K. (1987) The value of groundwater models for planners and decision-makers. Paris. Project 2.46 IHP III. UNESCO. $58 \mathrm{p}$. 
JOURNEL, A . G. (1989) Fundamentals of Statistics. In: Five Lessons.Short Course of 28 th International Geological Congress. Washington, D.C.

JRUPALO, A, BUCREEV, V.V. (1965) Química.Libro de datos. La Habana Editorial Pueblo y Educación.. 112 p.

KERR, A (1990) Applications of geochemical mapping. Amsterdam. Journal of Geochemical Exploration, v.39, p. 321-330.

KIMMELMANN, A.A. ( 1990 ) Considerçòes sobre as anomalías de fluoreto no sistema aquifero Botucatu- Pirambóia, na Basin de Paraná. Atividades 19891990, Inst. de Geociencias, CEPAS, USP. Sào Paulo. p. 153-157.

KIMMELMANN, A.A. (1987) Isotopic Study of the Botucatu Aquifer System in the Brazilian Portion of the Paraná Basin. São Paulo, Atividades 1989-1990, Inst. de Geociencias, CEPAS, USP. p. 61-82 .

KRUCK, W. (1992) Interpretation of satelite data with special regard to Hydrogeoloy. Hydrogeologie, n. 1-2, p. 113-117.

KUMER, K.; RACIAT, D.S.; JOSHI, R. (1997) Chemistry of springwater in Almora, Central Himalaya, India. Environmental Geology, v. 31, n. 3/4, p. 169181.

LALONDE, V.P. (1983) Ground-water geochemistry in the Abitibi Volcanic Belt of Quebec. Amsterdam Journal of Geochemical Exploration, v. 19, p. 248-261.

LAVANDERO, R. (1987) Mapa de Yacimientos Metálicos y Aguas Minerales de la República de Cuba. Moscu, Editora Estatal. (Escala 1:250 000).

LLAMAS, M.R. (1992) Caracterización Hidrogeológica de las Aguas Minerales y Minero-medicinales. In: INSTITUTO GEOMINERO DE ESPAÑA Jornadas de Aguas Minerales y Mineromedicinales en España. Madrid, ITGME. p. 2,1-2,12.

LLOPIS LLADO, N. (1970) Fundamentos de Hidrogeología Cárstica. Madrid.Editorial Blume. 643 p.

LOVELL, J.S.; MAYER, W.T.; ATKINSON, D. (1983) Surface geochemistry at Rooselvelt Spring KGRA, Utah. Journal of Geochemical Exploration, v. 19, p. 148-159.

MACKAY, D.M. ; CHERRY, J.A (1989) Groundwater contamination: Pump and treat remediation. Environmental Science Technology v. 23, n..6, p 6578.

MANDEL, S. ; SHIFTON, Z.L. (1981) Groundwater Resources. London, Academic Press. $380 \mathrm{p}$.

MASON, B. (1960) Principios de Geoquímica. Barcelona Ediciones Omega S.A. $333 \mathrm{p}$. 
MATTHESS, G. (1982) The properties of groundwater. . New York. John Wiley \& Sons. 406 p.

MELIORIS, R. (1968) Manantiales de Aguas Minerales de Cuba. IN: CONFERENCIA CIENTÍFICO-TÉCNICA DE LA FACULTAD DE TECNOLOGÍA DE LA UNIVERSIDAD DE ORIENTE Santiago de Cuba. p. 1- 158.

MILNES, A G. (1985) Geology of Radwaste. Canada. John Wiley \& Sons, Inc., $753 \mathrm{p}$.

MORALES-JUBERIA, T.; OLAZAR, M.; ARANDES, I.M.; ZAFRA, P.; ANTIGUEDAD, I. ; BASAURI, F. (1987) Application of solute transport model under variable velocity conditions in a conduit flow aquifers: Olalde Karst System, Basque County, Spain. Environmental Geology, v. 30, n. 3/4, p. 346351.

MOURA, F. A . (1996) Estudo Geoestatístico da qualidades das águas subterrâneas do Litoral Paraibano. . Aquas Subterrâneas, ABAS. Resumo, n. 15 , p. $125-127$.

MOURÃO, B.M. (1997) A água mineral e as termas. São Paulo, Abinam. $269 p$.

NATIV, R.; HALLERAN, A . ; HUNLEY, A . (1997) Evidence of groundwater circulation in the borned-filled aquitard, Oak Ridge, Tennessee. Journal Association of Groundwater Scientists \& Enginners. July-August., v. 35, n..4, p. 647-659.

NAVARRO ALVARGONZÁLEZ, A (1992) Conceptos básicos de Hidrogeología. Jornadas de Aguas Minerales y Mineromedicinales en España.

In: INSTITUTO GEOMINERO DE ESPAÑA Jornadas de Aguas Minerales y Mineromedicinales en España. Madrid, ITGME. p. 1-9.

NUÑEZ JIMÉNEZ, A . (1970) Atlas Nacional de Cuba. Moscú. Editora Cartográfica No. 2 de la Dirección General de Geodesia y Cartografía adjunta al Consejo de Ministro de la URSS. $142 \mathrm{p}$.

OMS/FAO (1996) Comisión del Codex Alimentarius, Zurich, $22^{\circ}$ reunión. Alinorm 97/20. $54 \mathrm{p}$.

PEREZ HIPOLIT, J.; RODRIGUEZ, N. (1992) Exploración Orientativa de aguas minerales naturales "Peña AZUL". Camaguey, Informe de producción. Empresa Geólogo-Minera de Camaguey, Unión Geólogo Minera, MINBAS, Cuba. 48 p.

PÉREZ PEÑA, E. (1998) Interpretación Tectónico - Estructural de los datos geofísicos de la región Ciego de Ávilam-Camaguey-Las Tunas. Camaguey, Informe de producción. Empresa GeólogomMinera de Camaguey, Unión Geólogo Minera, MINBAS, Cuba. 149 p. 
PHI, UNESCO (1996) Mapa Hidrogeológico da América do Sul, CPRM, Brazilia. (Escala 1:5000000). 218 p.

PHILLIPS, F. M. ; BENTLEY, H, W ; DAVIS, S. N. ; ELMORE, D. ; SWANICK, G. B. (1985) Chlorine 36 dating of very old groundwater. 2. Milk River Aquifer, Alberta, Canada. Water Resources Research. Vol. 22 , No. 13, December. pp 2003-2016.

PINAGUA ESPEJEL, J.I. (1992) Las Aguas Minerales em Espana. In: INSTITUTO GEOMINERO DE ESPAÑA Jornadas de Aguas Minerales y Mineromedicinales en España. Madrid, ITGME. p. 3,3-3,9.

PINTO SERRANO, M. (1996) Importancia e Aplicações dos conceitos de Background e Baseline em Geoquímica Ambiental. Dep. de Geociencias, Univ. de Aveiro, Portugal. Palestra no Inst. de Geociencias, USP. São Paulo. 21 p.

PLOTNIKOV, N. A . (1962) Ressources en Eaux Souterraines: Classification et Methodes D'Evaluation. . París. Gauthier-Villars et $C^{i e} .378 p$.

POMEROL, CH. ; RICOUR, J. (1992) Terroirs et Thermalisme de France. París, Ediciones du BRGM. 288 p.

POWELL, J. (1985) Relation between groundwqter quality and mineralogy in the coal producing Norton Formation of Buchanan County, Virginia. USGS. Water-Supply Paper 2274. p. 6-21.

RAMBAUD, A . (1990) Les eaux conditionnées. París. FAO. 38 p.

REBOUZAS, A . (1996) Conferencias de la asignatura de post-grado Gestão de Aqüíferos. Instituto de Geociências, Universidade de São Paulo, Brasil.

RODRIGUEZ, F (1992) Informe sobre la evaluación de las aguas del Pozo Agustín 2 en El Azufre para su uso como minero-medicinal. Informe de producción. Empresa Geólogo-Minera de Camaguey, Unión Geólogo Minera, MINBAS, Cuba. $26 \mathrm{p}$.

RODRIGUEZ, F. (1994) Evaluación de los pozos Veracruz y Paso de Lesca. Informe de producción. Empresa Geólogo-Minera de Camaguey, Unión Geólogo Minera, MINBAS, Cuba. 31 p.

RODRIGUEZ, F. ; CASCARET, A (1990) Prospección de aguas minerales de mesa "Chaparra". Informe de producción. Empresa Geólogo-Minera de Camaguey, Unión Geólogo Minera, MINBAS, Cuba. 87 p.

RODRIGUEZ, F. ; GARCÍA, M. (1994) Prospección Preliminar y Detallada de aguas minerales en el sector "Camalote". Municipio Guáimaro, provincia de Camaguey. Informe de producción. Empresa Geólogo-Minera de Camaguey, Unión Geólogo Minera, MINBAS, Cuba. 67 p. 
RODRIGUEZ, F.; GARCÍA, M. (1990) Informe final de prospección y exploración de aguas minerales naturales de mesa en el municipio Camaguey, sector Sabanilla. Informe de producción. Empresa Geólogo-Minera de Camaguey, Unión Geólogo Minera, MINBAS, Cuba. 55 p.

RODRIGUEZ, F., PADRÓN MARTÍN, M.; ESCALONA, N. (1996) Generalización Hidrogeológica de Ciego de Ávila, Camaguey y Las Tunas. Informe interno. EMP. Geólogo-Minera de Camaguey, Cuba. 52 p.

ROQUIN, J.E. ; ZEAGER, H. (1987) Improved anomaly selection by stastiscal estimation of background variation in required geochemical prospecting. Journal of Geochemical Exploration, v. 29, p. 342-356.

ROSE, A W.; WESDOWSKI, D. ; SMITH, A T. (1983) Ground-water geochemistry of uraniun and other elements, Monticelli Area, N.Y. Journal of Geochemical Exploration, v. 19, p. 112-121.

ROSENTHAL, E; WEINBERGER, G.; KRONFELD, J. (1999) Ground Water Salinization Caused by Residual Neogene and Pliocene Sea Water-An Example from the Judea Group Aquifer, Southern Israel. GROUND WATER Vol,37. No.2 March-April .

ROSLER, H.J. ; LANGE, H. (1972) Geochemical Tables. New York, Elsevier Publishing Company. $167 \mathrm{p}$.

SABINE, P.A. (1981) Carte géologique d'environement en Grande Bretagne. Hydrogeologie, n. 2, p. 169-178.

SARRAT-REYNAULD, J. ( 1989 ) Étude isotopique des eaux souterraines de la région de Koula Nossombougu (Malí). Hydrogeologie, n. 3, p. 179-187.

SCHEYTT, T. (1997) Seasonal variation in groundwater chemistry near Lake Belaw, Schleswig-Holstein, Northern Germany. Hydrogeology Journal, v. 5, n.. 2, p. 232-243.

SANTOS, A .C. (1996) Caracterização hidrogeológica e hidrogeoquímica do aquífero fissural da região do Alto Paeju, PE. Águas Subterrâneas, ABAS. Resumo, n. 15 , p. 133-134.

SCHOELLER, H. (1955) Arid zone hydrology. Recent developments. UNESCO, Paris. $125 \mathrm{p}$.

SCHOELLER, H. (1962) Hydrogeologie. Vol. Il. Paris. Societé des Editions.TECHNIP $443 \mathrm{p}$.

SCHUARTZ, S. (1994) Fundamentos da Hidrogeoquímica. Metodologías de Evaluación de Sistemas Aquíferos. IN: $2^{\circ}$ CONGRESSO LATINOAMERICANO DE HIDROLOGIA SUBTERRÂNEA. Santiago de Chile. ALHSUD. $35 p$. 
SCHUMANN, W.

(1974) Rocas y minerales. Ediciones Omega, S.A.

Barcelona. $226 \mathrm{p}$.

SELINUS, S. ; ESBENSEN, K. ( 1995 ) Separating Anthropogenic from Natural Anomalies in Environmental Geochemistry. Journal of Geochemical Exploration, v. 55, p. 221-232.

SHINOBE, A ; SRASEK, A (1997) Drenagem ácida e seu impacto ambiental. Revista Brasil Mineral , n. 156.

SILVA PEREIRA CABRAL, J.J. (1995) Simulação computacional de águas subterrâneas utilizando métodos de elementos de contornos. Águas Subterrâneas, ABAS. Resumo, n. 15 , p. 133-134.

SIMÕES, RENÉ A .P. (1997) Análise do mercado de águas minerais e suas tendências. Revista Engarrafador Moderno. Ediçào especial Água Mineral, novembro. Aden Editora e Comunicações Ltda, p. 13-26.

SIMPSON, R.R. (1991) Multi-purpose geochemical mapping. Journal of Geochemical Exploration , v. 49, p. 222-231..

SOULÉ, J.C. (1990) Circulations Profondes en Milieu Granítique: Eaux Sulfurées des Pyrénées. París. Hydrogeologie, n. 4, p. 297-299.

SPEIRAN, G.K. ; AUCOTT, W.R. (1994) Effects of Sediments depositional Environment and Ground Water flow on the Quality and Geochemistry of Water in Aquifers in sediments of Cretaceus Age in the Coastal Plain of South Caroline. US Geologycal Survey. Water Supply Paper, n. 2416, p. 14-18.

SPIRIDONOV, V.P. ; LOPATIN, A .A . (1973) Tratamiento Matemático de Datos Físico-Químicos. Moscú.Editorial MIR, p. 205.

SRASEK, A (1998) Remediation of inorganic contamination. Example of lead. Notas do curso, IGc, USP, São Paulo.

SRINIVOSO ROS, Y.; REDDY, T.V.K. ; NAYUDA, P.T. (1997) Groundwater quality in the Niva River Basin, Chittoor District, Andhra Pradesh, India. Environment. Geology, v. 32, p. 325-334.

STRUCKMEIER, W.F. ; MARGAT, J. ( 1989 ) Les cartes hidrogéologiques au service du développenent économique et social. Hydrogeologie, n. 4, p. 293296.

STRUCKMEIER, W.F. ; KRAMPE, K.D.W. (1992) Developments in hydrogeological mapping. Hydrogeologie, n. 1-2, p. 105-111.

SUELY SCHUARTZ, MS. (1994) Metodologias de Evaluación de Sistemas Aquíferos. CURSO PRÉ-CONGRESSO. $2^{\circ}$ CONGRESSO LATINOAMERICANO DE HIDROLOGÍA SUBTERRÁNEA. Chile. 
SZIKSZAY, M. ; TEISSEDRE, J-M. (1979) Fontes do Campo de Jordão, Brazil. Boletim IG-USP v. 10, p. 1-10.

SZIKSZAY, M. (1993) Geoquímica das Águas. Boletim IG-USP. Série Didática No. 5. São Paulo. 165 p.

TANIGUSHI, T. ; FILLION, E. (1996) Numerical Experiment for 3-Dimensional Flow Analysis in Fractured Rock With Porous Matrix. London. Advanced in Water Resources v. 19, n. 2, p. 97-107.

TODD, D.K. (1960) Ground Water Hydrology. 2 ed. John Wiley. New York. $300 \mathrm{p}$.

VALDÉS GONZÁLEZ, J.A (1976) Generalidades hidrogeológicas de la zona metamórfica de llha da Juventude. IN: I SEMINARIO NACIONAL DE INVESTIGACIONES APLICADAS. LA HABANA. $15 \mathrm{p}$.

VALDÉS GONZÁLEZ, J.A (1977) Distribución del ión fluor en Isla de Pinos. Revista El Constructor, Isla de Pinos, Cuba. $8 p$

VALDÉS GONZÁLEZ, J.A (1985) Los ríos de la parte norte de Isla de la Juventud como criterios evaluativos del drenaje de las aguas subterráneas.

Voluntad Hidráulica, n.78, p. 23-28.

VALDÉS GONZÁLEZ, J.A (1990) A necessary approach to the assessment of pumping groundwater resource in coastal areas. IN: INTERNATIONAL SYMPOSIUM ON GROUNDWATER MONITORING AND MANAGEMENT, DRESDEN, GERMANY. $22 \mathrm{p}$.

VALDÉS GONZÁLEZ, J.A .(a) (1991) Rescate de fuentes tradicionales de la província de Ciudad de La Habana. Informe Interno. Unión de Empresas Geólogo-Minera, MINBAS. La Habana. 45 p.

VALDÉS GONZÁLEZ, J.A.(b)(1991) Evaluación de los recursos Santa María del Rosario, C.H. Informe interno de producción. Archivos ONRM, Cuba. 40 p.

VALDÉS GONZÁLEZ, J. A; SIMANKE DE SOUZA, J.C. (1996) Análise Geostatística-Poços Tubulares em São José dos Campos-SP. Seminário da disciplina Geostatística Aplicada. I.G. USP. São Paulo. 15 p.

VALDÉS GONZÁLEZ, J.A ; KIMMELMAN E SILVA, A . A (a)(no prelo) Evaluación hidrogeoquímica de las aguas subterráneas en las zonas de granitoides de Cuba Centro-Oriental. Resultados comparativos com otras zonas similares continentales.

VALDÉS GONZÁLEZ, J.A ; KIMMELMANN E SILVA, A A .(b) (no prelo) Mineral waters in Cuba Centro-Oriental granodioritic zone. Some criteria about the prospection and explotaition of its resources processing the existing data base. 
VALDÉS GONZÁLEZ, J.A ; KIMMELMANN E SILVA, A A (c) (1998) Algunas consideraciones sobre el manejo de aquíferos de aguas minerales naturales y medicinales. in: Simposio Internacional sobre el Manejo de Recursos Hídricos, 4-9. 10. 1998, Gramado, R.S. Anais eletrônicos. 10p.

VALDÉS GONZÁLEZ, J.A ; KIMMELMANN E SILVA, A A (2000) Hydrogeochemical approach on highly mineralized groundwaters in Central Cuba. In: $31^{\text {st }}$ International Geological Congress, 6-17.08.2000, Rio de Janeiro, Brazil. CD-ROM Abstracts Volume.

VUILLERMENOT, P. ; TOULHOAT, P. (1992) Évolution chimique des eaux de la partie orientale du bassin de Lodive ( Hérault, France). Hydrogeologie, n. 3 , p. $173-186$.

WANFUNG, Z.; WHEATER, H.S. ; JOHNSON, P.M. (1997) State of art of modelling two-phase flow in fractured rocks. Environment Geology v. 31, n. $3 / 4$, p. $201-218$.

WATERLOO HYDROGEOLOGIC SOFTWARE (1998) AquaChem User's Manual. Waterloo Hydrologic Inc, Canada. 150 p.

WEBB, C. (1994) Geochemical mapping. Handbook of Exploration Geochemistry, $432 \mathrm{p}$.

WHITMORE, T.J. ; CHANG HUNG, M. (1997) Utilização da análise de agrupamento na caracterização hidrogeoquímica. In: VII Simpósium de Quantificação em Geociências. Boletim de Resumos Expandidos. IGCE/UNESP, Río Claro, Brazil.

ZEKTSER, I.S. ; DZHAMALOV, R.G. (1988) Role of Ground Water in the Hydrological Cycle and in Continental Water Balance. IHP III Project 2.3. Technical Documents in Hydrology. UNESCO, Paris. $133 p$

Zoller, U.(1994) Groundwater contamination and control. New York, M. Dekker, Inc. 712 p. 


\section{ANEXO I}

NORMAS CUBANAS PARA AS ÁGUAS MINERAIS

(93-01-218, 1995) 
NORUA CUBBANA

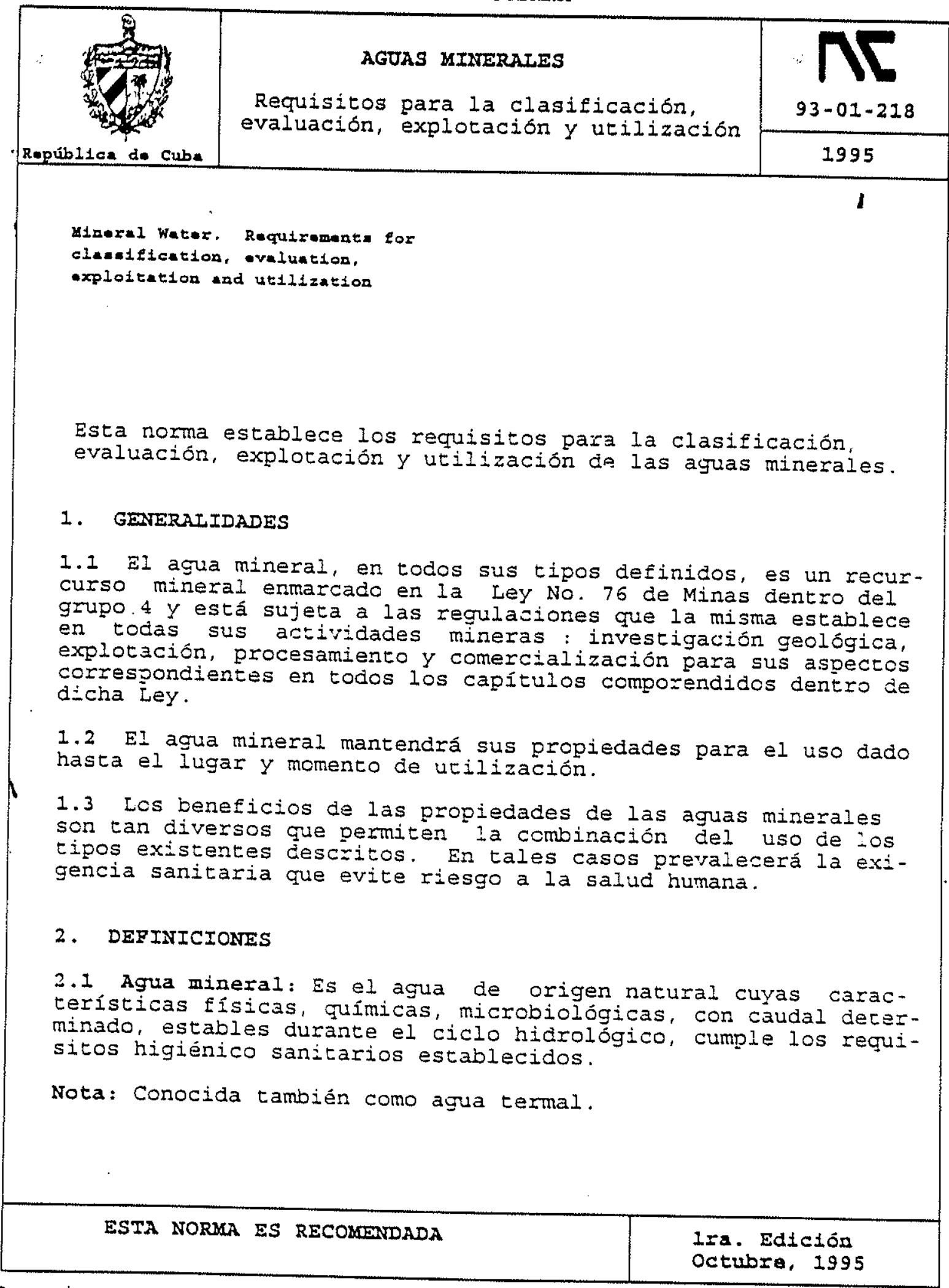

Descriptores: Agua Mineral; Clastelcacion, Estimaclon, 0t111zacion 


\section{CLASIBICACION}

Las aguas minerales se clasifican según sus usos en diferentes
tipos:

- Mineral natural

- Mineral medicinal

- Mineral termal

- Mineral industrial

3.1 Los requisitos de estas aguas son:

\section{1 .1 Mineral natural}

Agua que se diferencia claramente de la potable y que proviene directamente de fuentes naturales o perforadas de aguas proviene neas procedentes de rocas acuiferas. Contiene determinadas sales minerales y $/ 0$ oligoelementos para el metabolismo humano con utros constituyentes necesarios tura constantes, ton una composición, caudal y temperanes naturales. Esta agua es cuenta los ciclos de las fluctuaciozan la pureza bacterioló es obtenida en condiciones que garanti-

\section{1 .2 Mineral medicinal}

Agua mineral que por su compcsición y caracteristicas propias puede ser utilizada con fines teracéuticas, desce el área de emergencia hasca el lugar de utilizacibn, dada sus propiedades curatites; por experiencia local: te ensayos cliricos local; por estudios correspondientes o medianriencia médica comprobada, as cón de procesos especíticos de expeda, sus_efectos beneficiosos para conservar, caso de ser envasa-

\section{1 .3 Mineral termal}

Agua mineral cuya temperatura de surgencia debe ser supericr al menos en 4 grados centigrados, a la media anual ambiental del lugar donde emergen, permitiendo utilizar su acción calorifica.

\subsubsection{Mineral industrial}

Agua mineral que por su composición (cualitativa y cuantitativa) permite un aprovechamiento racional de los minerales que contiene.

\section{REQUISITOS}

\subsection{Requisitos cuantitativos}

Estos se refieren a los tres aspectos fundamentales de su distinción: la mineralización, los componentes bioactivos y la tempera-
tura. 


\subsubsection{Mineralizacion} 1. Baja mineralfzaclón: Las que tengan menor de $0,2 \mathrm{~g} / \mathrm{L}$ de sólidos
totales. 2. Media mineralización: Las que estén entre 0,2 y $1,0 \mathrm{~g} / \mathrm{L}$ y tablecidas en 4.1.2.

3. Alta mizeralización: Las que tengan mayor que $1,0 \mathrm{~g} / \mathrm{L}$.

\subsubsection{Componentes bioactivos}

$\begin{array}{llrl}\mathrm{H}_{2} \mathrm{~S} & 2 & 1,0 & \mathrm{mg} / \mathrm{L} \\ \mathrm{CO}_{2} & 2 & 250,0 & \mathrm{mg} / \mathrm{L} \\ \mathrm{Li} & 2 & 1,0 \mathrm{mg} / \mathrm{L} \\ \mathrm{Sr} & 2 & 20,0 \mathrm{mg} / \mathrm{L} \\ \mathrm{Ba} & 2 & 5,0 \mathrm{mg} / \mathrm{L} \\ \mathrm{Ze}+2 & 2 & 5,0 & \mathrm{mg} / \mathrm{L} \\ \mathrm{Br} & 2 & 4,0 \mathrm{mg} / \mathrm{L} \\ \mathrm{I} & 2 & 1,0 \mathrm{mg} / \mathrm{L} \\ \mathrm{AS} & 2 & 0,2<\mathrm{mg} / \mathrm{L} \\ \mathrm{E} & 2 & 1,0<2,0 \mathrm{mg} / \mathrm{L} \\ \mathrm{H}_{3} \mathrm{BO}_{3} & 2 & 4,0 \mathrm{mg} / \mathrm{L} \\ \mathrm{H}_{2} \mathrm{SiO}_{3} & 2 & 50,0 \mathrm{mg} / \mathrm{L} \\ \mathrm{Rn} & 2 & 1,82 \mathrm{nCi} / \mathrm{L}\end{array}$

\section{1 .3 Temperatura}

hipotermales < 4 grados a la temperatura media anual mesotermales - a la temperatura media anual

hipertermales > en 4 grados a la temperatura media anual

NOTAS

1. Los refericios componentes que estén regulados por las nomas cubanas de potabilidad (NC 93-02:85) no podrán utilizaxse como bebida si estas aguas no se avalan para este uso por las aucoridades sanitarias pertinentes o se dosifican bajo control médico directo en las instalaciones en que se apliquen. Los microcompcnentes gie se encuentran en este caso son: $\mathrm{Sr}, \mathrm{Ba}, \mathrm{Fe}+2$, As, $\mathrm{Rn}$ y $\mathrm{H}_{3} \mathrm{BO}$, (Loratos).

2. Otros microcomponentes que pueden beneficiar al bienestar humano $y$ por lo tanto, incluirse en este grupo, serán añadidos en la medica que la experiencia cientrfica nacional o internacional 10 declare y defina los límites de su acción.

3. Existen aguas minerales que no cumplen con los requisitos de componentes bioactivos, pero su acción combinada brinda caracter terapeutico, los cuales deberán estar avalados por estudios clini$\cos y$ datos estadisticos de su eficacia. 
NC $93-01-218: 95$

\subsection{Requisitos microbiológicos}

4.2.1 Las aguas minerales natural y medicinal deberán cumplir con los siguientes requisitos:

Conteo total de microorganismos heterótrofos

$\begin{aligned} & 100 \mathrm{UEC} / \mathrm{mL} \text { (mínimo) } \\ & 1000 \mathrm{UEC} / \mathrm{mL} \text { (máximo) } \\ &<\quad 2,2 \mathrm{NMP} / 100 \mathrm{~mL}(2) \\ &<\quad 2,2 \mathrm{NMP} / 100 \mathrm{~mL} \\ &<\quad 2,2 \mathrm{NMP} / 100 \mathrm{~mL}\end{aligned}$

Coliformes

Estreptococos fecales

Pseudomonas aeruginosa

Eacterias anaerobias formadoras de esporas y reductoras de sulfitos

ausencia

4.2.2 Agua mineral medicinal (uso externo)

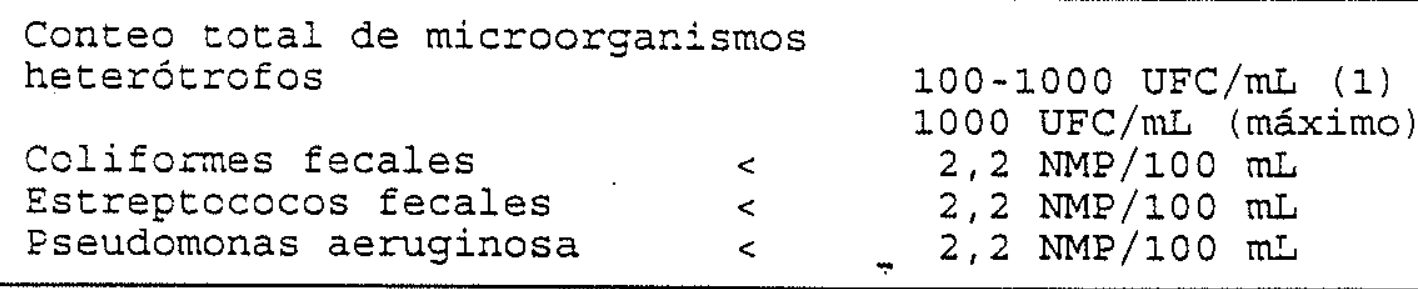

Se debe tener en cuenta 10 señalado en el epigrafe anterior para agua de bebida con la siguiente notación: (1), (2) y (3).

4.2.3 Todos lo análisis deberán realizarse dentro de las 24 horas de tomadas las muestras.

NOTAS :

(1) El número recomendado para el conteo de microorganismos heterótrofos está aún en discusión por diferentes paises debido a la microflora autóctona presente en estas aguas teniendo en cuenta los cambios estacionales. Este conteo se refiere al conteo total de bacterias a $37^{\circ} \mathrm{C}$ y $20-22^{\circ} \mathrm{C}$.

(2) De 5 muestras analizadas, una pudiera dar 2.2 de coliformes totales, en este caso deberá asegurarse que no sean coliformes fecales.

(3) En determinadas situaciones se deben investigar la presencia de microorganismos patógenos como Salmonella, Vibrio cholerae, Aeromonas, Shigella, Staphylococcus aereus, enterovirus y Giardia. En el caso de fuentes de agua que se van a emplear por primera vez es requisito indispensable el analizar en muestras obtenidas en periodos de lluvia y seca durante un ano, la presencia, mediante analisis cualitativo, de salmone11a, Aeromonas y Psoudomonas aeruginosa. 


\section{DENOMINACION}

La denominación del agua mineral está sujeta al predominio de sus componentes y propiedades, de modo que la mencion de un agua dada, identifica sus caracteristicas más sobresalientes. En este sentido, se establece: 1) La denominación primaria que expresa en sí su caracteristica básica y 2) la denominación secundaria que expresa otras caracteristicas especificas del agua.

\subsection{Denominación primaria}

Todos los tipos de agua mineral serán denominados, de acuerdo al orden mayoritario de aniones y cationes cuya concentración, expresada en por ciento miliequivalente (meq. $\frac{\%}{6}$ ), sobrepase $a: 20 \%$.

La presencia de los microcomponentes bioactivos permitirá: 1) secundar la denominación primera definida, de acuerdo también a las concentraciones mayoritarias, cuando se quiera hacer un agrupamiento general o 2) sustituir la denominación primaria, cuando se quiera hacer un agrupamiento especifico.

\subsection{Denominación secundaria}

Está dada para aquellas valoraciones que son resaltadas de acuerdo a consideraciones especificas para determinadas agrupaciones y cuyo campo de cetalle corresponde al campo de investigación y aplicación que se trate, entre otras

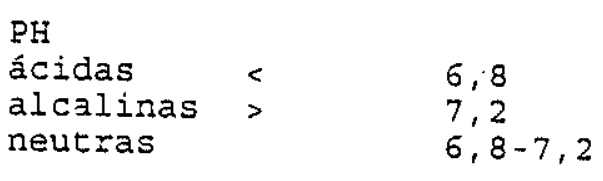

\section{REQUISITOS DE EVALUACION}

Para considerar un yacimiento de àga mineral preparado para iniciar el proceso inversionista de explotación, debe estar avalado por un estudio hidrogeológico que fundamente, como resultados básicos en el punto de emergencia y cumpliendo con las regulaciones de la información geológica existente, lo siguiente:

- La caracterización y demostración de la estabilidad de las propiedades físico-quimicas y bacteriológicas del agua mineral existente. Estos aspectos deben estar avalados por laboratorios acreditados que certifiquen el cumplimienco de las normas de muestreo y control de la calidad de las determinaciones realizadas.

Las especificaciones sanitarias y de calidad que deben cumplir los tipos de agua evaluados estarán regidas por la NC 84-24:1991
y 10 establecido en 4.2 .

- La valoración de los recursos de explotación correspondientes a la preservación de la calidad del agua determinada. 
- La argumentación de la(s) posible(s) utilizacion del agua estudiada, sea por 1) analogía con similares caractaristicas 0 2) experiencia existente.

- El establecimiento de la zona de protección sanitaria necesaria para el mantenimiento del caudal y calidad evaluados. Acompañara a esta información las recomendaciones de las medidas que ceberán comarse dentro de la zona establecida.

- Las especificaciones para las zonas y sus regulaciones estarán regidas por NC 93-01-209.

\section{REQUISITOS PARA LA EXPLOTACION Y UTILIZACION}

Un yacimiento de agua mineral está apto para la utiiización a que se destina si viene avalado por la documentación siguiente:

- Estudio Hidrogeológico con Reservas aprobadas for la autoridad minera.

- Estudio de factibilidad.

- Proyecto de explotación aprobado por la autoridad minera.

- Proyecto de procesamiento aprobado.

- Establecimiento de la zona de protección sanitaria real con la cerca perimetral (metálica a natural) por lo menos en la zona de restricción absoluta.

- Cumplimiento de las regulaciones y legalizaciones concernientes con la actividad minera para la explotación de este recurso contenidas en la Ley Minera de Cuba.

\section{REQUISITOS DURANTE LA EXPLOTACION}

\subsection{Control de la explotación}

- El agua mineral durante su explotación debe estar sometida a un control periódico minimo de dos veces por año en el lugar de captación $y$ en el punto de utilización también, cuando no coincidan. Los parámetros inestables serán determinados in situ.

- El control periódico referido de laboratorio y terreno debe comprender los parámetros siguientes:

\section{Caudal}

Niveles estáticos y dinámicos

Propiedades físicas del agua

Composición quimica de macro y microcomponentes

Requisicos microbiologicos - El control debe hacerse por entidad ajena al concesionario de la
instalación. 


\subsection{Regulactones durante el uso}

- El agua mineral no podra ser utilizada en cuestiones ajenas a su funcion evaluada.

- El agua mineral evaluada como un tipo dado de uso no podrá combinarse con otro tipo de agua si no reúne en sí misma las exigencias particulares dadas para cada tipo.

- Las responsabilidades a contraer con el estado por el concepto de la comercialización del agua mineral no pueden ser evadidas por detrimento de la calificación evaluada de este recurso.

- Las exigencias especificas dentro del sistema de explotación de cada tipo de agua vendrán dadas por las correspondientes normas vigentes.

- El agua mineral no deberá ser sometida a ningún tratamiento que modifique alguna de las propiedades que ameritan su valor especifico.

\section{REPERENCIAS}

\section{NORYAS CUBANAS}

NC $84-24: 91$

Bebidas no alcohólicas. Agua de bebida envasada. Especificaciones.

NC 93-02:85 Higiene comunal. Aqua potable. Requisitos sanitarios y muestreo.

NC 9j-09:85 Higiene comunal. Balnearios Minero-Medicinales. Requisitos higiénico sanitarios.

NC 93-11:86 Higiene comunal. Fuentes de abastecimiento de agua.

NC 93-01-209:90 Sistema de Normas de protección del Medio Ambiente. Hidrosfera. procedimiento de calculo para la determinación de la zona de protección sanitaria.

\section{NORMAS INTERNACIONALES}

ISO $6107-8: 93$

CODEX: STAN 108-1981.

Water Quality Vocabulary

Norma CODEx para las aguas minerales. Norma Regional Europea.

\section{NORMAS EXTRANJERAS}

CSN 86800:81 Aguas medicinales naturales $Y$ aguas minerales naturales. 


\section{BIBLIOGRAFIA CONSULTADA}

Francia Decreto No. 56-284 del 9 de marzo de 1956.

Francia Decreto No. 57-404 del 28 de marzo de 91957.

España Armijo, M. y San Martin, J. 1994 Compendio de Hidrología
Médica.

España Armijo, M. Y San Martín, J. 1984 La salud por las aguas
termales, Editorial ESAF.

España Baeza J. (1992) Análisis y coordinación entre Ley de Mi.. nas y la reglamentación técnico sanitaria de las aguas
EE.LU
Fricke, M. (1994) SEA Resort curative and natural minoral water potencial of Irak Sith News.
Cuba
Japón
Ley No. 76 de Minas, La Habera 1994.
Yuhara, $x$. Utilization of thermal energy of Hot spring in Japan. 7 Giornale Mondiail del Termalismo, verona,
Itaila Decreco Legislativo 25 gennaio 1992, N 105 Attauzione della Diretiva $80 / 777 / C E$ alla urilizazione e alla commercializ zazione delle acque minerali naturali. Supplemento ordinario
G. U. n. 39 del 17.2.1992. 


\section{ANEXO II \\ GENERALIDADES SOBRE A MEDICINALIDADE DAS ÁGUAS}

MINERAIS 


\section{A CURA HIDROTERMAL}

\section{Antecedentes gerais :}

-Foi um tratamento descoberto e aplicado pelo homem desde tempos remotos -A água constitui o $60 \%$ do peso do corpo humano

-Tudo os processos e funções do organismo humano tem relação com a água

\section{MECANISMOS DE AÇÃO}

1-Mecánicos

1.1- Temperatura ( vaso dilatador, relaxamento, excitabilidade )

1.2- Densidade ( propiciar movimento muscular, flutuabilidade ( $90 \%$ peso )

2-Bioquímicos

\section{ABSORÇÃO}

1- Oral ( aproveita o máximo em bebidas e inalações )

2- Tópico ( aproveita-se um \% menor e em especial maior para SH2 , CO2 e Rn )

3- Biomecánicos ( resposta defensiva neurohormonal do organismo )

4- Psíquico (Efeito Placebo que e uma ação sugestiva comum a outros medicamentos, favorecedora até um $30 \%$ da efetividade de um remédio )

\section{A AGUA COMO MEDICAMENTO}

\section{CONTRAINDICAÇÕES:}

-Afeções agudas em período de atividade

-Tuberculoses

-Câncer y processos tumulares malignos

- Hipertensão arterial grave, insuficiência cardíaca descompassada

-Cirroses e insuficiência hepática grave

Nefrites hipertensa e insuficiência renal grave

-Doenças mentais graves

\section{INDICAÇÕES E PARTICULARIDADES RECONHECIDAS DOS TIPOS HIDROQUÍMICOS PRINCIPAIS DAS ÁGUAS MINERAIS:}

\section{AGUAS CLORETADAS}

Estimulantes das funções celulares, trofismo tisular, atividade secretora e metabolismo de acordo a concentração de seus sais com respeito ao soro sangüíneo ( hipo, iso e hipertônicas )

\section{AÇÃO:}

Em bebidas, com mineralização baixa e com $\mathrm{SO} 4$ e $\mathrm{HCO}$, aceita-se por via oral e beneficia :

-Estimulação da secreção clorídrica e motilidade gástrica

-Facilita secreção biliar

-Aumenta a secreção e motilidade intestinal 1.2 Aplicações tópicas 
-Aumento do poder de defesa da pele e mucosas -Ações antiflogísticas

-Efeitos gerais de estimulação orgânica

-Efeito ligeiramente anti-séptico no casos de águas hipertônicas

Ações mais direitas nelas afeções das mucosas do aparato respiratório, digestivo e genital feminino.

\section{INDICAÇÕES:}

Por tudo esto, aplica-se em :

-Recuperação de intervenções quirurgicas do aparato locomotor -Afeções reumáticas crônicas

Processos crônicos de vias respiratório e aparato genital feminino -Estado de debilidade orgânica

- Capacidade reaccional defensiva reduzida nela infância

\section{CONTRA-INDICACOES:}

-Gastrites hipersecretora

-Processos ulcerosos do aparato digestivo

-Enterites, colites, cardiopatias e afeções onde é conveniente reduzir ingestão de

\section{AGUAS BICARBONATADAS ( CALCICAS e SODICAS )}

\section{AÇÃo:}

Antes do café da manha são neutralizadoras da acidez gástrica. No intestino, o seu caracter alcalino favorece a ação dos fermentos pancreaticos e poder saponificante da bílis.

\section{INDICAÇÕES:}

-Doenças do aparato digestivo

-Alterações hepáticas

-Transtornos metabólicos e afeções das vias urinarias

-Afeções crônicas intestinais com diarrélas

-Processos hepáticos

\section{CONTRAINDICAÇÕES:}

-Hipertensão grave e insuficiência renal ( $\mathrm{HCO} 3 \mathrm{Na}$ de alta mineralização )

-Colites atônicas, entretimento pertinaz, calculasses fosfatica ( $\mathrm{HCO} 3$

\section{AGUAS SULFATADAS ( CALCICAS Y MAGNESIANAS )}

\section{AÇÃO:}

Aquelas com alta mineralização tem efeito laxante e, por sua forte hipertonia, possibilita a saída de bilis do intestino. Por isso, também faz-lhe ser irritante e modificadora do equilíbrio coloidal do epitelio, em especial a zona ileocecal.

\section{INDICAÇÕES:}

-Ressecamento e certas colecistopatias 
-Facilitamento de diureses

-Processos dispépticos, hepatopatias e distúrbios metabólicos ( hiperuricemias, determinados quadros de obesidade )

\section{CONTRAINDICAÇÕES:}

-Aquelas que derivam-se da medicação laxante

-Processos ulcerosos do aparato digestivo

\section{CARBOGASEOSAS ou CARBONICAS ( CO2 libre $>250 \mathrm{mg} / \mathrm{l}$ )}

Ligeiramente excitante da mucosa do revestimento do aparato digestivo e atenuante da sensibilidade gástrica. Estimulante da secreção do jugo gástrico.

\section{Ação:}

-Diurética por ingestão de grandes quantidades em jejum.

\section{INDICAÇÕES:}

-Estimulante do apetite

-Incremento da secreção do $\mathrm{ClH}$ e tempo do esvaziamento gástrico

\section{CONTRAINDICAÇÕES:}

-Hipercloridrias -Dilatação gástrica -Ptosis visceral

\section{AGUAS SULFÚREAS, SULFURADAS OU SULFUROSAS}

\section{$\left\{\mathrm{S} 2, \mathrm{SH}^{\prime}, \mathrm{S}^{\circ}\right.$ e SH2 $>1 \mathrm{mg} / \mathrm{l}$}

( $P$ ara que $\mathrm{SH} 2$ passe a $\mathrm{S}^{\circ}$ deve haver $\mathrm{pH}$ muito alto )

\section{Ação:}

Comportamento antitoxico, dessensibilizante, estimulante metabólico, melhoramento da permeabilidade vascular. Destacada seletividade pela mucosa do arvore respiratório e pela estrutura articular, em especial do tecido cartilaginoso.

As ações locais e gerais depende da via de seu aplicação : bebidas, inalações e banhos.

\section{AGUAS FERRUGINOSAS y FERRO-ARSENIACAIS ( $\mathrm{Fe}>5,0 \mathrm{mg} / \mathrm{l}$; As $>0,2 \mathrm{mg} / \mathrm{l}$ )}

\section{Ação:}

Fez fácil absorção em alta diluição, por isso deve-se beber ao pé do manancial para ter segurança de seu eficácia

Absorve-se pelas células da mucosa intestinal, passa a sangue e dai aos pontos de armazenamento. Intervém nela regeneração de hematites, formação de hemoglobina e enzimas oxidantes, produzindo, alem do estimulo, uma mehioria do trofismo e do estado geral.

O arsênico participa do estimulo da medula osea, amortecedor da atividade tiróide e as funções catabolicas, pelo que considera-se excitrotrofica e estimulante da nutrição em geral. 


\section{AGUAS RADIOATIVAS}

AÇÃO:

A emanação do gás Radon concede um efeito ionizante. Sua ação é temporal e breve ( 3,8 dias) o que face precisar bebe-la ao pé do manancial.

Para causar seu efeito terapêutico deve ter ao menos $2,0 \mathrm{nCi} / \mathrm{l}$ nele ponto de saída. Temse estimado uma quantidade minima de $1,8 \mathrm{nCi} / \mathrm{l}$ ( 5 Unid. Mache) para que seja absorvido por todas vias preferentes : respiratórias , pele e digestão.

Tem preferencia por os tecidos mais sensiveis : hematopoyetico, gonadas e intestinos, e também sobre o sistema nervoso, fundamentando seu efeito sedante, analgésico, antiespamodico, decontracturante e regulador do tono vegetativo.

\section{INDICAÇÕES:}

Distonia vegetativa, processos álgidos reumáticos de evolução crônica, mialgias e neuralgias, ou asma bronquial e bronquites asmatiformes, a gota e a diatesis urica, dermatosis pruriginosas, algias pelvianas e processos congestivos crônicos ginecológicos.

\section{CONTRAINDICAÇÕES:}

As gerais.

\section{PARTICIPAÇÃO DOS ELEMENTOS METALICOS}

Entre as principais funções destes elementos no organismo estão :

Como componente de proteínas :

Transportador de electrones --..--.--Cytochromas( Fe) e plastocyanina ( $\mathrm{Ca}$ )

Transportador/armazenagem $\mathrm{O}_{2}$-...-.-.-.-Hemoglobina ( $\mathrm{Fe}$ ) e hemocyanina ( $\mathrm{Cu}$ )

Transportador/armazenagem metais-----Ferritin ( $\mathrm{Fe}$ ) e ceruplasmina ( $\mathrm{Cu}$ )

Estrutu-Thermolysina ( Ca ) e insulina ( $\mathrm{Zn}$ )

Cofator---.--Concanavalina $A(\mathrm{Mn}, \mathrm{Ca})$

Detoxificacao---Metallothioneinas $(\mathrm{Cd}, \mathrm{Hg}, \mathrm{Ag}$ )

Como componente de enzimas nos processos:

Reductases e oxidasses ( $\mathrm{Cu}, \mathrm{Fe}, \mathrm{Mn}, \mathrm{Mo}, \mathrm{Zn}$ )

Quinasse ( $M n, M g, K$ ) e polymerases ( $M g, M n, Z n$ )

Phosphotases ( $\mathrm{Na}, \mathrm{K}, \mathrm{Ca}, \mathrm{Mg}, \mathrm{Zn}$ ) e peptidases ( $\mathrm{Zn}, \mathrm{Ca}$ )

Hidro-Lyases ( $\mathrm{Ca}, \mathrm{Fe}, \mathrm{Mn}, \mathrm{Zn}$ )

Mutases ( $\mathrm{Mg}, \mathrm{Co}$ )

Carboxylases ( $M g, M n, Z n$ ) e sinthetases ( Ca, Co, Mg, Mn, K)

\section{Alguns aspetos da toxicidade dos metais:}

Neurotoxicidade $\mathrm{Hg}, \mathrm{Pb}, \mathrm{Al}$

Toxicidade renal $\mathrm{U}, \mathrm{Cd}, \mathrm{Pb}, \mathrm{Hg}$ 